\title{
Ideologia i przywództwo we współczesnych Chinach
}

Redakcja naukowa

Daniel Kawa 


\author{
Seria \\ Biblioteka Azji i Pacyfiku \\ Redaktor Serii \\ Joanna Marszałek-Kawa
}

Sekretarz Serii

Bartosz Ptotka

Rada Serii

Kamal M. Abdulla (Azerbejdżan), Daulet L. Baideldinov (Kazachstan), Marceli Burdelski (Gdańsk), He Yaomin (Chiny),

Hassan A. Jamsheer (Łódź), Vasyl Marchuk (Ukraina), Joanna Marszałek-Kawa (Toruń), Miao Huashou (Chiny), Vladimir I. Nifadiev (Kirgistan), Ewa Oziewicz (Gdańsk), Zdzisław Puślecki (Poznań), Akmal Saidov (Uzbekistan),

Grażyna Strnad (Kraków), Peter Vorel (Czechy)

Recenzenci tomu

prof. dr hab. Marian Kowalewski

prof. dr hab. Maciej Szczurowski

Redaktor prowadzący: Pawet Jaroniak

Redakcja techniczna: Ryszard Kurasz

Korekta: Zespót

Projekt okładki: Krzysztof Galus

(c) Copyright by Wydawnictwo Adam Marszałek

Wszystkie prawa zastrzeżone. Książka, którą nabyłeś, jest dziełem twórcy i wydawcy. Żadna jej część nie może być reprodukowana jakimkolwiek sposobem - mechanicznie, elektronicznie, drogą fotokopii itp. - bez pisemnego zezwolenia wydawcy. Jeśli cytujesz fragmenty tej książki, nie zmieniaj ich treści i koniecznie zaznacz, czyje to dzieło

Toruń 2020

ISBN 978-83-8180-312-0

Wydawnictwo prowadzi sprzedaż wysyłkową:

tel./fax 566485070 , marketing@marszalek.com.pl

Wydawnictwo Adam Marszałek, ul. Lubicka 44, 87-100 Toruń

tel. 5666422 35, 5666081 60, e-mail: info@marszalek.com.pl, www.marszalek.com.pl

Drukarnia, ul. Warszawska 54, 87-148 Łysomice, tel. 566783478 


\section{Spis treści}

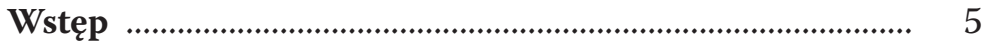

\section{Zbigniew Wiktor}

Marksizm i konfucjanizm w ideologii Komunistycznej

Partii Chin

\section{Jerzy Sielski}

Komunistyczna Partia Chin i jej przywódcy

\section{Marian Tadeusz Mencel}

Chiny wobec decyzji traktatu wersalskiego -

Ruch 4 Maja 



\section{Wstęp}

Chiny to państwo obszarowo ogromne, szybko się rozwijające, z długą i ciekawą historią. To także kraj tajemniczy, budzący podziw, czasami wywołujący obawy, a nawet strach wielu przywódców państw. W ostatnich latach polityka chińska ulega poważnym zmianom. Stosowana dotychczas zasada ukrywania swego potencjału jest zastępowana koncepcją chińskiego marzenia autorstwa Xi Jinpinga, która oznacza wielkie odrodzenie narodu.

Przemiany ekonomiczne, społeczne, kulturowe i demograficzne zachodzące w ostatnich dziesięcioleciach prowadzą do znaczących zmian na mapie świata. Rośnie także liczba Chińczyków zarówno w Europie, jak i Polsce. W tej sytuacji potrzebna jest znajomość ich kultury, mentalności i postaw religijnych, aby uniknąć zjawiska zamkniętych enklaw i doprowadzić do jakiejś formy integracji kulturowej.

W moim przekonaniu każde opracowanie dotyczące współczesnych Chin i ich pozycji międzynarodowej musi uwzględniać wielki plan Nowego Jedwabnego Szlaku, który swym zasięgiem ma objąć 65 państw zamieszkiwanych przez $60 \%$ populacji świata. Zdaniem niektórych uczonych, reaktywując ideę szlaku łączącego Wschód z Zachodem, Chiny zamierzają stanąć na czele globalizacji przyszłości. Projekt ten ma polegać na zbudowaniu infrastruktury ekonomicznej i handlowej na osi dwóch szlaków: lądowego i morskiego. Prace nad jego realizacją już trwają. Pekin szczególnie chętnie wspiera państwa o słabej strukturze. Chodzi o stworzenie korzystnych dla Chin warunków do ekspansji ekonomicznej. Realizację tych celów ułatwiają ich ogromny potencjał ekonomiczny i duże rezerwy finansowe. 
Chińskie aspiracje do udziału w decydowaniu o współczesnym świecie opisała grupa trzynastu uczonych z Uniwersytetu Ludowego w Pekinie (Renmin University of China), jednej z najważniejszych uczelni Chin. Swoje poglądy zawarli oni w pracy zatytułowanej Pewność siebie i świadomość Chin w globalnym zarządzaniu ${ }^{1}$. We wstępie autorstwa Jin Nuo, sekretarza komitetu partyjnego Uniwersytetu Ludowego ChRL, przewodniczącego Rady Dyrektorów Narodowej Akademii Rozwoju i Strategii, pada stwierdzenie, że Chiny wnoszą wielki wkład w rozwój ludzkości i w coraz większym stopniu przejawia się to w poziomie globalnego zarządzania. Jego zdaniem społeczność międzynarodowa pragnie usłyszeć głos Chin i poznać metody rozwiązywania problemów. Nieodzowność udziału Chin w globalnym zarządzaniu wynika z kulturowego doświadczenia Chin. Struktura globalnego zarządzania zależy od stosunku sił międzynarodowych. Stwierdza on wprost, że Chiny muszą stać się światowym liderem i brać aktywny udział w globalnym zarządzaniu. W zakończeniu autorzy stwierdzają, że w ostatnich latach międzynarodowe prawo głosu przeszło po cichu z Zachodu do Chin.

Prezentowana praca, która ukazuje się w serii Biblioteka Azji i Pacyfiku, składa się z trzech tekstów, które dotyczą dwóch odrębnych zagadnień. Pierwsze dwa skupiają swoją uwagę na współczesności ze szczególnym uwzględnieniem roli Komunistycznej Partii Chin. Ostatni zaś jest przyczynkiem do XX-wiecznej historii Chin.

Autorem artykułu pt. Marksizm i konfucjanizm w ideologii Komunistycznej Partii Chin jest znawca Chin profesor Zbigniew Wiktor z Uniwersytetu Wrocławskiego. Podkreśla on, że odmienność polityczno-ustrojowa Chińskiej Republiki Ludowej nie przeszkodziła temu państwu znaleźć korzystnych dla

1 Jin Nuo et al., Pewność siebie i samoświadomość Chin w globalnym zarzadzaniu, Toruń 2019, ss. 286. 
siebie form kooperacji z gospodarkami innych państw. Jednak podstawowym zadaniem, jakie postawił sobie autor, jest analiza różnic i związków między marksizmem a konfucjanizmem w ideologii Komunistycznej Partii Chin. Swój wywód rozpoczyna od prezentacji genezy konfucjanizmu i jego dalszych dziejów, a następnie opisuje konfucjanizm jako religię i podstawę ideologiczną cesarstwa chińskiego oraz osłabienie konfucjanizmu po upadku cesarstwa chińskiego. W dalszej części profesor Zbigniew Wiktor charakteryzuje walkę między konfucjanizmem a marksizmem. W jego przekonaniu KPCh nie obawia się konfucjanizmu, a nawet wykorzystuje jego treści i zasady w celu umocnienia i rozwoju chińskiej wersji socjalizmu.

Profesor Jerzy Sielski, autor kilku książek i artykułów o przywództwie, zarówno na przykładzie Polski², jak i Unii Europejskiej, swą część zatytułował „Komunistyczna Partia Chin i jej przywódcy". Stara się zaprezentować i zinterpretować podmioty mające największy wpływ na kierowanie Chinami. Z przeprowadzonej przez niego analizy wynika, że ani państwo, ani społeczeństwo nie są na tyle silne i zorganizowane, aby zasadniczo wpływać na władzę polityczną. Uważa, że w chińskim układzie politycznym najważniejszymi podmiotami są partia i jej przywódca.

Gdy na czele partii stawała silna osobowość, taka jak: Mao, Deng czy Xi, wówczas lider zyskiwał decydującą rolę.

Opracowanie kończy rozdział historyczny zatytułowany „Chiny wobec decyzji traktatu wersalskiego - Ruch 4 Maja” autorstwa Mariana Tadeusza Mencela z Gdańska. Warto w tym miejscu przypomnieć, że jest on autorem trzytomowego dzieła pt. Chińska Republika Ludowa jako wspótczesny podmiot środowiska międzynarodowego (t. I: Uwarunkowania, t. II: Wektory, t. III: Rozważania o rzeczywistości).

2 Np. J. Sielski, Teoretyczne aspekty przywództwa politycznego. Casus Polski, Toruń 2013. 
Marian Tadeusz Mencel podejmuje próbę ustalenia przyczyn powstania Ruchu 4 Maja i jego wpływu na ukształtowanie wewnętrznych stosunków społecznych i zmiany zachodzące na chińskiej scenie politycznej. Swe rozważania skoncentrował na syntetycznym ujęciu problematyki zmian zachodzących w środowisku międzynarodowym, a w szczególności polityki mocarstw wobec Chin oraz zjawiskach zachodzących w chińskim społeczeństwie, których Ruch 4 Maja był konsekwencją. Obszar analizy wyznaczają pola obejmujące ówczesne relacje międzynarodowe Chin, stosunki wewnętrzne i przemiany zachodzące wewnątrz Chin po obaleniu autorytaryzmu feudalnego oraz wzrost świadomości politycznej, zainteresowania socjalizmem, wzrastanie nacjonalizmu, odrzucenie tradycji konfucjańskiej i wreszcie powrót do wzorów konfucjańskich.

Mam nadzieję, że lektura wyżej wspomnianych tekstów przyniesie Czytelnikowi satysfakcję z poznania nowych, nieznanych mu jeszcze zagadnień i przyczyni się do rozbudzenia zainteresowania Chinami - państwem, którego rola w świecie ciągle rośnie. Miłej lektury!

Daniel Kawa 


\section{Zbigniew Wiktor}

Uniwersytet Wroclawski

\section{Marksizm i konfucjanizm w ideologii Komunistycznej Partii Chin}

\section{Uwagi wstępne}

Chińska Republika Ludowa jest dynamicznie rozwijającym się społeczeństwem, którego gospodarka od kilku lat jest traktowana przez znawców jako druga w świecie, a niektórzy uważają, że pod względem PKB przegoniła Stany Zjednoczone Ameryki i znajduje się na miejscu pierwszym. Rodzi to cały szereg następstw nie tylko ekonomicznych, także społecznych i politycznych. Dodatkowym elementem w tej dyskusji jest odmienność polityczno-ustrojowa ChRL, która jest państwem socjalistycznym i nie uznaje hegemonii kapitalistycznej Ameryki, choć w ostatnich wielu dziesiątkach lat potrafiła znaleźć korzystne dla siebie formy kooperacji z wielkimi gospodarkami świata w ramach pokojowego współistnienia. Obecnie potencjał gospodarczy i pozycja międzynarodowo-polityczna Chin są już tak wielkie, że bez państwa chińskiego nie można rozwiązać żadnego wielkiego problemu światowego ${ }^{1}$.

Chiny od tysięcy lat budziły zainteresowanie świata zachodniego głównie ze względu na wielkość państwa i narodu, ogrom bogactwa oraz odmienność cywilizacji chińskiej, promieniującej

1 Liczne aspekty tych zagadnień podejmowane są przez coroczne Międzynarodowe Kongresy Azjatyckie w Toruniu. Zob. w szczególności: J. Marszałek-Kawa (red.), Globalna potęga Chin. Czynniki i perspektywy, Toruń 2014, s. 5. 
na inne państwa i narody Azji i Dalekiego Wschodu. Chińczycy w ciągu liczących około 5 tys. lat własnych dziejów przeżywali okresy wzlotów i upadku, jednak dzięki wielkości tej cywilizacji potrafili wychodzić z opresji historycznych i budować nowe okresy świetności. Fundamentalną rolę w tym dziejowym procesie odgrywała chińska kultura i państwo chińskie, którego początki sięgają III tysiąclecia przed naszą erą. W odróżnieni od innych starożytnych cywilizacji potrafili utrzymać ciągłość własnej cywilizacji, rozwijając i dostosowując ją do nowych warunków rozwoju sił wytwórczych i zmieniającej się sytuacji międzynarodowej. Dużą rolę w rozwoju i umocnieniu państwa chińskiego i chińskiej cywilizacji odegrała odmienność gospodarczo-społeczna Chin, wyrażająca się w powstaniu tzw. azjatyckiego typu produkcji, będącego podstawą gospodarczo-społeczną scentralizowanego państwa chińskiego, zdolnego nie tylko do utrzymywania w ryzach własnego ludu, ale narzucającego także różne formy dominacji narodom sąsiadującym. O ogromnym potencjale finansowo-gospodarczym, organizacyjnym i logistycznym świadczą zachowane do dziś pozostałości wielkiego muru chińskiego, kanały, regulacje rzek, systemy nawodnień, budownictwo miejskie i kwitnąca kultura, której zachowane relikty zadziwiają współczesnych obserwatorów. Innym fenomenem chińskiej cywilizacji jest wczesne odejście społeczeństwa chińskiego od niewolnictwa, które przestało odgrywać dominującą rolę gospodarczą już w poł. I tysiąclecia przed nasza erą. Dużą rolę w tym procesie odegrała instytucja wiejskich (gminnych) wspólnot, skupiających wolnych chłopów, trudniących się pracą na roli, zróżnicowanych ekonomicznie, ale wolnych. Oznaczało to, że rozwój sił wytwórczych w rolnictwie był już na tak wysokim poziomie, że przestała być konkurencyjna siła robocza niewolników, wykonujących prace pod przymusem nie tylko ekonomicznym, ale także administracyjnym. Bardziej wydajna była praca wolnego chińskiego rolnika, który 
jednak znalazł się w ryzach kształtującego się ustroju feudalnego, który trwał z różnymi zmianami do końca cesarstwa na początku XX w. ${ }^{2}$

Ustrój feudalny trwający prawie 2,5 tys. lat miał liczne negatywne następstwa dla rozwoju Chin, szczególnie w ostatnich kilku wiekach. W warstwie kulturowej i religijnej dużą rolę w jego umacnianiu i petryfikacji odegrały konserwatywne nurty ideologiczne i wierzenia religijne, głównie konfucjanizm, taoizm, także importowany z Indii buddyzm. Szczególnie dużą rolę odegrał konfucjanizm, który przechodził przez liczne fazy rozwojowe i stworzył liczne szkoły i kierunki ideowo-teoretyczne. Jednak generalnie był najważniejszą podbudową ideowo-teoretyczną społeczeństwa chińskiego, zwłaszcza jego warstw wyższych - mandarynów, cesarstwa, ale także warstw niższych, głównie chłopów, stanowiących przez wieki główną masę narodu. Konfucjanizm był filozofią idealistyczną, główną oś porządku społecznego, przyrody wyznaczało „Niebo" jako amorficzne bóstwo, określające podstawowe relacje między ludźmi, którzy mieli odwieczne miejsce i role w porządku społecznym. Początkowo konfucjanizm był teorią filozoficzną, niemająca charakteru religijnego. Jednocześnie stanowił on podstawę do ważnego w kulturze chińskiej kultu przodków. Dopiero z czasem wykształciły się w nim pewne cechy doktryny religijnej, która wyznawana była przez setki milionów Chińczyków. Był to dodatkowy element konfucjanizmu, wyznaczający jego znaczenie w kształtowaniu świadomości społecznej Chińczyków3

2 Więcej na ten temat zob. fundamentalna praca autorów chińskich Bai Shouyi, Yang Zhao, Gong Shuduo, Wang Guilin, Lu Zhenxiang, Fang Linggui, Zhu Zhongyu, Guo Dajun, An Outline History of China, Beijing 2002, s. 16 i n.

3 Ibidem, s. 98 i n. Por. też: J. Pimpaneau, Chiny, kultura i tradycje, Warszawa 2001, w szczególności s. 168 i n. 
Konfucjanizm jako nurt ideowo-religijny pełnił przez wieki rolę konserwowania feudalnych stosunków społecznych i był ważną podporą ustroju cesarskich Chin, w szczególności jego warstwy urzędniczej - mandarynów. Z tego powodu pod koniec XIX w. i na początku XX w. był krytykowany i zwalczany przez postępowe nurty społeczne, które zawitały do Chin w tej epoce. Szczególnie mocno krytykował konfucjanizm i zwalczał go jako ruch konserwatywno-reakcyjny marksizm i ruch komunistyczny. Po obaleniu cesarstwa w $1911 \mathrm{r}$. i powstaniu republiki burżuazyjnej powstały nowe warunki dla szybkiego rozwoju kapitalizmu i towarzyszących mu nurtów ideowo-politycznych. Było to konsekwencją otwarcia się Chin na kapitał zagraniczny i narzucania hegemonii Chinom przez imperialistyczne państwa Zachodu i Japonię. Postępowe siły chińskie zrozumiały, że uratowanie niepodległości Chin i ich cywilizacji musi nastąpić przy pomocy postępu gospodarczego i społecznego rodem z Zachodu. Jednym z takich nurtów stał się ruch robotniczy, rozwój marksizmu i ruchu komunistycznego. W 1921 r. powstała Komunistyczna Partia Chin ${ }^{4}$.

KPCh od początku przyjęła kurs na dążenie do obalenia państwa burżuazyjno-obszarniczego i ustanowienia państwa socjalistycznego, w związku z tym przeciwnikiem ideowo-politycznym stał się także konfucjanizm. Wielką rolę w zwalczaniu konfucjanizmu odegrał jej wielki przywódca Mao Zedong, którego zasługi rewolucyjne i w zakresie tworzenia podstaw ustroju socjalistycznego są historyczne. Mao działał w okresie wielkich sprzeczności i walk klasowych. Prowadził nieustanne wojny partyzanckie, przeciwko Japończykom, także inne formy walki z chińską burżuazją. Po 1949 r. po powstaniu ChRL te sprzeczności przybrały charakter nie tylko klasowy, także międzynarodowo-państwowy i m.in. znalazły wyraz w wojnie

4 Więcej na ten temat zob. R. Terrill, Mao, biografia, Warszawa 2001, s. $78 \mathrm{i} \mathrm{n.}$ 
koreańskiej. Dalsza historia Chin ludowych do śmierci Mao to nieustanna walka polityczna na arenie wewnętrznej i międzynarodowej, która zaostrzała konfrontację ideową w Chinach między marksizmem i komunizmem a konfucjanizmem. Szczytowymi okresami tej walki był 1957 r. i kampania pod nazwą „Niech rozkwita sto kwiatów i rozwija się sto szkół myślenia”, a w szczególności „wielka proletariacka rewolucja kulturalna” w latach 60., kiedy ponownie w Chinach ujawniły się głębokie sprzeczności klasowe i hasło walki klasowej wykorzystywane było przez frakcję lewacką do walki wewnętrznej o władzę. Wtedy poddano prześladowaniom licznych jeszcze zwolenników konfucjanizmu, na masową skalę niszczono prace i zabytki konfucjańskie. Bez wątpienia wielką zasługą Mao było radykalne ograniczenia roli konfucjanizmu i jego miejsca w społeczeństwie chińskim. Nie oznaczało to, że całkowicie wyeliminowano zwolenników i wpływy konfucjanizmu na życie publiczne, o czym świadczyły późniejsze krytyczne wypowiedzi Deng Xiaopinga, a w szczególności pewien powrót konfucjanizmu nie tylko do oficjalnego życia publicznego Chin, także do Komunistycznej Partii Chin 5 .

Inaczej ta kwestia przedstawiała się po 1976 r. po śmierci Mao, a w szczególności od 1978 r., kiedy KPCh ogłosiła nowy program budowy socjalizmu, nazwany później „socjalistyczną gospodarką rynkową". Chiny szeroko otwarły się na świat. Napłynął wielki kapitał zagraniczny, który ciągnął olbrzymie zyski z pracy taniej siły roboczej i korzystał z wielkich zasobów naturalnych i rynkowych Chin. Władze zezwoliły na reaktywację i rozwój własnej narodowej burżuazji, która z czasem wyrosła na znaczący sektor gospodarczy, mający coraz większy udział w tworzeniu dochodu narodowego (nawet do 2/3), utrzymując jednak własność państwową w strategicznych gałęziach

5 M. Rakowski, Przemiany i szanse socjalizmu (w konfrontacji z kapitalizmem od czasów Marksa po bliska przyszłość), Warszawa 2004, s. 88 i n. 
gospodarczych, w tym także własność ziemi. Chiny otwarły się szeroko na świat zewnętrzny, co m.in. znalazło wyraz w wymianie handlowej, idących w setkach tysięcy rocznie wyjazdach młodzieży uczącej się na zagranicznych uniwersytetach i innych szkołach wyższych, głównie amerykańskich i rosnącej turystyce zagranicznej Chińczyków, która przekroczyła kilka lat temu $100 \mathrm{mln}$ turystów rocznie ${ }^{6}$.

Przejście na tory socjalistycznej gospodarki rynkowej przyczyniło się do ożywienia chińskiej polityki zagranicznej. Wiodące ośrodki burżuazyjne na świecie, w szczególności w USA, postrzegały te zmiany jako krok do stopniowego demontażu socjalizmu w Chinach, rozumiejąc gospodarkę rynkową jako związaną wyłącznie z kapitalizmem i wyrażając nadzieję na dalsze zmiany ustrojowe, podobnie jak to miało miejsce w Związku Radzieckim i europejskich krajach demokracji ludowej w końcu lat 80. i na początku lat 90 . XX w. Były to jednak płonne marzenia, kierownictwo KPCh i ChRL nie zamierzało zejść ze strategicznego kierunku i celu, jakim było podążanie i budowa socjalizmu a w dalszej perspektywie komunizmu. Zmieniły się jednak uwarunkowania zewnętrzne i wewnętrzne, a więc wymagały one zmiany drogi i metod osiągania celów strategicznych. Kierownictwo KPCh pod kierunkiem Deng Xiaopinga uczyniło ten program bardziej realistyczny do warunków zgodnie z zasadą, że trzeba budować prawdę w oparciu o fakty, dostosowując go do realiów historycznych i ekonomicznych Chin. Jednocześnie odwoływano się do konfucjańskiej paremii, że „kto zna cel, ten znajdzie do niego drogę"7.

6 Deng Xiaoping, Wyzwalać myślenie „Poszukiwać prawdy w faktach, Jednoczyć się w patrzeniu w przyszłość, [w:] idem, Chińska droga do socjalizmu. Wybór prac z lat 1956-1987, Warszawa 1988, s. 81 i n.

7 Szczególnie trudnym i delikatnym problemem reform są przemiany w rolnictwie. Por. wnikliwe studium na ten temat Jiang Changyun, China in Transition: Agriculture, Rural Areas and Farmers, Anhui 2014, s. 7 i n. 
Deng Xiaoping odszedł od wielu dogmatycznych, a nawet utopijnych stwierdzeń i zasad swego wielkiego poprzednika, opierającego się w znacznym stopni na doświadczeniach i ustaleniach teoretycznych WKP(b) i Związku Radzieckiego o szybkiej możliwości zbudowania socjalizmu i komunizmu w Chinach, kraju historycznie zacofanym, w którym podstawą bytu większości ludności było biedne, rozdrobnione i ekstremalnie zacofane pod względem postępu technicznego rolnictwo. Co prawda uspółdzielczenie wsi w latach 50. przyniosło pewien wzrost wydajności pracy, ale późniejsze zmiany spółdzielni w komuny wiejskie, będące formą ich centralizacji i administracyjnego komenderowania przyczyniły się do spadku tej wydajności, podobnie jak spadku zaufania do polityki rolnej KPCh. $\mathrm{Na}$ to nakładały się błędy polityki Wielkiego Skoku i rewolucji proletariackiej, które doprowadziły do chaosu gospodarczego i radykalnego spadku produkcji rolnej, co skutkowało głodem, a nawet śmiercią głodową w licznych prowincjach chińskich. Ten woluntarystyczny etap rządów Mao Zedonga pozostaje do dziś złym wspomnieniem po schyłkowych rządach Wielkiego Sternika ${ }^{8}$.

Problem jednak nie był tylko wynikiem błędów Mao. W tym czasie w KPCh toczyła się ostra walka pomiędzy różnymi frakcjami partyjnymi, w tym między frakcją lewacką kierowaną przez marszałka Lin Biao i małżonkę Mao Zedonga p. Jiang Qing, stojących na stanowisku skrajnego egalitaryzmu, zwanego też „koszarowym socjalizmem”. Głównym oponentem tej frakcji była frakcja Deng Xiaopinga i Liu Szaotsi, którzy uważali, że dla rozwiązania problemów Chin, kraju ekstremalnie biednego i zacofanego historycznie, niezbędne jest szerokie otwarcie na świat i wejście na drogę kooperacji z rozwiniętymi państwami kapitalistycznymi, nie stając się równocześnie ich

8 Deng Xiaoping, Przestrzegać czterech podstawowych zasad, [w:] idem, Chińska droga do socjalizmu..., op.cit., s. 99 i n. 
satelitą. Ażeby przyspieszyć rozwój Chin trzeba się było cofnąć nie o jeden krok, ograniczyć, a nawet zrezygnować z deklarowanych konstytucyjnie licznych praw socjalnych. Zezwolić na legalną działalność chińskiej inicjatywie prywatnej i wpuścić na teren kraju wielki kapitał zagraniczny, jego potężne korporacje, a także banki, które uruchomiły wielką produkcję, wykorzystując tanią siłę roboczą i surowce.

Jak wiadomo po czterdziestu latach polityka ta przyniosła wielkie osiągnięcia gospodarcze i społeczne. Chiny wyrosły na drugą gospodarkę świata, wyprowadzono z nędzy ponad 700 mln Chińczyków, jednocześnie kraj podzielił się wewnętrznie, społecznie i klasowo, powstały nowoczesne gałęzie przemysłu, rozwinęły się nowoczesne usługi, które tworzą ponad 90\% PKB. Jednocześnie odrodziła się wielka narodowa burżuazja, nadal nie jest rozwiązany problem modernizacji rolnictwa, na wsi zamieszkuje ponad pół mld ludzi, których dochody są średnio trzy razy niższe niż dochody ludności miejskiej. KPCh przyjmując program socjalistycznej gospodarki rynkowej nie odrzuciła zasady walki klasowej, uznała jednak, że na obecnym etapie nie jest ona główną sprzecznością. Podstawowa sprzeczność współczesnych Chin ma miejsce między rozwojem sił wytwórczych a rosnącymi potrzebami narodu chińskiego. Główny wysiłek narodu powinien iść $\mathrm{w}$ kierunku maksymalnego uwolnienia sił wytwórczych w oparciu o rosnące zasoby wewnętrzne, ale także otwarcie się na zewnątrz i szeroką kooperację z zagranicznymi podmiotami gospodarczymi, handel, instytucjami naukowo-technologicznymi i finansowymi.

Socjalizm jako ustrój społeczny nie jest w Chinach zagrożony. Kontrrewolucja trzymana jest w ryzach. Kierowniczą siłą pozostaje nadal Komunistyczna Partia Chin, stojąca na grun-

9 Z. Wiktor, Chiny na drodze socjalistycznej modernizacji, Toruń 2008, w szczególności część napisana przez prof. Mieczysława Rakowskiego, Rozwój Chin a świat, s. 259 i n. 
cie marksizmu-leninizmu i myśli Mao Zedonga, a jej głównym zadaniem jest wyrażanie i obrona interesów ludzi pracy. W związku z tym główna linia ideologiczna i polityka partii przyjęła postać tzw. czterech zasad: 1. trzymania się socjalistycznej drogi; 2. przestrzegania demokratycznej dyktatury ludu (proletariatu); 3. przestrzegania kierowniczej roli partii komunistycznej i 4. przestrzegania marksizmu-leninizmu i myśli Mao Zedonga. Jednocześnie złagodzono dotychczasową politykę w stosunku do konfucjanizmu, który w Chinach był i jest nie tylko rozbudowanym nurtem filozoficznym, oddziaływającym na światopogląd licznych mas ludowych, świata urzędniczego, ale częściowo będącym także jedną z głównych religii w Chinach, której wyznawcy jeszcze w 1956 r. stanowili ok. $300 \mathrm{mln}$ wiernych i była to jedna z trzech głównych religii obok taoizmu i buddyzmu. Zaprzestano dawnych praktyk administracyjno-prawnego prześladowania konfucjanizmu, z więzień i obozów reedukacyjnych zwolniono aktywnych konfucjanistów, a więc głoszących publicznie poglądy konfucjańskie, zwrócono skonfiskowano księgi konfucjańskie, jednym słowem konfucjanizm uznano jako światopogląd filozoficzny prywatny i osobisty, niezagrażający ustrojowi. W związku z tym pojawia się potrzeba przedstawienia zarysu filozofii konfucjańskiej i jej rozwoju na tle dawnych epok ${ }^{10}$.

\section{Zarys rozwoju konfucjanizmu w Chinach}

Jak wspomniano cywilizacja chińska liczy ok. 5 tys. lat, a pierwsze chińskie państwa w szczególności dynastii Xia sięgają końca III tysiąclecia p.n.e., ale wszechstronny rozwój kultury, w tym

10 Niektóre aspekty tego zagadnienia przedstawiają Tadeusz Stępień i Maurycy Zajęcki, Komunistyczna, czy Konfucjańska Partia Chin? Krytyka zbyt tatwych wyjaśnień, [w:] Globalna potęga Chin. Czynniki i perspektywy, red. Joanna Marszałek-Kawa, Toruń 2014, s. 59 i n. 
także filozofii nastąpił dopiero w okresie dynastii wschodnich Czou (Eastern Zhou), nazywanej także Okresem Wiosen i Jesieni i Walczących Królestw w latach 770-221 p.n.e. Było to następstwem szybkiego rozwoju sił wytwórczych i pełnego rozkwitu chińskiej cywilizacji, promieniującej też na państwa sąsiednie. Jednocześnie okres ten znamionowany był upadkiem władzy centralnej i rozpadem Chin na liczne państwa dzielnicowe, co m.in. sprzyjało powstawaniu różnorodności myśli społecznej, w tym kształtowaniu się licznych idei i poglądów filozoficznych, co później przybrało określenie „Sto Szkół”. Ferment i rozkład polityczny były korzystne dla powstawania warunków dla ideowego pluralizmu, jednocześnie rozbicie dzielnicowe powodowało brak stabilizacji, wzajemne walki, upadek moralności, porządku, pogłębiał się chaos, sprzyjający rządom bezprawia i zagrożeniom zewnętrznym. Zachwiane zostały dotychczasowe wartości, wyrastały warunki i kryteria nowych zasad, interesów i wartości. Z czasem rodziła się legenda o „złotych” dawnych czasach, w których panowały porządek, ład, bezpieczeństwo państwa, wspólnot wiejskich, rodzin i jednolitego państwa ${ }^{11}$.

Na tym gruncie historyczno-rozwojowym powstawały nowe kierunki myśli społeczno-politycznej, określenia istoty nowych stosunków między panującym, arystokracją i ludem, budowano nowe konstrukcje wyznaczające relacje charakterystyczne dla nowego układu sił społecznych, które opisywane były przez nowych myślicieli, będących także nierzadko politykami, którzy stanowili później prototyp uczonego - dygnitarza chińskiego. Jedną z takich postaci był Konfucjusz (Kung-cy, Kung-fu-cy), żyjący w latach 551-479 p.n.e., głównie w obecnej prowincji

11 Więcej na ten temat zob. M. Granet, Cywilizacja chińska, Warszawa 1973, s. 40 i n. Przydatnym źródłem do studiowania filozofii starożytnych chińskich filozofów, w szczególności Konfucjusza jest chińska praca przetłumaczona na angielski pt. An Introduction To Chinese Classics: Confucianism, Taoism And Buddhism, Beijing 2014, s. 30 i n. 
Shandong. Jego wielką zasługą było, że przeniósł on wiedzę o dawnej cywilizacji z okresu dynastii Czou (Zhou) do nowej epoki jako tzw „Złoty Wiek”, którą opracował i komentował w twórczy sposób. Poszukiwał wzoru społeczeństwa doskonałego, w związku z tym idealizował dawnych bohaterów, wartości i zasady wyznawane przez nich, tak w kwestiach materialnych, jak i duchowych. Konfucjusz hołdował idealistycznej koncepcji świata. Uważał on, że Przyroda i Niebo poruszają się zgodnie z określonym trybem lub drogą („tao”), odpowiednio do tego człowiek także znajduje odpowiednie miejsce we właściwym porządku, przestrzegając wszystkich związanych i uświęconych rytuałów (obrzędów) i zwyczajów („li”). Podstawową komórką społeczną jest patriarchalna rodzina, w związku z tym relacje w niej i role pełnione przez jej członków były zhierarchizowane i wyznaczały standardy funkcjonowania innych struktur społecznych, w tym państwa.

Konfucjusz dążył do stworzenia filozofii społecznej, która miała łączyć zasady etyczne, społeczne i polityczne, a także formułował zasady i sposoby sprawowania władzy państwowej, która miała przywrócić stabilną i silną władzę państwową, będącą podstawą osiągania nie tylko porządku i harmonii społecznej, ale także szczęścia człowieka. Budował on system uniwersalny, który miał obowiązywać po wsze czasy, mający jednak zakorzenienie w dawnych dziejach. Wyznaczały je pięć zasad, wartości i zależności społecznych („wu lun”): 1. syna od ojca; 2. żony od męża; 3. młodszego brata od starszego; 4. podwładnego od panującego; 5 . przyjaciela od przyjaciela. Dążył także do stworzenia wyraźnie sprecyzowanej patriarchalno-feudalnej hierarchii społecznej, w której każdy zajmowałby z góry ustalone miejsce (teoria właściwych nazw), wyznaczająca mu odpowiednie zachowanie. Podstawą tego układu była zasada żen („ren”), czyli humanitarność, „i” - sprawiedliwość oraz „li”, czyli rytuał, obrzęd, etykieta. Miało to prowadzić do 
powstania „społeczeństwa współpracującego”, którego wzorem i podstawową komórką miała być rodzina patriarchalna (zasada harmonii społecznej). Rodzina zatem była najważniejszą strukturą społeczną, a państwo było przedłużeniem rodziny patriarchalnej. W strukturze tej władca patriarchalny był ojcem swego ludu. Władca powinien być sprawiedliwy („czy”), prawy („i”), wierny („czung”), wyrozumiały i tolerancyjny („szu”). Powinna go cechować także miłość altruistyczna, humanitaryzm, ludzkość (ren), powinien respektować zasadę: „Czego nie chcesz, aby Tobie czyniono, nie czyń innym”. Powinien być człowiekiem światłym („wen”) i zachowywać wszystkie rytuały („li”) ${ }^{12}$.

Konfucjanizm wyrażał ideologię tych warstw arystokracji, które dążyły do zachowania systemu patriarchalno-rodowego i przeżytków wspólnoty w gospodarce rolnej. Stał on na gruncie naturalnych (dla niego) różnic klasowych, gloryfikował nierówności klasowe i uważał je za niezmienne, w związku z tym krytycznie oceniał bogacenie się i wywyższanie ludzi z niższych klas. Zgodnie z nauką Konfucjusza każdy człowiek powinien zajmować określone miejsce w społeczeństwie. Podkreślała to jego paremia: cesarz powinien być cesarzem, poddany - poddanym, ojciec - ojcem, syn - synem. Konfucjaniści byli zdecydowanymi obrońcami niezmiennego ustroju patriarchalnego i przywiązywali wielkie znaczenie dla kultu przodków, co stało się później podstawą religii konfucjańskiej ${ }^{13}$. W centrum doktryny Konfucjusza szczególne miejsce mieli pełnić „ludzie szlachetni” („cun cy”), czyli intelektualiści mający pomagać władcom i kierować „gminem” (ludem) w pracy nad

12 W. Rodziński, Historia Chin, Wrocław, Warszawa-Kraków- Gdańsk 1974, s. 58-61, zob. też: Konfucjanizm, [w:] Wielka encyklopedia powszechna, t. 5, red. B. Suchodolski, Warszawa 1963, s. 797.

13 Historia powszechna, t. 2, Warszawa 1964, s. 501, zob. też: A. Kość, Konfucjanizm, [w:] Powszechna encyklopedia filozofii, red. A. Maryniarczyk, Lublin 2004, s. 785-789. 
odbudową starego „złotego ustroju” z okresu wcześniejszych dynastii Szang (Shang) i pierwszych Czou (Zshou). Podstawową kwestią było ustanowienie prawidłowych relacji między człowiekiem, współżyciem ludzi i sposobami rządzenia, tak by prowadziły one do doskonalenia osobowości człowieka. Podstawą tego założenia była zasada, że wszystko, co się dzieje musi być zgodne „z ładem nieba” („tao”). Znajomość tego "ładu” i opartych na nim prawideł postępowania w stosunkach międzyludzkich stanowiła centralny punkt doktryny, która stała się typową „religią bez boga”, nastawioną na regulację współżycia ludzi. Rozwój i dalsze przekształcenie się konfucjanizmu w religię trwał wiele stuleci. Początkowo konfucjanizm nie znajdował uznania wśród panujących, znalazł jednak uznanie wśród intelektualistów i urzędników (mandarynów) i wyrażał ich aspiracje społeczno-polityczne i kulturalne. Stawał się doktryną tej nowej rosnącej na znaczeniu warstwy urzędniczej, która w chińskim feudalizmie znalazła dla siebie ważne miejsce społeczne. Konfucjusz jako arystokrata gardził ludem, który traktował przedmiotowo. Nad ludem władca ma panować, prowadzić go, lud nie może być traktowany za równorzędną część społeczeństwa, a tym bardziej nie można mu przyznawać jakiejkolwiek roli politycznej. Naukę Konfucjusza w swym pierwotnym założeniu da się określić jako swoisty kodeks moralno-etyczny i polityczny dla panującego, wyznaczał nawet nowe standardy kierowania państwem, można go jako takiego porównać do N. Macchiavellego z Florencji, żyjącego w zupełnie inne epoce, który w dziele Książe przedstawił swoiste rady dla władcy, jak dobrze i skutecznie rządzić państwem ${ }^{14}$.

Konfucjanizm był rozwijany przez uczniów założyciela, w tym Cy-sy, Jang-Siung, a później Meng-cy i Sun-cy w IV-

14 K. Grzybowski, Nicolo Machiavelli, Książę, Warszawa 1970, zob. też: M. Baranowska, Cel uświęca środki, czyli Nicolo Machiavellego rozważania o wtadzy, Toruń 2018. 
-III w. p.n.e. W tym czasie Chiny popadły w jeszcze większy chaos polityczny, co rzutowało na kryzys gospodarczy i upadek dotychczasowych osiągnięć chińskiej cywilizacji. Nauki Mengcy (Mencjusza) to wielkie wołanie o silne i sprawiedliwe rządy, stabilizację i bezpieczeństwo wewnętrzne oraz zewnętrzne kraju. Mencjusz był także zwolennikiem idealizmu, co znalazło wyraz w koncepcji Nieba jako wiodącej idei w sprawach ludzkich, ale jednocześnie mocniej formułował rolę ludu jako podmiotu, co znalazło wyraz, że głos ludu jest głosem Nieba (co przypomina zasadę starożytnego Rzymu: „vox populi - vox dei”). Znalazło to wyraz w idei „mandatu Nieba”, co oznaczało, że władca sprawuje władzę z „mandatu Nieba”. Jeśli władca źle rządzi, popełnił błędy lub zbrodnie, może być usunięty, gdyż stracił „mandat Nieba”. Ta kategoria panowania za sprawą „mandatu Nieba” i władcy jako wysłannika (mandatariusza Nieba) dotrwała aż do XX w. i nawet termin „rewolucja” oddany jest przez słowa „ko ming” (zmiana mandatu), przy czym owa zmiana rządu mogła być dokonana przez jego ministrów bądź rodzinę, ale nie przez lud. Stosunek Mencjusza do ludu był nie mniej paternalistyczny niż Konfucjusza, co było wyrazem jego klasowo-feudalnego myślenia. Mencjusz był filozoficznym przedstawicielem arystokracji. Według niego społeczeństwo składało się zasadniczo z dwóch klas: pracujących fizycznie (lud) i umysłowo (szlachetnie urodzeni). Zadaniem pierwszej grupy było utrzymanie drugiej klasy i rządzenie ludem. Jednocześnie Mencjusz zwracał uwagę, że dobry władca powinien zabezpieczać dobrobyt ludu, gdyż jest to warunkiem dobrego wykonywania jego obowiązków i na tym polegała istota dobrych rządów. Nowym elementem nauki Mencjusza była idea o wrodzonej dobroci natury ludzkiej. Podkreślał on ważną rolę edukacji, szczególnie pochwalał w stosunkach społecznych synowskie oddanie, co przyczyniało się do umocnienia nie tylko rodziny, także państwa. 
W III w. p.n.e. konfucjanizm rozwinął się także w kierunku materialistycznym, zawierał także pewne elementy taoizmu i legizmu. Jego wybitnym przedstawicielem był Sun Cz’ing, który dowodził, że Niebo nie odgrywa żadnej roli w życiu człowieka. Można go uznać za przedstawiciela chińskich agnostyków bądź nawet ateistów i pod tym względem mógł wywrzeć pewien wpływ na ideologię rodzącej się w latach 20. Komunistycznej Partii Chin. W odróżnieniu jednak od komunistów, którzy na ogół są optymistami Sun był pesymistą, twierdząc, że natura ludzka jest od początku życia zła. Można się jej przeciwstawić przez edukację. Uczniowie Suna znaleźli porozumienie z legistami, propagującymi m.in. rządy prawa i konieczność rządów silnej ręki, a nawet niezbędność surowych kar ${ }^{15}$.

W V-IV stuleciu p.n.e. powstawały także inne prądy filozoficzne i religijne. Jednym z nich był taoizm. Za twórcę tej filozofii uznaje się Lao Tzu. Najwcześniejszym dziełem tej nauki było Tao Te Czing (Droga i jej potęga). Zdaniem W. Rodzińskiego można ją było uznać jako filozofię sprzeciwu wobec niesprawiedliwości, rozkładu i korupcji ówczesnego społeczeństwa. Celem życia człowieka powinno być osiągnięcie zgodności z „Tao”, przy czym nie jest to „droga”, jak w nauce Konfucjusza, lecz bardziej „pierwsza zasada wszechświata”, swoisty „ład przyrody”. Taoizm był filozofią krytyki wobec niesprawiedliwości, rozkładu i korupcji, należy żyć zgodnie i w harmonii, wobec zła stawiać bierny opór. Pożądany jest powrót do stanu pierwotnego każdego rządu, a więc była to negacja ówczesnych form panowania. Podstawową kategorią była zasada „wu wei”, czyli bezczynność, bierność. Ideałem Lao

15 W. Rodziński, Historia Chin..., op.cit., s. 65. Nowatorską interpretację historii Chin, w szczególności przywództwa i władzy państwowej w Chinach (na tle rozwoju konfucjanizmu) przedstawia J. Sielski, Polityczne wzory przywództwa i wtadzy w Chinach, [w:] Wektory zmian w polityce Chińskiej Republiki Ludowej w okresie rządów Xi Jinpinga, red. J. Marszałek-Kawa, M. Bidziński, Toruń 2018, s. 202 i n. 
Tzu był nie mityczny „Złoty Wiek”, lecz prymitywna wspólnota wiejska, która istniała jeszcze wcześniej i przetrwała mimo upadku różnych państw i dynastii. W późniejszych wiekach taoizm rozwinął się w różne szkoły, przyjął także pewne elementy mistycyzmu i ze względu na poszukiwanie jego źródeł we wspólnotach wiejskich stał się religią znacznej części mas plebejskich, a jego wartości znalazły się na sztandarach ludowych powstań. Taoizm, negując porządki państwa feudalnego, stawał się prądem społeczno-politycznym nieprzyjaznym porządkowi feudalnemu, przez który był zwalczany. Komuniści częściowo nawiązywali do niektórych haseł taoizmu w swej walce z Kuomintangiem i krytyki pozostałości feudalizmu, które dawały o sobie znać także po rewolucji 1949 r. ${ }^{16}$

Znaczący wpływ na życie ideowo-społeczne starożytnych Chin odegrała także filozofia Mo Ti, żyjącego na przełomie $\mathrm{V}$ i IV w. p.n.e., zwana mohizmem i kontynuowana przez jego uczniów. Mohizm i jego różne szkoły postrzegany jest w literaturze jako swoisty ideowy konkurent konfucjanizmu. Niektórzy znawcy mohizmu traktują go jako filozofię materialistyczną, stawiającą sobie jako cel społeczny osiągnięcie społeczeństwa idealnego. Mo Ti głosił, że droga do tego celu wiedzie przez wzbogacenie kraju, wzrost liczby ludności, zachowanie ładu oraz zabezpieczenie dobrobytu ludu. Sprzeciwiał się ulubionym przez konfucjanistów rozrzutnym ceremoniałom, krytykując je jako marnotrawne. Potępiał wojny agresywne jako niebraterskie, mordercze i marnotrawne, czyli niesprawiedliwe. Był jednocześnie zwolennikiem wojny obronnej. Założenia te są do dziś aktualne w społeczeństwach nastawionych pokojowo, także w Chińskiej Republice Ludowej, której doktryna wojenna oparta jest na taktyce defensywnej.

16 W. Rodziński, Historia Chin..., op.cit., s. 69-70. Więcej na temat taoizmu i jego stosunku do konucjanizmu zob. Li Weida, Yin Xiangfeng (red.), Chińskie ABC, Brzezia Łąka 2016, s. 205 i n. 
Główną doktryną filozofii Mo Ti była zasada „powszechnej miłości”, którą widział jako godną stosowania przez wszystkie państwa i narody, co mogłoby stanowić podstawę eliminacji źródeł konfliktów społecznych i wojen. W doktrynie tej jest zapowiedź uznanej obecnie przez postępowe państwa i narody praktyki pokojowego współistnienia, której także hołduje Chińska Republika Ludowa. Słabością tej nauki jest usytuowanie czynnika sprawczego tak pożądanego porządku społecznego w koncepcji „powszechnej miłości”, a więc w czynniku emocjonalnym i moralnym. Autor nie wskazywał na gwarancje materialne, a przede wszystkim siły społecznej, która mogłaby wprowadzić realizację tak szczytnej idei. Jednocześnie tak humanistyczna i równościowa koncepcja filozoficzna nie mogła się podobać ówczesnym władcom, gdyż naruszała podstawy panujących wtedy stosunków feudalnych Chin i zagrażała ich panowaniu $^{17}$.

Innym kierunkiem filozoficznym ze znacznymi elementami doktryny politycznej był legizm, który wykształcił się w IV w. p.n.e. Za jego twórcę uważa się Han Fei, który był uczniem Sun Cz’inga - jednego z kontynuatorów konfucjanizmu. Zawarł on podstawowe idee legizmu w pracy Han Fei Tzu (Księga Mistrza Han Fei). Nazwa kierunku nawiązywała do ważnej roli prawa w życiu społecznym. Legiści czerpali natchnienie z idei konfucjanizmu, taoizmu i mohizmu, ale odrzucali ideały antyczności jako mitycznego ideału, podkreślali natomiast znaczenie prawa i potęgi panującego, jak również konieczność ustanowienia właściwego systemu kar i nagród. Mieli bardzo pragmatyczny i utylitarny stosunek do nauki i wiedzy. Idealizowali przemoc i siłowe instrumenty wymuszania porządku społecznego. Mieli krytyczny stosunek do nauki, historii, kultury, filozofii, sztuki i moralności. Były one ich zdaniem całko-

17 W. Rodzińskie, Historia Chin..., op.cit., s. 72. 
wicie zbędne, szkodliwe, a nawet wywrotowe. W ich koncepcji idealnie zorganizowanego społeczeństwa naczelne i kierownicze stanowisko zajmował panujący, władca, dysponujący sprawnym aparatem, zdyscyplinowanym i wymagającym posłuszeństwa od ludu, jak i od podległych urzędników. Lud pozbawiony był możliwości dostępu do edukacji i wiedzy, nie miał zajmować się myśleniem, ale miał okazywać ślepe posłuszeństwo królowi, cesarzowi. Zdaniem legistów człowiek z natury jest zły i samolubny, gdyby nie państwo i władza wszyscy by walczyli ze sobą, prowadząc do chaosu. W związku z tym powstaje potrzeba istnienia silnej władzy państwowej, która może utrzymać takie samolubne społeczeństwo w ryzach. Tylko w silnie zorganizowanym, scentralizowanym i zmilitaryzowanym społeczeństwie można zapewnić ład i porządek oraz zapewnić rozwój społeczeństwa. Legiści stworzyli teoretyczne podstawy dla późniejszego bezwzględnego i drapieżnego absolutyzmu cesarstwa Cz’in (Qin). Społeczeństwo było przedstawiane jako piramida, na czele której stał despotyczny władca, mający do dyspozycji biurokrację wojskową i masy ludowe.

Koncepcja legistów odpowiadała nowym rodzącym się stosunkom społecznym, w których zanikała dawna arystokracja rodowa i rodziła się nowa arystokracja - biurokracja wojskowa wielkich nowych obszarników, będących podporą władzy cesarza $^{18}$. Koncepcja legistów zrobiła wielką karierę jako podstawa teoretyczna późniejszej scentralizowanej władzy dynastii Cz'in (Qin), trwającej krótko w latach 221-207 r. p.n.e., której władca po raz pierwszy w historii Chin podbił i zjednoczył wszystkie dotychczasowe podzielone księstwa i królestwa oraz stworzył cesarstwo, które odpowiednio zreformował i zorganizował w pełni scentralizowany, jak również zmilitaryzowany organizm polityczno-administracyjny. Jednocześnie przepro-

18 Ibidem, s. 71. 
wadził liczne reformy gospodarcze, finansowe, komunikacyjne, obronne, które uczyniły z Chin jednolity kraj, spajany też osiągnięciami kultury i cywilizacji chińskiej. Od tego czasu Chiny stały się wielkim mocarstwem, które potrafiło wchodzić w stosunki gospodarcze i handlowe nawet $\mathrm{z}$ najbardziej odległymi państwami ówczesnego świata, m.in. z Cesarstwem Rzymskim. Kult silnej władzy, scentralizowanych rządów przyświecał wielu innym dynastiom chińskim, sięgającym w późniejszej historii do wzorów Qin, nie zawsze się to udawało i Chiny wielokrotnie padały ofiarą własnych słabości bądź siły sąsiadów, musiały także znosić obce panowanie, np. w epoce mongolskiej (Yuan) czy panowania mandżurskiego (Qing), ale dzięki swej wielkiej cywilizacji po pewnym czasie udawało im się obalić obce panowanie i odbudować własną potęgę.

Wielką rolę ideowo-polityczną w tych historycznych procesach odegrał konfucjanizm, a także zbliżone kierunki filozoficzne i religijne jako podstawa kulturowa chińskiej cywilizacji. Były one ważnym lepiszczem filozoficznym i religijnym narodu chińskiego, niezależnie od różnic ontologicznych i epistemologicznych a także ich utylitarności w realizacji celów społecznych, głównie politycznych. W kolejnych wiekach i epokach uczniowie oraz kontynuatorzy tych nauk niezależnie od różnic podkreślali znaczenie i rolę dawnej tradycji. Ludzie powinni postępować zgodnie z zasadami określającymi ich miejsce w feudalnej hierarchii społecznej i głosiły kult przeszłości. Jak już wspomniano, w okresie dynastii Cz’in (Qin), 221-207 r. p.n.e. dotychczasowy król zjednoczył państwo, podbił inne tereny i uzależnił liczne inne państewka od Cz’in, co umocniło jego autorytet i władzę tak wewnątrz, jak i na zewnątrz kraju. Jako pierwszy władca Chin przybrał tytuł cesarza i wprowadził liczne reformy w zarządzaniu, obronności i komunikacji w kraju. Były to cechy idealnego wręcz państwa i postulowanego przez konfucjanizm porządku społecznego, 
ale cesarz nie znalazł zrozumienia dla tej doktryny, a nawet nakazał spalenie wszystkich jego ksiąg. Panowanie pierwszego wielkiego cesarza nie trwało długo, po jego śmierci, za dynastii Han nastąpił renesans konfucjanizmu. W renesansie doktryny pomogło liczne grono uczniów, którzy z pamięci odnowili księgi Konfucjusza, opatrując je także własnymi oryginalnymi komentarzami. Konfucjanizm stał się oficjalną doktryną filozoficzną, z czasem religią państwową i teoretyczną podstawą biurokratyczno-feudalnej monarchii chińskiej. W okresie dynastii Han, która dzieliła się na Zachodnią (206 r. p.n.e.-24 r. n.e. i Wschodnią (25-220 r. n.e.), nastąpiła modyfikacja jego zasad odpowiednio do nowej epoki.

W okresie Wczesnej Dynastii Han (Zachodniej) Chiny przeżywały okres dużego rozwoju, co było z jednej strony kontynuacją poprzedniego etapu z dynastii Qin, kiedy państwo zostało zjednoczone i scentralizowane oraz osiągnęło niebywały rozwój terytorialny i ludnościowy. Nastąpił szybki rozwój gospodarczy, wdrożono nowe techniki produkcyjne, rozwijał się handel, także zagraniczny, odchodzono od pozostałości niewolnictwa na rzecz gospodarki feudalnej, czemu towarzyszyły zmiany w rozwoju kultury i nauki. Silna i scentralizowana władza potrzebowała państwowej ideologii, wspierającej oraz uzasadniającej władzę cesarza, do czego znakomicie nadawał się konfucjanizm.

Liu Pang, który był jednym z założycieli nowej dynastii, początkowo odnosił się wrogo do konfucjanizmu. Przyczyna była prosta, zdobył on władzę w drodze powstania ludowego, a to nie mogło się podobać konfucjonistom, ale zmienił swój stosunek, gdy udzielili mu swego poparcia $\mathrm{w}$ walce $\mathrm{z}$ innymi pretendentami do tronu cesarskiego. Przydatne okazały się dla umocnienia władzy niektóre ceremonie konfucjańskie, ale Liu Pang nie odwołał całkowicie edyktu cesarza Ts'in o potępieniu Ksiąg konfucjańskich. Uczynił to dopiero jego następca Wu-ti 
(140-107 r. p.n.e.), uznając konfucjanizm za urzędową panującą ideologię. Nauka Konfucjusza stała się podstawą egzaminów obowiązujących urzędników państwowych, dotyczyło to m.in. traktatu o sztuce rządzenia państwem, napisanego stosownie do nowej epoki przez Tung Czung-szu. Wu-ti oparł się na nowej arystokracji, uzależnił ją od siebie nowymi nadaniami i przywilejami, ponownie scentralizował państwo, wprowadził sprawną administrację, szczególnie finansową i wojskową, liczne monopole państwowe, zapewniające stały dopływ pieniędzy do kasy państwowej. Z czasem konfucjanizm stał się jedyną ideologią panującą $\mathrm{w}$ cesarstwie i nastąpiło potępienie innych nauk $^{19}$.

Po upadku dynastii Han wystąpił też upadek scentralizowanej władzy cesarskiej, co osłabiło konfucjanizm jako ideologię i religię państwową. Jednocześnie nastąpił wzrost wpływów buddyzmu, importowanego z Indii i Tybetu. Ponowna restytucja konfucjanizmu nastąpiła w okresie dynastii Tang (618-907), dążącej do odtworzenia scentralizowanej i mocarstwowej potęgi cesarskiej Chin. Proces ten rozpoczął się w okresie poprzedzających dynastię, około 550 r. nastąpiło restytuowanie konfucjanizmu jako religii państwowej, przy czym nie chodziło już władcom o rekonstrukcję wcześniejszych wczesnofeudalnych form ustrojowych, ale budowanie scentralizowanego biurokratycznego aparatu władzy, w którym centralne miejsce zajmować miała warstwa wyszkolonych na zasadach konfucjanizmu urzędników.

W dalszych latach konfucjanizm zaczął wywierać duży wpływ na kształtowanie stosunków społecznych przez system egzaminów państwowych, uprawniających do zajmowania stanowisk urzędniczych, co konserwowało i wychowywało społeczeństwo chińskie w duchu tradycjonalizmu i formalizmu.

19 Historia powszechna..., op.cit., s. 539-541. 
Jednocześnie konfucjanizm coraz bardziej przekształcał się w filozofię teistyczną i ewoluował w kierunku teleologicznym. Głównym teoretykiem tego kierunku był Tung-Czung-sing, opierający się na zasadzie „in-jang” i teorii pięciu elementów („wu-sing”), który stworzył metafizyczną podstawę konfucjanizmu i powiązał go z teistycznym teleologizmem. Konfucjanizm rozwinął się w XI-XII w. w walce z teistyczno-mistycznymi dążeniami buddyzmu, kiedy pojawiły się próby stworzenia nowej jego podbudowy teoretycznej. Do najważniejszych reformatorów konfucjanizmu w tym okresie należał Czu Si, twórca neokonfucjanizmu, który dominował w chińskiej myśli i kulturze aż do XX w., spełniając w niej funkcje integrujące, stał na straży klasowej przewagi elementów feudalnych i wywierał przemożny wpływ na wszystkie dziedziny życia społecznego Chin, na kształtowanie mentalności chińskiego systemu rządów, wychowania i kultury.

Konfucjanizm jako doktryna polityczna związana z cesarstwem został odrzucony dopiero na początku XX w. przez siły dążące do obalenia starego systemu, ale pewne jej elementy pozostały w obyczajowości i zachowaniach (rytuałach) warstwy urzędniczej. Natomiast nadal silna była pozycja konfucjanizmu jako religii, który nie tylko przetrwał okres 1 . republiki, ale nawet po zwycięstwie rewolucji ludowej w 1949 r. był nadal jednym z trzech głównych wyznań w Chinach. Oficjalnie według danych statystycznych z $1956 \mathrm{r}$. konfucjanizm wyznawany był przez 300 mln wiernych ${ }^{20}$.

20 B. Suchodolski (red.), Wielka encyklopedia powszechna..., op.cit., s. 797. Więcej na ten temat powiązań konfucjanizmu z innymi kierunkami filozoficznymi zob. W. Rodziński, Historia Chin..., op.cit., s. 62. 


\section{Walka między konfucjanizmem a marksizmem w XX w. i wkład Mao Zedonga w rozwój marksizmu w Chinach}

Początki tego problem należy widzieć w wielkim fermencie ideowo-politcznym, w którym nalazły się Chiny poczynając od poł. XIX w., kiedy wpadły w orbitę polityki mocarstw zachodnich i Japonii, które dążyły do podporządkowania sobie Chin, otwarcia ich na penetrację kapitału przemysłowego i finansowego, narzucenia im zależności kolonialnej lub półkolonialnej, a nawet ich podboju i rozczłonkowania. W związku z tym w Chinach budziły się siły narodowe, wybuchały powstania ludowe tajpingów i bokserów, powstawały zalążki kapitalizmu, chińska burżuazja narodowa i początki klasy robotniczej. $\mathrm{Na}$ tym tle w środowiskach patriotycznych Chin rosło zainteresowanie systemem gospodarczym i politycznym państw Zachodu, z uwagą śledzono też wyniki reform Meiji w sąsiedniej Japonii, której groziły podobne niebezpieczeństwa co Chinom, ale Japonia dzięki tym reformom zwycięsko je odparła i budowała silną pozycję gospodarczą i polityczną. Pogłębiała się krytyka zmurszałego systemu rządów mandżurskiej dynastii Qing. Wśród licznych krytyków systemu nowością były tezy marksistowskie, które dotarły do Chin pod koniec XIX w., a na większą skalę na początku XX w., co znalazło wyraz w książce o komunizmie (1899 r.), pierwszych tłumaczeniach prac Marksa i Engelsa, w szczególności części Manifestu komunistycznego i Rozwój socjalizmu od utopii do nauki (1912 r.). Zainteresowanie marksizmem wzrosło po obaleniu cesarstwa w 1911 r. W 1915 r. Chen Duxiu publikował w czasopiśmie szanghajskim liczne artykuły na temat marksizmu. Prace te kontynuował znany ówczesny młody marksista, także współ- 
założyciel Komunistycznej Partii Chin w 1921 r. Li Dazhao, tłumacząc dalsze części Manifestu, także pracy pt. Przyczynek do krytyki ekonomii politycznej (w części) i inne. Dał on w miarę rozwiniętą informację naukową o trzech częściach naukowego socjalizmu, teorii i metodologii materializmu historycznego i ekonomii politycznej. Nowej jakości nabrał rozwój marksizmu w Chinach po zwycięstwie rewolucji październikowej w 1917 r. i założeniu w lipcu 1921 r. Komunistycznej Partii Chin ${ }^{21}$.

Wraz z obaleniem cesarstwa upadły także przesłanki wielkiej społecznej roli konfucjanizmu jako ideologii i religii zmurszałego ustroju feudalno-cesarskiego. Ale walka między siłami reakcyjnymi i promonarchicznymi a postępowo-republikańskimi trwała w dalszym ciągu i wiązała się z próbami restytucji cesarstwa, czemu także sprzyjały mocarstwa zamorskie, mając na uwadze własne interesy. Chińscy postępowcy dążyli nie tylko do obalenia cesarstwa, także do osłabienia i marginalizacji konfucjanizmu jako ideowo-religijnej podpory sił monarchicznych, m.in. atakowali reakcyjny rząd pekiński, który zamierzał wprowadzić do konstytucji punkt uznający konfucjanizm jako oficjalne wyznanie Chin. Zamierzenia te stały się celem silnej krytyki ze strony chińskich marksistów, w tym Chen Duxiu, Wu Ju, a najbardziej konsekwentnie Li Dazhao, którzy podkreślali, że konfucjanizm jest nieodłączną częścią systemu monarchicznego i kto opowiada się za nim, występuje $\mathrm{w}$ istocie o restaurację monarchii. Wu Ju wskazywał na więź konfucjanizmu z tradycyjnymi stosunkami społecznymi, z despotyzmem i ustrojem rodowym, uzasadniał, że stanowi on przeszkodę postępu i rozwoju współczesnej nauki. Najbardziej konsekwentnym krytykiem konfucjanizmu był Li Dazhao. Nazywał on Konfucjusza „zasuszonym tysiącletnim trupem”, któ-

21 Zheng Hangsheng, Li Yingsheng, Historia chińskiej socjologii, Toruń 2010, s. 125-126. 
rego teoria odzwierciedlała naukę i moralność współczesnego mu społeczeństwa. Mówił, że „Konfucjusz w XX w. to regres”. Inny marksista Caj Juan-pej dowodził, że religia, w tym także konfucjanizm, służy reakcyjnym klasom panującym, zaszczepia nietolerancję, prowadzi do waśni i wojen ${ }^{22}$.

Konfucjusz i konfucjanizm stały się w następnym okresie sztandarem Kuomintangu i gen. Czang Kajszeka w walce z komunistami. W 1934 r., dążąc do wzmocnienia antykomunistycznego frontu, sięgał do haseł tej wydawałoby się przebrzmiałej cesarskiej ideologii. Ogłosił kampanię „ruchu o nowe życie”. Jego głównymi celami miało być odrodzenie i upowszechnienie konfucjańskich ideałów, w tym „li, „i”, „cien” i „czy”, czyli „przestrzeganie rytuału”, „sprawiedliwości”, „skromności” i wstydliwości”. Kuomintangowcy argumentowali, że „źródło odrodzenia państwa tkwi nie w sile oręża, lecz w rozległości wiedzy i cnocie narodu”. Powołując się na Konfucjusza uznano, że główną cnotą jest podporządkowanie młodszych starszym, stojącym niżej - stojącym wyżej, narodu - władzom. W maju 1934 r. został oficjalnie przywrócony kult Konfucjusza ${ }^{23}$.

O tym jak mocno konfucjanizm tkwił w świadomości Chińczyków, w tym także ich postępowej części, świadczy postać Sun Yatsena - bohatera nowoczesnych Chin, który przyczynił się walnie do obalenia cesarstwa, został obrany na pierwszego prezydenta republiki, ale jednocześnie z szacunkiem odnosił się do jego tradycji, powagi i autorytetu, mówił, że sam jest konfucjanistą. Na uwagę zasługuje, że Sun Yatsen był założy-

22 Podaję za: M.I. Sładkowskij et al. (red.), Najnowsza historia Chin 1917-1976, tłum. J. Urkowski, Warszawa 1976, s. 78. Zob. też A. Kość, Prawo a etyka konfucjańska w historii myśli prawnej Chin, Lublin 1998; T. Czarnik, Starożytna filozofia chińska, Kraków 2001: Feng Youlan, Krótka historia filozofii chińskiej, Warszawa 2001.

23 M.I. Sładkowskij et al. (red.), Najnowsza historia Chin..., op.cit., s. 214 . 
cielem Kuomintangu, którego immanentną częścią w latach 20. XX w. była KPCh, a wdowa po Sun Yatsenie była współzałożycielką Chińskiej Republiki Ludowej, proklamowanej 1 października 1949 r. w Pekinie przez Mao Zedonga.

Rozwój marksizmu w Chinach przebiegał dwoma drogami. Była to droga uniwersytecka, gdzie wybitni uczeni pod wpływem studiów na Zachodzie przenosili na teren Chin główne założenia teorii i metodologii marksizmu, które wpływały na środowiska intelektualistów i studentów. Drugą drogą był rozwijający się ruch robotniczy, w szczególności komunistyczny. Przypomnijmy główne nazwiska zasłużonych dla propagowania marksizmu w tym środowisku: Hu Deheng badał podstawowe teorie socjologiczne zgodnie z założeniami materializmu historycznego i stał się współtwórcą marksistowskiej socjologii. Dużą rolę odegrali wspomniani już tacy badacze, jak Li Dazhao, Qu Qiubai i Li Da, którzy przywiązywali dużą wagę do badania problematyki struktur społecznych. Li Da np. wprowadził do chińskiego marksizmu kategorie baza i nadbudowa, wiążąc tą pierwszą ze stosunkami ekonomicznymi, drugą zaś z polityką, prawem, ideologią itd. Jednocześnie wskazywał na wzajemne powiązania między nimi i wzajemne oddziaływanie. Dużą rolę w kształceniu kadr marksistowskich odegrały studia licznych uczonych i studentów na uniwersytetach Europy Zachodniej, a przede wszystkim na uniwersytetach Rosji i Związku Radzieckiego, głównie na moskiewskim Uniwersytecie Sun Yatsena (Narodów Wschodu) i w instytucjach Międzynarodówki Komunistycznej, z których wielu z nich było czołowymi działaczami KPCh i rodzącej się Chińskiej Republiki Radzieckiej, organizowanej na terenach wyzwolonych przez partyzantkę komunistycznąa ${ }^{24}$.

24 J. Fenby, Chiny. Upadek i narodziny wielkiej potęgi, Kraków 2009, w szczególności s. 311 i n. 
Szkoła marksistowska prowadziła nie tylko badania o charakterze ogólnoteoretycznym. Jednocześnie pojawiły się oryginalne badania empiryczne, których rezultaty pozwalały poznać istotę stanu i przemian struktury klasowej, demograficznej, etnicznej ludności Chin w latach 20.-30. XX w., a także wykorzystano je dla pogłębienia badań historycznych nad tymi problemami. Walor tych badań polegał nie tylko na rezultatach poznawczych, pozwalał KPCh na naukową analizę sprzeczności społeczeństwa chińskiego, sposobów ich rozwiązywania i organizowania walki z wyzyskiem i niesprawiedliwością społeczną. Więcej uwagi poświęcono chlopstwu jako głównej sile rewolucynej Chin. Pozwalały także na zbudowanie poprawnego, opartego na przesłankach naukowych programu bieżącego i perspektywicznego tej walki prowadzonej przez $\mathrm{KPCh}^{25}$.

Mao Zedong był modelowym przykładem łączenia teorii i praktyki. Jak większość ówczesnych działaczy komunistycznych był samoukiem. Z domu wyniósł dość gruntowne wychowanie i wykształcenie konfucjańskie, tak że mógł ze znawstwem posługiwać się argumentami czerpiącymi z konfucjanizmu. Jako młodzieniec szybko opuścił dom rodzinny w Shaoshan i udał się na dalsze kształcenie i jednocześnie do pracy w stolicy prowincji Hunan Changsha. Później przeniósł się do Pekinu, gdzie m.in. pracował w bibliotece uniwersyteckiej, w której miał okazję poznać niektóre prace marksistowskie, co pozwoliło mu wejść w środowisko marksistowskich intelektualistów. Okres ten okazał się przełomem w dalszym życiu młodego Mao, od tego czasu zrozumiał, że walka o wyzwolenie spod wyzysku ludu chińskiego musi odbywać się w oparciu o marksizm. Ten kierunek myślenia utrwaliły wydarzenia w sąsiedniej Rosji, gdzie w 1917 r. wybuchły rewolucje

25 Więcej na ten temat zob. Zheng Hangsheng, Li Yingsheng, Historia chińskiej socjologii..., op.cit., w szczególności rozdz. 3: „Wprowadzenie marksistowskiej socjologii..., s. 125 i n. 
(lutowa i październikowa), które była dowodem, że można nie tylko obalić stary zmurszały ustrój carski, ale także kapitalizm i zapoczątkować przemiany rewolucyjne ku socjalizmowi. Mao czerpał inicjatywę rewolucyjną z wielkich tradycji buntów chłopskich, które niejednokrotnie w historii Chin demonstrowały wielką siłę i determinację chińskiego ludu w walce ze społeczną niesprawiedliwością, co początkowo wiązało go z koncepcją tzw. „socjalizmu agrarnego". Hunan stał się dla Mao matecznikiem ruchu rewolucyjnego wśród mas chłopskich. W 1921 r. w lipcu wziął udział w Zjeździe marksistów chińskich w Szanghaju, który przekształcił się w I Zjazd Komunistycznej Partii Chin. Po rozbiciu KPCh przez Czang Kajszeka w 1927 r. Mao podjął się dzieła odbudowy partii w oparciu o substrat chłopski, wychodząc z założenia, że w Chinach, w których zdecydowanie w strukturze społecznej dominuje klasa chłopska właśnie w oparciu o nią należy odbudować partię, od tego czasu KPCh rozwijała się pod kierownictwem Mao Zedonga, który prowadził ją poprzez liczne walki i zwycięstwa aż do śmierci w 1976 r. Jego wielką zasługą była nie tylko odbudowa partii, także zwycięskie walki partyzanckie z wojskami Kuomintangu, walki z Japończykami, Wielki Marsz w 1934/1935 r., a po 1945 r. zwycięska walka o wyzwolenie kraju i powstanie w 1949 r. Chińskiej Republiki Ludowej ${ }^{26}$.

Mao Zedong był nie tylko wybitnym przywódcą, dzięki nieustannej pracy i samokształceniu stał się także wybitnym marksistą, rewolucjonistą, mężem stanu, strategiem i myślicielem, który kierował partią, później państwem, popularyzował marksizm na potrzeby partii, a także przeprowadził liczne badania i studia nad konkretnymi strukturami społecznymi. Były to analizy struktury klasowej społeczeństwa chińskiego, analiza procesu rewolucyjnego w Chinach, sił społecznych chińskiej

26 W.J. Dziak, J. Bayer, Mao. Zwycięstwa, nadzieje, klęski, Warszawa 2007, s. 9 i n. 
rewolucji, poświęcił także dużo uwagi historii społeczeństwa chińskiego, traktując je jako społeczeństwo feudalne, trwające w Chinach ok. 2,5 tys. lat, w szczególności wiele uwagi poświęcając analizie położenia społeczno-gospodarczego chińskiego ludu, głównie chłopów, instrumentów ucisku ekonomicznego, politycznego i ideologicznego, wśród których ważną rolę odgrywał konfucjanizm. Mao Zedong w swych badaniach dużo uwagi poświęcił rozwojowi kapitalizmu i nowej klasy społecznej - robotników, których przywództwo polityczne uznawał zgodnie z zasadami marksizmu, ale wiodącą siłą chińskiej rewolucji był proletariat wiejski i biedni chłopi. Była to podstawowa lekcja marksizmu w warunkach chińskich, która wynikała z konkretnej analizy głównych sprzeczności społecznych Chin, oparta na realiach i wyciągania wniosków z dziejącej się historii, z faktów. Liczne prace Mao dotyczyły analizy stosunków zagranicznych, sprzeczności międzynarodowych, relacji Chin z mocarstwami kapitalistycznymi, stosunki z WKP(b), później z KPZR i Związkiem Radzieckim, liczne prace były publikowane w późniejszym okresie w dziełach zebranych publikowanych nie tylko w Chinach, wiele z nich przetłumaczono na inne języki i publikowane w krajach zagranicznych, także w Polsce ${ }^{27}$.

Wielką rolę w rozwoju nie tylko kadr, także pomocy naukowo-teoretycznej dla KPCh odegrała wspomniana już Międzynarodówka Komunistyczna, WKP(b), Związek Radziecki, które wspierały chiński ruch komunistyczny materialnie, kadrowo, a także poprzez kształcenie kadr w szkołach i na uniwersytetach radzieckich. W okresie międzywojennym Związek Radziecki był zwycięskim państwem socjalistycznym, ale leninowska teza o zwycięstwie „światowej rewolucji” nie sprawdziła się i kierownictwo WKP(b) na czele ze Stalinem zdecydowa-

27 Por. Mao Tse-Tung, Dzieła wybrane, t. 1, 2, 3, Warszawa 1953-1954. 
ło się na kontynuację rewolucji i budowę podstaw socjalizmu $\mathrm{w}$ jednym kraju, wielkim, ale osamotnionym, $\mathrm{w}$ dużym stopniu zacofanym i otoczonym przez wrogie państwa imperialistyczne, czekające na stosowną okazję do napaści na pierwsze państwo socjalistyczne i zniszczenia go. W tej sytuacji Związek Radziecki musiał stosować bardzo ostrożną politykę zagraniczną, a jednocześnie w polityce wewnętrznej za wszelką cenę modernizować gospodarkę, głównie budować i modernizować nowoczesne gałęzie przemysłu. Wielkich środków wymagało unowocześnienie sił zbrojnych. Zasadniczej przebudowy wymagało rolnictwo, w którym ilościowo dominowała mało efektywna drobna gospodarka chłopska, a pod względem produkcyjnym wielkie gospodarstwa kułackie. Rodziło to głębokie sprzeczności i groziło załamaniem produkcji żywności, którą to sprzeczność rozwiązano poprzez wprowadzenie kołchozów i sowchozów. Stalin w połowie lat 20. przewidywał, że pokojowe współistnienie $\mathrm{z}$ kapitalizmem może potrwać do piętnastu lat i Związek Radziecki może stanąć w obliczu konfrontacji także wojennej z państwami imperialistycznymi. Niewiele pod tym względem się pomylił, w czerwcu $1941 \mathrm{r}$. hitlerowskie Niemcy napadły na ZSRR (a w grudniu tego roku Japonia na USA) i rozgorzała II wojna światowa.

Sytuacja w międzynarodowym ruchu robotniczym była trudna głównie z powodu jego rozbicia ideowo-politycznego. Partie socjaldemokratyczne przeszły w większości na pozycje oportunistyczne i rewizjonistyczne, w większości dostosowały się do kapitalistycznego ustroju, zrezygnowały z drogi rewolucyjnej i stały się partiami parlamentarnymi, mamiąc świat pracy możliwością przejęcia władzy drogą parlamentarną. Nigdzie teza ta nie została potwierdzona przez praktykę. Jednocześnie kierownictwa partii socjaldemokratycznych nie uznawały Związku Radzieckiego jako państwa socjalistycznego, negując przesłanki rewolucji socjalistycznej, jak i późniejszą 
praktykę gospodarczą i ustrój polityczny. W tej sytuacji Komunistyczna Partia Rosji jeszcze w czasach Lenina przystąpiła do organizowania nowego rewolucyjnego ruchu robotniczego w skali międzynarodowej, przyczyniając się walnie do powstania w 1919 r. III Międzynarodówki, tzw. Międzynarodówki Komunistycznej. Miała ona za zadanie zakładanie nowych partii komunistycznych i tworzenie rewolucyjnego bastionu w ruchu robotniczym, powstały silne partie w Niemczech, Włoszech i Francji, które szybko zostały wyeliminowane po dojściu do władzy w tych pierwszych przez faszystów, także w mniejszych państwach np., w Czechosłowacji, ale perspektywicznie wielkim sukcesem było utworzenie partii komunistycznej w Chinach w 1921 r., a później w Indiach, Indonezji i innych państwach kolonialnych i półkolonialnych ${ }^{28}$.

W tej sytuacji międzynarodowej radziecka droga do rewolucji i budowa socjalizmu w Związku Radzieckim były praktycznie jedynym modelem, który mógł być studiowany i naśladowany przez inne partie komunistyczne. Związek Radziecki, jego przywódcy i doświadczenie WKP(b) cieszyły się wielkim autorytetem w szeregach międzynarodowego ruchu komunistycznego i było to uzasadnione, ale jednocześnie Rosja i ZSRR cechowały się dużą odmiennością rozwoju gospodarczego, historycznego i społeczno-politycznego, które rzutowały na ich odrębność, ale które w ówczesnej sytuacji okrążenia kapitalistycznego były pomijane bądź bagatelizowane. Z czasem jednak dały one o sobie znać w nowej sytuacji politycznej, stając się jedną z przesłanek osłabienia i upadku KPZR i ZSRR pod koniec XX w.

28 Więcej na ten temat zob. Z. Wiktor, Wptyw Rewolucji Październikowej w Rosji na zmiany polityczno-ustrojowe w Azji, [w:] System polityczny i kultura prawna państw azjatyckich, red. J. Marszałek-Kawa, Toruń 2018, s. 9-66. 
Przykład Rosji i jej drogi do rewolucji socjalistycznej był bliski dla marksistów i komunistów chińskich także ze względu na zbliżone warunki społeczno-gospodarcze. Rosja carska była państwem z dużymi pozostałościami feudalizmu, w produkcji przeważała gospodarka rolna, przemysł rozwijał się wyspowo w kilku centrach gospodarczych, udział przemysłu w gospodarce był niewielki, Rosja była morzem chłopów z niewielkim udziałem robotników i zajęć miejskich. Zbliżało to Rosję do Chin, które miały gospodarkę jeszcze bardziej zacofaną niż sąsiad z północy. Chiny do końca cesarstwa, a nawet później były wciąż półfeudalnym i półkolonialnym państwem, w którym dominowała drobna produkcja rolna i tradycyjne cechy społeczeństwa wiejskiego, wspólnot gminnych. Było to wielkim wyzwaniem dla marksistów i komunistów chińskich, którzy dążyli do szybkiej rewolucyjnej przebudowy nie tylko gospodarki, także świadomości społeczeństwa chińskiego ${ }^{29}$.

Podstawowymi cechami tego społeczeństwa były: 1 . Niewielkie społeczności, najczęściej wioska, gmina, gdzie ludzie żyli w na wpół samowystarczalnych gospodarstwach i mieli nieliczne kontakty ze światem zewnętrznym. 2. Były to społeczności o zróżnicowanym modelu, opartym na hierarchicznym zróżnicowaniu ludzi w rodzinach i w zależności od stopnia bogactwa. Każda rodzina zakreślała koło wpływu i w zależności od bogactwa mogła decydować o swych sąsiadach. W skali państwa największy krąg wpływów należał do cesarza. Wpływy te podobne były do wodnych fal. Fei Tong, opierając się na konfucjanizmie okrył przyczynę zróżnicowanych wzorów w społeczności wiejskiej. Stosunki społeczne (konfucjańskie „lun”) są jakby zróżnicowaniem pomiędzy kręgami fal, rozpryskujących się z jednego punktu i łączących się $\mathrm{z}$ innymi falami. Ażeby nie zagubić się w relacjach międzyludz-

29 Por. R. Terrill, Mao, biografia..., op.cit., s. 95 i n. 
kich, wyznawcy Konfucjusza doradzali, by w tych stosunkach odróżniali relacje ojca od syna, bliskość od dystansu, ponieważ stosunki międzyludzkie są „porządkiem” w „różnorodności”. Był to wyraźny priorytet relacji rodzinnych w stosunku do innych. 3. Porządek ten chroniony był dzięki etycznym zasadom konfucjańskim. Był to zbiór norm uznanych przez społeczeństwo jako właściwe i słuszne. Były one podstawą tradycji, ukształtowanej odwiecznym doświadczeniem i powtarzalnością czynności i pór roku. Ludzie wysoko cenili zachowania społeczne, które opisane były w starożytnych sagach Yao i Shuna i które miały moc autorytetu w wypowiedziach. 4. Więzy pokrewieństwa, bardzo bliskie i silne we wspólnocie wiejskiej, będące mocnym spoiwem wspólnoty. Status społeczny wynikał z pokrewieństwa i od urodzenia określał pozycję społeczną jednostki, jej zawód i zamożność. Znalazło to wyraz w powiedzeniu, że synowie urzędników będą zawsze urzędnikami, synowie chłopów - chłopami, robotników - robotnikami, a biznesmenów także biznesmenami. Rodziny i jednostki dziedziczyły pokrewieństwo zawodowe i środowiskowo-klasowe. Świadczyły o tym inne powiedzenia: „Potomkowie arystokracji są nadal szlachetnie urodzonymi” i „Spadkobiercy bogatych są nadal bogatymi". 5. System patriarchalny. Oznaczało to, że społeczeństwo składało się z wielkich i rozrastających się rodzin i klanów, które tworzyły dominujące grupy, będące podstawą systemu patriarchalnego i stosunków feudalnych ${ }^{30}$.

Analiza społeczności wiejskiej w Chinach dokonana przez Fei Xiatonga oparta była na teorii i metodach szkoły funkcjonalnej w socjologii, nie zaś w oparciu o metodę i teorię walki klasowej, charakterystycznych dla materializmu historycznego, ale wskazywała na dużą rolę konfucjanizmu w wiejskich

30 Wyniki badań Fei Xiaotanga, Rural China, Shanghai OBSERVERS' Publishing House, 1948, podaję za: Zhang Hangsheng, Li Yingsheng, Historia chińskiej socjologii, Toruń 2010, s. 278 i n. 
stosunkach jeszcze w latach 40. XX w., który konsekwentnie zwalczany był przez KPCh, a w szczególności Mao Zedonga.

W latach 30. XX w. dla Mao Zedonga autorytet ZSRR i WKP(B) był niepodważalny. W 1938 r. mówił on, że teoria Marksa-Engelsa-Lenina-Stalina jest słuszna dla całego świata. Nie można jej jednak rozpatrywać jako dogmatu, trzeba ją traktować jako wytyczną działania. „Studiowanie marksizmu-leninizmu nie należy sprowadzać do nauczenia się samych formuł, trzeba go studiować jako naukę o rewolucji". Przed KPCh, jak stwierdził Mao, stało wielkie zadanie opanowania teorii marksistowskiej, nasycić nią wszystkich członków partii, a przede wszystkim kierownicze kadry, bez tego partia nie wypełni prawidłowo swej misji rewolucyjnej i budowy socjalizmu ${ }^{31}$. Mao prawidłowo oceniał możliwości adaptacji marksizmu w warunkach chińskich. Uważał, że nie można do niego podchodzić dogmatycznie, marksizm wykształcił się na Zachodzie, w Europie w innych warunkach kulturowych i historycznych, ale KPCh może wykorzystać jego teorię i metodologię. Przed KPCh stoi wielkie zadanie ponownego spojrzenia na chińską spuściznę historyczną, krytycznie ją uogólnić, posługując się jednocześnie metodą marksistowską. Historia narodu chińskiego liczy wiele tysięcy lat, ma ona swe cechy szczególne, jak również niezwykle cenny dorobek. Współczesne Mao Zedongowi Chiny były produktem całego poprzedniego rozwoju kraju, a w latach 30 . XX w. były on owładnięty licznymi sprzecznościami rodzącego się kapitalizmu, jak i licznych pozostałości ustroju feudalnego. KPCh jako partia marksistowska była zwolenniczką materialistycznego pojmowania historii i nie odżegnywała się od przeszłości historycznej. Mao jednak postulował nowe uogólnienie całej chińskiej przeszłości - „od

31 Mao Tse-tung, Pozycja Komunistycznej Partii Chin w wojnie narodowej (październik 1938), [w:] idem, Dzieła wybrane, t. 2, Warszawa 1954, s. 294-295. 
Konfucjusza do Sun Yatsena”, powtarzał, trzeba opanować ten cenny dorobek. „Komuniści są zwolennikami internacjonalnej nauki - marksizmu, jednak marksizm zdołamy wcielić w życie, jeżeli uwzględnimy konkretne cechy szczególne naszego kraju i poprzez określoną formę narodową. Wielka siła marksizmu-leninizmu polega właśnie na tym, że jest on nierozerwalnie związany z konkretną praktyką rewolucyjną każdego konkretnego kraju. Dla Komunistycznej Partii Chin oznacza to, że trzeba nauczyć się stosować teorię marksistowsko-leninowską w konkretnych warunkach Chin, aby we wszystkich swych przejawach niezawodnie odzwierciedlała ona specyficzne cechy chińskie. Innymi słowy, nauczyć się stosować marksizm odpowiednio do właściwości Chin - oto zadanie, jakie cała partia powinna jak najszybciej zrozumieć i spełnić. Trzeba skończyć z zamorskimi szablonami i mniej się zajmować czczą i abstrakcyjną paplaniną. Dogmatyzm trzeba złożyć do archiwum, a przyswoić sobie chiński styl i chińskie zwyczaje, świeże i żywe, przyjemne dla ucha i radosne dla oka ludu chińskiego. Oderwanie internacjonalnej treści od narodowej formy właściwe jest ludziom, którzy absolutnie nie rozumieją internacjonalizmu. Jeśli chodzi o nas, to jesteśmy za ścisłym łączeniem jednego i drugiego. W tym zagadnieniu popełniliśmy poważne błędy, które trzeba zdecydowanie przezwyciężyć"32.

KPCh pod wodzą Mao Zedonga prowadziła nieustanną pracę wyjaśniającą co do celów rewolucji demokratycznej i socjalistycznej, jak i późniejszych zadań budownictwa socjalistycznego. Członkom partii i mieszkańcom wyzwalanych terenów wyjaśniano nie tylko teoretycznie zasady postępowego ustroju, wdrażano je w życie poprzez reformę rolną, likwidację wyzysku obszarników, powszechną naukę dzieci i młodzieży, społeczne wyzwolenie kobiet, usuwanie obyczajowości i religii

32 Ibidem, s. 296. 
konfucjańskiej. „Komunizm to konsekwentna ideologia proletariatu i jednocześnie nowy ustrój społeczny. Są one najbardziej postępowe, najbardziej rewolucyjne i najbardziej rozumne”. Natomiast „Feudalna ideologia i feudalny ustrój społeczny - to muzealny zabytek historyczny" - przekonywał w $1940 \mathrm{r}^{33}$

Droga do powstania socjalizmu prowadzi przez obalenie kapitalizmu. „W ostatecznym rachunku ustrój kapitalistyczny zostanie zastąpiony ustrojem socjalistycznym, jest to obiektywne prawo niezależne od woli ludzkiej. Wbrew wszelkim wysiłkom reakcjonistów, by zatrzymać bieg historii, rewolucja nastąpi wcześniej czy później i nieuchronnie osiągnie zwycięstwo" ${ }^{34}$.

Zdaniem Przewodniczącego rewolucja w Chinach jest procesem długotrwałym i jej złożone zadania realizowane są w ogniu partyzanckiej wojny z wrogami ludu i z pozostałościami ideologii reakcyjnych klas. „Kierowany przez Komunistyczną Partię Chin ruch rewolucyjny jest w swym całokształcie jednolitym ruchem rewolucyjnym, obejmującym i etap rewolucji demokratycznej, i etap rewolucji socjalistycznej. Są to dwa odmienne pod względem swego charakteru procesy rewolucyjne i dopiero doprowadziwszy do końca pierwszy z nich można przystąpić do doprowadzenia do końca drugiego. Rewolucja demokratyczna jest niezbędnym przygotowaniem do rewolucji socjalistycznej, a rewolucja socjalistyczna - nieustannym kierunkiem rozwoju rewolucji demokratycznej. Ostateczny zaś cel wszystkich komunistów polega na tym, aby walczyć z wszystkich sił o ostateczne zbudowanie społeczeństwa socjalistycznego i komunistycznego" ${ }^{\text {"35 }}$.

33 Mao Zedong, O nowej demokracji, styczeń 1940 roku, [w:] Wyjątki $z$ dziet Przewodniczącego Ma o Tse-tunga (Czerwona książeczka), Wrocław 2005, s. 30.

34 Idem, Przemówienie na jubileuszowej sesji Rady Najwyższej ZSRR z okazji 40. rocznicy Wielkiej Socjalistycznej Rewolucji Październikowej (6 listopada 1957 roku), [w:] Wyjątki z dziet..., op.cit, s. 32-33.

35 Idem, Rewolucja chińska i Komunistyczna Partia Chin (grudzień 1939 roku), [w:] Wyjątki z dziet..., op.cit., s. 33-34. 
Rewolucji nie robi się dla samej rewolucji, jest ona obiektywnym procesem społecznym jako sposób na rozwiązanie głębokich sprzeczności społecznych i rodzącego się społeczeństwa socjalistycznego. „Celem rewolucji socjalistycznej jest wyzwolenie sił wytwórczych. Przekształcenie indywidualnej własności w rolnictwie i rzemiośle w socjalistyczną własność kolektywna i przekształcenie własności kapitalistycznej w prywatnym przemyśle i handlu we własność socjalistyczną, Powstaną wówczas warunki społeczne do potężnego rozwoju produkcji przemysłowej i rolnej" ${ }^{36}$. Godne podkreślenia jest, jak podkreślił Przewodniczący Mao, że „obecnie prowadzimy nie tylko rewolucję w ustroju społecznym, to jest przejście od własności prywatnej do własności uspołecznionej, ale prowadzimy i rewolucję w technice, to jest przejście od produkcji rzemieślniczej do nowoczesnej produkcji maszynowej na wielką skalę. Te dwie rewolucje są ze sobą związane"37.

Wielkim zagadnieniem nie tylko teoretycznym, lecz także o ogromnych następstwach praktycznych jest kwestia długości procesu rewolucyjnego, a więc okresu, w którym walka klasowa przebiega z ostrym nasileniem, sprzeczności klasowe przybierają ekstremalny charakter nawet wojny domowej, walka przybiera charakter „kto - kogo” i w której często aktywnie uczestniczą pomocnicy zagraniczni. Ale każda rewolucja rozumiana jako walka o władzę zawsze kiedyś się kończy i rozpoczyna się nowy okres walki o zmianę stosunków własnościowych w środkach produkcji, przede wszystkim w gospodarce. Jak dowodzi historia realnego socjalizmu procesy te były stosunkowo długotrwałe, szczególnie w Rosji, jednocześnie w krajach opóźnionych pod względem rozwoju bazy prze-

36 Idem, Przemówienie na Najwyższej Konferencji Państwowej (25 stycznia 1956 roku), [w:] Wyjątki z dziet..., op.cit., s. 3.

37 Idem, O zagadnieniach uspółdzielczenia rolnictwa (31 lipca 1955 roku), [w:] Wyjątki zdziet..., op.cit., s. 35. 
mysłowej nie wystarcza tylko uspołecznienie dotychczasowej własności kapitalistycznej, państwo socjalistyczne musi zbudować własną socjalistyczną bazę przemysłową, co wymaga znacznie dłuższego okresu. W związku z tym wzrasta znaczenie okresu przejściowego, tj. czasu w którym proletariat zdobył władzę polityczną, ale musi stoczyć walkę z pokonaną politycznie burżuazją, ale dysponującą jeszcze własnością środków produkcji. Mówił o tym Mao Zedong w marcu 1957 r., podkreślając, że walka klasowa w Chinach będzie jeszcze trwać długo tak z uwagi na przyczyny wewnętrzne, jak i zagrożenia zewnętrzne. „Tocząca się w naszym kraju walka o umocnienie ustroju socjalistycznego, walka »kto - kogo« - socjalizm czy kapitalizm - potrwa jeszcze przez długi okres historyczny"38.

Wielką rolę w tej organizacyjnej i ekonomicznej funkcji rewolucji socjalistycznej odgrywa socjalistyczne państwo, które, jak przypomniał Mao Zedong, ,jest państwem demokratycznej dyktatury ludu, kierowanym przez klasę robotniczą i opartym na sojuszu robotniczo-chłopskim. Czemu służy ta dyktatura? Pierwszą jej funkcją jest zdławienie wewnątrz kraju reakcyjnych klas, reakcjonistów i tych wyzyskiwaczy, którzy sprzeciwiają się rewolucji socjalistycznej, zgniecenie tych którzy sabotują nasze budownictwo socjalistyczne... Dyktatura ma i drugą funkcję, a mianowicie obronę państwa przed wywrotową działalnością i możliwą agresją ze strony wrogów zewnętrznych"39.

Chińska Republika Ludowa nie jest państwem dyktatorskim ani autorytarnym, tak jak to często przedstawiają autorzy burżuazyjni. Jest państwem dyktatury proletariatu, w którym władza należy do ludu pracującego, a metody dyktatorskie

38 Idem, Przemówienie na ogólnokrajowej naradzie Komunistycznej Partii Chin, poświęconej pracy propagandowej (12 marca 1957 roku), [w:] Wyjatki z dziet..., op.cit., s. 37.

39 Idem, O właściwym traktowaniu sprzeczności w tonie ludu (27 lutego 1957 roku), [w:] Wyjątki z dziet..., op.cit., s. 51-52. 
stosowane są w stosunku do burżuazji i innych wrogów ludu, natomiast demokracja jest udziałem świata pracy. Kierowniczą siłą tego państwa jest klasa robotnicza, którą kieruje partia komunistyczna. Te relacje Mao Zedong przedstawił w sposób następujący: „Demokratyczna dyktatura ludu potrzebuje kierownictwa klasy robotniczej, ponieważ tylko klasa robotnicza jest najbardziej dalekowzroczna, bezinteresowna i najbardziej konsekwentnie rewolucyjna. Cała historia rewolucji świadczy, że bez kierownictwa klasy robotniczej rewolucja ponosi klęskę, a pod jej kierownictwem rewolucja odnosi zwycięstwo" ${ }^{40}$.

W Chinach stworzono silne podwaliny władzy ludowej i jak podkreślał Mao Zedong: „Podstawą demokratycznej dyktatury ludu jest sojusz klasy robotniczej, chłopstwa i drobnej burżuazji miejskiej, a głównie sojusz robotników i chłopów, ponieważ te dwie klasy stanowią 80-90\% ludności"41. Osią systemy politycznego jest Komunistyczna Partia Chin, która jest centralną siłą kierowniczą, a teoretyczną podstawą określającą cele socjalizmu jest marksizm-leninizm. „Dla dokonania rewolucji niezbędna jest partia rewolucyjna. Bez partii rewolucyjnej stworzonej na podstawie rewolucyjnej teorii marksizmu-leninizmu i opartej na rewolucyjnym marksistowko-leninowskim stylu, nie można doprowadzić klasy robotniczej i szerokich mas ludowych do zwycięstwa mad imperializmem i jego sługusami" ${ }^{42}$. Bowiem bez wysiłku Komunistycznej Partii Chin, bez komunistów chińskich, jako ostoi narodu chińskiego, nie można osiągnąć niezawisłości i wyzwolenia Chin ani nie można osiągnąć uprzemysłowienia Chin i unowocześnienia ich

40 Idem, O demokratycznej dyktaturze ludu (30 czerwca 1949 roku), [w:] Wyjątki z dziet..., op.cit., s. 52-53.

41 Ibidem, s. 53-54.

42 Idem, Rewolucyjne sity całego świata, tączcie się do walki przeciwko imperialistycznej agresji (2 listopad 1948), [w:] Wyjatki z dziet..., op.cit., s. 1-2. 
rolnictwa ${ }^{43}$. Komunistyczna Partia Chin jest nie tylko przewodnią siłą klasy robotniczej, jest kierowniczym trzonem całego narodu chińskiego. Bez takiego trzonu zwycięstwo sprawy socjalizmu jest niemożliwe. KPCh opracowała generalną linię i generalną politykę chińskiej rewolucji, a także określiła konkretne kierunki pracy i wytyczne polityki ${ }^{44}$.

Mao Zedong dużo uwagi poświęcał zagadnieniu walki klasowej, dotyczyło to nie tylko wczesnego okresu rewolucji narodowej, ale także budownictwa socjalistycznego. Uważał, że „walka klas była i jest cechą charakterystyczną dla społeczeństw podzielonych klasowo, jest wyrazem nierozwiązanych sprzeczności między wielkimi grupami społecznymi, które wynikają z własności środków produkcji i nierównego podziału dochodu narodowego. Tak było w historii i tak jest współcześnie. Walka klas, zwycięstwo jednych klas, a zniszczenie drugich - oto ich historia, wielotysięczna historia cywilizacji. W społeczeństwie klasowym każdy człowiek znajduje się w określonej sytuacji klasowej, toteż nie ma takiej ideologii, która by nie nosiła piętna klasowego". Odnosząc kwestię do Chin Mao podkreślał, że „w chińskim społeczeństwie feudalnym tylko ta walka klasowa chłopstwa, tylko te powstania i wojny chłopskie były właśnie prawdziwymi siłami napędowymi rozwoju historycznego" ${ }^{45}$.

Mao twierdzi, że walka narodowa jest także w ostatecznym rachunku walką klasową. W Chinach, choć proletariat przemysłowy dopiero rozwija się na masową skalę, jest on także kierowniczą siłą chińskiej rewolucji. Klasowo kwestia jest bardzo czytelna. Mau uważał, że ten kto zajmuje stanowisko po

43 Ibidem, s. 2.

44 Idem, Przemówienie na naradzie pracowników kadrowych rejonu wyzwolonego Szansi-suijuan (1 kwietnia 1948 roku), [w:] Wyjatki z dziet..., op.cit., s. 8.

45 Idem, Rewolucja chińska a Komunistyczna Partia Chin (grudzień 1938 roku), [w:] Wyjątki z dziet..., op.cit., s. 11. 
stronie rewolucyjnej narodu jest rewolucjonistą. A ten, który stoi po stronie imperializmu, feudalizmu i kapitalizmu biurokratycznego jest kontrrewolucjonistą. „My jako KPCh stoimy na pozycjach proletariatu i szerokich mas ludowych. Dla komunisty oznacza to, że powinien stać na pozycjach partyjnych, na pozycjach partyjności i wierności wobec polityki partii" ${ }^{46}$.

Powstaje pytanie czy nadal istnieje walka klasowa po zwycięskiej rewolucji, jaki ma charakter i czy zmieniają się jej zakres i ostrość. Stalin i Mao Zedong stali na stanowisku, że wraz $\mathrm{z}$ budową socjalizmu walka klasowa nadal istnieje, a nawet w pewnych okresach ma tendencje do nasilania się ze względu głównie na zagrożenia zewnętrzne, np. niebezpieczeństwa agresji i wojny. Może ona zaostrzać się aspekcie wewnętrznym, jeśli kierownictwo partii w porę nie dostrzeże sprzeczności i nie rozwiąże ich. Może być także wynikiem popełnionych błędów, w szczególności w polityce społeczno-ekonomicznej. Historia realnego socjalizmu dostarcza licznych przykładów zaostrzenia walki klasowej na skutek woluntarystycznych błędów kierownictwa. Obecne kierownictwo Chin nie uważa walki klasowej za główną sprzeczność kraju, stoi ono na stanowisku, że główną sprzecznością Chin jest ta między rosnącymi potrzebami narodu a możliwościami ich zaspokojenia, stąd otwarło się na szeroką współpracę z kapitałem krajowym i zagranicznym, co przyniosło spektakularne rezultaty rozwoju i rozwiązanie licznych problemów ekonomiczno-społecznych Chin.

Inaczej na te kwestie patrzył Mao Zedong, który w 1957 r. stwierdził, że walka klasowa w socjalizmie nadal ma miejsce. „W naszym kraju chociaż socjalistyczne przeobrażenia, jeśli mówić o własności, są w zasadzie już zakończone i zakrojone na wielką skalę burzliwe walki klasowe mas, charakterystyczne dla poprzednich okresów rewolucji, w zasadzie dobiegły końca, tym

46 Idem, Przemówienie na naradzie w Jenanie, poświęconej zagadnieniom literatury i sztuki (maj 1942), [w:] Wyjątki z dziet..., op.cit., s. 202. 
niemniej istnieją jeszcze niedobitki obalonych klas obszarników i burżuazji kompradorskiej, istnieje jeszcze burżuazja, a drobna burżuazja dopiero zaczyna się przekształcać. Walka klasowa jeszcze się nie zakończyła...”77. I dalej Mao Zedong: „W naszym kraju ideologia burżuazyjna, drobnoburżuazyjna, ideologia antymarksistowska będą istnieć jeszcze przez długi czas. Ustrój socjalistyczny w naszym kraju jest w zasadzie ustanowiony (...), ale nie osiągnęliśmy jeszcze pełnego zwycięstwa na froncie politycznym i ideologicznym. Problem »kto kogo« między proletariatem a burżuazja w dziedzinie ideologii nie został jeszcze na dobre rozstrzygnięty. Czeka nas jeszcze długotrwała walka przeciw ideologii burżuazyjnej i drobnoburżuazyjnej..." ${ }^{48}$. Dzieje się tak w Chinach, ponieważ „są dwa rodzaje sprzeczności społecznych: sprzeczność między nami a wrogami i sprzeczność w łonie ludu. Żeby poznać ich istotę, trzeba wiedzieć, co to znaczy »lud« a co »wróg« (...) wszystkie klasy, warstwy i grupy społeczne, które aprobują i popierają sprawę budownictwa socjalistycznego i biorą w nim udział, należą do kategorii ludu, podczas gdy wszystkie siły i grupy społeczne, które przeciwstawiają się rewolucji socjalistycznej (...) są wrogami ludu"49.

Ta skrótowa analiza wypowiedzi Mao Zedonga na temat teorii i metodologii marksizmu-leninizmu, jego podstawowych zasad i kategorii pozwala stwierdzić, że miał on fundamentalne znaczenie w zakresie przeniesienia na grunt chiński marksizmu-leninizmu. Jednocześnie dostosowywał go i rozwijał odpowiednio do warunków i rozwoju społeczno-gospodarczego, kulturowego, cywilizacyjnego i historycznego Chin. Bez wątpienia Mao

47 Idem, O właściwym traktowaniu sprzeczności w tonie ludu (27 lutego 1957 roku), [w:] Wyjątki z dziet..., op.cit., s. 22-23.

48 Idem, Przemówienie na ogólnokrajowej naradzie Komunistycznej Partii Chin poświęconej pracy propagandowej (12 marca 1957 roku), [w:] Wyjatki z dziet..., op.cit., s. 25-26.

49 Idem, O właściwym traktowaniu sprzeczności w tonie ludu (27 lutego 1957 roku), [w:] Wyjątki z dziet..., op.cit., s. 60-61. 
Zedong był nie tylko wielkim teoretykiem marksizmu, także wybitnym przywódcą chińskiego ludu, który przewodząc odrodzonej Komunistycznej Partii Chin potrafił skierować Chiny na drogę rewolucji demokratycznej i socjalistycznej, która zakończyła się wielkim zwycięstwem w 1949 r. Jednocześnie wraz z powstaniem Chińskiej Republiki Ludowej przez prawie trzydzieści lat stał na czele socjalistycznych Chin i kierował budową podstaw ustroju socjalistycznego. W końcowej części życia popełnił pewne błędy, które jednak nie przekreślają jego wielkich zasług jako rewolucjonisty i twórcy socjalizmu w Chinach. Był także wybitnym marksistą, który nie tylko przyswoił główne treści marksizmu na grunt chiński, ale wzbogacił go o treści rodzimej kultury, które znalazły wyraz w powstaniu maoizmu jako odrębnego, nowatorskiego nurtu marksizmu, czerpiącego z postępowych chłopskich tradycji walk klasowych w Chinach, co początkowo zbliżało go do tzw. „socjalizmu agrarnego”. Z tych, powodów można stwierdzić, że Mao Zedong był dla Chin tym czym dla Rosji i ZSRR byli razem Lenin i Stalin. Jednocześnie KPCh pod jego kierownictwem potrafiła w bardzo trudnych warunkach międzynarodowych i wewnętrznych obronić dziedzictwo rewolucyjnego marksizmu i międzynarodowego ruchu komunistycznego w sytuacji postępującej erozji prawicowego rewizjonizmu i oportunizmu w KPZR po śmierci Stalina ${ }^{50}$.

\section{Budowa podstaw socjalizmu w Chinach w okresie przywództwa Mao Zedonga (1949-1976)}

Okres ten obejmuje ponad 25 lat, które cechowały się licznymi napięciami wewnętrznymi i międzynarodowymi. Rewo-

50 O pozycji i roli Mao Zedonga w historii Chin, głównie w XX w. zob. fundamentalne dzieło autora rosyjskiego Aleksandra Pancova, Mao Czedun, Moskwa 2007, s. 6-868; zob. też: F.M. Burłackij, Mao Czedun, Moskwa 2003, s. 5-255. 
lucja 1949 r. zniosła panowanie burżuazji oraz obszarników i wprowadziła państwo socjalistyczne, które znosiło własność prywatną środków produkcji i wprowadzało uspołecznione, socjalistyczne formy własności. Jednocześnie nowa socjalistyczna władza, korzystają z pomocy Związku Radzieckiego i innych państw socjalistycznych rozpoczęła realizację nowej bazy gospodarczej, głównie przemysłowej, budowę dróg i mostów na wielkich rzekach, wdrożyło budowę nowych linii kolejowych i modernizację kraju. Jednocześnie okres ten znamionowany był wielkimi napięciami międzynarodowymi, które zaostrzyły się w czerwcu 1950 r. wraz z wybuchem wojny w Korei, w której Chińska Republika Ludowa stanęła po stronie Koreańskiej Republiki Ludowo-Demokratycznej, udzielając jej pomocy wojskowej i ekonomiczno-finansowej. Już na starcie Chiny ludowe stanęły w obliczu klasowej konfrontacji z imperializmem, co położyło się dużym cieniem na stosunkach z państwami kapitalistycznymi, głównie z USA, które w walce z socjalizmem przeszły od zimnej do gorącej wojny. KPCh w okresie tym wdrożyła i realizowała szeroki program przemian społecznych i gospodarczych. Na wzór radziecki wdrożono centralne planowanie w gospodarce, realizowano pierwsze plany 5-letnie, które nastawione były na odbudowę zniszczonej przez wojnę gospodarki, jak i wznoszenie nowych inwestycji. Wdrażano nowe technologie i metody pracy, podnoszono wydajność pracy. Procesom tym sprzyjał centralizm w zarządzaniu nie tylko gospodarką, ale w całym państwie, oparty na zasadzie centralizmu demokratycznego. Główną siłą polityczną była Komunistyczna Partia Chin, która rozwijała demokrację partyjną i państwową. Program przemian demokratycznych i socjalistycznych cieszył się powszechnym poparciem ludzi pracy, a jednocześnie budził opór nie do końca przezwyciężonych sił konserwatywnych, w tym żywego jeszcze w licznych środowiskach konfucjanizmu. Ogrom zadań i trudności, przed jakimi stanęły ludowe Chiny 
wymagał wysokiego stopnia zdyscyplinowania społeczeństwa i konsekwencji w realizacji postawionych zadań.

Centralizacja zarządzania była na swój sposób ułatwiona przez wielowiekową egzystencję władzy cesarskiej, wysoce autorytarnej, zarządzanej w sposób scentralizowany, którego zwieńczeniem była osoba cesarza, cieszącego się nie tylko autorytetem politycznym, także „niebiańską świętością”, jak to uzasadniała tradycja konfucjańska tak filozoficzna, jak religijna. Część autorów burżuazyjnych opisujących stosunki w otoczeniu Mao Zedonga, np. dr Li Zhishu (lekarz osobisty Przewodniczącego), biorąc pod uwagę potężny zakres jego władzy, autorytet, jakim się cieszył wśród Chińczyków i jego relacje z podwładnymi, niejednokrotnie przedstawiały go jako „nowego cesarza”, który daleki był w swych zwyczajach od oficjalnie głoszonych zasad skromności i szacunku wobec w szczególności kobiecego personelu kancelarii $\mathrm{Mao}^{51}$.

Rewolucja demokratyczna i socjalistyczna, która zwyciężyła w Chinach obaliła system rządów burżuazji i jej zagranicznych sojuszników, znosiła także pozostałości wcześniejszych feudalno-obszarniczych instytucji i porządków, ale droga do wprowadzenia demokratycznego, ludowego i socjalistycznego społeczeństwa była daleka i przebiegała nie bez trudności ze względu na ogólne zacofanie gospodarcze i społeczne Chin, pozostawione przez poprzednie epoki. Od wielu lat toczyła się wojna domowa, wcześniej z Japończykami, w prowincjach przygranicznych, w których były silne mniejszości narodowe, szerzył się separatyzm. Dopiero w latach 1955-1956 wyzwolony został Tybet, w 1945 r. przepędzeni zostali Japończycy, ale w 1950 r. wybuchła wojna w Korei, trwająca trzy lata i do której po stronie KRLD z powodów internacjonalistycznych i geostrategicznych przystąpiła Chińska Republika Ludowa,

51 Zob. w szczególności: Li Zhisui, Prywatne życie Przewodniczącego Mao, Warszawa 1996, s. 332 i n. 
co było dużym obciążeniem wojskowym i ekonomicznym. Wojna w Korei przedłużyła stan wojenny, w jakim od wielu lat znajdowały się Chiny. Dopiero w 1954 r. ChRL przystąpiła do pokojowego etapu rozwoju, w tym roku uporządkowano kwestie kierowania państwem i wprowadzono pierwszą tzw. prowizoryczną konstytucję, opartą na programie zjednoczonych sił patriotycznych i socjalistycznych. W 1955 r. przystąpiono do realizacji pierwszego planu 5-letniego.

Pomocny w realizacji centralnego planowania i scentralizowanego systemu zarządzania państwem był tradycyjny, ukształtowany jeszcze w czasach cesarskiej państwowości system państwowości, którego osią była pionowa, wertykalna organizacja, oparta na ścisłym podporządkowaniu niższych struktur wyższym aż do rządu centralnego, na czele którego w dawnych epokach stał cesarz i jego urzędnicy. W okresie walk o władzę z Kuomintangiem na czele z Czang Kajszekiem komuniści zdobywali sobie coraz większe poparcie wyzyskiwanej biednej ludności, głównie wiejskiej, jednocześnie opanowywali coraz większe połacie Chin, tworząc na nich podstawy władzy ludowo-socjalistycznej, nawiązując do wzorów i rozwiązań Związku Radzieckiego (okręgi radzieckie). Jednocześnie Kuomintang osłabiony był, a nawet rozdzierany przez spory wewnętrzne i brak szerokiego poparcia społecznego. Jednak cieszył się poparciem USA i międzynarodowej finansjery, dążących do utrzymania w Chinach statusu półkolonialnego. Walka ta jak wiadomo trwała przez wiele lat i dopiero w 1949 r. udało się Chińskiej Armii Ludowo-Wyzwoleńczej opanować zdecydowaną większość kraju, a Czang Kajszek z resztkami swych sił musiał szukać schronienia na okupowanym od 1945 r. przez wojska USA Tajwanie i korzystając z ich pomocy ustanowił tam kontynuację rządów Republiki Chińskiej ${ }^{52}$.

52 R. Terrill, Mao..., op.cit., s. 222 i n. 
Okres 1953-1976 był czasem wielkich przemian ustrojowych, kiedy powstawały zręby polityczno-ustrojowe i gospodarcze Chińskiej Republiki Ludowej, ale był to także czas licznych wstrząsów i załamań, których główną przyczyną był ogrom wyzwań, trudności i barier, przed którymi stanęła młoda socjalistyczna władza. Jednocześnie dawały o sobie znać błędy w procesie decyzyjnym, brak doświadczenia, luki w prawidłowym rozeznaniu sytuacji gospodarczej i politycznej. Jednocześnie w kierownictwie KPCh pojawiły się różne frakcje, wyrażające rodzące się różne interesy środowiskowe, polityczne i ideologiczne. Odradzały się tendencje biurokratyczne, mające w Chinach wielkie tradycje, choć oficjalnie partia je negowała i potępiała, niektórzy działacze szczególnie terenowego szczebla chętnie korzystali z przywilejów władzy. Nieoficjalnie i podskórnie dawały o sobie znać zwyczaje czerpiące z tradycji konfucjańskich (np. tzw. „prezenty”) i choć partia oficjalnie je potępiała i zwalczała, stawały się coraz większym problemem politycznym i prawnym.

W Chinach wielką rolę odgrywały resorty siłowe, wojsko, policja, służba bezpieczeństwa, różne inne formy administracyjnej organizacyjnej kontroli i ewidencji, ale przede wszystkim armia, która od czasu walki z Kuomintangiem i Japończykami zdobyła wielki autorytet wśród ludu, stała się wielką siłą organizacyjną i militarną, chroniącą nie tylko państwo i naród przed wrogiem zewnętrznym, ale także mającą wielkie znaczenie w utrzymaniu porządku wewnątrz kraju. Nie bez powodu Mao Zedong przypominał stare powiedzenie, że „karabin rodzi władzę (politykę)". Jak zawsze w takich przypadkach chodzi o cywilną kontrolę nad armią, a w państwie socjalistycznym o kontrolę partii komunistycznej nad wojskiem. Mao Zedong mógł nie pełnić innych ważnych funkcji, ale zawsze zabiegał, by być przewodniczącym Centralnej Komisji Wojskowej, zapewniającej mu polityczne kierownictwo nad armią. O tym, 
że kwestia ta miała nie tylko charakter teoretyczny świadczyły późniejsze wydarzenia z okresu tzw. „wielkiej proletariackiej rewolucji kulturalnej", kiedy chińska armia pod dowództwem marszałka Lin Biao (wtedy drugiej postaci w partii i państwie) wyrosła nie tylko na wielką siłę zbrojną kraju , ale także wyrażała silne dążenia polityczne, zagrażające kierownictwu partyjno-politycznemu Mao Zedonga. Wtedy wielkim problemem było, w jakim kierunku pójdą dalej Chiny, czy w kierunku daleko posuniętej urawniłowki i koszarowego socjalizmu, czy w kierunku socjalistycznej gospodarki rynkowej.

Innym wielkim błędem tych lat był tzw. Wielki Skok z lat 50. XX w., który w swych założeniach miał doprowadzić po kilku latach do podwojenia produkcji przemysłowej, głównie w zakresie przemysłu ciężkiego, np. wytapiania żelaza i stali, co przy ówczesnym zacofaniu technologicznym i brakach nowoczesnych urządzeń metalurgicznych okazało się niewykonalne. Podjęte próby uruchomienia produkcji żelaza w wiekowych dymarkach okazało się niewypałem i obnażyły woluntaryzm w kierowaniu ekonomiką. W efekcie zamiast wzrostu produkcji przynosiły wielkie straty nie tylko $\mathrm{w}$ przemyśle, także $\mathrm{w}$ rolnictwie, gdyż do pracy w dymarkach zapędzono olbrzymie rzesze ludności wiejskiej, której zabrakło do niezbędnych prac rolniczych, co skutkowało wielkim spadkiem produkcji rolnej, a w konsekwencji głodem dla milionów nie tylko chłopskich rodzin. W efekcie partia musiała wycofać się z tej awanturniczej polityki, ponosząc duże straty nie tylko materialne, także utraty autorytetu, co rzutowało także na osłabienie jedności ideowo-politycznej kierownictwa i powstanie opozycji, którą Mao Zedong i jego grupa konsekwentnie zwalczała ${ }^{53}$.

Wymienione błędy w kierowaniu państwem i gospodarką, prowadzące do wielkich wstrząsów a nawet załamań, były od-

53 Z. Wiktor, Chiny na drodze socjalistycznej modernizacji, Toruń 2008, w szczególności część napisana przez prof. M. Rakowskiego, s. 266 i n. 
zwierciedleniem wielkich problemów kraju, który wszedł na drogę budownictwa socjalistycznego z niesłychanie niskiego poziomu rozwoju sił wytwórczych, głównie przemysłu i faktycznie wobec braku własnej klasy robotniczej, proletariatu przemysłowego, który w 1949 r. liczył tylko ok. 3 mln robotników w kilku wielkich miastach. Pozostała ludność to olbrzymie morze biednego chłopstwa i proletariackiej nędzarskiej wsi. Do 1949 r. chińskie miasta miały charakter centrów administracyjnych, kupieckich i rzemieślniczych. Chiny szczyciły się wielką cywilizacją i kulturą, ale w 1949 r. 90\% Chińczyków było analfabetami, a język i kultura mandaryńska były udziałem niewielkiej grupy ludności. W tej sytuacji państwo ludowe stanęło przed wielkim wyzwaniem aspiracji nie tylko kulturalnych mas chłopskich i proletariackich, ale przede wszystkim poprawy ich warunków bytowych, co legło u podstaw restrykcyjnego egalitarnego ustroju w zakresie spożycia, którego odzwierciedleniem była zasada „żelaznej miski ryżu”, jako minimum spożywczego dla każdego Chińczyka. Była to sprzeczność, której nie udało się rozwiązać poprzez konfiskatę i uspołecznienie (upaństwowienie) prywatnej własności środków produkcji, której nie było tak wiele, nawet po uwzględnieniu własności kapitału zagranicznego.

W tej sytuacji Chiny stanęły przed wielkim problemem konieczności wzniesienia własnej bazy nowoczesnej gospodarki, głównie przemysłowej i modernizacji kraju w oparciu o własne bardzo ograniczone środki. Podstawową zasadą było liczenie na własne siły, które ze względu na wysoki potencjał ludnościowy przynosiły oczekiwane rezultaty, ale w ograniczonym zakresie. Ważnym elementem przyspieszającym rozwój była pomoc innych krajów socjalistycznych, głównie Związku Radzieckiego. Jednocześnie wojna w Korei, restrykcje i embargo USA i innych państw kapitalistycznych izolowały i ograniczały możliwości rozwojowe przy pomocy współpracy zagranicznej. 
W tej sytuacji Chiny znalazły się pod silnym ciśnieniem wzrostu potrzeb rozwojowych i konsumpcyjnych własnego społeczeństwa, rozbudzonych przez aspiracje socjalistyczne, które m.in. rezultowały próbami szybkiego „przechodzenia na skróty” do komunizmu (określenie prof. Mieczysława Rakowskiego $)^{54}$, a zakończyło się katastrofą Wielkiego Skoku i „rewolucji kulturalnej”, co w sumie przyniosło straty liczone w gospodarce na ok. dziesięć lat.

Jednocześnie te straty i doświadczenia uświadomiły części kierownictwa KPCh, m.in. Deng Xiaopingowi, że Chiny muszą iść inną, własną drogą do socjalizmu niż ZSRR i państwa demokracji ludowej w Europie. Chiny muszą się otworzyć na zewnątrz, wykorzystać swój olbrzymi potencjał siły roboczej i zdecydować się na napływ kapitału zagranicznego, ale na własnych warunkach i przy kontroli własnego państwa, respektowaniu chińskiego systemu prawnego i utrzymania samodzielności chińskiej waluty. Koncepcja ta bardzo podzieliła kierownictwo, rozpoczęła się bezpardonowa walka frakcyjna, nie obeszło się bez pewnego odrodzenia neokonfucjanizmu a obie strony zarzucały sobie uleganie jego wpływom i argumentacji. Musiało upłynąć jeszcze wiele lat, zanim te projekty zmian polityki wewnętrznej i zagranicznej wdrożone zostały do praktyki gospodarczej i politycznej ChRL. Faktycznie były one wprowadzane dopiero po śmierci Mao Zedonga w 1976 r. i dopiero od 1978 r. chińska gospodarka przeszła na inne tory rozwojowe, przy czym nie była to zmiana strategii (socjalizm i komunizm), lecz taktyki, czyli metod dochodzenie do tych celów.

Powracając do ogólnej oceny okresu 1955-1978 trzeba wskazać na główne wskaźniki wzrostu Chin. Przede wszystkim nastąpił olbrzymi przyrost ludności z 600 do 970 mln ludzi,

54 M. Rakowski, Przemiany i szanse socjalizmu (w konfrontacji z kapitalizmem od czasów Marksa po bliska przyszłość), Warszawa 2004, s. 88. 
co potwierdziło także doświadczenie demograficzne innych państw tzw. Trzeciego Świata, które weszły na drogę niepodległości, np. Indii, Indonezji, Pakistanu, krajów afrykańskich w szczególności Nigerii. W Chinach sytuacja żywnościowa była lepsza niż w innych państwach, co pozwoliło uniknąć klęski głodu, podaż żywności była większa niż minimalne potrzeby, co pozwoliło w miarę sprawiedliwie racjonowanie żywności. Produkcja zbóż wzrosła z 250 do 310 kg na mieszkańca, ale nie ustrzegło to całkowicie Chin przed nędzą, którą w 1955 r. zagrożone było 50\% ludności, a w 1978 r. 25\%, głównie na wsi, co oznaczało, że przy ogromnym wzroście liczby ludności w 1978 r. nadal zbliżona liczba mieszkańców znajdowała się w nędzy.

Produkcja mięsa wzrosła trzykrotnie, ale oznaczało to tylko średnio 9 kg spożycia na jednego Chińczyka. Większy był wzrost produkcji przemysłowej, w tym także nawozów sztucznych i innych środków produkcji rolnej. W 1978 r. wydobycie węgla wyniosło $618 \mathrm{mln} \mathrm{t}$, ropy naftowej $100 \mathrm{mln} \mathrm{t}$, stali $32 \mathrm{mln} \mathrm{t}$, cementu $65 \mathrm{mln} \mathrm{t}$, nawozów sztucznych - 8,7 mln t, tkanin - 11 mld m, energii elektrycznej - 259 mld kWh. Oznaczało to znaczny postęp w rozwoju produkcji przemysłowej na mieszkańca, ale w porównaniu ze średnią światową, nie mówiąc o państwach rozwiniętych, Chiny pozostawały bardzo zacofane. Dla przykładu, ludność Chin w 1978 r. wynosiła 22\% ludności świata, a ich produkcja stali w skali światowej wynosiła $5 \%$, cementu $9 \%$, nawozów sztucznych $9 \%$, papieru $3,7 \%$, energii elektrycznej 3,6\%, tkanin bawełnianych na mieszkańca w 1978 r. wytwarzano $11 \mathrm{~m}$, wełnianych 0,4 m, podczas gdy np. w Polsce w tym czasie odpowiednio $28 \mathrm{~m}$ i 3,8 $\mathrm{m}^{55}$.

Schyłkowy okres życia Mao Zedonga to jednocześnie osłabienie jego autorytetu politycznego i pozycji w KPCh. W partii

55 Dane podaję za M. Rakowskim, przytoczone w pracy Zbigniewa Wiktora, Chiny na drodze socjalistycznej modernizacji, Toruń 2008, s. 270. 
powstało kilka frakcji, różniących się co do oceny przeszłości, jak i perspektyw dalszych dróg budownictwa socjalizmu w Chinach. Na to nakładały się różnice ideowo-polityczne w międzynarodowym ruchu komunistycznym, w szczególności głębokie podziały między KPCh a KPZR na tle stosunku do imperializmu, kapitalizmu i perspektyw socjalizmu. Na początku lat 60 . XX w. nastąpiło zerwanie przyjaźni i współpracy między obu partiami, co miało negatywne następstwa na rozbicie międzynarodowego ruchu komunistycznego i robotniczego i na stosunek do kapitalizmu. W KPZR i ZSRR zwyciężyło skrzydło neorewizjonistyczne i oportunistyczne, które w dalszych latach doprowadziło do upadku KPZR i ZSRR głównie za sprawą działalności Gorbaczowa i Jelcyna i co okazało się wielkim osłabieniem, a nawet ciosem w sprawę światowego ruchu robotniczego i komunizmu, a jednocześnie wzmocniło kapitalizm.

W Chinach w okresie rewolucji kulturalnej sprawa walki z pozostałościami Konfucjusza stała się ponownie aktualna. W czasie kampanii skierowanej przeciwko marszałkowi Lin Biao i jego frakcji w gazetach wielkich hieroglifów posługiwano się argumentami, że walka z Lin Biao zatacza coraz szersze kręgi i partia powinna demaskować także innych zwolenników Konfucjusza w kierownictwie Partii i we władzach lokalnych. W 1975 r. w dalszym ciągu prowadzono kampanię przeciwko Lin Biao i Konfucjuszowi. Na sesji parlamentu ChRL w styczniu 1975 r. jednym z punktów obrad była kwestia nowej konstytucji. Referat na ten temat wygłosił członek Biura Politycznego KC KPCh Czang Czun-ciao, który m.in. powiedział, że „W niektórych zakładach pracy tylko formalnie istnieje socjalistyczny system własności, a w rzeczywistości władza kierownicza nie znajduje się w rękach szerokich rzesz robotników". I dalej: „Wiele odcinków, jeśli nie opanuje ich proletariat, to opanuje burżuazja, Dziadyga Konfucjusz zmarł dwa tysią- 
ce lat temu, ale jeśli proletariat nie wymiecie tych śmieci, to same one nie znikną". W związku z tym, jak stwierdził mówca, należy „kontynuować i pogłębiać kampanię krytyki Lin Biao i Konfucjusza"56.

O tym, jak złożona była w latach 70. sytuacja ideowo-polityczna w KPCh świadczą także inne fakty. Mao jak wiadomo uchodzi za klasyka chińskiego marksizmu. Jednocześnie rozwijał on marksizm odpowiednio do chińskich warunków, np. uważając klasę robotniczą i jej ideologię za wiodący czynnik walki klasowej. Uznał, że w warunkach chińskich główną siłą antyfeudalną i antykapitalistyczną może stać się biedne chłopstwo i wiejski proletariat, co okazało się pozytywną przesłanką odbudowy KPCh po 1927 r. oraz poprowadzenia jej do rewolucyjnej walki, i co po ponad dwudziestu latach przyniosło KPCh zwycięstwo, w 1949 r. powstała Chińska Republika Ludowa. Bez wątpienia Mao Zedong był wielkim przywódcą chińskiej rewolucji i jego wielką zasługą było skierowanie Chin na nową drogę rozwoju, która doprowadziła je do rewolucji demokratycznej i socjalistycznej, a w dalszej kolejności na drogę budowy podstaw socjalizmu. Jednocześnie ze względu na odmienność cywilizacyjną Chin, ogromne opóźnienia w rozwoju gospodarczym i zacofaną strukturę społeczną nie mógł on zastosować kategorii marksistowskich powstałych w realiach Europy Zachodniej, czy nawet Rosji radzieckiej, mógł przejąć teorię i metodologię marksistowską głównie w postaci materializmu historycznego i dialektycznego. Jednocześnie chińscy marksiści, głównie w szeregach KPCh, musieli stworzyć bardziej szczegółowe chińskie kategorie naukowe, odzwierciedlające chińskie realia gospodarcze, polityczne i społeczne. Historia walk rewolucyjnych w Chinach wyniosła jako głów-

56 Cyt. według: M.I. Sładkowskij et al. (red.), Najnowsza historia Chin..., op.cit., s. 717,728 . 
ną siłę rewolucyjną biedne chłopstwo i proletariat wiejski, co zbliżało ją do koncepcji „socjalizmu agrarnego”. W efekcie to rewolucyjna wieś otoczyła miasto i przeprowadziła rewolucję demokratyczną i socjalistyczną. Nie bez powodów koncepcja ta i program KPCh uznawany jest jako oryginalna droga, niekopiująca innych modeli, co stało się powodem stwierdzenia, że w Chinach zwyciężył nie marksizm, lecz maoizm. Bez wątpienia chińska rewolucja wyrosła na innym gruncie ekonomiczno-społecznym niż w Europie Zachodniej, nawet w Rosji i ZSRR, do których rozwiązań (marksizmu-leninizmu) z różnych powodów Mao i KPCh chętnie korzystał, szczególnie do lat 60. XX w.

Potwierdzeniem odmienności powstawania i rozwoju „chińskiego marksizmu” jest analiza tekstologiczna głównych prac Mao Zedonga, z których podstawowe stwierdzenia przytoczone zostały poprzednio. W latach 60 . XX w. przeprowadzono analizę tekstologiczną oryginalnego chińskiego wydania Dzieł Zebranych Mao Zedonga. Wynikało z niej, że 22\% wszystkich cytatów, którymi Mao posługiwał się, było zaczerpniętych z prac filozofów konfucjańskich lub neokonfucjańskich, 12\% były to cytaty z prac mohistów lub taoistów, 13\% - odsyłacze do chińskiej literatury pięknej, 4\% - odsyłacze do prac Marksa i Engelsa, 18\% - odsyłacze do prac Lenina, 24\% - odsyłacze do prac Stalina, $7 \%$ - odsyłacze do innych prac ${ }^{57}$. Jak widać Mao najrzadziej korzystał z prac Marksa i Engelsa. Wielkim autorytetem był dla niego Lenin, ale najwięcej korzystał z prac Stalina, z którym znał się osobiście, spotykał się z nim jako polityk i dyskutował. Stalin był dla Mao wielkim autorytetem nie tylko jako polityk, także

57 V. Holubnychy, Ma Tse-tung's Materialistic Dialectics, „The China Quarterly”, lipiec-sierpień 1964, nr 19, s. 17. Cyt. za: M.I. Sładkowskij et al. (red.), Najnowsza historia Chin..., op.cit., s. 703, przypis. Te dane potwierdzone zostały później przez dwóch autorów radzieckich, zob. M.L Słutajski, W.G. Gieorgijew, Antimarksistskaya sucznost' fifosowskich wzgladow Mao Tse-tunga, Moskwa 1969, s. 50-51. 
jako teoretyk i marksistowski ideolog. Uważał, że nowe kierownictwo na czele $\mathrm{z} \mathrm{N}$. Chruszczowem dopuściło się zafałszowania dorobku Stalina nie tylko jako wybitnego męża stanu ZSRR i międzynarodowego ruchu robotniczego (komunistycznego), ale także jako wybitnego marksisty-leninowca.

W następstwie rewolucji kulturalnej ChRL wkroczyła w okres dużej destabilizacji nie tylko ideowo-politycznej, ale także gospodarczej. Jak wspomniano w rezultacie Wielkiego Skoku i rewolucji kulturalnej utraciły ok. dziesięciu lat, co spowodowało wzrost niezadowolenia społecznego i podkopało zaufanie mas do partii. Napięcia temu towarzyszące ożywiły różnice w samej partii, pojawiły się różnice w poglądach, formułowano różne drogi wyjścia z kryzysu, a nawet pojawiły się frakcje, z których najgroźniejsza dla przyszłości partii była „frakcja wojskowych” na czele z marszałkiem Lin Biao, jej główny antagonista - „frakcja pragmatyków” na czele z Deng Xiaopingiem. Mao Zedong i jego grupa lawirowali między frakcjami i starali się łagodzić sprzeczności, a w momentach krytycznych przechodzili na stronę większości. Na początku lat 70. największym zagrożeniem była frakcja Lin Biao, która ostatecznie została rozbita w 1971 r., a jej przywódca poniósł śmierć w niewyjaśnionych do dziś okolicznościach. W trakcie tej kampanii przeciwnicy Mao zarzucali mu m.in. „despotyczne, cesarskie metody sprawowania władzy". Z tego okresu pochodzi dokument pt. „Zarys projektu 571”, mający charakter platformy politycznej tej frakcji, upubliczniony przez tajwański wywiad po śmierci Lin Biao. W dokumencie tym poddana została ostrej krytyce dotychczasowa polityka KPCh pod kierunkiem Mao Zedonga, któremu zarzucono liczne błędy polityczne i gospodarcze, które - zdaniem autorów - doprowadziły kraj na granice katastrofy. Jedynym wyjściem z kryzysu miało być wyeliminowanie Mao i jego grupy oraz wyprowadzenie KPCh i kraju z głębokiego kryzysu. W konkluzji dokumentu 
stwierdzono, że Mao Zedong nie był prawdziwym marksistą-leninowcem, tylko wielkim tyranem feudalnym, fałszywym marksistą, kroczącym nie drogą marksizmu tylko drogą Konfucjusza i Meng-tsy. „Rządził” według praw godnych cesarza Szy Huang-ti z dynastii Cin (Qing). W rzeczywistości, głosił dokument: „Mao Tse-tung stał się nowym cesarzem”58.

Trudno jest jednoznacznie stwierdzić czy ten dokument frakcji Lin Biao był autentyczny, czy też okazał się „podróbką" maoistowskich służb specjalnych, spreparowany w celu skompromitowania opozycyjnej grupy. Faktem jest, że wtedy w Chinach toczyła się walka frakcyjna, która nie tylko miała charakter rywalizacji i walki o władzę, ale odzwierciedlała inną koncepcję budowy socjalizmu, która w kilka lat później wystąpiła w całej okazałości pod hasłem „socjalistycznej gospodarki rynkowej”, której przywódcą stał się Deng Xiaoping. Była to jedna z przyczyn rozpoczęcia w 1973 r. kontrkampanii KPCh pod hasłem „krytyki Konfucjusza”, która zmierzała do „wybielenia” Mao Zedonga i zdjęcia z niego zarzutów przeciwników politycznych, a jednocześnie do krytyki zachowań i postaw wśród części działaczy partyjnych i państwowych stosowania praktyk biurokratycznych i „odrywania się od mas”. Walka z konfucjanizmem zmierzała także do przezwyciężenia licznych przyzwyczajeń, wzorów zachowania, wartości czerpiących z niego, które stały w opozycji do ustroju socjalistycznego i kultury politycznej nowego systemu.

Bez wątpienia rewolucja socjalistyczna w Chinach zmiotła stare feudalno-cesarskie i burżuazyjno-obszarnicze państwo. Ale rewolucja była dziełem mniejszości, komuniści i ich sojusznicy ustanowili nowe państwo, które swym demokratycznym ustrojem i socjalistycznym egalitaryzmem zdobywało

58 M.I. Sładkowskij et al. (red.), Najnowsza historia Chin..., op.cit., s. 637. Tę opinię potwierdzał, o czym wcześniej wspomniano, Li Zhisui, Prywatne życie Przewodniczącego Mao..., op.cit., s. 357 i n. 
sobie sympatię i poparcie mas. Ale jednocześnie społeczeństwo to w większości ciągnęło za sobą stare przyzwyczajenia i nawyki, a także wartości czerpiące z poprzednich formacji. W Chinach ciągle duży wpływ w tym czasie odgrywała ideologia i religia konfucjanizmu, stąd też można stwierdzić, że znajdowało się ono pod ogromnym wpływem, a nawet naciskiem konfucjańskich tradycji.

Pod względem ideowym ta presja przeszłości zawierała w sobie treści i wartości zróżnicowane pod względem ideowym, np. utrwalała ona pewne pozytywne cechy wzorca osobowego, takie jak pracowitość, skromność, wytrwałość i zamiłowanie do wiedzy. Konfucjanizm ułatwiał zdolność przystosowania się, działał na rzecz postawy minimalizacji potrzeb materialnych, a także uczył życiowego konformizmu, co pozwalało przetrwać nawet w najtrudniejszych warunkach. Jednocześnie presja tradycji umacniała w świadomości mas przeświadczenie o wyjątkowej doskonałości cywilizacji chińskiej i o niepodważalnej genialności dawnych mędrców lub władców, w ciągu wieków utrwalała ona silne poczucie hierarchii społecznej, ograniczała swobodę myślenia, inicjatywę i energię jednostek. Stymulowała kiedyś lekceważący stosunek do techniki i niezbędności jej dalszej modernizacji oraz innowacji. Konfucjańska tradycja nie sprzyjała kształtowaniu takich cech osobowości, jak przedsiębiorczość, rzutkość, pomysłowość, natomiast bardzo mocno wiązała ona człowieka z odległą przeszłością historyczną, co odciągało człowieka od problemów teraźniejszych i perspektywicznych.

Złożoność i zmienność historyczna konfucjanizmu i jego różnych szkół powodowała, że ocena systemu filozoficznego Konfucjusza stanowiła jeden z najtrudniejszych, a jednocześnie najbardziej spornych problemów na gruncie marksistowskiej humanistyki. Część historyków skupiła się na racjonalnych i postępowych treściach konfucjanizmu, jak np. profesor Kuo Mo-żo (b. prezes Chińskiej Akademii Nauk). Druga grupa 
wydobywała irracjonalne, a zarazem reakcyjne elementy spuścizny ideologicznej konfucjanizmu ${ }^{59}$.

Po okresie rewolucji kulturalnej i po upadku Lin Biao w ramach nowej kampanii krytyki Konfucjusza górę wzięła koncepcja totalnej krytyki Konfucjusza. Dużą rolę w tym zakresie odegrał profesor Jang Jung-kuo - historyk z Uniwersytetu w Kantonie, który w licznych pracach, pisanych na zamówienie władz partyjnych, poddawał ostrej krytyce poglądy Konfucjusza, określając go jako „ideologa zacięcie broniącego ustroju niewolniczego", a także walkę dwóch linii w ideologii okresu wczesnej i późniejszej dynastii Han. Autor przedstawiał Konfucjusza jako ideologa skazanej na upadek klasy właścicieli niewolników, co profesor uznał za reakcyjne. Jednocześnie autor chwalił legistów, czyli jedną ze szkół konfucjanizmu, która tak się rozwinęła, że właściwie stała się zaprzeczeniem pierwotnego konfucjanizmu. Przypomnijmy, że legiści mniej uwagi zwracali na cechy etyczne konfucjanizmu, stali się natomiast apolegetami państwa prawa, scentralizowanego i stawiającego na szczycie piramidy cesarza, a właściwie jego prawo. Pod tym względem legiści wyprzedzili o ponad 2 tys. lat austriackiego konstytucjonalistę Hansa Kelsena, stawiającego na szczycie źródeł prawa konstytucję. Ale to przeciwstawienie miało swój walor użyteczności w czasach Mao Tse-tunga, gdyż było wyrazem krytyki pod adresem poprzedniego ustroju, jak i upadłych frakcji, które „myślały po staremu”. Jednocześnie wykorzystywały one legistów i ich autorytet dla umocnienia nie tylko pozycji Mao Zedonga w partii i państwie, ale w ogóle umocnienia państwa dyktatury ludu chińskiego. Nawiązując do czasów aktualnych można skonstatować, że kwestia ta jest także aktualna i ważna dla kierownictwa Xi Jinpinga, który mocno

59 M.I. Sładkowskij et al. (red.), Najnowsza historia Chin..., op.cit., S. 668 . 
podkreślał na XIX Zjeździe KPCh w 2017 r. zasadę i praktykę "państwa prawa” i „rządów prawa”, stawiające respektowanie prawa, przede wszystkim norm konstytucji, przez wszystkich obywateli, instytucje, w tym KPCh.

Wracając do poprzedniej narracji, po X Zjeździe KPCh w 1973 r. wystąpiła nowa fala krytyki konfucjanizmu w kontekście potępienia Lin Biao. Jednocześnie władze wykorzystały tę krytykę do dalszych napaści na Związek Radziecki i KPZR, oskarżanych o nowy hegemonizm i rewizjonizm. Schyłkowy okres życia Mao Zedonga to jednocześnie osłabienie jego autorytetu politycznego i pozycji w KPCh. Partia przestała być monolitem ideowo-politycznym, na to nakładały się głębokie różnice $\mathrm{w}$ międzynarodowym ruchu komunistycznym, w szczególności między KPZR a KPCh, co pociągało za sobą wielkie osłabienie międzynarodowego ruchu robotniczego i jednocześnie umacniało imperializm.

W Chinach podziały wewnętrzne skupiały się głównie wobec sporów na temat dróg i metod dalszej budowy socjalizmu; chodziło głównie o kwestie rynku, większą tolerancję dla prywatnej inicjatywy i otwarcia się Chin na zewnątrz. Część kierownictwa chińskiego stała na stanowisku, że Chiny przy szczupłości własnych środków i ogromnym przyroście ludności same sobie nie poradzą i muszą wejść na drogę pewnej kooperacji z kapitałem zagranicznym przy zachowaniu priorytetu własnych interesów gospodarczych, finansowych i zagranicznych. Na czele tej grupy stali Deng Xiaoping i Liu Szaotsi, którzy byli konsekwentnie zwalczani, a nawet prześladowani przez Mao Zedonga jako „kroczący drogą kapitalistyczną". Mao był zwolennikiem wczesnych założeń Marksa, wiążących rynek z gospodarką kapitalistyczną, natomiast gospodarka socjalistyczna miała rozwijać się według dyrektyw centralnego planowania. Te zasady wdrożone do praktyki Rosji radzieckiej przez Lenina wykazały słabość w obliczu ogrom- 
nego zacofania gospodarczego Rosji i w konsekwencji wielkich zniszczeń przez rewolucję i wojnę domową. Stąd Lenin dokonał zasadniczej zmiany polityki, wprowadzając Nową Politykę Ekonomiczną (NEP), opartą m.in. na warunkach gospodarki towarowo-pieniężnej i dopuszczając rynek jako sposób wymiany towarowej głównie między miastem a wsią.

Była to poważna korekta nauki Marksa o prawach socjalizmu, a właściwie okresu przejściowego od kapitalizmu do socjalizmu. Rekorektę tej polityki z kolei przeprowadził z ważnych powodów wewnętrznych i zewnętrznych Stalin w końcu lat 20., kierując się większymi efektami ekonomicznymi centralnie sterowanej gospodarki planowej ZSRR i w obliczu rosnącego zagrożenia faszystowskiego. Mao Zedong był wiernym uczniem Stalina i podobnie jak on srogo zwalczał zwolenników osłabienia centralnego planowania i wprowadzenia ograniczonych mechanizmów rynkowych, przy czym gospodarka ta w Chinach nawet przy błędach Wielkiego Skoku i rewolucji kulturalnej odnotowywała średnio rocznie 6\% wzrostu, co jednak było prawie w całości „konsumowane” przez ogromny przyrost naturalny. W tej sytuacji Deng Xiaoping już w 1967 r. sformułował powiedzenie, że „nieważne jest czy kot jest biały, czy czarny, ważne jest, żeby łapał myszy”. Oznaczało to zdaniem Denga, że na obecnym etapie rozwoju Chin nie jest zagrożony socjalizm, a główną sprzeczność wyznaczają nie sprzeczności klasowe i walka klasowa, ale sprzeczność między rosnącymi potrzebami i aspiracjami społeczeństwa a możliwościami ich realizacji przez mało efektywną gospodarkę. Mao Zedong traktował tę wypowiedź jako marksistowską herezję. Choć od 1949 r. upłynęło wiele lat, często podkreślał, że po rewolucji i wprowadzeniu socjalizmu w Chinach klasy nie zniknęły całkowicie. „Nawet po uspołecznieniu własności klasy istnieją nadal" - powtarzał w 1962 r. Stwierdził, że w Chinach „walka klasowa nadal trwa”, „walka klasowa między proletaria- 
tem a burżuazją potrwa długo” i „może przybierać okresowo różne formy" ${ }^{\prime 6}$.

Dalej Mao dawał wyraz trosce o dalszy rozwój Chin, mówiąc, że „Chiny mogą stanąć przed niebezpieczeństwem restauracji kapitalizmu”. Przypomniał, że „burżuazja przenika też do KPCh, podobnie jak wcześniej do innych partii komunistycznych, które przechodzą na drogę kapitalizmu". Odnosiło się to w szczególności do Deng Xiaopinga i Liu Szaotsi, których oskarżał o „idących drogą kapitalistyczną”, nawet swemu najwierniejszemu współpracownikowi Czou Enlajowi w 1974 r. „przypiął łatkę" konfucjanisty ${ }^{61}$.

Ta ostrożność i obawy o przyszłość socjalizmu i zagrożenia kontrrewolucyjne nie były bezzasadne. Potwierdzały je historia ruchu robotniczego, rosnący rewizjonizm, reformizm i oportunizm w ruchu komunistycznym, a przede wszystkim upadek KPZR i ZSRR, także państw demokracji ludowej w Europie w końcu lat 80. XX w. Przełomem w dążeniach do wprowadzenia nowej polityki ekonomicznej, zwanej później „socjalistyczną gospodarką rynkową, była śmierć wieloletniego premiera Chin Czou Enlaja w styczniu 1976 r. i we wrześniu tego roku Mao Zedonga. Już w końcowych miesiącach ich rządów przewagę w kierownictwie partyjno-rządowym zdobyła frakcja Deng Xiaopinga, co potwierdzały odwołania ich przedstawicieli z zesłania na głęboką prowincję („w celach reedukacji”) i przywrócenia do działalności na najwyższych stanowiskach partyjnych i państwowych. Po śmierci Mao Zedonga przez miesiąc trwała ostra walka między obu frakcjami, zakończona upadkiem „bandy czworga", aresztowaniem i osądzeniem jej przywódców (w tym m.in. małżonki Mao p. Jiang Qing) i budowaniem nowego przywództwa w KPCh na czele z Deng Xiaopingiem, co trwało kilka

\footnotetext{
60 Cyt. za: Li Zhisui, Prywatne życie..., op.cit., s. 398.

61 Ibidem, s. 585.
} 
lat, zanim wdrożony został program nowej polityki. W tym czasie po burzliwych latach rewolucji kulturalnej i walk frakcyjnych opanowano chaos w gospodarce, uporządkowane sprawy jednolitego kierowania państwem, a w szczególności przywrócono jedność ideowo-polityczną w szeregach partii na zasadach zaufania między członkami partii a kierownictwem i respektowania zasady realizacji linii mas. Jednocześnie po szerokiej i głębokiej dyskusji wewnętrznepartyjnej dokonano oceny miejsca i roli Mao Zedonga w historii KPCh i ChRL, uznając zasadę, że był on wybitnym przywódcą Chin i jego zasługi w walce o wyzwolenie chińskiego ludu spod ucisku kapitalistycznego i zwycięstwa rewolucji demokratycznej i socjalistycznej są historyczne i nie mogą być pominięte. Co prawda Mao w schyłkowym okresie popełnił wielkie błędy, ale były to błędy wielkiego rewolucjonisty, które stanowiły nie więcej niż 30\% w sytuacji, gdy zasługi stanowiły $70 \%$ jego życia. Było to wyrazem wielkiego uznania dla dotychczasowego przywódcy, jednocześnie prawidłowego wyważenia relacji między pozytywami i negatywami jego działalności politycznej. Jednocześnie realizację nowej polityki ekonomicznej uznano nie jako negację poprzedniego kierownictwa, ale jako jej kontynuację w nowych warunkach wewnętrznych i międzynarodowych ${ }^{62}$.

Deng Xiaoping wielokrotnie podkreślał, że społeczeństwo socjalistyczne, a tym bardziej komunistyczne nie może być oparte na nędzarskiej ekonomice, zaspokajającej tylko podstawowe potrzeby życiowe swych obywateli. W tej sytuacji wzrasta znaczenie okresu przejściowego od kapitalizmu do socjalizmu jako samodzielnego i względnie długotrwałego etapu. Chiny muszą uczynić wszystko, by przyspieszyć rozwój gospodarczy i poziom społeczny świata pracy. Jednocześnie mimo

62 Deng Xiaoping, Przestrzegać czterech podstawowych zasad, [w:] idem, Chińska droga do socjalizmu, Warszawa 1988, s. 114 i n. 
osiągniętych sukcesów socjalistycznej rewolucji i trzydziestu lat budownictwa socjalistycznego należy skuteczniej rozstawać się z pozostałościami feudalizmu i mentalności klanowej, w czym dużą rolę odgrywały pozostałości konfucjanizmu. Do najważniejszych przywódca zaliczył: 1. Utrzymywanie się nadal w społeczeństwie mentalności klanowej; 2. W stosunkach społecznych nadal utrzymywał się stary hierarchiczny porządek; 3. Występowały także określone przejawy nierówności statusu w kontaktach między towarzyszami ze szczebla kierowniczego a ich podwładnymi oraz w stosunkach między kadrą a masami; 4. Słabe zrozumienie w społeczeństwie praw i obowiązków obywatelskich; 5. W sferze gospodarczej nadal panował system i styl mandaryński wśród kadry w przemyśle, handlu, rolnictwie; 6.Nadmierne podkreślanie w pracy ekonomicznej kompetencji regionalnych i resortowych, co prowadziło do partykularyzmu i przerzucania swych kłopotów na innych; 7. Nieuznawanie doniosłego znaczenia nauki i oświaty dla socjalizmu i że bez nauki i oświaty nie można zbudować socjalizmu; 8. Polityka izolacjonizmu i szowinistycznej arogancji w stosunkach z zagranicą; 9. Odrażająca praktyka protekcji [i dodajmy korupcji, przyp. Z.W.]; 10. Naużywanie władzy przez część kadry i preferowanie „swojaków”; 11. Niedocenianie wpływów pozostałości feudalizmu w ideologii i polityce; 12. Trzeba usuwać te piętna i objawy feudalizmu i kapitalizmu, ale tego nie można sprowadzać do jednej akcji, 13. System prawny jest dobry, należy go właściwie stosować: 13 . Nie trzeba ulegać anarchizmowi i indywidualizmowi; 14 . Nie płaszczyć się przed cudzoziemcami, mamy wielkie osiągnięcia; 15. Część młodzieży notabli wyjeżdżając za granicę na studia uprawia łapownictwo i przemyt, zapomina o narodowej dumie i godności osobistej; 16. Do kraju w związku z szerszymi kontaktami przemyca się pornografię, wulgarne filmy i zdjęcia, publikacje, szkodzi to naszej moralności; 17 . Na granicy sektora socjali- 
stycznego i prywatnego pojawiły się różne nielegalne formy aktywności gospodarczej, finansowej ${ }^{63}$.

Deng Xiaoping i jego towarzysze wychodzili z założenia, że podejmowane reformy nie mają na celu odejście od socjalizmu, lecz obronę interesów i utrzymanie władzy ludzi pracy, a więc ogromnej większości społeczeństwa. KPCh nie przekształciła się w partię uprzywilejowanej biurokracji, będącej w klasowym konflikcie z masami ludowymi. Jako cel społeczny partia stawiała poprawę warunków życiowych ludzi pracy. Inaczej niż KPZR na czele z N. Chruszczowem KPCh nie odżegnała się od poprzedniego przywódcy i niezależnie od popełnionych przez niego błędów kontynuowała dzieło rozwoju socjalizmu w nowych warunkach. Wreszcie okres niedawnych walk frakcyjnych, a w szczególności rewolucja kulturalna uświadomiła masom ludowym wagę socjalistycznej rewolucji i dalszej budowy socjalizmu jako gwarancji dalszej poprawy ich bytu i zachowania i umocnienia suwerenności Chińskiej Republiki Ludowej w obliczu pojawiających się zagrożeń imperialistycznych ${ }^{64}$.

Koncepcja socjalistycznej gospodarki rynkowej stała się przedmiotem krytyki nie tylko ze strony chińskich przeciwników i konkurentów politycznych Deng Xiaopinga. Była i w znacznej części jest krytycznie przyjmowana przez zagraniczne partie komunistyczne, generalnie stojących na pozycjach ideologicznych dawnej KPZR i na praktyce ustrojowej dawnego Związku Radzieckiego, opartej na zasadzie centralnego planowania w gospodarce i negacji rynku. W argumentacji sięgano do wypowiedzi Marksa i Engelsa z połowy XIX stulecia, w szczególności wczesnych prac, np. Przyczynku do krytyki ekonomii politycznej czy Manifestu komunistycznego, w których klasycy

63 Idem, Przemówienie wygłoszone na rozszerzonym posiedzeniu Biura Politycznego KC KPCh 18 sierpnia 1980 r., [w:] idem, Chińska droga do socjalizmu..., op.cit., s. 251.

64 M. Rakowski, Przemiany i szanse socjalizmu..., op.cit., s. 122 i n. 
dali wyraz tym zasadom, upatrując je jako fundamentalne dla przyszłej ekonomii socjalistycznej i będących w opozycji do liberalnego mechanizmu gospodarowania XIX-wiecznego kapitalizmu, głównie Anglii, skąd czerpano wzory do modelu stosunków kapitalistycznych.

Problem polegał jednak na tym, że od tego czasu upłynęło ponad 170 lat i świat, w tym kapitalistyczny, bardzo się zmienił. Kapitalizm przeszedł fazę liberalizmu, wkroczył w fazę imperializmu, monopolizacji i ekspansji kolonialnej, będących przedmiotem analizy Lenina, szybkiego rozwoju ruchu robotniczego, a jednocześnie wielkich sprzeczności klasowych, w wyniku których wybuchły II wojny światowe, powstał i rozwinął się faszyzm, nacjonalizm, militaryzm i wiele innych zagrożeń niebezpiecznych dla dalszego istnienia oraz rozwoju ludzkości. Jednocześnie w listopadzie 1917 r. wybuchła w Rosji rewolucja październikowa, która zapoczątkowała nową erę w dziejach ludzkości, mianowicie powstanie Rosji radzieckiej, później ZSRR i innych państw socjalistycznych, republik robotników, chłopów i innych ludzi pracy, państw dyktatury proletariatu, co potwierdzone zostało po II wojnie światowej przez powstanie państw demokracji ludowych w Europie, a w latach 1948-1949 w Korei i Chinach, a następnie w zjednoczonym socjalistycznym Wietnamie. W 1958 r. rewolucja zwyciężyła na Kubie na kontynencie amerykańskim.

Świat wkroczył w epokę rewolucji narodowo-kolonialnych, demokratycznych, niektóre z nich rozwijały się w powstawanie państw podążających drogą niekapitalistycznego rozwoju. W tej sytuacji w międzynarodowym ruchu komunistycznym prowadzona była ożywiona dyskusja nad różnymi drogami rewolucji socjalistycznych i budowy socjalizmu. Podstawowym problem było pytanie czy w tych państwach $\mathrm{z}$ historycznie opóźnionymi strukturami społeczno-gospodarczymi jest możliwa rewolucja socjalistyczna, a w następnym etapie budowa 
podstaw ustroju socjalistycznego. Były to państwa postkolonialne, które w latach 50. i 60. wybiły się na niepodległość, silnie powiązane z dawnymi metropoliami, z których w wielu powstały grupy marksistowskie, organizujące uciśnione ludy do walki z imperializmem i neokolonializmem. Było ich około trzydziestu w Afryce, Azji i Ameryce Łacińskiej. Wzorem dla nich były republiki azjatyckie ZSRR, Mongolia, KRLD. Wietnam, Chińska Republika Ludowa, a w Ameryce Kuba. Były to państwa o zdecydowanej przewadze rolnictwa, o słabo rozwiniętej bazie przemysłowej, najczęściej wydobycia surowców i najczęściej o dużej masie ludności, żyjącej w warunkach lub na granicy nędzy. $Z$ tego powodu od dawna toczyła się tam walka narodowowyzwoleńcza o charakterze partyzanckim, której przywódcy poszukiwali rozwiązań ustrojowych i pomocy w państwach socjalistycznych.

Marks i Engels przewidywali, że socjalizm zwycięży w państwach najbardziej rozwiniętego kapitalizmu, ale w drugie poł. XX w. kapitalizm stał się globalny i skutecznie integrował gospodarczo, politycznie i kulturowo-medialnie narody postkolonialne. W dalszym ciągu wielka była ekspansja kapitału finansowego i przemysłowego na tereny dawnych kolonii, co je włączało w system gospodarczy i polityczny metropolii. Rewolucja demokratyczna w tych państwach była możliwa dzięki postępowym partiom i ruchom, które wywalczyły niepodległość. Mogły one przejść do etapu rewolucji socjalistycznej dzięki poparciu i pomocy Związku Radzieckiego, ludowych Chin, a także innych państw socjalistycznych i w ten sposób zerwać istniejącą jeszcze zależność z dawnymi metropoliami i przyspieszyć budowę nowoczesnej infrastruktury gospodarczej, głównie przemysłowej. Koncepcja ta załamała się po upadku Związku Radzieckiego i państw socjalistycznych w Europie, ale aktualnie ponownie odżywa w następstwie wdrożenia przez Chińską Republikę Ludową tzw. Nowych 
Jedwabnych Szlaków, na który przeznacza ok. 8 bln dolarów w postaci głównie nowych inwestycji bezpośrednich w prawie 150 krajach trzech kontynentów. Można więc skonstatować, że walka klasowa w samych Chinach została od 1978 r. wyciszona, ale nie dotyczyło to relacji międzynarodowych. Socjalizm jest nadal ustrojem atrakcyjnym dla państw rozwijających się i tym razem czerpią one wiedzę o nim oraz próbują wdrażać pewne modele gospodarczo-społeczne w oparciu o praktykę ustrojową ChRL.

Po czterdziestu latach realizacji „socjalistycznej gospodarki rynkowej" Chiny stały się druga potęgą gospodarczą świata, jej PKB w 2018 r. liczył ponad 20 bln dol., licząc wg kursu siły nabywczej juana, należą do Rady Bezpieczeństwa ONZ jako jej stały członek i żaden problem światowy nie może skutecznie być rozwiązany bez udziału ChRL Ale przed czterdziestu laty kierownictwo Chin stanęło przed trudnym zadaniem, jak nie dać się zmiażdżyć przez silnego nie tylko ekonomicznie, także militarnie wroga, głównie imperializm amerykański, jakie środki zastosować, by nie dać się pokonać, jak obronić socjalizm, niepodległość i władzę ludową oraz wprowadzić w błąd klasowego wroga, a jednocześnie stworzyć taki typ relacji międzynarodowych, głównie ekonomicznych i handlowych, które pozwolą na szerokie stosunki z przodującymi rozwiniętymi gospodarczo państwami kapitalistycznymi i uratować nie tylko Chiny jako naród, ale także socjalizm jako wartość międzynarodowa..

Chińczycy od dawna stosują w poznaniu świata zasadę poznania prawdy w oparciu o fakty. Pozwala to realistycznie analizować sytuację i wyciągać wnioski z praktyki społecznej. Nie jest to zwykły empiryzm, metoda ta powiązana jest $\mathrm{w}$ dalszym procesie poznawczym $\mathrm{z}$ analizą i przetwarzaniem danych w oparciu o zasadę materializmu historycznego i dialektycznego, a więc różnicy interesów klasowych między pro- 
letariatem a burżuazją, kapitalizmem i imperializmem a socjalizmem i komunizmem. Pomocne tu było doświadczenie Rosji radzieckiej i okresu NEP-u na początku lat 20. XX w., kiedy ZSRR odstąpił od komunizmu wojennego gospodarki radzieckiej i poszedł na dalekie odstępstwa od „czystych” zasad budownictwa komunistycznego, sformułowanych przez dotychczasową teorię naukowego socjalizmu. Żeby zrobić dalszy krok naprzód, trzeba czasem cofnąć się nie o jeden krok. Tak uczył Lenin zasad dialektyki, narażając się na krytykę nie tylko ze strony teoretyków-marksistów, ale nawet na zarzut zdrady interesów rosyjskiego i międzynarodowego ruchu robotniczego. Okres NEP-u nie był tylko związany z Leninem. Po jego śmierci w styczniu 1925 r. NEP był kontynuowany przez nowe kierownictwo WKP(b) na czele z J. Stalinem i trwał do końca 1928 r., a następnie został zastąpiony przez gospodarkę centralnie planową, którą zapoczątkował pierwszy plan 5-letni, jak również kolektywizacja rolnictwa.

Jednakże o wyborze socjalistycznej gospodarki rynkowej, jak później nazwano eksperyment chiński, zadecydowały nie tylko względy historyczno-teoretyczne. Chińczycy dysponowali własnym doświadczeniem i wielkimi atutami, które stanowiły dostateczną gwarancję, że nowy model gospodarowania ma szanse pozyskania poparcia ze strony klasy robotniczej, chłopstwa i innych ludzi pracy, przyczyni się do ożywienia własnej gospodarki, a jednocześnie wprowadzi zamieszanie i dezorientację w ośrodkach burżuazyjno-imperialistycznych. Zaczynając od tego ostatniego rząd USA jak i wielkie ośrodki opiniotwórcze z uznaniem odniosły się do nowej polityki chińskiej, upatrując w niej mechanizm, który postrzegany był jako podążanie przez Chińczyków śladami upadającego ZSRR, co w literaturze naukowej przedstawione zostało przez F. Fukuyamę jako „koniec historii", a więc ostateczne zwycięstwo kapitalizmu w formie USA, a co Z. Brzeziński określił jako nowy światowy porządek 
"new world order" (za prezydentem Bushem), który jednocześnie określił socjalizm jako „błąd historii”, który nie miał prawa się pojawić, ale niestety wystąpił i obecnie świat ponownie wszedł w prawidłowe i sprawdzone koleiny. Z tych powodów amerykańscy i światowi kapitaliści z wielkim zaangażowaniem przystąpili do masowej ekspansji kapitałowej w Chinach, poczytując je jako obszar neokolonialnej penetracji, licząc na olbrzymie zyski. Gwarantowały to olbrzymi rynek, miliardowa ludność, tania siła robocza i wielkie bogactwa naturalne kraju. Chiny wydawały się nadzwyczaj łatwą zdobyczą. Nadzieje te spełniły się tylko częściowo, inwestycje bezpośrednie rzeczywiście przynosiły krociowe zyski, ale ChRL nie zrezygnowała ze swych ze swych suwerennych praw i dzięki silnemu rządowi, pilnie strzegącemu interesów narodowych i odpowiednim kontraktom, musiały one respektować prawo inwestycyjne, finansowo-bankowe, zasad kodeksu pracy, a także inne gałęzie prawa chińskiego. W ten sposób Chiny nie stały się nową kolonią ani nie uległy mechanizmom wyzysku neokolonialnego. Utrzymały także jedność kraju i nie dały się rozczłonkować, co było realne w epoce przedrewolucyjnej ${ }^{65}$.

Jednocześnie Chiny uruchomiły własny narodowy kapitalizm, ściśle kooperujący z sektorem socjalistycznym, wchodząc także w relacje $\mathrm{z}$ korporacjami zagranicznymi, ucząc się od nich, przechwytując i naśladując najnowsze rozwiązania technologiczne i produkcyjne. W konsekwencji tej polityki Chiny stały się wielkim placem budowy, powstało tysiące nowych przedsiębiorstw tak produkcyjnych, jak i handlowych i usługowych, co roku przybywało średnio $10 \mathrm{mln}$ nowych miejsc pracy w najnowocześniejszych gałęziach gospodarczych, a drugie tyle było modernizowanych. Wielkim atutem socjalistycznej

65 Szerzej na ten temat zob. Z. Wiktor, M. Rakowski, Rozwój i prognozy przyszłości Chin w zmieniającym się świecie, Toruń 2012, s. 66 i n. Zob. też: M. Rakowski, Przemiany i szanse socjalizmu..., op.cit., s. 124 i n. 
gospodarki rynkowej była niezwykle tania i konkurencyjna siła robocza, której praca i wysiłek przynosiły olbrzymie zyski inwestorom. Te inwestycje i praca chińskich robotników modernizowała i rozwijała chińską gospodarkę, podnosiła produkcję i wdrażała nowe technologie. Reformy ożywiły także rynek, który przestał być traktowany jako mechanizm charakterystyczny dla gospodarki kapitalistycznej. Deng i jego grupa dokonali zasadniczego zwrotu w stosunku do rynku, uznając, że może on być pożyteczny w warunkach Chin, które znajdują się dopiero na „wstępnym, początkowym etapie budownictwa socjalistycznego", gdzie występuje mnogość sektorów gospodarowania, dla których powinny istnieć możliwości rynkowej konkurencji, przy zachowaniu jednak kierowniczej roli partii komunistycznej i sterującej roli państwa. Uznali oni, że rynek na tym etapie nie musi szkodzić sektorowi socjalistycznemu, a nawet może być instrumentem zwiększenia jego efektywności. Chińczycy zmienili też charakter planowania, które w dotychczasowej praktyce (powielanej za wzorem radzieckim) miała charakter scentralizowany i indykatywny, przekształcając je w sterujące, zawierające wskaźniki i dyrektywy odnoszące się do gałęzi gospodarczych, makropolityki i polityki monetarnej w skali kraju. Zmiany te przyczyniły się do ożywienia konkurencji między przedsiębiorstwami, nastąpił wzrost produkcji, także rolnej, co przyczyniło się do zrównoważenia popytu i podaży artykułów żywnościowych na rynku.

Chińczycy nie odeszli od głównego celu, jakim jest budowa socjalizmu, zmienili jednak sposoby dochodzenia do niego. W przeciwieństwie do byłych państw socjalistycznych - ZSRR i KDL-ów w Europie, gdzie zasada „niewidzialnej ręki rynku” została podniesiona jako główna reguła rynku kapitalistycznego, rozszerzyli ją o drugą zasadę, mianowicie „widzialnej ręki rządu", umożliwiającej ingerencję państwa, jeśli zagrożone były interesy Chin, co stworzyło podstawę nowej strategii gospo- 
darczej, nazwanej kilka lat później jako „socjalistyczna gospodarka rynkowa”. W opinii Deng Xiaopinga zmiany w polityce gospodarczej Chin otworzyły olbrzymie możliwości napływu obcych kapitałów, które modernizowały kraj, rozwijały go technologicznie, stwarzały perspektywy budowy setek milionów miejsc pracy, a tym samym rozwiązywania palących problemów narodu chińskiego. Jednocześnie reformy stworzyły nowy typ relacji między kapitalizmem a socjalizmem, opartych na zasadach kooperacji i pokojowego współistnienia, które po czterdziestu latach przyniosły wielkie sukcesy nie tylko gospodarcze, także w sferze polityki socjalnej, np. stworzenie i modernizowanie setek milionów miejsc pracy, rozwinęły się nowe centra i regiony gospodarcze Chin, zmodernizowano i wybudowano nowe układy komunikacyjne, ulokowano wielkie inwestycje w regionach dotychczas historycznie zaniedbanych, wprowadzono z nędzy ok. $700 \mathrm{mln}$ ludzi, co jest ewenementem w skali światowej. Oczywiście powstały także nowe zagrożenia i bariery, których władze ChRL nie ukrywają, ale im przeciwdziałają i je rozwiązują zgodnie z interesami narodu chińskiego ${ }^{66}$.

\section{Charakter reform polityczno-ekonomicznych w epoce Deng Xiaopinga}

Często można spotkać się z poglądem, że reformy zapoczątkowane przez Deng Xiaopinga i jego zwolenników były podyktowane odejściem od marksizmu-leninizmu i socjalizmu i „pokojowym" przechodzeniem do kapitalizmu. Takie były nadzieje polityków państw kapitalistycznych, szczególnie o nastawieniu imperialistycznym i sekundujących im uczonym burżuazyjnym.

66 Różne aspekty tych zagadnień podejmują autorzy książki pt. Wektory zmian w polityce Chińskiej Republiki Ludowej w okresie rząów Xi Jinpinga, red. J. Marszałek-Kawa, M. Bidziński, Toruń 2018, s. 9 i n. 
Reformy te ze sceptycyzmem, a nawet krytyką były i są przyjmowane przez zwolenników tradycyjnego („ortodoksyjnego”) marksizmu, szczególnie w Europie Zachodniej. Deng Xiaoping dostrzegał nową wielką sprzeczność między warunkami ekonomiczno-socjalnymi państw słabo rozwiniętych i wysoko rozwiniętych, z których te pierwsze dążyły do socjalistycznej rewolucji. Rozwijając marksizm w nowej współczesnej epoce doszedł on do przekonania (idąc za Mao Zedongiem), że w państwach postkolonialnych, ciągnących za sobą balast historycznego zacofania i neokolonialnej zależności od metropolii kapitalistycznych, rewolucja socjalistyczna musi mieć kilka etapów, musi być narodowowyzwoleńcza, antykapitalistyczna, także częściowo antyfeudalna, demokratyczna, a dopiero w następnych latach przejść do etapu rewolucji socjalistycznej. Myślenie to było więc kontynuacją ustaleń teoretycznych Lenina co do możliwości rewolucji socjalistycznej w Rosji, a także u narodów Wschodu. Koncepcja ta znalazła także rozwinięcie w długotrwałej walce ludu chińskiego o wyzwolenie narodowe, społeczne, o rewolucję demokratyczną i socjalistyczną, która ostatecznie zakończyła się zwycięstwem w październiku 1949 r. proklamowaniem Chińskiej Republiki Ludowej.

W przeciwieństwie więc do wysoko rozwiniętych państw kapitalistycznych, gdzie istnieje szeroka baza przemysłowa i silna klasa robotnicza, w państwach nierozwiniętych istnieją dopiero początki tych sektorów przy wielkiej dominacji tradycyjnych i konserwatywnych sektorów, spętanych świadomością polityczną, religijną i ideologiczną klas reakcyjnych. We współczesnej epoce kapitalizm ma charakter globalny i rewolucja może wybuchnąć w jego każdym zakątku, ale możliwości jej trwałego zwycięstwa w państwach słabo rozwiniętych są ograniczone i wymagają znacznie większego czasu dla osiągnięcia skomplikowanych celów procesu rewolucyjnego. Dobitnym przykładem tego są dzieje rewolucji w Rosji i ZSRR, w Chinach, 
Wietnamie, Kubie i w innych rejonach świata, np. rewolucja narodowo-demokratyczna w Chile, Nepalu, Wenezueli, Nikaragui. Podstawowym problemem takich państw po zdobyciu władzy jest kwestia okresu przejściowego od kapitalizmu do socjalizmu, który w takich państwach może trwać dziesiątki, a nawet setkę lat i w gruncie rzeczy staje się długotrwałym samodzielnym okresem przemian rewolucyjnych, w którym występują różne sektory własnościowe (nie zawsze powiązane z wielką własnością kapitału międzynarodowego) i towarzyszące im sprzeczności ekonomiczne, socjalne i polityczne, które muszą bardzo umiejętnie być rozwiązywane przez partie komunistyczne. Kapitalizm we współczesnej epoce, a szczególnie imperializm znajduje się w schyłkowej fazie rozwoju. USA i inne mocarstwa imperialistyczne przeszły apogeum swego rozwoju, szczególnie w gospodarce, weszły w stan permanentnego kryzysu wewnętrznego i w stosunkach międzynarodowych, ale dysponują przewagą militarną, którą szantażują uciśnione narody i wewnętrzne siły postępu społecznego. Tu tkwi ta głęboka sprzeczność i problem jak je rozwiązać bez niszczycielskiej wojny, która w obecnej epoce może graniczyć z zagładą całej ludzkości.

W związku z tym przed Deng Xiaopingiem pojawiło się kilka wielkich problemów o naturze historycznej i dotyczących przyszłości. Chodziło głównie o stosunek do Mao Zedonga, który w schyłkowym okresie popełnił liczne błędy polityczne i ekonomiczne (o czym wyżej już wspomniano) i które skutkowały wielkimi stratami ludzkimi i ekonomicznymi. Jednocześnie miał on wielkie zasługi jako rewolucjonista, który od ponad pół wieku organizował i kierował ruchem komunistycznym w Chinach, prowadził walkę zbrojną z wrogami wewnętrznymi i zagranicznymi oraz doprowadził rewolucję do zwycięskiego końca. Miał wielkie zasługi w dziele budowy podstaw ustroju socjalistycznego, ale w schyłkowym etapie życia poczynił liczne 
błędy, które jednak nie przekreślały jego działalności. W trakcie dyskusji wewnątrzpartyjnej uznano, że zasługi Mao to 70\%, a błędy 30\%, zatem całość jego działalności i życia jako rewolucjonisty są pozytywne. Nowe kierownictwo nie odrzuciło dorobku i nauk Mao Zedonga, jego teoria budowy socjalizmu w Chinach stała się pomostem do nowego etapu tego budownictwa. Sam Deng Xiaoping, mimo wcześniejszych prześladowań ze strony Mao Zedonga, podkreślał, że był on wielkim marksistą i sam czuje się kontynuatorem dzieła wielkiego przywódcy i rewolucjonisty. KPCh uznała, że idee Mao, które realizował przez większą część życia, a głównie „linia mas”, a więc dbałości o interesy ludzi pracy i obustronny związek oraz porozumienie między masami i kierownictwem partii na wszystkich szczeblach, jak również opierania się w polityce na chińskich realiach wzbogacało teorię marksizmu-leninizmu w Chinach, w związku z czym KPCh będzie kontynuować realizację tych idei pod sztandarem „Myśli Mao Zedonga” ${ }^{67}$.

Istotą zamian, które nastąpiły w Chinach po śmierci Mao Zedonga było wprowadzenie rynku do mechanizmu gospodarczego, czyli, jak później określano, nowego modelu budowy socjalizmu (a nie w ogóle socjalizmu), czyli „socjalizmu rynkowego" lub „socjalistycznej gospodarki rynkowej”, którą to zasadę wpisano do Konstytucji ChRL z 1982 r. w ramach drugiej poprawki do Konstytucji z $1993 \mathrm{r} .{ }^{68}$ Deng Xiaoping stale podkreślał, że fakty są podstawą jego myślenia i polityki. Sięgał więc w tym względzie do tradycji nie tylko marksistowskiej, także konfucjańskiej, która postrzegała nie tylko fakty, także realia jako podstawę postrzegania życia i jego oceny. Właśnie te realia chińskie stały się podstawą oceny budowy socjalizmu i jego przyszłości w Chinach. Deng Xiaoping mówił głośno

67 Z. Wiktor, Chiny na drodze socjalistycznej modernizacji..., op.cit., s. 272.

68 Ibidem, s. 183, 247. 
to, co wszyscy widzieli. Chiny są wielkim narodem, silnym państwem, spajane więzami liczącej kilka tysięcy lat cywilizacją, ale w XX w. były ogromnie zacofane, przede wszystkim w stosunku do świata zachodniego, państw imperialistycznych i piętrzyły się przed nimi olbrzymie trudności, których przezwyciężenie wymagało głębokich reform i odwagi w myśleniu. Krótko mówiąc, teoria Deng Xiaopinga zakładała, że, jak to celnie ujął prof. Mieczysław Rakowski:

1. Jest to w istocie realizacja tego samego celu, a więc obrony interesów i utrzymania władzy ludzi pracy, a więc ogromnej większości społeczeństwa, ale innymi metodami, odpowiadającymi realiom zewnętrznym i wewnętrznym, w których znajdowała się po śmierci Mao, a także znajduje się obecnie Chińska Republika Ludowa. Wyciągając wnioski z upadających KPZR i ZSRR KPCh nie zmieniła się w partię uprzywilejowanej biurokracji, zantagonizowaną w stosunku do ludowych mas.

2. Nowe kierownictwo zdawało sobie sprawę z tego jak niesłychanie negatywny wpływ polityczny na społeczeństwo wywiera oczernianie zmarłego przywódcy (Stalina) przez tych samych ludzi z nowego kierownictwa KPZR, którzy jeszcze niedawno go wysławiali.

3. Na ogół rewolucja kulturalna w Chinach jest traktowana jako okres chaosu, ale miała ona ważny plus, gdyż, jak pisze Rakowski, „rozkołysała ona masy, co mimo elementów anarchizmu politycznego i wywołanego chaosu gospodarczego, wzmocniło w nich poczucie należnych im praw ekonomicznych, socjalnych i politycznych, tj. tego, że to one są gospodarzem kraju i że polityka partii, aby być przez nie akceptowana, musi uwzględniać przede wszystkim ich interesy i być z nimi uzgadniana" ${ }^{69}$. W kon-

69 M. Rakowski, Przemiany i szanse socjalizmu..., op.cit., s. 123. 
sekwencji nowy etap budowy socjalizmu w Chinach od 1978 r. dbywał się według czterech zasad ideologii i polityki KPCh: 1. trzymania się socjalistycznej drogi; 2. przestrzegania dyktatury proletariatu (ludu); 3. przestrzegania kierowniczej roli Komunistycznej Partii Chin; 4. przestrzegania marksizmu-leninizmu i myśli Mao Zedonga ${ }^{70}$.

Trzymając się realiów Deng uznał, że Chiny jako wielki i ekonomicznie zacofany kraj nie może iść niesocjalistyczną drogą rozwoju, jak np. małe państwa azjatyckie tzw. „tygrysy azjatyckie”, które stały się „dodatkami” do USA i innych państw kapitalistycznych. Ich losy dowodziły, że Chiny utraciłyby niepodległość i stałyby się celem neokolonialnej ekspansji mocarstw imperialistycznych, a więc Chiny muszą się rozwijać w oparciu o własne siły, a współpraca z państwami kapitalistycznymi może być tylko uzupełnieniem. Dlatego zezwolono także na wzrost inicjatywy prywatnej w gospodarce przy zachowaniu własności ziemi w rękach państwa i wiodących gałęzi przemysłowych, co pozwoliło na zabezpieczenie podstawowych potrzeb całego narodu bez ogromnego rozwarstwienia i pasożytniczego spożycia burżuazji ${ }^{71}$.

Realizacja tego celu uruchomiła dużą energię w gospodarce i w ciągu ponad czterdziestu lat socjalistycznej gospodarki rynkowej przyniosła zwielokrotnienie dochodu narodowego i poprawę warunków życiowych dla setek milionów ludzi, zmieniła oblicze socjalno-ekonomiczne kraju. Obecnie Chiny są państwem, w którym wg oficjalnych danych poziom PKB na 1 mieszkańca w 2018 r. wynosił około 10 tys. dol. USA (dane pobrane z Internetu), a uwzględniając siłę nabywczą

70 Ibidem.

71 Ibidem, s. 123-124, zob. też: Z. Wiktor, Chiny na drodze socjalistycznej modernizacji..., op.cit., s. 272; Deng Xiaoping, Przestrzegać czterech podstawowych zasad, [w:] idem, Chińska droga do socjalizmu. Wybór pism 1956-1987, Warszawa 1988, s. 99, a w szczególności s. 106 i n. 
juana prawie $50 \%$ więcej. W skali globalnej wynosi to ponad 20 bln dol., co sytuuje Chiny w pierwszej trójce świata: USA, Chiny, Unia Europejska. Chiny stały się potęgą przemysłową i handlową, rozwinęły nowoczesne rodzaje usług, produkcja zbóż sięga ok. $630 \mathrm{mln}$ ton rocznie, w zasadzie rozwiązano problem wyżywienia narodu, olbrzymie jest budownictwo mieszkalne, kraj jest nieustannie modernizowany pod względem komunikacyjnym, rozwoju nowoczesnej infrastruktury, bezpieczeństwa i porządku strzeże silna armia i policja. Chińska Republika Ludowa jest demokratyczną dyktaturą ludu, w której kierowniczą rolę pełni Komunistyczna Partia Chin. Nie oznacza to, że w Chinach nie ma sprzeczności, które mogą jej zagrażać. Na XIX Zjeździe KPCh w 2017 r. jako główne zagrożenie widziano w rosnącej korupcji, której wypowiedziano zdecydowaną walkę, a także pogłębiające się rozwarstwienie socjalno-ekonomiczne ${ }^{72}$.

Realizacja socjalistycznej gospodarki rynkowej wymagała spełnienia wymienionych warunków politycznych. Trzeba utrzymać dyktaturę proletariatu, formułowaną jako dyktaturę ludu pracującego nad elementami burżuazyjnymi i warstwami ciążącymi do niej, starającymi się żyć z różnych form wyzysku i spekulacji. Dlatego w dalszym ciągu należy pamiętać, że walka klasowa w Chinach nadal trwa i może się ona czasowo nasilać, ale nie ma ona znaczenia wiodącej sprzeczności, głównie w dalszym ciągu między niskim poziomem rozwoju gospodarczego a rosnącymi potrzebami narodu. Dyktatura ludu oznacza demokrację dla ludu, co oznacza, że partia państwo i cały system polityczny zorientowane są na stałe wsłuchiwanie się w dążenia mas i formułowanie w polityce „linii mas”, które

72 Więcej na ten temat zob. Z. Wiktor, Chińska wizja budowy socjalizmu w świetle materiałów XIX Zjazdu KPCh, [w:] Wektory zmian w polityce Chińskiej Republiki Ludowej w okresie rządów Xi Jinpinga, red. J. Marszałek-Kawa, Toruń 2018, s. 27 i n. 
zaspokajają interesy ludu. Musi być ścisłe zaufanie między partią a masami, nieustanne mówienie prawdy i stałe konsultacje na wszystkich szczeblach systemu politycznego.

Utrzymanie socjalizmu i demokratycznej dyktatury proletariatu (ludu) wymaga utrzymania kierowniczej roli partii komunistycznej, ale nie tylko z powodu historycznych zasług, ale dlatego, że stanowi ona zaporę przeciwko burżuazji, która się na nowo odrodziła wewnątrz kraju, ale także przeciwko burżuazji międzynarodowej i zagranicznej, które przez politykę USA $\mathrm{i}$ innych państw imperialistycznych stanowią realne zagrożenie dla socjalizmu i niepodległości Chin. Doświadczenia ZSRR, a także innych b. państw socjalistycznych w Europie, szczególnie w Polsce, dowodziły, że rządzące tam partie komunistyczne i robotnicze, a tym samym znaczna część klasy robotniczej pozostawała pod silnym wpływem odrodzonej burżuazji wewnętrznej i uległa silnym wpływom ośrodków burżuazyjnych państw kapitalistycznych, co przyczyniło się do obalenia socjalizmu w tych państwach pod koniec XX w.

W związku z tym ustrój państwa, a przede wszystkim KPCh musi w dalszym ciągu opierać się na zasadzie centralizmu demokratycznego i ze zwiększoną siłą muszą być odpierane rodzące się niebezpieczeństwa, a nawet zwyrodnienia biurokratyczne, które miały miejsce w b. ZSRR i państwach demokracji ludowej, a także częściowo w ChRL. Jako kolejny warunek tej nowej polityki Deng Xiaopinga było utrzymanie marksistowsko-leninowskiej teorii materializmu historycznego oraz dialektycznego i tej praktyki politycznej, jak również gospodarczej, która zdała egzamin, tych idei, które Mao Zedong głosił i realizował przez wiele dziesiątków lat chińskiej rewolucji.

Ta skrótowa analiza reform Deng Xiaopinga i ich praktyki przez pierwszych dwadzieścia lat (do końca życia Denga) przyniosła olbrzymie sukcesy gospodarcze i socjalne dla Chin, wielkość dochodu narodowego w przeliczeniu na porównywal- 
ną siłę nabywczą juana osiągnęła $51 \%$ dochodu USA ${ }^{73}$.

W następnych prawie dwudziestu latach w 2018 r., o czym już wspomniano dochód ten osiągnął mniej więcej poziom USA, stawiając ekonomikę Chin jako porównywalną pod względem wysokości poziomu PKB w tym kraju, ale oczywiście przy zasadniczo odmiennej jego strukturze i celach społecznych. Jednocześnie trzeba wskazać, że jest on 4-4,5 razy mniejszy, jeśli liczymy go per capita, co wynika z różnicy ilościowej ludności obu państw.

Analiza osiągnięć socjalistycznej gospodarki rynkowej w ciągu ostatnich ponad czterdziestu lat nie może także pomijać innych słabości chińskiej gospodarki, przede wszystkim znacznie niższej wydajności pracy niż w przodujących państwach Ameryki Północnej i Europy Zachodniej. Ten osiągnięty wysoki globalnie poziom produkcji przemysłowej i usług, a przede wszystkim rolnictwa jest wynikiem pracy liczącej prawie $900 \mathrm{mln}$ armii zatrudnionych w chińskiej gospodarce. Oznacza to, że średnio tę samą jednostkę PKB wytwarza w Chinach czterech pracujących, a w USA jeden. W rolnictwie ta relacja jest jeszcze gorsza na niekorzyść Chin, szczególnie w produkcji roślinnej.

Obecne kierownictwo KPCh i ChRL pod wodzą XI Jinpinga zasadniczo kontynuuje reformy Deng Xiaopinga i realizuje długofalową politykę szybkiego zmieniania oblicza gospodarczego i socjalnego Chin, przy czym ze względu na światowy kryzys, który także częściowo dotknął Chiny, polityka ta jest trudniejsza i skomplikowana, ale ChRL osiągnęła obecnie już taki potencjał, że Stany Zjednoczone to właśnie państwo postrzegają jako główne zagrożenie dla swego panowania, a właściwie dominacji i hegemonii w świecie. Potwierdzają

73 Z. Wiktor, Chiny na drodze socjalistycznej modernizacji..., op.cit., s. 305. 
to zmiany gospodarcze i w handlu międzynarodowym, np. w dziedzinie produkcji, wymiany handlowej, a także polityki obronnej. Chiny osiągnęły gospodarkę i pozycję międzynarodowo-polityczną, że z pełną odpowiedzialnością zgłaszają się do pozycji jednego ze światowych liderów, który ma warunki i chce ponosić odpowiedzialność za losy całej planety.

Chiny są nowym liderem świata, dysponującym nie tylko wielkim potencjałem ekonomicznym, także reprezentuje inny typ państwa. Jest to państwo socjalistyczne, mające za podstawę ideowo-polityczną teorię marksizmu-leninizmu, wzbogaconą w ciągu ostatnich czterdziestu lat o myśl Mao Zedonga, teorię Deng Xiaopinga i kolejnych przywódców chińskich, obecnie myśl Xi Jinpinga, które złożyły się na oryginalną koncepcję budownictwa socjalizmu w państwie historycznie biednym, ekonomicznie zacofanym. Ale dzięki pracy kilku pokoleń Chińczyków zasadniczo zmieniło się oblicze kraju i doświadczenie to może być przykładem dla innych narodów, szczególnie słabo rozwiniętych, wstępujących na drogę rewolucyjną. Stawia to kwestie socjalizmu na nowym poziomie.

Jednocześnie trzeba wskazać na realne i potencjalne zagrożenia. 2/3 gospodarki znajduje się w rękach kapitału prywatnego krajowego i zagranicznego. Pogłębia się rozwarstwienie klasowe. Na szczytach nowej odrodzonej burżuazji jest potężna grupa miliarderów i milionerów, licząca swe bogactwa nie w juanach, lecz w dolarach. Co prawda nie ma ona możliwości zdyskontowania politycznego swej przewagi ekonomiczno-finansowej, ale bez wątpienia ma wpływy oficjalne i nieoficjalne na politykę ChRL. Wielkim zagrożeniem jest wszechobejmująca korupcja. Jest to więc ustrój nazywany przez niektórych uczonych jako kapitalizm państwowy. Powstała swoista hybryda, w której baza zdominowana jest przez prywatny kapitał a nadbudowa przez komunistów i ich sojuszników. Rodzi to cały szereg nowych sprzeczności, które, jak dotąd, są skutecz- 
nie rozwiązywane przez KPCh, ale sytuacja ta nie może trwać wiecznie i obecne kierownictwo KPCh stara się umocnić siły prosocjalistyczne, przede wszystkim w samej partii.

Podstawowym walorem tej sytuacji w kategoriach międzynarodowych jest to, że za sprawą socjalistycznych Chin pojawiło się nowe wielkie mocarstwo socjalistyczne, które jest realną alternatywą dla kapitalizmu i odpowiedzią na knowania imperializmu. Jest wyzwaniem dla tych sił, a jednocześnie jawi się jako realna nadzieja dla narodów uciśnionych, wyzyskiwanych, głównie postkolonialnych, które za sprawą ludowych Chin patrzą z większym optymizmem na możliwość poprawy swego położenia. Tak można odczytać wielką inicjatywę gospodarczą Chin w postaci nowych szlaków jedwabnych, adresowaną głównie do biednych państw Azji, Afryki, Ameryki łacińskiej, ale także dla Rosji i Europy Środkowo-Wschodniej.

\section{Socjalistyczna gospodarka rynkowa a konfucjanizm}

W dotychczasowej analizie socjalistycznej gospodarki rynkowej w Chinach jedynie incydentalnie pojawiała się kwestia jej relacji do konfucjanizmu, ale kwestia jest bardziej złożona i wymaga bliższej analizy i objaśnienia. Prawdą jest, że Deng Xiaopingowi przyświecała idea wykorzystania kapitalizmu wewnętrznego a przede wszystkim zagranicznego dla rozwoju i wzmocnienia gospodarki Chin. Nieodzownym warunkiem tej polityki było szerokie otwarcie się Chin na świat zewnętrzny. Oznaczało to, że do Chin napłynęły nie tylko obce kapitały i rozwinęła się własna inicjatywa prywatna. Siłą rzeczy napłynęły bądź odrodziły się inne niż marksistowsko-leninowska i maoistyczna ideologia, socjalistyczne koncepcje życia, gospodarki i międzynarodowych stosunków. Znalazło to wyraz w wymianie nie tylko gospodarczej czy handlowej, także ludzi 
kultury, nauki, studentów kształconych na zagranicznych uniwersytetach, w związku z tym pewna część obywateli ChRL zetknęła się z ludźmi, którzy nie darzyli sympatią ludowych Chin, a nawet ostro krytykowali jej ustrój z pozycji burżuazyjno-kapitalistycznych. Na uniwersytetach pojawiły się książki z nauk społecznych, przedstawiające doktryny liberalne, technokratyczne, socjaldemokratyczne itp., które z jednej strony przedstawiały pluralizm myśli społecznej na Zachodzie, z drugiej zaś zachęcały chińskich zwolenników tych rozwiązań do dyskutowania o możliwościach ich zastosowania w ChRL. O tym, że takie sytuacje miały miejsce świadczą postacie dysydentów chińskich, np. Liu Xiaobo, wymiana z ośrodkami licznej chińskiej diaspory w USA, Europie Zachodniej czy w Australii. Co można zrobić w takiej sytuacji, można takie poglądy i postacie izolować, a nawet zwalczać administracyjnie, ale są to nienajlepsze środki.

W tej sytuacji władze Chin zdecydowały się w ostatnich latach na wykorzystanie własnych postaci z nauki i kultury na wzbogacenie argumentów oraz autorytetów w dyskusjach o socjalizmie, przy czym są one dalekie od naukowego socjalizmu rodem z Europy. Ponownie sięgnięto do Konfucjusza. Więcej nawet, postanowiono wykorzystać autorytet postaci Konfucjusza jako jednego z największych filozofów chińskich dla umocnienia pozytywnego wizerunku ludowych Chin we współczesnym świecie, który od wieków znany był poza granicami Chin obok drugiego produktu narodowego mianowicie chińskiego jedwabiu. Dziś Chiny są znane z wielu innych osiągnięć gospodarczych, w zakresie elektroniki i wielu innych dziedzin. Towary chińskie dosłownie zalewają cały świat i USA i inne państwa kapitalistyczne nie zawsze są w stanie konkurować z tanią chińską produkcją. Świat stoi na progu nowej wojny handlowej, spór dotyczy kilkasetmiliardów, a może obecnie i biliona dolarów. Jest to jedna z głębokich różnic i sprzeczno- 
ści dzielących świat kapitalistyczny i Chińską Republikę Ludowa, przy czym sprzeczność między USA dotyczy także innych państw kapitalistycznych.

Świat wkracza w epokę rywalizacji nowych gigantów. Kapitalizm liberalny należy do przeszłości, stoi on w obliczu przejścia od imperializmu do kapitalizmu oligarchicznego, wykorzystującego metody autorytarno-administracyjne do kierowania nie tylko społeczeństwem, także gospodarką. W tej sytuacji Chiny choć są wielką potęgą gospodarczą i depczą po piętach USA i Unii Europejskiej muszą jeszcze bardziej zwierać szeregi i zwiększać wysiłek społeczny. Ich podstawowym problemem jest niska wydajność pracy, ok. 4,5 razy mniejsza niż w USA czy w rozwiniętych państw europejskich, nie mówiąc o rolnictwie, gdzie jest ona kilkadziesiąt razy mniejsza. Przed Chinami stoi ambitne zadanie osiągnięcia przodownictwa w innowacjach i nowoczesnej produkcji, opanowania nowych technologii, elektronicznego sterowania gospodarką itp. Chińskie plany przewidują opanowanie tych celów w dwóch etapach: do 2034 i 2035-2050 r. W tej sytuacji podstawową wartością i przewagą Chin jest socjalistyczna gospodarka rynkowa, planowanie makroekonomiczne i scentralizowany ustrój polityczny, który nie dopuszcza do powstawania antagonistycznych sprzeczności społecznych i nastawiony jest na poszukiwanie elementów spajających różne klasy, warstwy i grupy społeczne. Podstawową zasadą jedność, postęp, kwitnąca bezkryzysowa gospodarka, pojawiły się nieznane kiedyś zagrożenia, jak terroryzm, brak bezpieczeństwa socjalnego dla dziesiątków milionów, bandytyzm, pogarda dla świata pracy. W USA słyszy się coraz więcej głosów nie tylko z kręgów KP USA (m.in. senator Berni Sanders z Partii Demokratycznej), że jedynym lekarstwem na te dolegliwości Ameryki jest socjalistyczna rewolucja. Dziś wydaje się to niemożliwe, ale pamiętajmy, że przemiany w obecnej epoce odbywają się milowy- 
mi krokami. W tej ideowo-politycznej konfrontacji (nie tylko gospodarczo-handlowej) niemałą rolę odgrywają Chiny, które poprzez strategię nowych szlaków jedwabnych integrują wokół siebie ponad 150 państw Azji, Afryki i Ameryki Łacińskiej. Znajduje to wyraz głównie w olbrzymim eksporcie kapitałów na te rynki, rzędu ok. 8 bln dol., które mają znaczenie nie tylko jako wymiana handlowo-gospodarcza, za tym idą także pewne elementy chińskiego modelu ideowo-ustrojowego, co znajduje wyraz w próbach adaptacji niektórych rozwiązań polityczno-ustrojowych przez te państwa. Pierwszym kierunkiem rosnącej współpracy są liczne państwa azjatyckie, z którymi Chiny kooperują już od dawna, np. w ramach Aseanu, ale przede wszystkim Szanghajskiej Organizacji Współpracy. Azja to największy kontynent świata, obejmuje on ponad $60 \%$ ludności i 1/3 światowego PKB, średni poziom rozwoju państw azjatyckich jest dwukrotnie większy niż światowy. Środek ciężkości światowej gospodarki coraz bardziej przenosi się do Azji, która staje się wiodącym kontynentem w basenie Pacyfiku. W maju 2019 r. w Pekinie odbyła się wielka konferencja przedstawicieli ponad czterdzieści państw na temat dialogu azjatyckich cywilizacji. Spotkanie to można odczytać jako próbę łagodzenia i usuwania istniejących sprzeczności między nimi i budowania nowych płaszczyzn współpracy ${ }^{74}$.

Konfucjanizm, a w każdym razie jego niektóre idee i kategorie, także postacie, są wykorzystywane prze/z współczesną KPCh dla umocnienia pozycji partii i jej polityki. Wspomniano o Konfucjuszu, jego imieniem nazwano instytuty Konfucjusza, których jest już ok. jednego tysiąca na świecie. Są to instytucje formalnie podporządkowane chińskiemu Ministerstwu Spraw Zagranicznych i jako takie nie podlegają lokalnej administracji. Korzystają ze specjalnego statusu prawnomiędzynarodowego.

74 Więcej na ten temat zob. Catalyst For Renewal. Dialogue between Asian civilisations pools wisdom for a better shared future, „Beijing Review”, 21.05.2919, nr 21, s. 12-16. 
Z reguły są usytuowane przy miejscowych uniwersytetach, nosząc status autonomicznej jednostki organizacyjnej szkoły wyższej. Zarządzane są przez dwóch dyrektorów: chińskiego i miejscowego, najczęściej pracownika naukowego. Ich podstawowym zadaniem jest szeroka informacja o kulturze i gospodarce Chin, historii i nauce języka. Instytuty Konfucjusza są jednym z licznych przykładów tzw. soft power w polityce międzynarodowej. Żadna inna postać chińskiej kultury nie nadaje się bardziej na patrona tej instytucji jak właśnie Konfucjusz. W ten sposób wielki filozof starożytnej idealistycznej filozofii chińskiej, jednocześnie pośrednio współtwórca religii konfucjańskiej, wykorzystany został przez KPCh i ludowe Chiny dla promocji korzystnego wizerunku Chin w środowiskach zagranicznych, szczególnie wpływowych wśród młodzieży studiującej, także szeroko rozumianej inteligencji, instytuty służą także pomocą biznesmenom, np. w zakresie nauczania języka chińskiego, zasad negocjacji z chińskimi biznesmenami itp. ${ }^{75}$ Konfucjanizm wykorzystywany jest także dla umocnienia autorytetu partii komunistycznej, np. kult silnej scentralizowanej władzy państwowej, poszanowanie dla przywódców państwowych, obecnie bardzo ważnym hasłem polityki KPCh jest zasada rządów prawa, do tego dążył i takiego państwa oczekiwał Konfucjusz w głębokiej starożytności, także legiści. Innymi kategoriami są chińskie marzenie („chiński sen”), ostatnio bardzo rozpowszechniane przez Przewodniczącego ChRL Xi Jinpinga nie tylko na użytek dialogu wewnętrznego, także jako atrakcyjna alternatywa chińskiego sposobu życia, w szczególności chińskiego marzenia w konfrontacji z amerykańskim marzeniem. Ta kwestia ma duże znaczenie ideologiczne w sytuacji nieustannej konfrontacji amerykańskiego sposobu życia

75 Więcej na temat popularyzacji wiedzy o chińskich klasycznych filozofach zob. An Introduction to Chinese Classics: Confucianism, Taoizm And Buddhism..., op.cit., w szczególności s. 30 i n. 
(american way of life) $\mathrm{z}$ chińskimi warunkami materialnymi i duchowymi. Znaczna część studiującej młodzieży na amerykańskich uniwersytetach, także turystów wyjeżdżających na Zachód lub nawet do Hongkongu, na Tajwan czy do Singapuru łatwo przyjmuje wartości, a głównie wzorce zachowań amerykańskiego sposobu życia i jest to pewien problem ideowo-behawioralny dla KPCh. Aktualne jest pytanie jakie wzory zachowań i wartości chińskich mogą być konkurencyjne wobec ofensywnie lansowanego przez ośrodki burżuazyjne nie tylko USA american way of life ${ }^{76}$.

W kwestii relacji i przenikania się konfucjanizmu i marksizmu autor artykułu wielokrotnie dyskutował z licznymi uczonymi chińskimi podczas pobytów naukowo-dydaktycznych na Uniwersytecie Wuhan, także ze studentami. Wskazywano, że jest to proces o różnym nasileniu interakcji. Konfucjanizm był główną ideologią cesarskich Chin, zatem po ich upadku radykalnie stracił na znaczeniu, upadły główne siły społeczne zainteresowane w jego umacnianiu i trwaniu. Okres 1. Republiki nie wyeliminował całkowicie konfucjanizmu z życia publicznego, sprzyjała mu część dawnych klas wyższych, mandarynów przekształconych w różnych urzędników, którzy zawsze byli ważni w życiu społecznym, także wojsko, szczególnie wyżsi wojskowi byli zainteresowani w utrzymaniu konfucjanizmu jako środka na posłuszeństwo i utrzymania w ryzach żołnierzy. Znamienne jest, że do konfucjanizmu przyznawał się wielokrotnie pierwszy Prezydent Chińskiej Republiki Sun Yatsen. Masowo krążyły różne powiedzenia i przypowieści Konfucjusza i jego uczniów, także z późniejszych wieków, które były ważnymi argumentami w prowadzonych dyskusjach. M.in. wspominał o tym w rozmowie z amerykańskim dziennikarzem Snow w latach 30. XX w. Mao Zedong, mówiąc o swym wychowaniu w domu rodzinnym

76 Xi Jinping, The Governance of China, t. 1, Beijing, , 2018, s. 37 i n. 
i pobieraniu mądrości konfucjańskich w ówczesnych szkołach w Shaoshan i Changsha.

Znamienne było, że także w szeregach KPCh w trakcie walk partyzanckich i w okresie jenańskim ciągle aktualna była kwestia braku wykształconych kadr marksistowskich. Niektórym działaczom niższego szczebla wytykano braki w znajomości marksizmu i posługiwanie się argumentacją czerpiącą z konfucjanizmu. Wszystko to można zrozumieć w sytuacji braku szkół, podręczników, wykwalifikowanych kadr, w związku $\mathrm{z}$ tym poziom ideowo-polityczny partii podnoszono $\mathrm{w}$ rezultacie samokształcenia i w ogniu realnej walki klasowej, prowadzonej w formie walki partyzanckiej przeciwko własnym wrogom klasowym, jak i japońskim najeźdźcom. Jednocześnie wysokie stanowiska w partii coraz częściej pełnili towarzysze kształceni na Uniwersytecie Sun Yatsena (Narodów Wschodu) w Moskwie, gdzie uczono marksizmu-leninizmu w oparciu o kadry i doświadczenie rewolucyjnej Rosji i Związku Radzieckiego. Niektórzy najwyżsi przywódcy np. Zhou Enlai i Deng Xiaoping, przebywali przez wiele lat na Zachodzie, np. we Francji, gdzie pracowali i studiowali marksizm w szkołach KPF. Po zwycięstwie rewolucji w 1949 r. sytuacja zmieniła się zasadniczo. Nastąpił szybki rozwój marksizmu, jednocześnie adaptowano go do warunków historycznych, gospodarczych, społecznych i kulturowych Chin, co z czasem przybrało postać doktryny (myśli) Mao Zedonga (maoizm). Jak już wspomniano Mao prowadził bezkompromisową walkę z konfucjanizmem jako filozofią, religią i obyczajowością. Sytuacja zasadniczo zmieniła się w następnym okresie, o czym już wspomniano ${ }^{77}$.

77 Z wcześniejszych autorów, którzy analizowali społeczno-polityczną i filozoficzną doktrynę maoizmu zob. J. Borgosz, Próba filozoficznej analizy maoizmu, [w:] Chińska Republika Ludowa. Ideologia, polityka, gospodarka, oprac. J. Borgosz, E. Krawczyk, S. Łysko, J. Muszyński, J. Sokół, A. Żebrowski, Warszawa 1979, s. 45-110. 
Na temat miejsca konfucjanizmu w Chinach i jego adaptacji do ideologii KPCh autor rozmawiał też z uczonymi z uniwersytetów europejskich, będących w tym samym czasie na Uniwersytecie Wuhan. Odpowiedzi były bardzo zróżnicowane. Najbardziej szły pod tym względem wypowiedzi uczonych rosyjskich, z których jeden wyraził opinię, że w obecnej ideologii KPCh konfucjanizm obejmuje 90\%, a marksizm, nawet schińszczony tylko $10 \%$. Inni obstawali przy zdaniu, że jest 50 do $50 \%$ i że nawet w czasach Mao konfucjanizm nie został nawet w KPCh całkowicie wyeliminowany, o czym świadczyły ostre spory ideowe i zarzuty pod adresem przeciwników politycznych, że ulegają konfucjanizmowi. Tak czy inaczej, zdania są podzielone, ale wszystkie wskazywały na rosnący udział w ideologii KPCh konfucjanizmu. Autor artykułu uważa, że wymienione oceny są przesadzone, ale bez wątpienia konfucjanizm nigdy nie został przezwyciężony w KPCh i ma obecnie tendencję wzrostową. Pytanie jest takie, czy mógł on być całkowicie wyeliminowany w sytuacji diametralnie odmiennej drogi rozwojowej Chin, odrębnej kultury i cywilizacji. Nie było takich kategorii, jak proletariat, który zastąpiono ludem, także rewolucji, którą zastąpiono „utratą mandatu nieba”, nie było także wielu innych pojęć, którymi posługiwał się marksizm, a później leninizm. Zasadniczo odmienna była struktura społeczno-klasowa, wynikająca w części z kontynuacji azjatyckiego sposobu produkcji, jak i skostniałego chińskiego ustroju feudalnego, który nadal tkwił w niektórych strukturach po obaleniu cesarstwa, ale głównie w świadomości mas społecznych.

Pewną przesłanką obecności konfucjanizmu w ideologii KPCh były niektóre jego zasady i wartości (niezależnie od idealizmu), które go zbliżały do niektórych treści marksizmu, szczególnie w jego warstwie socjalnej, np. humanitarność (ren), każdy na swym miejscu ma być otoczony opieką, władca ma roztaczać opiekę nad poddanymi, rodzice nad dzieć- 
mi (ojciec nad synem), mąż nad żoną, cesarz nad państwem. W związku z tym pojawiają się nawet poglądy, że Konfucjusz był pierwszym chińskim marksistą. Przypomina to argumenty niektórych europejskich socjalistów utopijnych, którzy postrzegali Chrystusa jako pierwszego socjalistę. Głównie jest przytaczana nauka mistrza dla młodzieńca, pytającego jak żyć, odpowiedział mu: rozdaj swoje bogactwo biednym i pójdź z nami. Inna wypowiedź przestrzegająca, że łatwiej jest przejść wielbłądowi przez ucho igielne niż bogaczowi do Królestwa Niebieskiego. Oczywiście to egalitarne warunki życia pierwszych gmin chrześcijańskich tworzyły równościowe standardy i warunki życia pierwszych wiernych Chrystusa, którzy wywodzili się głównie z warstw najbiedniejszych, niewolników, a więc „komuna” była ich naturalnym sposobem życia. Problem polegał jednak na tym, że Chrystus głosił, że królestwo jego nie jest z tego świata i w przeciwieństwie do żyjącego mniej więcej 100 lat wcześniej Spartakusa nie wskazywał siły społecznej, która mogła dokonać buntu, głównie niewolników i budować gdzieś na Wschodzie swoje społeczeństwo sprawiedliwości społecznej. Niestety nie było mu dane zrealizować ten eksperyment społeczno-rewolucyjny, po dwóch latach powstańcy zostali rozbici przez zawodowe wojsko rzymskie, a Spartakus i inni przywódcy oraz duża część niewolników zostali zamordowani przez ukrzyżowanie.

Na temat relacji marksizmu i konfucjanizmu ukazał się ciekawy artykuł Josefa Gregory Mahoney'a pt. Marx and Confucius. The intersections between communism and datong, opublikowany na łamach „Beijing Review” w maju 2018 r. ${ }^{78}$ Warto przytoczyć niektóre jego argumenty.

Zdaniem autora rozwój marksizmu w Chinach poszedł drogą odwołania się nie tyle do konkretnej klasy społecznej (robot-

78 J.G. Mahoney, Marx and Confucius, The intersections between communism and datong, „Beijing Review”, 10.05.2018, nr 19, s. 32-33. 
niczej) jako potencjalnej siły buntowniczo-rewolucyjnej, której historycznym zadaniem jest obalenie kapitalizmu i budowa socjalizmu. Główną przyczyną była znikomość liczbowa tej rodzącej się dopiero klasy społecznej i brak rewolucyjnego doświadczenia i przygotowania. Próby organizowania partii komunistycznej i organizowania powstania w oparciu o środowisko miejskiego proletariatu zakończyło się w 1927 r. masakrą dokonaną przez wojska Czang Kajszeka. Wyciągnął z tego wnioski organizacyjne Mao Zedong i przez następne lata odbudowywał partię w oparciu o biedne chłopstwo i proletariat wiejski. Inaczej niż w Rosji radzieckiej, gdzie rewolucja była dziełem fabrycznego proletariatu, a później wkroczyła na wieś. W Chinach rewolucja zwyciężyła na wsi i otaczała miasta, doprowadzając w 1949 r. do zwycięstwa. Dlatego w Chinach rozwój marksizmu poszedł drogą odwołania się do chińskiej wrażliwości społecznej w kwestii oryginalności, unikatowości, różnorodności i odmienności ich dróg rozwoju historycznego.

Kwestia ta ma trzy aspekty:

1. Wizja sprawiedliwości społecznej wprowadzona do nauki przez Marksa jako kategoria par excellence naukowa konweniuje bezpośrednio z chińską koncepcją „datong shehui”, co można przetłumaczyć jako społeczeństwo „Wielkiego Kursu” (drogi, kierunku) lub „Wielkiej Jedności". Kategoria ta wyraża fundamentalny teleologiczny cel ludzkości (identyfikowany z socjalizmem) opisany już przed 2500 lat przez Konfucjusza w księdze Li Ji, czyli w Księdze rytów (obrzędów), który przedstawia się niżej.

2. Wizja ta rozwijana była nie tylko przez zwolenników konfucjanizmu. Znalazła także żywy oddźwięk w następnych czasach wśród zwolenników taoizmu, który definiował podstawowe prawo dialektyki jako nieustanną walkę, rozwiązującej sprzeczności. Prawa dialektyki są immanentne dla współczesnej filozofii i wyrażają się głównie 
w zasadzie jedności i walki przeciwieństw przechodzenie zmian ilościowych w jakościowe i inne. Zwolennicy konfucjanizmu i taoizmu uważają, że dialektyka tworzy pomost poznawczy między dawnymi i współczesną epoką. Współczesny świat potrzebuje porządku i stabilizacji, by zapewnić ludzkości dalszy rozwój, zmiany i postęp społeczny. Dzisiejszy czas jest także okresem walki i współzawodnictwa między kapitalizmem a socjalizmem. Oba ustroje stawiają sobie inne cele społeczne, gospodarcze oraz polityczne i ta prawidłowość znalazła wyraz w perspektywicznym programie rozwoju społecznego KPCh, który jest konsekwentnie realizowany przez Chińską Republikę Ludową. W tym zakresie komuniści chińscy oparli się nie tylko na dorobku marksistowskim, ale sięgnęli także do konfucjańskiej koncepcji „xiaokang shehui”, tłumaczonej jako „umiarkowanie zamożne społeczeństwo", koncepcji do której z konsekwencją sięga obecny sekretarz generalny KPCh i Przewodniczący ChRL Xi Jinping i która znalazła pełne uznanie w podstawowym dokumencie XIX Zjazdu KPCh w październiku 2017 r.

3. Kategorie „datong” (wielki kurs) i „xiaokang shehui” (umiarkowanie zamożne społeczeństwo) zostały wykorzystane przez obecne kierownictwo KPCh jako sposób na potwierdzenie odwiecznych dążeń ludu chińskiego do równości i sprawiedliwości społecznej, które w poprzednich epokach z powodu klasowych nierówności i niedostatecznych warunków rozwojowych nie mogły być zrealizowane. Obecnie Chiny znajdują się na drodze budowy socjalizmu i w dalszej perspektywie komunizmu i perspektywa stworzenia równościowego i sprawiedliwego społeczeństwa nabiera realnych kształtów (choć stawiają ją pod znakiem zapytania pogłębiające się od pewnego czasu nierówności społeczne). Koncepcje te są także 
ważne dla zrozumienia i zdefiniowania cech świadomości chińskiej, wyrażonej w kategorii „yinyang”, osadzonej historycznie na podstawach idealistycznej filozofii ${ }^{79}$.

Marzenia ludzkości o lepszym, sprawiedliwym i egalitarnym społeczeństwie miały odwieczny charakter, ale w Europie poczynając od XVIII w. wraz z potężnym rozwojem sił wytwórczych, głównie przemysłu, przyczyniły się do rozwoju nauk, co zaowocowało powstaniem epoki oświecenia, upadkiem reżimów feudalnych i burżuazyjnymi rewolucjami społecznymi. Procesy te z różnym nasileniem rozwijały się wcześniej w Niderlandach, północnych Włoszech, Anglii, we Francji, a na półkuli zachodniej w koloniach angielskich. Przemianom tym towarzyszyły szybkie zmiany w strukturze klasowej rodzącego sie nowego społeczeństwa klasowego, w którym podstawową sprzecznością klasową była walka klasowa między burżuazją a proletariatem. Jednocześnie procesy te rodziły głębokie sprzeczności klasowe i postępującą nierówność klasową, bogacenie się garstki burżuazji i głęboką nędzę niższych warstw, głównie proletariatu. Rodziło to poczucie krzywdy społecznej i zachęcało klasy oraz warstwy uciskane i wyzyskiwane do walki o poprawę sytuacji społeczno-ekonomicznej i położenia prawnego. Na tym tle rodził się ruch robotniczy, który najpierw walczył o podstawowe prawa socjalne (klasa w sobie), a później uzbrojony w teorię naukowego socjalizmu, dążył do rewolucyjnego obalenia kapitalizmu i powstania państwa socjalistycznego, które byłoby w stanie ostatecznie znieść przeciwieństwo klasowe między pracą a kapitałem i budować ustrój sprawiedliwości społecznej (klasa dla siebie).

Droga do ukształtowania się rewolucyjnego ruchu robotniczego była długa i pełna meandrów ideowo-politycznych, wymagała także rozwoju kapitalizmu w skali kontynentalnej

79 Ibidem, s. 32. 
i światowej oraz łączyła się z powstaniem partii robotniczych, które w końcu XIX w. miały głównie socjaldemokratyczny charakter. Wielkie zasługi w ich rozwoju odegrali Marks i Engels, którzy już w latach 40. XIX w. w oparciu o rozwój kapitalizmu w Anglii i doświadczenia angielskiego ruchu robotniczego sformułowali tezę o możliwości i konieczności obalenia kapitalizmu przez nową siłę rewolucyjną, jaką stawał się proletariat przemysłowy. Było to doniosłe odkrycie rodzącego się naukowego socjalizmu, który w rozwoju sił wytwórczych, sprzecznościach kapitalistycznych dostrzegał nową siłę klasową, zdolną do obalenia kapitalizmu i powstania równościowego socjalizmu. Naukowy socjalizm różnił się zasadniczo od socjalizmu utopijnego, który od czasu oświecenia rozwijał się jako wyraz dążeń społecznych ze strony oświeconych filozofów, by w oparciu o dobrą wolę uczonych i bogatych mężów dzieliliby się własnymi środkami, by łagodzić pogłębiające się sprzeczności kapitalistyczne. Wybijającymi się postaciami w gronie socjalistów utopijnych byli już w XVI w. Tomasz Morus (Utopia) i T. Campanella, we Francji w okresie oświecenia G.B. Mably i Morelly, a później C.H. Saint-Simon i Ch. Fourier i R. Owen w Anglii. Ich podstawową słabością były przekonania o możliwości zmiany społeczeństwa na bardziej humanitarne dzięki racjonalnym argumentom i dobrej woli bogatszej części społeczeństwa. Przełomem w tym zakresie stała się dopiero analiza rozwoju społecznego dokonana przez Marksa i Engelsa w końcu lat 40. XIX w., która dowodziła, że dotychczasowa historia społeczeństw jest historią walk klasowych i w dobie kapitalizmu jego sprzeczności jest w stanie rozwiązać w rezultacie rewolucji rosnący w siłę proletariat, jako główna siła antagonistyczna wobec burżuazji. Koncepcje Marksa i Engelsa oparte były na podstawach filozofii materialistycznej, przede wszystkim materializmie dialektycznym i historycznym, które postawiły kwestię dążeń do ustanowienia ustroju sprawiedli- 
wości społecznej na podstawach naukowych i zdefiniowały klasę robotniczą (proletariat), lud pracujący, która obiektywnie i subiektywnie predystynowana jest do realizacji tej wielkiej misji historycznej.

Koncepcje te trafily na początku XX w. do Chin i rozwijane były przez chińskich marksistów, spośród których należy wymienić Zhu Zhixin, który już w 1905 r. przedstawił szczegółowo drogę życiową Marksa i Engelsa oraz podstawowe treści Manifestu komunistycznego. W 1912 r. przetłumaczono na chiński wstęp do pracy Engelsa o socjalizmie naukowym i utopijnym. Faktycznie jednak przyswojenie marksizmu w Chinach nastąpiło po rewolucji październikowej w Rosji, kiedy okazało się, że rosyjski proletariat mógł nie tylko obalić zmurszały carski ustrój, ale także zdobyć władzę i zapoczątkować budowę socjalizmu. Wielkim marksistą tej epoki był Chen Duxiu, który miał duże zasługi w dalszym propagowaniu marksizmu, także Li Dazhao, Hu Shi i inni, którzy przygotowali grunt dla powstania kilku grup marksistowskich w Chinach i założenia w lipcu 1921 r. Komunistycznej Partii Chin. Od tego czasu marksizm w Chinach rozwijany był głównie przez komunistów, wśród których bez wątpienia wybijał się jeden ze współzałożycieli KPCh i późniejszy jej przywódca Mao Zedong ${ }^{80}$.

Pierwsi chińscy marksiści stali przed wielkimi problemami ciągłości i bogactwa chińskiej myśli społecznej, rozwijającej się od 3 tysiąclecia przed naszą erą, spętanej jednak kostycznością, izolacją od świata zewnętrznego Państwa Środka. Położenie i ukształtowanie geograficzne, warunki klimatyczne i wodne wpłynęły na powstanie odmiennego typu państwa antycznego, zwanego przez klasyków marksizmu azjatyckim typem produkcji i towarzyszący mu z reguły scentralizowany i despotyczny ustrój państwowo-polityczny. Na bazie tego ustroju wykształ-

80 Więcej na temat początków marksizmu w Chinach zob. Zheng Hangsheng, Li Yingsheng, Historia chińskiej socjologii, Toruń 2010, s. 125 i n. 
ciła się unikatowa w starożytności funkcja organizatorska państwa, niezbędna dla prowadzenia scentralizowanej gospodarki wodnej, budowy kanałów nawadniających, osuszania terenów błotnistych i nawadniania terenów stepowych i pustynnych. Do tych przedsięwzięć należała także budowa wielkich kanałów, mających nie tylko znaczenie rolnicze, ale także komunikacyjne, handlowe i militarne. Przejawem tej funkcji były również wielkie inwestycje budowlane, nie tylko pałace władców, ich monumentalne grobowce z odlanymi bądź wyrzeźbionymi pomnikami tysięcy wojowników, monumentalne świątynie i liczące tysiące kilometrów obiekty obronne na północnych granicach - Wielki Mur Chiński, planowo realizowany od ponad 2 tys. lat układ dróg, łączący strategiczne miejscowości cesarstwa ze stolicą kraju. Chiny przez wiele epok historycznych były przodującym technicznie, militarnie i pod względem poziomu rozwoju gospodarczego państwem świata. Przewagę tę zaczęły tracić wraz z opanowaniem Chin przez Mandżurów i zainstalowaniem się w Pekinie obcej dynastii Qing (1644-1911). W tym czasie Europa Zachodnia przeżywała rozwój zapoczątkowany odkryciami geograficznymi, napływem do Europy wielkie ilości złota i innych bogactw oraz kształtowaniem się wczesnego kapitalizmu. W Niderlandach i Anglii już w XVI i XVII w. odbywały się pierwsze rewolucje burżuazyjne, które usuwały bariery feudalne przed szybkim rozwojem nowego ustroju. Dzięki rozwojowi przemysłu, rewolucji technologicznej zapoczątkowanej takimi wynalazkami, jak maszyna parowa, nowe techniki wytopu metali, szczególnie żelaza, maszyny w przemyśle tkackim, radykalnie zwiększała się wydajność pracy, obrót finansowo-towarowy i początki ekspansji kolonialnej, szczególnie Korony Brytyjskiej i Niderlandów. Tymczasem Chiny ciągle tkwiły w strukturach gospodarczych feudalizmu, w którym głównym rodzajem wytwórczości było zacofane, a w niektórych rejonach archaiczne rolnictwo. Miasta miały głównie charakter admi- 
nistracyjno-wojskowy z pewnym udziałem rzemiosła i służb. Poczynając od początków XIX w. Chiny zaczęły być wyprzedzane przez państwa europejskie. Po wojnach napoleońskich przodownictwo zdobyła Anglia, która dawała ponad 50\% ówczesnej światowej produkcji przemysłowej, zdobywała liczne kolonie i terytoria zależne, które w ciągu 100 lat (po kongresie wersalskim) obejmowały ok. 1/4 obszaru świata. Pod koniec XIX w. dała o sobie znać w Azji rywalizacja między Anglią, Francją, Niemcami a Rosją. Na Dalekim Wschodzie rosła w siłę cesarska Japonia, a po drugiej stronie Pacyfiku umacniały się Stany Zjednoczone Ameryki. Chiny stały w obliczu nieuchronnej konfrontacji z mocarstwami imperialistycznymi, chyliły się coraz bardziej ku upadkowi, problemem był czas i rywalizacja o wpływy między mocarstwami. Wkrótce faktycznie utraciły niepodległość i stały się państwem półkolonialnym, w którym zaborcy wymusili liczne koncesje i zmuszali Chiny do odrywania nowych połaci kraju. Pod koniec XIX w. gotowy był tajny plan całkowitego podziału Chin przez cztery mocarstwa: Rosję, Anglię, Francję i Niemcy. Niedługo potem do stołu negocjacyjnego dopuszczona została Japonia. Nad Chinami zawisło realne niebezpieczeństwo wymazania Państwa Środka z mapy Azji.

Historyczny rozwój państwowości chińskiej przeżywał wzloty i upadki, można go zobrazować sinusoidą osiągania wielkiej mocarstwowej potęgi, osłabienia i rozpad na swoiste rozbicie dzielnicowe. Z czasem pojawiały się siły odrodzeniowe, które krzepły i rozpoczynały ponowny proces umacniania i centralizacji Chin. Te zmiany wyznaczały dzieje kolejnych panujących dynastii od legendarnej dynastii Xia poprzez osiemnaście innych do końca dynastii Qing, która obalona została w 1911 r. Obecnie można mówić o rządach demokratyczno-republikańskich: 1. republika burżuazyjna (1912-1949) i 2. republika ludowo-demokratyczna, rządzona przez Komunistyczną Partię Chin (1949-2019). Podstawą społeczną chińskiej pań- 
stwowości był i jest wielki naród chiński, kształtujący się przez wiele tysięcy lat, oparty na zdobyczach gospodarczych i kulturalnych odrębnej chińskiej cywilizacji, która spajała najpierw plemiona i szczepy, a w późniejszych epokach liczne narody i narodowości oraz promieniowała na sąsiednie państwa i narody. Cywilizacja chińska była bezcenną wartością i osiągnięciem kulturowym, które nawet w okresie osłabienia i rozdrobnienia państwa jednoczyła Chińczyków i nie pozwalała im się rozpłynąć w morzach innych cywilizacji i narodów. Dużą rolę w zachowaniu ciągłości rozwojowej chińskiej cywilizacji miało wyizolowane położenie geograficzne, oddzielające Chiny od innych narodów i cywilizacji. Od wschodu ocean i morza, od północy wielkie rzeki i tereny pustynne i półpustynne, później także Wielki Mur Chiński, od zachodu i południa wysokie góry, stanowiące trudną do sforsowania zaporę przed niebezpiecznymi sąsiadami. Legło to u podstaw odrębności i unikatowości cywilizacji Państwa Środka, która w przeciwieństwie do innych cywilizacji starożytności nie upadła, przekształciła się, unowocześniła i obecnie znajduje nowe siły dla odnowienia i oferowaniu światu zewnętrznemu unikatowych wartości kultury ${ }^{81}$.

Drugą wielką cechą odrębności i swoistą oryginalną instytucją chińską częściowo zachowaną do czasów obecnych, była wspólnota wiejska (gminna), która wykształciła się w najodleglejszych czasach powstawania cywilizacji chińskiej i nawet wyprzedzała powstanie państwa. Była ona reliktem dawnego społeczeństwa pierwotnych rolników, którzy stworzyli organizację samorządową, rządzącą się własnymi zasadami i prawami, dysponującą także władztwem gruntowym i zor-

81 Xi Jinping, The Governance of China..., op.cit., s. 7 i n.: Ji Jing, Catalyst For Renewal. Dialogue between Asian civilisations pools wisdom for a better shared future, „Beijing Reviw”, 23.05.2019, nr 21, s. 12-15, zob. też: Asian Governance Synergy, „Beijing Review”, 23.05.2019, nr 21, s. 16-17. 
ganizowaną w oparciu nie tylko o więzi pokrewieństwa i sąsiedztwa, także koniecznością i umiejętnością podejmowania wspólnego wysiłku na rzecz walki o przetrwanie, np. z żywiołem wodnym (powodzie), regulacją rzek, nawadnianie i inne niezbędne czynności dla prowadzenia prawidłowej gospodarki rolnej. Chodziło także o stawienie czoła innym katastrofom przyrodniczym, np. pustynnym wiatrom, trzęsieniom ziemi. Administracja chińskiego państwa od wieków nie obejmowała gmin wiejskich, rządziły się one własnymi prawami. Państwo zbierało podatki, brało także rekruta. Administracja państwowa zatrzymywała się na granicy dzisiejszych powiatów. Bez wątpienia ten fenomen organizacyjny gmin wiejskich wpływał na kształtowanie się umiejętności samorządzenia wśród chińskiego społeczeństwa chłopskiego, co wpłynęło także na poziom zorganizowania i świadomości społecznej także dzisiejszych Chińczyków.

Do tych wartości i etosu chińskich chłopów sięgnął na przełomie lat 20. i 30. XX w. Mao Zedong, odbudowując partię komunistyczną w oparciu o chłopsko-plebejski substrat społeczny, znający także jego pracowitość, wrażliwość na niesprawiedliwość i krzywdę społeczno-klasową, umiejętności organizowania się i samoobrony, które w okresach krytycznych sprzeczności łatwo przechodziły w bunty skierowane przeciwko ciemiężcom. Chińscy komuniści nawiązywali także do różnych doświadczeń ruchu robotniczego i demokratycznego, początkowo amerykańskiego, w szczególności Sun Yatsen, japońskiego ze względu na bliskość i uniezależnienie się Japonii od mocarstw kolonialnych, Francji - Czou Enlaj, Deng Xiaoping i wielu innych, Rosji i Związku Radzieckiego - Mao Zedong i cała grupa marksistów i komunistów kształconych na Uniwersytecie Sun Yatsena (Narodów Wschodu) w Moskwie, także w różnych instytucjach Międzynarodówki Komunistycznej w Związku Radzieckim. W tym okresie znaczące osiągnięcia teoretyczne były udziałem 
Qu Qiubaia, który wychodząc z materializmu historycznego przedstawił klasyfikację innych nauk społecznych, w tym socjologii, a także Li Da, który napisał wiele książek wyjaśniających liczne problemy społeczne Chin z pozycji materializmu historycznego. Opracował m.in. wykłady z „nowoczesnej socjologii", w której przedstawił rozwój społeczeństwa z pozycji materialistycznych. Poświęcił także wiele uwagi budowie funkcji prognostycznej nauki. W tym czasie powstała empiryczna analiza struktur społecznych, której modelowym przykładem były badania struktur społecznych w „starych” Chinach, m.in. analiza klas na chińskiej wsi ${ }^{82}$.

Ma Zedong i jego współpracownicy po zwycięstwie rewolucji w 1949 r. znaleźli oparcie polityczne i gospodarcze w ZSRR. W grudniu 1949 r. Mao Zedong złożył wizytę w Moskwie wraz z liczną grupą ministrów i ekspertów. Rząd radziecki na czele ze Stalinem udzielili Chinom wieleset mln rubli pożyczki w złocie, zawarte zostały liczne umowy o budowie przez specjalistów radzieckich licznych nowoczesnych przedsiębiorstw, dróg, mostów i kolei, a także szeroką pomoc w zakresie kształcenia w radzieckich szkołach wyższych chińskich kadr i studentów. Zawarty został także układ o przyjaźni i wzajemnej pomocy wojskowej. W tym czasie Chiny ludowe czerpały pełną garścią z różnych form pomocy gospodarczej, finansowej i naukowej. Chińska Republika Ludową tworząc podstawy ustrojowo-konstytucyjne oparła się w dużym stopniu na praktyce ustrojowej ZSRR, czego wyrazem była Konstytucja ChRL z 1954 r., jej zasady ustrojowo-polityczne i struktura organów państwowych Chińskiej Republiki Ludowej. Sytuacja zaczęła się komplikować po śmierci Stalina w marcu 1953 r. Nowe

82 Więcej na ten temat zob. Badania nad strukturami społecznymi podejmowane przez szkołę marksistowską, [w:] Zheng Hangsheng, Li Yingsheng, Historia chińskiej socjologii..., op.cit., s. 301 i n. 
kierownictwo KPZR na czele z N. Chruszczowem zmieniło główne zasady polityki wewnętrznej i zagranicznej, odchodząc najpierw skrycie, a w późniejszych latach coraz bardziej otwarcie na pozycje nowego oportunizmu i reformizmu. Przedmiotem szczególnie ostrej krytyki stały się tzw. błędy i wypaczenia dawnego okresu, a przede wszystkim Chruszczow oskarżył Stalina o nadużywanie terroru w rządzeniu i kult jednostki. W polityce zagranicznej ZSRR zrezygnował z roli przywódcy światowego proletariatu i ograniczył się do roli obrony wielkomocarstwowych wpływów i interesów Związku Radzieckiego. Było to mocne osłabienie międzynarodowego ruchu komunistycznego i polityka nowego kierownictwa radzieckiego okazała się początkiem odwrotu od socjalizmu do kapitalizmu, co ostatecznie nastąpiło na przełomie lat 80. i 90. XX w. kiedy sekretarzem generalnym KPZR był M. Gorbaczow.

W latach 60. XX w. pojawiły się głębokie rozdźwięki między KPCh a KPZR. Wielkim wstrząsem były tzw. „rewelacje” Chruszczowa o Stalinie wygłoszone w jego "tajnym referacie” na XX Zjeździe KPZR w lutym 1956 r. Przez kilka lat KPCh próbowała powstrzymać złowieszczy trend w KPZR, ale różnice pogłębiały się i obejmowały cały międzynarodowy ruch komunistyczny. Drogi obu partii rozeszły się na początku lat 60 . XX w. Nastąpiło wyraźne ochłodzenie wzajemnych stosunków, różnice dotyczyły nie tylko kwestii ideologicznych, były także politycz$\mathrm{ne}, \mathrm{w}$ aspekcie polityki zagranicznej i gospodarczej. Zerwana została współpraca wojskowa, a nawet w drugiej połowie lat 60 . doszło do małego konfliktu zbrojnego nad rzeką Ussuri, co było spowodowane przez lewacką i awanturniczą politykę marszałka Lin Biao. Chiny w tym czasie wstąpiły w okres dużego zamętu politycznego i chaosu gospodarczego, spowodowanych przez politykę tzw. Wielkiego Skoku, a później wielkiej rewolucji kulturalnej. W tym czasie KPCh zaczęła aspirować do roli światowego przywódcy międzynarodowego ruchu komunistycznego, 
co nie miało wówczas szans powodzenia ze względu na słabość ekonomiczną Chin i niski autorytet KPCh na arenie międzynarodowej. Wtedy też zaczęły kształtować się ideowo-polityczne przesłanki odrębności ideologicznej KPCh i podkreślania oryginalności i specyfiki chińskiej drogi do socjalizmu, co znalazło wraz w lansowaniu maoizmu jako nowej ideowo-politycznej postaci marksizmu.

Procesy te uległy przyspieszeniu po śmierci Mao Zedonga w 1976 r., eliminacji z kierownictwa KPCh tzw. „bandy czworga” i objęcia kierownictwa partią przez Deng Xiaopionga. Od 1978 r. zapoczątkował no realizację nowego kursu, którego jądrem była później sformułowana kategoria „socjalistyczna gospodarka rynkowa" ${ }^{83}$, która wydawała się zaprzeczeniem socjalizmu. Deng Xiaoping potrafił jednak przekonać większość gremiów kierowniczych dla celowości tego rozwiązania. Historia przyznała mu rację i po czterdziestu latach KPCh i ludowe Chiny święcą triumfy, są drugą gospodarką świata. Wraz z upowszechnianiem się tej kategorii, a bardziej praktyki historycy starej chińskiej filozofii przypomnieli sobie o konfucjańskiej koncepcji wspomnianej już „xiaokang shehui”, czyli umiarkowanie zamożnego społeczeństwa, które w całej pełni wykorzystane zostało przez aktualne kierownictwo KPCh na czele z Xi Jinpingiem i które na ostatnim XIX Zjeździe KPCh zadeklarowało kontynuację budowy „xiaokang shehui” (umiarkowanie zamożnego społeczeństwa) we wszystkich jego aspektach do 2021 r., a następnie w pełni rozwiniętego społeczeństwa socjalistycznego do $2049 \mathrm{r}$.

83 Zob. Deng Xiaoping, Wyzwalać myślenie, poszukiwać prawdy w faktach, jednoczyć się w patrzeniu w przyszłość. Przemówienie wygłoszone na końcowej sesji centralnej konferencji roboczej przed III Plenum KC 13 grudnia 1978 roku, [w:] Deng Xiaoping, Chińska droga do socjalizmu. Wybór prac z lat 1956-1987, Warszawa 1988, s. 81 i n. 
Oczywiście pierwsi chińscy marksiści i komuniści byli obznajomieni z pojęciem i koncepcją „datong”, czyli „wielkiego kursu", którą lubił się posługiwać się Sun Yatsen, nazywany ojcem odrodzonego narodu chińskiego, założyciel republiki chińskiej i jej pierwszy prezydent. Z tych powodów był on i nadal jest wielkim autorytetem historycznym dla KPCh, a jego małżonka była jedną ze współtwórczyń Chińskiej Republiki Ludowej. Kategoria i program „Datong” były także przedmiotem analizy historycznej znanego w latach 30. XX w. chińskiego filozofa Kang Youwei'a, który napisał na ten temat książkę opublikowaną w 1935 r. i które ponownie stały się aktualne wraz z wykorzystaniem tej idei przez reformatorów komunistycznych, którzy na bazie „socjalistycznej gospodarki rynkowej" lansowali od 1984 r. główne myśli tej książki, przedstawianej obecnie pod tytułem Datong shu.

$\mathrm{Na}$ uwagę zasługuje, że podczas trzeciego posiedzenia KC KPCh w lutym 2018 r. i pierwszej sesji KC Chin Ludowo-Politycznej Konferencji Konsultacyjnej Przewodniczący ChRL i jednocześnie sekretarz generalny KC KPCh Xi Jinping potwierdził także tworzenie „Xiaokang shehui” (umiarkowanej pomyślności, dobrobytu) do 2021 r., a w pełni nowoczesnego socjalistycznego społeczeństwa do 2049 r., co przyjęte zostało później przez Ogólnochińskie Zgromadzenie Przedstawicieli Ludowych jako program państwa. W związku z tym przywódca Chin zwrócił się do chińskich uczonych, w szczególności filozofów, o podjęcie pracy nad dalszym rozwojem i propagowaniem marksizmu. W następstwie powstają liczne nowe szkoły i kierunki badań i kształcenia marksizmu, w szczególności na uniwersytetach, a także innych szkołach wyższych, co stawia na wyższym poziomie rozwój teorii i metodologii marksistowskiej oraz ich nauczania wśród młodzieży akademickiej i w całym systemie edukacji. Zwrócono się także do dziennikarzy, by w swych artykułach bardziej posługiwali 
się językiem marksistowskim. Warto także przypomnieć, że w związku z 200-leciem urodzin Karola Marksa 5 maja 2018 r. ukazały się w Chinach liczne wznowienia prac Marksa i innych klasyków, były organizowane okolicznościowe konferencje, opublikowano wiele artykułów o nim i marksizmie, w których podkreślano aktualność myśli Marksa, jego krytyki kapitalizmu i alternatywy ustrojowej w postaci socjalizmu ${ }^{84}$.

Jednocześnie chińscy politycy i marksiści nieustannie podkreślają, że idą własną oryginalną drogą, nie kopiują żadnego innego modelu, budują „socjalizm z chińską specyfiką”. Nie mogło być inaczej, wzory czerpane z Europy Zachodniej, Rosji i Związku Radzieckiego czy innych dalekich państw mogły być wykorzystane tylko częściowo, bardziej jako teoria i metodologia niż konkretne formy, instytucje i metody procesu rewolucyjnego, walki o władzę, a później budowy podstaw socjalizmu. Chińskie społeczeństwo od tysięcy lat rozwijało się w oparciu o własne doświadczenie, kulturę i odrębności cywilizacyjne, kiedyś znacznie przodowało technologicznie i gospodarczo nad innymi państwami i cywilizacjami, co wytworzyło w szczególności wśród mandarynów poczucie wyższości a nawet pogardy dla „barbarzyńców”. System społeczny był skostniały, a bariery między ludem a "szlachetnie urodzonymi” praktycznie nieprzekraczalne. Decydował przyrodzony i dziedziczny status społeczny, majątkowy i rodzinny, umacniany autorytetem konfucjanizmu. Na przełomie XIX/XX w. Chiny były zacofaną despotycznie rządzoną monarchią, w której 90\% mieszkańców trudniła się rolnictwem i w większości była analfabetami. Wobec braku przemysłu i własnej klasy robotniczej na niewiele przydawały się analizy o rosnącej sile angielskiego czy w ogóle zachodniego proletariatu. Chiński lud pracujący

84 Por. Li Junru, What Do You Know About the Communist Party of China, Beijing 2018, s. 2 i n. 
oczekiwał czegoś innego niż powtarzania formułek z dalekiego świata. Chińscy postępowcy pojmowali to z trudem, ciągle byli spętani mitami o wyższości chińskiego sposobu życia i chińskiej cywilizacji. Z trudem torowała sobie drogę myśl, że we współczesnej epoce powstały potężne nowe siły wytwórcze, głównie przemysł, że światem rządzi wielka międzynarodowa finansjera a imperializm nie liczy się z żadnymi starymi wartościami i dąży do podporządkowania sobie wielkich obszarów kolonialnych. Chińscy marksiści i komuniści byli świadomi, że nie działają w kulturowej próżni, świadomość mas spętana była od wieków „prawdami”, wartościami i zasadami konfucjanizmu, a także innych religii, żeby więc pozyskać lud, głównie chłopów, musieli sięgać do argumentacji czerpiącej z konfucjanizmu. Najbardziej konsekwentny w tym zakresie był Mao Zedong, który opanował sofistykę konfucjańską dla odkrywania prawdy o ciężkiej doli chińskiego ludu, a jednocześnie pobudzać w nim chęć do buntu i walki o lepszą przyszłość. To przenikanie się marksizmu i konfucjanizmu nieustannie towarzyszyło procesowi rewolucyjnemu w Chinach i w zależności od napięcia walki klasowej miało charakter pokojowej konfrontacji bądź całkowitej negacji i administracyjnego zwalczania. Szczególnie ostra konfrontacja między marksizmem a konfucjanizmem miała miejsce w pierwszych latach ustanawiania władzy ludowej, która konsekwentnie usuwała pozostałości struktur, instytucji i myślenia postfeudalnego, antydemokratycznego, prokapitalistycznego i konfucjańskiego, nasiliła się także w okresie „wielkiej rewolucji proletariackiej”85.

Zjawiska te obecnie należą do przeszłości, filozofia Konfucjusza nie jest prześladowana, a nawet niektóre jej kategorie

85 Pewne aspekty tych zagadnień podejmuje Zhang Weiwei, A new Equilibrium Of Power. The CPC's strong leadership is key to China's success, „Beijing Review”, 19.10.2017, nr 42, s. 13-15, w szczególności znaczenia XIX Zjazdu KPCh. 
są wykorzystywane dla umocnienia pozycji KPCh, a także budowy społeczeństwa socjalistycznego. Jest to pewna sprzeczność, w związku z tym bardziej należy mówić o częściowym wykorzystaniu niektórych zasad, kategorii myśli Konfucjusza. Wychodząc naprzeciw oczekiwaniom kierownictwa politycznego zainicjowana została nie tylko na chińskich uniwersytetach kampania ponownego studiowania tekstów Konfucjusza w szczególności o „datong”, czyli „wielkim kursie” oraz porównywanie ich z wypowiedziami Marksa o komunizmie jako pozostających w związku przedmiotowym. Znawcy zagadnienia nawiązują m.in. do Księgi Liji (Księgi obyczajów) Konfucjusza, w szczególności jej rozdziału zatytułowanego „Li Yun”, w którym przedstawiona jest scena jak Konfucjusz obserwował obrzędy małego państwa w okresie dynastii Wiosen i Jesieni oraz Walczących Królestw (Wschodnich Zhou). Jeden z jego uczniów zauważył niepokój Mistrza i spytał o przyczynę. Ten mu odpowiedział, że żałuje, że nie będzie żył w epoce „datong” („wielkiego kursu”), który kiedyś miał miejsce i tak go opisał:

„Kiedy nastaje doskonały porządek [datong - przyp. Z.W.] świat jest jak dom, wspólny dla wszystkich. Na publiczne urzędy powoływani są cnotliwi i wartościowi ludzie, a intratne stanowiska piastują ludzie zdolni; życiowymi dewizami są zaufanie i pokój między wszystkimi ludźmi. Wszyscy ludzie kochają i szanują swoich rodziców i dzieci, jak też dzieci i rodziców innych ludzi. Dla starych jest opieka i troska, dla dojrzałych praca, dla dzieci wyżywienie i edukacja. Są środki na pomoc dla wdów i wdowców, dla każdego, kto czuje się samotny na świecie i dla niepełnosprawnych. Każdy mężczyzna i każda kobieta mają odpowiednie role do odegrania w rodzinie i społeczeństwie. Poczucie wspólnoty zajmuje miejsce egoizmu i materializmu. Oddanie publicznej służbie nie pozostawia miejsca próżniactwu. Intrygi, pobłażanie dla nieuczciwego bogacenia się są nieznane. Złoczyńcy, tacy jak złodzieje i rabusie, nie ist- 
nieją. Drzwi do każdego domu nie trzeba zamykać czy ryglować, ani w dzień, ani w nocy. Oto opis idealnego świata: stanu wspólnoty" (datong) ${ }^{86}$.

Owi mityczni ludzie nie przywiązywali wagi do własności, wszystko należało do wszystkich i chętnie dzielono się wytworzonymi bądź znalezionymi przedmiotami, wszyscy zdolni do pracy oddawali się zajęciom z całą siłą, wszyscy czuli się potrzebni i byli potrzebni. Oto obraz społeczeństwa określanego przez Konfucjusza jako „datong”, tłumaczonego także jako „wielka jedność”. Z zamieszczonego tekstu przebija tęsknota Konfucjusza za mitycznym „złotym wiekiem”, pierwszymi legendarnymi dynastiami Xia (XXI-XVI w. p.n.e.), dynastią Shang XVI-XI w. p.n.e. i dynastią Zachodnich Zhou (XI w. p.n.e-770 r. p.n.e), które organizowały państwa chińskie w oparciu o jeszcze słabo wykształcone różnice klasowe i zachowane, nie do końca przezwyciężone stosunki i instytucje społeczeństwa wspólnoty pierwotnej. Najbardziej zakonserwowanym środowiskiem tego rodzaju stosunków były, o czym już wspomniano, wspólnoty wiejskie (gminne), których pewne podobne elementy przetrwały także w innych kręgach kulturowych. Także w Polsce, szczególnie w zasiedziałych środowiskach wiejskich w tzw. zapadłych rejonach kraju, znane było poczucie powszechnego bezpieczeństwa mieszkańców, panowało powszechne zaufanie, nie obawiano się złodzieja, a klucz pozostawiany był w zamku drzwi lub chowano go pod wycieraczką, ale czy jest to istotna cecha stosunków definiowanych jako komunistyczne, rzecz bardzo wątpliwa. Najbardziej znamienny dla tego opisu jest brak prywatnej własności środków produkcji i państwa jako instytucji heterogenicznej, przymusowej i mającej prawo stosowania legalnego przymusu przez odrębny typ organizacji społecznej, wyposażonej w samorodną

86 Konfucjusz, Dialogi - Lun Yu, cz. 1, Kielce 2008, s. 611. 
władzę. Jest to w gruncie rzeczy tęsknota za społeczeństwem sprawiedliwym, może także równościowym, choć w wielu innych miejscach Konfucjusz wyraża aprobatę dla społeczeństwa klasowego, zorganizowanego hierarchicznie, w którym jest zasada: „Niechaj panowie będą panami, poddani poddanymi, ojcowie ojcami, synowie synami”. W innym miejscu Konfucjusz podkreślał, że „wszystko pod słońcem dzieje się zgodnie z wolą niebios..." 87 .

Zdaniem Mahoney'a podobnie Marks odwoływał się do przedmiotu i cech komunizmu we wczesnym okresie swoich badań nad rozwojem społeczeństwa. Uważa on, że są w nich zbliżone do „datong” cechy i treści. Marksowskie wyobrażenie o komunizmie znalazło głównie wyraz we wczesnym okresie jego twórczości i przez wiele lat nie były one publikowane. Analizy Marksa były wyrazem badań teoretycznych, jak i wyrastały z potrzeb nasilającej się krytyki szybko rozwijającego się w poł. XIX stulecia kapitalizmu i ruchu robotniczego. Przede wszystkim była to krytyka utopijnych poglądów socjalistów utopijnych, np. Saint Simona, Owena, a także tzw. socjalistów drobnomieszczańskich, np. Proudhona czy też innych przedstawicieli różnych kierunków tzw. socjalizmu burżuazyjnego czy religijnego. Badania te prowadzone były przez Marksa (także Engelsa) w oparciu o teorię i metodologię materializmu dialektycznego i historycznego, którzy w rozwoju sił wytwórczych i ich sprzecznościach dostrzegali istotę przeciwieństw, przemian społecznych, ustrojowych i kształtowanie się stosunków klasowych, które w okresie formacji kapitalistycznej doprowadziły do przeciwieństwa między burżuazją a proletariatem. Wielką zasługą Marksa było, że w proletariacie dostrzegł on klasę społeczną, która nie tylko poprzez pracę czerpie środki niezbędne dla własnej egzystencji, ale

87 Konfucjusz, Dialogi..., op.cit., s. 355, 510. 
przekształcając się z klasy w sobie w klasę dla siebie, organizuje się, umacnia w celu rewolucyjnego obalenia panowania kapitalizmu i wprowadzenia ustroju komunistycznego, który znosi własność prywatną środków produkcji, likwiduje wyzysk człowieka przez człowieka i tworzy społeczeństwo bez antagonizmów klasowych, ustanawia własność społeczną. Marks uważał, że zmiany ustroju klasowego społeczeństwa nie można przeprowadzić w oparciu o założenia idealistycznej filozofii, w tym wyrażała się jego krytyka ówczesnych teorii socjalizmu utopijnego, ponieważ zwierały one podstawowy błąd, który determinował tak rozumiany socjalizm jako efekt dobroczynnej działalności jednostek, a nie jako efekt sprzeczności społecznych, które tworzyły warunki dla istnienia i pogłębiania się wyzysku oraz nierówności społecznych. W późniejszych swych pracach Marks pogłębił badania nad istotą komunizmu i bardziej rozwinął je w Rękopisach ekonomiczno-filozoficznych a w szczególności w Manifeście komunistycznym z 1848 r., napisanym wraz z F. Engelsem.

Na uwagę zasługuje jedno z pierwszych stwierdzeń Marksa o komunizmie, zawarte w Rękopisach ekonomiczno-filozoficznych z 1844 r.: „Komunizm jako pozytywne zniesienie własności prywatnej - tej samoalienacji człowieka i dlatego też jako rzeczywiste przyswojenie ludzkiej istoty przez człowieka i dla człowieka; dlatego też jako pełny powrót człowieka do samego siebie jako do człowieka społecznego, to znaczy ludzkiego, powrót dokonany świadomie i w oparciu o całe bogactwo dotychczasowego rozwoju. Komunizm ten jako skończony naturalizm = humanizmowi, jako skończony humanizm = jest naturalizmowi: stanowi on prawdziwe rozwiązanie konfliktu między człowiekiem a przyrodą oraz między człowiekiem a człowiekiem, prawdziwe rozwiązanie konfliktu między istnieniem a istotą, między uprzedmiotowieniem a samostanowieniem, między wolnością a koniecznością, między osobni- 
kiem a gatunkiem. Stanowi on rozwiązanie zagadki historii i jest świadomy tego" 88 .

Na marginesie tego obszernego cytatu z Marksa dodajmy, że autor przedstawił wcześniej etapy rozwoju myśli komunistycznej, nawiązywał do komunizmu prymitywnego, utopijnego, traktując je jako żywiołową negację zniewolonego człowieka, którego system własności prywatnej uczynił w sensie prawnym bądź ekonomicznym. „Komunizm jest pozytywnym wyrazem zniesienia własności prywatnej: początkowo występuje on jako powszechna własność prywatna". Ten etap rozwoju nazywał on komunizmem prymitywnym. Drugi etap rozwoju komunizmu widział on jako taki stopień rozwoju społeczeństwa, który a) jest „jeszcze o charakterze politycznym, demokratycznym lub despotycznym” i b) „połączony ze zniesieniem państwa, ale zarazem jeszcze nie w pełni rozwinięty i w dalszym ciągu pozostający pod wpływem własności prywatnej, czyli alienacji człowieka..." ${ }^{\prime 9}$.

Karol Marks widział więc przede wszystkim w zniesieniu własności prywatnej główną przesłankę powstania komunizmu jako ustroju, który nie tylko znosi własność prywatną jako podstawę wyzysku i nierówności, ale także alienacji człowieka. Tym się różni od wcześniejszych postaci komunizmu i jednocześnie stawiał go na podstawie naukowej, wskazując siłę klasowo-społeczną, która jest w stanie dokonać rewolucyjnych zmian i wprowadzić komunizm naukowy - proletariat. Tę naukową wizję rozwoju historycznego przedstawił z Engelsem kilka lat później w Manifeście komunistycznym.

Poglądy klasyków na temat komunizmu kształtowały się w toku ostrej walki ideowo-politycznej między różnymi siłami społecznymi i towarzyszącymi im naiwnymi bądź reakcyjnymi

88 K. Marks, Rękopisy ekonomiczno-filozoficzne z 1844 r., [w:] K. Marks, F. Engels, Dzieła. t. 1, Warszawa 1976, s. 577.

89 Ibidem. 
koncepcjami socjalizmu. Do urzeczywistnienia idei socjalizmu nie wystarczają same idee, potrzebni są ludzie uzbrojeni w naukową teorię socjalizmu, klasa robotnicza, która obiektywnie jest zainteresowana w obaleniu starego burżuazyjnego ustroju i wprowadzeniu komunizmu. Ten kierunek myślenia wspierały prace Engelsa pt. Potożenie klasy robotniczej w Anglii, Rozwój socjalizmu od utopii do nauki, i inne, a także wspólne prace, takie jak Święta rodzina, czyli krytyka krytyczna krytyki. Przeciwko Brunonowi Bauerowi i spótce ${ }^{90}$ czy późniejsza praca pt. Ideologia niemiecka. Krytyka najnowszej filozofii niemieckiej w osobach jej przedstawicieli Feuerbacha, B. Bauera i Stirnera, tudzież niemieckiego socjalizmu w osobach różnych jego proroków ${ }^{91}$.

W szczególności w tej ostatniej pracy przeprowadzili oni gruntowną krytykę stosunków własnościowych, ekonomicznych, społecznych i politycznych społeczeństwa od niewolnictwa do szybko rozwijającego się w latach 40. XIX w. kapitalizmu, odnieśli się także do perspektywy rozwoju społeczeństwa, określanego przez sprzeczności między burżuazją a proletariatem, wskazując na możliwość jej rozwiązania przez rewolucję społeczną i powstanie społeczeństwa komunistycznego. W związku z tym poddali krytyce dotychczasowe poglądy socjalizmu utopijnego i drobnomieszczańskiego, przedstawionych głównie w publikacjach autorów niemieckich tego okresu, opierając się także na doświadczeniach rozwoju kapitalizmu w Anglii, Francji i Ameryce. Pozwoliło to im wysunąć hipotezy na temat przyszłego rozwoju przesłanek rewolucji, zdobycia władzy państwowej przez proletariat i budowy

90 F. Engels, K. Marks, Święta rodzina, czyli krytyka krytycznej krytyki. Przeciwko Brunonowi Bauerowi i spótce, [w:] K. Marks, F. Engels, Dzieła, t. 2, Warszawa 1979, s. 3 i n.

91 K. Marks, F. Engels, Ideologia niemiecka. Krytyka najnowszej filozofii niemieckiej w osobach jej przedstawicieli Feuerbacha, B. Bauera i Stirnera, tudzież niemieckiego socjalizmu w osobach różnych jego proroków, [w:] K. Marks, F. Engels, Dzieła, t. 3, Warszawa 1975, s. 9 i n. 
komunizmu. Stwierdzili, że „każda dążąca do władzy klasa choćby nawet jej panowanie warunkowało, jak to ma miejsce z proletariatem zniesienie całej dawnej formy społeczeństwa i w ogóle panowania - musi najpierw zdobyć władzę polityczną, aby z kolei przedstawić swój interes jako coś ogólnego" ${ }^{\prime 2}$.

Dalej zdaniem klasyków samo zdobycie władzy nie jest wystarczające, proletariat musi także w następnej kolejności przezwyciężyć i znieść alienację, czyli proces wyobcowania, w którym wytwory społecznego współdziałania ludzi zaczynają się wyodrębniać od swych wytwórców i przeciwstawiać się im jako samodzielna rzeczywistość, niepoddająca się kontroli człowieka. Oznacza to, że ta alienacja „może być zniesiona tylko przy dwóch praktycznych przesłankach. Musi stać się »siłą nie do wytrzymania «tzn. siłą przeciw której robi się rewolucję, musi uczynić wielką masę ludzkości zupełnie »bezwłasnościową « i stojącą jednocześnie w sprzeczności z istniejącym światem bogactwa i wykształcenia, a jedno i drugie ma za przesłankę olbrzymi wzrost siły wytwórczej, wysoki stopień jej rozwoju. Z drugiej strony ten rozwój sił wytwórczych (co zakłada empiryczne urzeczywistnienie powszechno-dziejowej, nie zaś tylko lokalnej działalności życiowej ludzi) jeszcze dlatego stanowi absolutnie konieczną przesłankę praktyczną, że bez niego musiałby się stać powszechnym tylko niedostatek, a wraz z nędzq musiałaby się znów rozpocząć walka o rzeczy nieodzowne i wrócić by musiało całe dawne paskudztwo; następnie dlatego że tylko na uniwersalnym rozwoju sił wytwórczych zasadzają się uniwersalne stosunki ludzi ze sobą, stąd $\mathrm{z}$ jednej strony wrodzona we wszystkich narodach jednocześnie (powszechna konkurencja) zjawisko »bezwłasnościowej« masy czyni każdy z tych narodów zależnym od przewrotów

92 Ibidem, s. 36. Na temat etapów kształtowania się myśli o naukowym komunizmie zob. Z.B. Wiktor, Geneza i rozwój teorii naukowego komunizmu, Wrocław 1986, s. 11 i n. 
w innych; wreszcie rozwój ten sprawia, że na miejsce jednostek lokalnych przychodzą jednostki powszechno-dziejowe, empirycznie uniwersalne" ${ }^{\prime 93}$.

W dalszej części Marks i Engels dowodzili, odchodząc od rozważań czysto teoretycznych i hipotetycznych, że „Komunizm jest empirycznie możliwy tylko jako czyn narodów panujących dokonany »za jednym zamachem «i równocześnie (»auf einmal oder gleichzeitig«), co zakłada uniwersalny rozwój sił wytwórczych i związanych z tym stosunków między ludźmi w skali światowej. (...) Zresztą istnienie masy ludzkiej żyjącej tylko ze swojej pracy - masy siły roboczej, odciętej od kapitału albo od możliwości chociażby ograniczonego zaspokojenia swych potrzeb i charakteryzującej się stąd możliwością już nie tylko czasowej utraty samej pracy jako źródła egzystencji - zakłada z góry, z racji konkurencji, istnienie rynku światowego. Proletariat może więc egzystować tylko w sensie światowo-dziejowym, podobnie jak będący jego dziełem komunizm możliwy jest w ogóle tylko jako egzystencja o światowo-dziejowym charakterze. A egzystencja jednostek o charakterze światowo-dziejowym - to egzystencja związana bezpośrednio z dziejami świata" ${ }^{94}$.

Pod koniec lat 40. XIX w. Marks i Engels zbliżyli się do precyzyjnego teoretycznego określenia miejsca formacji komunistycznej w historii społeczeństwa, traktują ją jako finalny rezultat rozwoju sił wytwórczych i towarzyszących im sprzeczności i walk klasowych. W najwcześniejszym okresie ludzkości panowała bezklasowa wspólnota pierwotna, którą zastąpiło niewolnictwo, następnie feudalizm, kapitalizm. Ale kapitalizm nie jest ostatnim słowem historii. „Miejsce dawnego społeczeństwa burżuazyjnego z jego klasami i przeciwieństwami klasowymi zajmuje zrzeszenie, w którym swobodny rozwój każdego jest

\footnotetext{
93 K. Marks, F. Engels, Ideologia niemiecka..., op.cit., s. 37.

94 Ibidem, s. 38.
} 
warunkiem swobodnego rozwoju wszystkich" ${ }^{\text {95 }}$. Historycznym dążeniem proletariatu jest rewolucja socjalistyczna, która prowadzi proletariat do wydźwignięcia go „do stanowiska klasy panującej, wywalczenia demokracji" ${ }^{96}$. Ale proletariat zdobędzie władze nie tylko po to, by odsunąć burżuazję od panowania. „Proletariat użyje swego panowania politycznego na to, by krok za krokiem wyrwać z rąk burżuazji cały kapitał, scentralizować wszystkie narzędzia produkcji w ręku państwa, tzn. w ręku zorganizowanego jako klasa panująca proletariatu, i możliwie szybko zwiększyć masę sił wytwórczych"97. W dalszej kolejności klasycy wysunęli bardziej sprecyzowane zmiany i posunięcia, które były niezbędne dla ostatecznego odsunięcia burżuazji od polityki i gospodarki oraz ustanowienia panowania politycznego, ekonomicznego i ideologicznego proletariatu: „Ten okres przejściowy, rewolucyjny przybiera w krajach najbardziej zaawansowanych następujące posunięcia: 1 . Wywłaszczenie własności ziemskiej i renty gruntowej na wydatki państwowe; 2. Wysoka progresja podatkowa; 3. Zniesienie prawa dziedziczenia; 4. Konfiskata własności wszystkich emigrantów i buntowników; 5. Scentralizowanie kredytu w rękach państwa poprzez bank narodowy o kapitale państwowym i o wyłącznym monopolu; 6. Scentralizowanie środków transportu w rękach państwa; 7. Zwiększenie liczby fabryk państwowych, narzędzi produkcji, udostępnienie gruntów do uprawy i ich melioracji według społecznego planu; 8. Jednaki przymus pracy dla wszystkich, utworzenie armii przemysłowych, zwłaszcza dla rolnictwa; 9. Zespolenie rolnictwa i przemysłu, działanie w kierunku stopniowego usunięcia przeciwieństwa między miastem a wsią; 10. Publiczne i bezpłatne wychowanie wszystkich dzieci. Zniesienie pracy fa-

95 K. Marks, F. Engels, Manifest komunistyczny, [w:] K. Marks, F. Engels, Dzieła, t. 4, Warszawa 1962, s. 536.

96 Ibidem.

97 Ibidem, s. 535. 
brycznej dzieci w jej dzisiejszej postaci. Połączenie wychowania z produkcją materialną itd." ${ }^{\prime 9}$.

Te założenia sprawdziły się tylko częściowo. Kwestia rewolucyjnego jednoczesnego przejścia od kapitalizmu do socjalizmu oparta była na sprzecznościach i nierównościach ówczesnego kapitalizmu, który miał liberalny charakter i nawet w najbardziej rozwiniętych państwach nie było jeszcze tak jak dziś rozbudowanego aparatu przymusu. Klasykom wydawało się, że rewolucja proletariacka wybuchnie w najbardziej rozwiniętych państwach, np. w Anglii, która władała olbrzymim imperium kolonialnym, także w innych państwach kolonialnych, także w USA, które stały jeszcze przed okresem budowania swej potęgi światowej. Inne państwa się nie liczyły i ułatwiało to klasykom stawianie hipotez par excellence teoretycznych. Tak zarysowanej perspektywy rozwoju nie potwierdził dalszy rozwój kapitalizmu, który szybko przechodził w stadium dalszej ekspansji kolonialnej i imperialistycznej. Jednocześnie burżuazja liberalna wchodziła $\mathrm{w}$ alianse $\mathrm{z}$ innymi reakcyjnymi klasami, np. we Francji, a w szczególności w Niemczech jednocześnie ograniczała prawa nie tylko socjalne, także polityczne dla upośledzonych niższych klas, szczególnie proletariatu. Na tym tle rozwijał się ruch robotniczy, szczególnie socjaldemokratyczny, który uzyskiwał coraz większe poparcie ze strony nie tylko fabrycznego proletariatu, także innych wyzyskiwanych warstw społecznych. Tworzyła się nowa sytuacja polityczno-ustrojowa, mianowicie możliwość zdobycia władzy drogą parlamentarną. Z czasem ta droga stała się dominująca w programach kierownictwach partii socjaldemokratycznych, negujących rewolucyjne przejście do socjalizmu i dyktaturę proletariatu i wysuwając jako główne hasło walki o władzę drogę parlamentarną i tzw. demokratyczny socjalizm. W grun-

98 Ibidem, s. 535-536. 
cie rzeczy było to odejście od oryginalnego, rewolucyjnego marksizmu i zejście socjaldemokracji na pozycje oportunizmu i prawicowego reformizmu, wykorzystanego przez burżuazję do walki z rewolucyjnym ruchem robotniczym ${ }^{99}$.

W marcu-maju 1871 r. w Paryżu wybuchło powstanie francuskiego proletariatu, które zakończyło się zwycięstwem ludu Paryża i ustanowieniem na dwa miesiące Komuny Paryskiej, czyli pierwszego państwa socjalistycznego. Było ono potwierdzeniem tezy klasyków o możliwości zdobycia władzy przez proletariat, jednocześnie wykazało cały szereg słabości teoretycznych dotychczasowego rozwoju marksizmu, jak i możliwości ideowo-politycznych i organizacyjno-wojskowych państwa burżuazyjnego, szczególnie francuskiego, które krwawo rozprawiło się z komunardami, korzystając także z pomocy okupantów pruskich. Ujawniły się liczne słabości i braki teoretyczne kierownictwa Komuny, podziały ideowo-polityczne w jej kierownictwie, brak poparcia ze strony innych francuskich ośrodków robotniczych, brak zaufania do chłopstwa, które uważane było za klasę reakcyjną i w związku z tym niemożliwość utworzenia jednolitego antykapitalistycznego frontu narodowego. Wykorzystały to ośrodki burżuazyjne, przeciągając chłopstwo na swoją stronę. Komuna Paryska nie uzyskała także szerokiego rewolucyjnego poparcia ze strony międzynarodowego proletariatu. W tej sytuacji nie mogła się utrzymać i po dwóch miesiącach bohaterskiej walki została krwawo stłumiona przez wojska burżuazyjnej republiki.

Okres lat 1871-1914 był brzemienny dla dalszego szybkiego rozwoju kapitalizmu, który przekształcił się w stadium imperialistyczne. Następowała dalszy rozwój i koncentracja finansów i przemysłu, na czoło wysunęły się państwa imperialistyczne

99 Szerzej na ten temat zob. D. Priestland, Welt - Geschichte des Kommunismus. Von der Franzoesischen Revolution bis heute, Muenchen 2009, s. $51 \mathrm{i} \mathrm{n.}$ 
jak Anglia, Francja, Niemcy, USA, Rosja, Turcja, a na Dalekim Wschodzie Japonia. Trwała między nimi ostra walka o ostateczny podział kolonii, jednocześnie były one włączane w zależności gospodarki kapitalistycznej poprzez masowy wywóz kapitału finansowego i wzrost wyzysku nie tylko własnego proletariatu, także uzależnionych obszarów kolonialnych. Świat wkraczał w dobę globalnych procesów gospodarczych i światowej rywalizacji mocarstw o nowy podział świata. Narastały sprzeczności wojenne, które rezultowały licznymi wojnami lokalnymi, a w1914 r. wybuchła wielka wojna światowa. W tym czasie rozwinął się w wielu państwach europejskich silny ruch robotniczy, który poczynając od 1864 r. zjednoczył się w Międzynarodowe Stowarzyszenie Robotników - I Międzynarodówkę, która trwała do 1876 r. W 1889 r. powstała II Międzynarodówka, która faktycznie trwała do 1914 r. i w rzeczywistości rozpadła się na skutek wybuchu wojny i głębokich różnic w jej kierownictwie, które udzieliły w większości poparcia dla kredytów wojennych dla swych rządów i faktycznie dla imperialistycznej wojny ${ }^{100}$.

W schyłkowym okresie działalności II Międzynarodówki dużą rolę odegrała Rosyjska Socjaldemokracja, na czele z Włodzimierzem I. Leninem, który wychodząc z analizy kapitalizmu imperialistycznego wysunął twierdzenie o możliwości obalenia kapitalizmu i przeprowadzenia rewolucji socjalistycznej w Rosji jako kraju o słabym rozwoju kapitalizmu i z licznymi pozostałościami reakcyjnego feudalizmu, jednak z licznymi skupiskami proletariatu w wielkich zakładach przemysłowych, co było pozytywną przesłanką przerwania słabego ogniwa w łańcuchu państw kapitalistycznych. Rewolucja w Rosji miała być początkiem „światowej rewolucji”, do której na skutek wielkiego spiętrzenia sprzeczności dołączą inne rewolucje i państwa, otwierając drogę do obalenia kapitalizmu i zwycięstwo socjali-

100 Ł.I. Zubok (red.), Historia Drugiej Międzynarodówki, t. 1, Warszawa 1978, w szczególności s. 157 i n. oraz t. 2, s. 501 i n. 
zmu w skali światowej. Lenin był marksistą, który rozwinął jego podstawowe tezy odpowiednio do nowej epoki, jej sprzeczności gospodarczych i politycznych w dobie imperializmu. Jednocześnie wskazał na istotną rolę nowych oddziałów proletariatu w państwach słabo rozwiniętego kapitalizmu, w których jednak ze względu na wielkie sploty sprzeczności powstawały przesłanki sytuacji rewolucyjnej. Dotyczyło to nie tylko Rosji i jej olbrzymiego terytorium, ale także innych państw Europy Środkowo-Wschodniej, a przede wszystkim państw kolonialnych i zależnych, takich jak Chiny, Indie i wielu innych.

Potwierdzeniem tych twierdzeń i prognoz rozwojowych procesu rewolucyjnego była rewolucja październikowa w 1917 r. w Rosji, która obaliła reżim burżuazyjno-obszarniczy i ustanowiła powstanie Rosyjskiej Socjalistycznej Federacyjnej Republiki Radzieckiej, a od 1922 r. Związku Socjalistycznych Republik Radzieckich. Było to pierwsze po Komunie Paryskiej państwo socjalistyczne, które na ponad siedemdziesiąt lat wprowadzało stosunki i instytucje socjalistyczne, które przeorało świadomość ideowo-polityczną ludu rosyjskiego i wywarło olbrzymi wpływ na zmiany ideowo-polityczne współczesnego świata. Przede wszystkim potwierdzona została teza klasyków marksizmu, że proletariat może zdobyć władzę państwową i sprawować ją z ludem, przez lud i dla ludu, uświadomiła ludom państw kolonialnych i półkolonialnych, że rewolucję można także przeprowadzić we własnych krajach, że można zrzucić jarzmo kolonialne i wyzwolić się od panowania własnych panów feudalnych i kapitału zagranicznego. Przed licznymi narodami kolonialnymi i półkolonialnymi stanęła otworem walka o wyzwolenie narodowe i społeczne ${ }^{101}$.

Szczególnie było to ważne dla wielkiego narodu chińskiego, który od prawie 100 lat pozostawał w pogłębiającej się zależ-

101 Por. J. Muszyński, Teoria przechodzenie od kapitalizmu do komunizmu, [w:] Teoria naukowego komunizmu, red. idem, Warszawa 1979, s. 182 i n. 
ności od Anglii, Francji, Rosji, Niemiec i Japonii. Na początku XX w. do Chin trafiły pierwsze idee marksistowskie, które obejmowały coraz większe kręgi demokratycznej młodzieży, także proletariackiej. Wielką rolę budzeniu świadomości narodowej odegrały wydarzenia 4 Maja 1919 r. w Pekinie, które pobudziły demokratycznie nastrojoną młodzież chińską a od lipca 1921 r. powstanie Komunistycznej Partii Chin w Szanghaju, które były iskrą, od której w następnych latach postępy rewolucji zaczęły zmieniać Chiny. W październiku 1949 r. powstała Chińska Republika Ludowa, która przechodząc przez liczne etapy swego rozwoju w ciągu siedemdziesięciu lat rozwinęła się jako wielkie socjalistyczne mocarstwo, które dzięki socjalistycznej gospodarce rynkowej wysunęły Chiny na drugą pozycję w świecie pod względem wielkości PKB. Stawia to kwestię socjalizmu jako aktualne zagadnienie rozwojowe w państwach o słabszym poziomie rozwoju sił wytwórczych, głównie przemysłu. Nowym oryginalnym elementem teorii marksizmu w Chinach było zwycięstwo proletariatu wiejskiego i swoiste otoczenie miast. Powstaje pytanie, czy nie jest to droga, a właściwie model teoretyczny, który może być powtórzony przez szereg innych krajów tzw. rozwijających się, zwanych też Państwami Trzeciego Świata, nie tylko w Azji, także w Afryce i Ameryce Łacińskiej ${ }^{102}$.

Jednocześnie w Chinach ważne miejsce w przemianach demokratycznych i socjalistycznych odgrywał nie tylko marksizm, ale także konfucjanizm. W pierwszych latach rewolucji konfucjanizm był zwalczany jak filozofia idealistyczna i powiązana z nią religia konfucjańska głównie z powodu reakcyjnej roli jaką pełniły jako podpora ideologiczna dawnego reżimu cesarskie-

102 Więcej na ten temat zob. wnikliwe studium uczonych chińskich z Uniwersytetu Wuhan pt. Studia o sinicyzacji historii marksizmu (Study on the Sinicization History of Marxism. Library of Marxism Studies, Wuhan 2015, s. 1-537, po chińsku. 
go. W czasach socjalistycznych przemian konfucjanizm utracił wiodące znaczenie w kształtowaniu świadomości i światopoglądu społeczeństwa chińskiego i decydujące znaczenie w kształtowaniu tego światopoglądu ma Komunistyczna Partia Chin w oparciu o marksizm-leninizm, rozwinięty i dostosowany do odrębności i specyfiki cywilizacyjno-kulturowe społeczeństwa chińskiego przez kolejne generacje chińskich przywódców i uczonych od Mao Zedonga do Xi Jinpinga. Wraz z wdrożeniem socjalistycznej gospodarki rynkowej, a w szczególności w jej ostatniej fazie kierownictwo KPCh dostrzega możliwość wykorzystania niektórych zasad, pojęć i wartości konfucjańskich dla umocnienia zwartości społeczno-kulturowej społeczeństwa w obliczu nowych wielkich wyzwań gospodarczych i międzynarodowych, przed którymi obecnie stoją Chiny ${ }^{103}$.

Podsumowując możemy stwierdzić, że filozofia Konfucjusza i jego uczniów miała wielki wpływ na rozwój kultury i cywilizacji chińskiej do XX w. Wraz z wejściem w orbitę wpływów cywilizacji zachodnich napłynęły do Chin liczne kierunki i szkoły myślenia, także filozoficzne z USA i państw Europy Zachodniej, głównie kapitalizm i towarzyszące mu teorie jak liberalizm, demokracja, prądy religijne, później naukowy socjalizm. W wyniku licznych przegranych batalii politycznych i wojennych traciły pozycję głównych ideologii rodzime teorie i koncepcje postrzegania i wyjaśniania świata w oparciu o rodzime nurty myślenia, w tym konfucjanizm. Proces ten następował powoli i stopniowo. Bardziej otwarte na trendy zachodnie pozostawały miasta i powstająca tam rodzima burżuazja oraz powstające nowe środowiska kapitalistyczno-prze-

103 Por. w szczególności Xi Jinping, Szecure a Decisive Victory in Building a Moderattely Prosperos Society in All Respects and Strive for the Great Success of Socialism with Chinese Characteristics for a New Era, Delivered at the $19^{\text {th }}$ National Congress of the Communist Party od China, 18.10.2017, http:/www.chinadaily.com.cn/china/19thcpcnationalcongess/2017-11/04/ content_34115212.htm. 
mysłowe i polityczne. Duży wpływ miały też strefy otwarte i koncesje, gdzie dominowały nie tylko obce kapitały (banki) i biali kolonizatorzy, ale także masy ludowe, wciągane w procesy ekonomiczno-produkcyjne.

Rewolucja socjalistyczna przyczyniła się zasadniczo do osłabienia i wyeliminowania z życia ideowo-politycznego konfucjanizmu jako wiodącej ideologii chińskiej, ale jednocześnie obecnie KPCh ze względów utylitarnych wykorzystuje niektóre jego tezy dla realizacji własnych celów, np. uzyskania większego poparcie dla silnego scentralizowanego państwa (z konfucjanizmu), wykorzystanie kategorii rządów prawa (z legizmu), wartości i kategorii harmonia społeczna (wielka jedność), a także niektórych wątków konfucjańskiego socjalizmu utopijnego. Kategorie konfucjańskie, takie jak wielki kurs, chińskie marzenie, chińska droga, chiński ład, społeczeństwo dostatku i inne zostały wprowadzone w pracach partyjno-ideowych przez obecnego przywódcę Xi Jinpinga. W ten sposób „chiński marksizm” i „chiński socjalizm” mocniej zakorzeniają się w dziejach i kulturze Chin. Stanowią także podstawę interesujących dyskusji teoretycznych o chińskiej drodze do socjalizmu i jej specyfice, wynikającej z odrębności rozwojowej chińskiej cywilizacji ${ }^{104}$.

\section{Bibliografia}

An Introduction to Chinese Classics: Cofucianism, Taoism and Buddhism, wydawcy: Li Ji, Wang Yueing, Beijing 2014. A Series of the Chinese Eco-System Constructors in China, Hefei 2013.

104 Więcej na temat chińskiej koncepcji budownictwa socjalistycznego w XXI wieku zob. Z. Wiktor, Chińska wizja budowy socjalizmu w świetle materiałów XIX Zjazdu KPCh, [w:] Wektory zmian w polityce Chińskiej Republiki Ludowej w okresie rządów Xi Jinpinga, red. J. Marszałek-Kawa, M. Bidziński, Toruń 2018, s. 27-137. 
Asian Governance Synergy, „Beijing Review”, 25.05.2019, nr 21. Bai Shouyi, Yang Zhao, Gong Shuduo, Wang Guilin, Lu Zhenxiang, Fang Linggui, Zhu Zhongyu, Guo Dajun, $A n$ Outline History of China, Beijing 2002.

Baranowska M., Cel uświęca środki, czyli Nicolo Macchiavellego rozważania o władzy, Toruń 2018.

Borgosz J., Próba filozoficznej analizy maoizmu, [w:] Chińska Republika Ludowa. Ideologia, polityka, gospodarka, oprac. J. Borgosz, E. Krawczyk, S. Łysko, J. Muszyński, J. Sokół, A. Żebrowski, Warszawa 1979.

Burłackij F., Mao Czedun, Moskva 2003.

Catalyst For Renewal. Dialogue between Asian civilisations pools wisdom for a better shared future, „Beijing Review”, 21.05.2019, nr 21.

China, Xinjiang, Facts and Figures in 60 Years 1955-2015, China International Press, China 2016.

Czarnik T., Starożytna filozofia chińska, Kraków 2001.

Deng Xiaoping, Chiny na drodze reform w XXI wieku, Toruń 2007.

Deng Xiaoping, Chińska droga do socjalizmu. Wybór prac z lat 1956-1987, Warszawa 1988.

Deng Xiaoping, Przestrzegać czterech podstawowych zasad, [w:] idem, Chińska droga do socjalizmu. Wybór prac z lat 1956-1987, Warszawa 1988.

Deng Xiaoping, Selected Works. Vol. III (1982-1992), Beijing 1994.

Deng Xiaoping, Wyzwalać myślenie, poszukiwać prawdy w faktach, jednoczyć się w patrzeniu w przyszłość. Przemówienie wygłoszone na końcowej sesji centralnej konferencji roboczej przed III Plenum KC 13 grudnia 1978 roku, [w:] Deng Xiaoping, Chińska droga do socjalizmu. Wybór prac z lat 1956-1987, Warszawa 1988. 
Dziak W.J., Bayer J., Mao Zedong (Mao Tse-tung). Zwycięstwa, nadzieje, klęski, Warszawa 2007.

Engels F., Karol M., Święta rodzina czyli krytyka krytycznej krytyki. Przeciwko Brunonowi Bauerowi i spółce, [w:] K. Marks, F. Engels, Dzieła, t. 2, Warszawa 1979.

Fenby J., Upadek i narodziny wielkiej potęgi, Kraków 2009.

Fei Xiaotang, Rural China, Shanghai 1948.

Feng Youlan, Krótka historia filozofii chińskiej, Warszawa 2001. Granet M., Cywilizacja chińska, Warszawa 1973.

Grzybowski K., Nicolo Macchiavelli, Ksiażę. Warszawa 1970. Historia Powszechna, t. 2, Warszawa 1964.

Holubnychy, Mao Tse-tung's Materialistic Dialectics, „The China Quarterly", lipiec-sierpień 1964, nr 19.

Jiang Changyan, China in Transition: Agriculture, Rural Areas and Farmers, Anhui 2014.

Konfucjusz, Dialogi - Lun Yu, cz. 1, Kielce 2008.

Konfucjanizm, [w:] Wielka encyklopedia powszechna PWN, t. 14, red. B. Suchodolski, Warszawa 2003.

Konfucjanizm, [w:] Wielka encyklopedia powszechna PWN, t. 5, red. B. Suchodolski, Warszawa 1963.

Kość A., Konfucjanizm, [w:] Powszechna encyklopedia filozofii, t. 5, red. A. Maryniarczyk Lublin 2004.

Kość A., Prawo a etyka konfucjańska w historii myśli prawnej Chin, Lublin 1998.

Li Junru, What Do You Know About The Communist Oarty of China, Beijing 2018.

Li Zhisui, Prywatne życie Przewodniczacego Mao, Warszawa 1996.

Lin Weida, Lin Xiangfeng (red.),, Chińskie $A B C$, Brzezia Łąka 2016.

Mahoney J.G., Marx and Confucius, The intersections between communism and datong, „Beijing Review”, 10.05.2018, nr 19. 
Ma Huali, Hu Yan, China's Urbanization, China 2013.

Mao Tse-Tung, Dzieła wybrane, t. 1, 2, 3, Warszawa 1953$-1954$.

Mao Tse-tung, Pozycja Komunistycznej Partii Chin w wojnie narodowej (październik 1938 roku), [w:] Mao Tse-Tung, Dzieła wybrane, t. 2, Warszawa 1954.

Mao Zedong, O demokratycznej dyktaturze ludu (30 czerwca 1949 roku), [w:] Wyjatki z dziet Przewodniczacego Mao Tse-tunga (Czerwona ksiażeczka), Wrocław 2005.

Mao Zedong, O nowej demokracji (styczeń 1940 roku), [w:] Wyjatki z dziet Przewodniczacego Mao Tse-tunga (Czerwona ksiażeczka), Wrocław 2005.

Mao Zedong, O właściwym traktowaniu sprzeczności w tonie ludu (27 lutego 1957 roku), [w:] Wyjatki $z$ dziet Przewodniczacego Mao Tse-tunga (Czerwona ksiażeczka), Wrocław 2005.

Mao Zedong, O zagadnieniach uspótdzielczenia rolnictwa (31 lipca 1955 roku), [w:] Wyjatki z dziet Przewodniczacego Mao Tse-tunga (Czerwona ksiażeczka), Wrocław 2005.

Mao Zedong, Przemówienie na jubileuszowej sesji Rady Najwyższej ZSRR z okazji 40-tej rocznicy Wielkiej Socjalistycznej Rewolucji Październikowej (6 listopada 1957 roku), [w:] Wyjatki z dziet Przewodniczacego Mao Tse-tunga Czerwona ksiażeczka), Wrocław 2005.

Mao Zedong, Przemówienie na najwyższej Konferencji Państwowej (25 stycznia 1956 roku), [w:] Wyjatki z dzieł Przewodniczacego Mao Tse-tunga (Czerwona ksiażeczka), Wrocław 2005.

Mao Zedong, Przemówienie na naradzie pracowników kadrowych rejonu wyzwolonego Szansi-suijuan (1 kwietnia 1948 roku), [w:] Wyjatki z dziet Przewodniczacego Mao Tse-tunga (Czerwona ksiażeczka), Wrocław 2005.

Mao Zedong, Przemówienie na naradzie e Jenanie, poświęconej 
zagadnieniom literatury i sztuki (maj 1942), [w:] Wyjątki z dziet Przewodniczacego Mao Tse-tunga (Czerwona ksiazeczka), Wrocław 2005.

Mao Zedong, Przemówienie na ogólnokrajowej naradzie Komunistycznej Partii Chin, poświęconej pracy propagandowej (12 marca 1957 roku), [w:] Wyjątki z dziet Przewodniczacego Mao Tse-tunga (Czerwona ksiażeczka), Wrocław 2005.

Mao Zedong, Rewolucja chińska a Komunistyczna Partia Chin (grudzień 1948 roku), [w:] Wyjątki z dziet Przewodniczącego Mao Tse-tunga (Czerwona ksiażeczka), Wrocław 2005.

Mao Zedong, Rewolucyjne sity całego świata, taczcie się do walki przeciwko imperialistycznej agresji (2 listopada 1948 roku), [w:] Wyjątki z dziet Przewodniczacego Mao Tse-tunga (Czerwona ksiażeczka), Wrocław 2005.

Marks K, Rękopisy ekonomiczno-filozoficzne z 1844 r., [w:] K. Marks, F. Engels, Dzieła, t. 1, Warszawa 1976.

Marks K., Engels F., Ideologia niemiecka. Krytyka najnowszej filozofii niemieckiej w osobach jej przedstawicieli Feuerbacha, B. Bauera i Stirnera, tudzież niemieckiego socjalizmu w osobach różnych jego proroków, [w:] K. Marks, F. Engels, Dzieta, t. 3, Warszawa 1975.

Marks K., Engels F., Manifest komunistyczny, [w:] K. Marks, F. Engels, Dzieta, t. 4, Warszawa 1962.

Masters on Masterpieces of Chinese Opera. A Classic Chinese Reader, Zhonghua Book Company, China 2016.

Marszałek-Kawa J. (red.), Globalna potega Chin. Czynniki i perspektywy, Toruń 2014.

Marszałek-Kawa J., Bidziński M. (red.), Wektory zmian w polityce Chińskiej Republiki Ludowej w okresie rząów Xi Jinpinga, Toruń 2018.

Muszyński J. (red.), Teoria naukowego komunizmu, Warszawa 1979.

Muszyński J., Teoria przechodzenia od kapitalizmu do komuni- 
zmu, [w:] Teoria naukowego komunizmu, red. J. Muszyński, Warszawa 1979.

Pancov A., Mao Czedun, Moskva 2007.

Pimpaneau J., Chiny, kultura i tradycje, Warszawa 2001.

Priestland D., Welt-Geschichte des Kommunismus. Von der Francoesischen Revolution bis heute. Siedler Verlag, Muenchen 2009.

Rakowski M., Przemiany i szanse socjalizmu (w konfrontacji z kapitalizmem od czasów Marksa po bliska przyszłość), Warszawa 2004.

Rakowski M., Ciszewski P., Kres światowej hegemonii USA $i$ świt bezklasowej historii świata. Manuskrypt komputerowy, Warszawa 2019.

Rodziński W., Historia Chin, Wrocław-Warszawa-Kraków-Gdańsk 1974.

Sielski J., Polityczne wzory przywództwa $i$ wtadzy w Chinach, [w:] Wektory zmian w polityce Chińskiej Republiki Ludowej w okresie rzadów Xi Jinpinga, red. J. Marszałek-Kawa, M. Bidziński, Toruń 2018.

Sładkowskij M.I et al (red.), Najnowsza historia Chin 1917-1976, tłum. J. Urkowski, Warszawa 1976.

Słutajski M.L., Gieorgijew W.G., Antimarksistskaya sucznost' fitosowskich wzgladow Mao Tse-tunga, Moskva 1969.

Stępień T., Maurycy Z., Komunistyczna czy Konfucjańska Partia Chin? Krytyka zbyt łatwych wyjaśnień, [w:] Globalna potega Chin. Czynniki i perspektywy, red. J. Marszałek-Kawa, Torun 2014.

Study on the Sinisation History of Marxism, Wuhan 2015. The Chinese Dream. New Progress in China's Human Rights, Beijing 2015.

Terrill R., Mao, bibliografia, Warszawa 2001.

Wiktor Z., Chiny na drodze socjalistycznej modernizacji, Toruń 2008. 
Wiktor Z., Chińska wizja budowy socjalizmu w świetle materiatów XIX Zjazdu KPCh, [w:] Wektory zmian w polityce Chińskiej Republiki Ludowej w okresie rządów Xi Jinpinga, red. J. Marszałek-Kawa, M. Bidziński, Toruń 2018.

Wiktor Z., Wptyw Rewolucji Październikowej w Rosji na zmiany polityczno-ustrojowe w Azji, [w:] System polityczny i kultura prawna państw azjatyckich, Toruń 2018.

Wiktor Z., Rakowski M., Rozwój i prognozy przyszłości Chin w zmieniajacym się świecie. Dokad zmierzają Chiny i świat, Toruń 2012.

Wiktor Z.B., Geneza i rozwój teorii naukowego komunizmu, Wrocław 1986.

Wiktor Z.B., Teoria komunizmu naukowego, Wrocław 1986.

Xi Jinping, Innowacyjne Chiny, Warszawa 2015.

Xi Jinping, Referat Sprawozdawczy XVIII KC KPCh wygtoszony przez sekretarza generalnego, prezydenta Xi Jinpinga, [w:] XIX Krajowy Zjazd Komunistycznej Partii Chin, 18-24 października 2017 roku, Warszawa 2018.

Xi Jinping, Secure a Decisive Victory in Building a Moderattely Prosperous Society in All Respects and Strive for the Great Success of Socialism with Chinese Characteristics 18, 10, 2017, http:www.chinadaily.com.cn/china/19thcpcnationalcongress/2017-11/04/content_34115212.htm.

Xi Jinping, The Governance of China, t. 1, 2, Beijing 2018.

Zhang Weiwei, A New Equilibrium Of Power. The CPC's strong leadership is key to China's success, „Beijing Review”, 19.10.2017, nr 42, s. 13 i n.

Zhao Yongsheng, Financial Reforms in China. From an Institutional View, Beijing 2017.

Zhang Zhouyuan (red.), China's Economic Tendencies under the New Normal, Beijing 2017. 
Zheng Hangsheng, Li Yingsheng, Historia chińskiej socjologii, Toruń 2010.

Zubok Ł.I. (red.), Historia Drugiej międzynarodówki, t. 1, 2, Warszawa 1978.

\section{Abstrakt}

Podstawowa tezą pracy jest analiza różnic i związków przedmiotowych między marksizmem i konfucjanizmem w ideologii Komunistycznej Partii Chin. Problematyka rozwijana jest w kilku aspektach.

1. Uwagi wprowadzające, głównie specyfika ważnych etapów rozwoju chińskiej kultury i cywilizacji i ich stałe oraz zmienne wartości w dziejach Chin. Kontynuacja i dyskontynuacja. Dialektyka rozwoju chińskiej cywilizacji od czasów prehistorycznych do współczesności.

2. Zarys rozwoju konfucjanizmu, przyczyny powstania na przełomie VI i V w. przed naszą erą.

Rozwój kultury i filozofii w starożytnych Chinach. Powstanie konfucjanizmu i jego dalsze dzieje oraz rozwój, neokonfucjanizm. Inne kierunki filozoficzne: taoizm, mochizm, legizm, nurty idealistyczne i materialistyczne. Konfucjanizm jako religia. Konfucjanizm jako podstawa ideologiczna cesarstwa chińskiego. Osłabienie konfucjanizmu po rewolucji 1911 r. i upadku cesarstwa chińskiego.

3. Walka między konfucjanizmem a marksizmem i wkład Mao Zedonga w rozwój marksizmu w Chinach. Pierwsze prace marksistowskie, główni przedstawiciele marksizmu literackiego. Powstanie Komunistycznej Partii Chin - 1921 r. Walka KPCh na dwa fronty: przeciwko rządom burżuazji i pozostałościom konfucjanizmu w ideologii mandarynów i świadomości szerokich mas ludowych. Rola Ma Zedonga w adaptacji marksizmu przez rewolucyjny ruch robotniczy i chłopski. Główne kierunki naukowo-badawcze. Rola przykładu i pomocy Związku Radzieckiego i Międzynarodówki Komunistycznej w przyswojeniu i rozwoju marksizmu-leninizmu. Problem możliwości rewolucji socjalistycznej i budowy socjalizmu w kraju historycznie opóźnionym pod względem rozwoju gospodarczego. Powstanie Chińskiej Republik Ludowej - $1949 \mathrm{r}$. 
4. Budowa podstaw socjalizmu w Chinach w okresie przywództwa Mao Zedonga (1949-1976). Charakter chińskiej rewolucji, rewolucja antykapitalistyczna, antykolonialna, demokratyczna i socjalistyczna. Główne sprzeczności ChRL i sposoby ich rozwiązywania przez władzę ludową. Charakter demokratycznej dyktatury ludu. Uspołecznienie środków produkcji. Gospodarka centralnie planowana. Słabości polityki „opierania się na własnych siłach”. Próby marszu „na skróty” do komunizmu; „Wielki Skok” i „wielka proletariacka rewolucja kulturalna". Odrodzenie konfucjanizmu i walki frakcyjne w KPCh. Rozbieżności i załamanie się międzynarodowego ruchu komunistycznego w latach 60. XX w. Powstanie maoizmu jako „chińskiego marksizmu”. Maoizm w teorii i działaniu ideowo-politycznym KPCh.

5. Charakter reform polityczno-ekonomicznych w epoce Deng Xiaopinga. Socjalistyczna gospodarka rynkowa, polityka otwarcia na kapitał zagraniczny. Zezwolenie na szeroką działalność prywatnego kapitału narodowego. Zachowanie dominacji sektora socjalistycznego w gałęziach strategicznych, społecznej własności ziemi i zasobów naturalnych. Zmiana centralnego planowania na makroekonomiczne i sterownicze. Stosowanie zasad „niewidzialnej ręki rynku” i „widzialnej ręki rządu". Kontynuacja demokratycznej dyktatury ludu i zachowanie kierowniczej roli KPCh. Marksizm-leninizm, Myśl Mao Zedonga jako podstawa ideowo-polityczna rynkowych reform. Próby wykorzystania humanistycznych treści konfucjanizmu w celu umocnienia harmonii społecznej, budowy społeczeństw o umiarkowanej pomyślności, specyfiki chińskiej drogi do socjalizmu, dążenia do realizacji „chińskiego marzenia".

6. Socjalistyczna gospodarka rynkowa a konfucjanizm. Zmiana taktyki nie strategii zdążania oraz budowy socjalizmu i komunizmu. W rzeczywistości jest programem wypełnienia głębokiej luki w bazie materialno-technicznej, sił wytwórczych, głównie nowoczesnego przemysłu, środków komunikacji, której Chiny nie wypełniłyby, gdyby nie ogromna kooperacja z kapitałem zagranicznym, ale na polityczno-ideowych warunkach Chińskiej Republiki Ludowej. Świadczą o tym wielkie osiągnięcia czterdziestu lat nowej polityki ekonomicznej, wyprowadzenie z nędzy ponad $700 \mathrm{mln}$ ludzi, rozwój nowoczesnych gałęzi produkcyjnych, głównie w przemyśle i usługach, powstanie nowoczesnej infrastruktury komunikacyjnej, wysoki poziom edukacji, podnoszenie standardów socjalnych. Chiny stały się drugą gospodarką świata i aspirują do roli wielkiego mocarstwa światowego, mającego ambicje ponoszenia współodpowiedzialności za losy całej planety. W polityce 
zagranicznej dążą do utrzymania pokoju i wzajemnych korzyści. Ważną formą tego programu jest Nowy Jedwabny Szlaki.

Jednocześnie jądrem systemu ideowo-politycznego Chin pozostaje Komunistyczna Partia Chin, która nie zrezygnowała z budowy socjalizmu i na ostatnim XIX Zjeździe Krajowym KPCh w 2017 r. przedstawiła dalekosiężne plany budowy rozwiniętego społeczeństwa socjalistycznego (do 2050 r.). W tej sytuacji KPCh nie obawia się konfucjanizmu, a nawet wykorzystuje jego niektóre humanistyczne treści, kategorie i zasady dla umacniania i rozwoju socjalizmu z chińską specyfiką. W konkluzji można przyjąć, że jest to jedna z głównych cech doktryny (myśli) Xi Jinpinga - obecnego przywódcy KPCh i Przewodniczącego Chińskiej Republiki Ludowej.

Słowa kluczowe: marksizm, marksizm-leninizm, maoizm, konfucjanizm, neokonfucjanizm, taoizm, mothism, legizm, konfucjanizm jako religia, ideologia, chińska cywilizacja i kultura, rewolucja demokratyczna, rewolucja socjalistyczna, Chińska Republika Ludowa, Komunistyczna Partia Chin, teoria Deng Xiaopinga, teoria trzech reprezentacji, teoria naukowego rozwoju, myśl (doktryna Xi Jinpinga, socjalistyczna gospodarka rynkowa, kapitalizm państwowy, socjalizm z chińską specyfiką, walka klasowa w Chinach, aspekty wewnętrzne i zewnętrzne

\section{Abstract}

The main thesis of the article is marxism and confucianism in ideology of Communist Party of China. The problem has ben explained in the historical, gnoseological and epistemological aspects.

The subthesis are:

1. The introduction analyse od Chinese culture and civilisation.

2. Outlet of development of confucianism, the other mainstream philosophies: taoism, mothism legism, the idealistic and materialistic aspects.The development of the confucianism since the antiquity to collaps of Chinese empire (1911).

3. The confrontation between confucianism versus marxism and the contribution to the Chinese marxism by Mao Zedong. The establishing of the Communist Party of China (2021).

4. The establishing of the People's Republic of China (1949). The sites of the Chinese revolution: the anticapitalistic, anticolonial, democratic and socialist revolution. The collaps of the confucianism in the time od Mao Zedong, the development of the marxist studies and the 
marxism-leninism and after maoism in the ideology of the Communist Party of China. The Mao's leadership battle against confucianist factions in the party in the time of "proletarian revolution".

5. The establishing of the Socialist Market Economy in the era of Deng Xiaopin and gradual rejuvenation of the neoconfucianism. The socio-economical results of the socialist markest economy. The rejuvenation of the new national boutgeoisie and the new class contradictions.

6 . The socialist market ekonomy and the rejuvenation of the neoconfucionism. The adaptation by the contemporary leadership of CPC an humanitarian categories and principles of confucionism in the strengthen of social harmony of the Chinese people and in the building of the socialism with the Chinese characteristics, for exemples: Datong, Chinese way, Chinese dream and others.

Keywords: marxism, marxism-leninism, maoism, confucianism, neoconfucianism taoism, mohism, legism, confucianism as the religion, ideology, Chinese civilisation and culture, democratic revolution socialist revolution, People's Republic of China, Communist Party of China, Theory of Deng Xiaoping, Theory of 3 representants, Theory of scientific development, The thought (doctrine) of Xi Jinping, socialist market economy, state capitalism, Socialism, with the Chines characteristics, The class struggle in China - in and out aspects 


\section{Jerzy Sielski}

\section{Komunistyczna Partia Chin i jej przywódcy}

\section{Wstęp}

Dziś Chiny są potęgą gospodarczą i polityczną. Badacze Dalekiego Wschodu zastanawiają się jak nazwać współczesny system polityczny Chin, który ma charakter hybrydowy: totalitaryzm, autorytaryzm, autorytaryzm oświecony czy racjonalny ${ }^{1}$, neoautorytaryzm ${ }^{2}$, oświecona dyktatura w stylu singapurskim. Na pewno system polityczny Chin przechodził różne etapy, od systemu totalitarnego za czasów Mao, poprzez autorytaryzm czasów Denga do dzisiejszej formy, która jest połączeniem neokonfucjanizmu z gospodarką rynkową. Wyodrębniając płaszczyznę gospodarczą to niewątpliwie jest to państwowa (socjalistyczna) gospodarka rynkowa. Dlaczego? To Komunistyczna Partia Chin (dalej Partia) i państwo nadzoruje gospodarkę zarówno państwową, jak i prywatną. Kreśląc płaszczyznę polityczną mamy bezwzględną dominację Komunistycznej Partii Chin, której celem - jak głosi ostatni przywódca Xi Jinping - jest dobrobyt poprzez systematyczny rozwój kraju, aby zrealizować „chiński sen (marzenie)”3

T. Saich, Governance and Politics of China, London 2015.

2 Ch. Zhao, Rational Authoritarianism and Chinese Economic Reform, [w:] Contemporary China: The Dynamics of Change at the Start of New Millennium, red. W.P. Preston, J. Haacke, New York 2018.

3 Liu Houbin, Korzenie historyczne $i$ wktad kulturowy odrodzenia narodu chińskiego, tłum. A. Kowalska, Toruń 2017. 
dlatego też jej sfera polityczna jest najbliżej - autorytaryzmu oświeconego ${ }^{4}$.

\section{Kto ma władzę w dzisiejszych Chinach; partia czy państwo?}

W systemie politycznym Chin możemy wyróżnić cztery podmioty: przywódca, Partia, państwo i społeczeństwo. W systemie autorytaryzmu oświeconego, który podmiot z czterech zaprezentowanych powyżej ma największe szanse na dominacje w chińskim systemie politycznym? Oczywiście, teoretycznie, każdy podmiot ma potencjalne szanse na zdobycie władzy. Ale praktycznie w analizowanym systemie najmniejsze szanse ma społeczeństwo. Dziś władza w Chinach skupiona jest w trzech pierwszych podmiotach i „mówi” do społeczeństwa: jeśli będziecie działać według naszych reguł, to i wy jak i wasze rodziny będziecie się bogacić i żyć spokojnie.

Aby tak „sugerować” społeczeństwu władza polityczna w Chinach ma szereg środków i instrumentów (m.in. wojsko, tajne służby), aby nakłonić obywateli do odpowiedniego zachowania. Dziś władza polityczna nie wtrąca się w życie prywatne, a zarazem zachęca do działalności gospodarczej. Ale gdy obywatele działają niezgodnie z regułami wytyczonymi przez władzę, interweniują w sposób skuteczny, używając także środków przemocowych (od tzw. „czarnych aresztów” ${ }^{5}$ po osadzanie niepokornych dysydentów w więzieniach, a także używania wojska do tłumienie protestów).

Pozostają w naszej analizie trzy podmioty. Na razie zostawmy przywódców chińskich, a przeanalizujmy relacje partia -

4 Zob. A. Bolesta, Chiny w okresie transformacji, Warszawa 2006, s. 81.

5 R. McGregor, Partia. Sekretny świat komunistycznych władców Chin, tłum. M. Król, Kraków 2013, s. 26. 
państwo. Stawiamy hipotezę, że wyższą władzę ma Partia niż państwo. Dlaczego?

Kompetencje Komunistycznej Partii Chin nie są nigdzie uwidocznione w konstytucji, niemniej w preambule konstytucji pięciokrotnie wspomniano o kierowniczej roli Partii. Dlaczego jest ona główną i najważniejszą instytucją w systemie politycznym Chin?

Po pierwsze: dzisiejsze struktury partii rządzącej Chin zostały zaadoptowane ze struktur komunistycznej partii Rosji w okresie wydatnej pomocy tejże partii chińskim komunistycznym przyjaciołom. A to oznacza, że partia rządząca stara się przyporządkować wszystko w państwie według swojej opcji. Włodzimierz Lenin tworząc partię komunistyczną (bolszewicką) w Rosji widział ją jako awangardę klasy robotniczej. W tym ujęciu elita społeczeństwa związana z klasą robotniczą miała zrobić przewrót, a więc odsunąć od władzy władzę kapitalistyczną i ustanowić władzę najpierw socjalistyczną, potem komunistyczną. Struktura partii opierała się na centralizmie demokratycznym. Przy czym w początkowej fazie zarządzanie państwem powinno się opierać na dyktaturze proletariatu. Tylko partia jako awangarda społeczeństwa według Lenina była zdolna do zarządzania państwem. Gdy zaś mówi się o dyktaturze także mamy do czynienia z przemocą. Zaprezentowane powyżej elementy (środki) zostały w pełni urzeczywistnione w ChRL. Z jednym wszak wyjątkiem to nie klasa robotnicza była w Chinach awangardą, lecz chłopi.

Po drugie: to Partia stoi na straży ideologicznej. Wszelkie odejścia od linii przedstawionej przez Politbiuro jest karane. W ostateczności nawet z wydaleniem z Partii. Dla Mao linia ideologiczna była najważniejsza. Mao rozumiał panowanie tak jak konfucjańscy cesarze, przede wszystkim jako „panowanie ideologiczne - neokonfucjanizm zmienił się w mao- 
izm" ${ }^{16}$. Stwierdził on, że świadomość przekształca materialną rzeczywistość. Inaczej mówiąc Mao chciał najpierw stworzyć człowieka socjalizmu i dopiero za jego pomocą zbudować gospodarkę socjalistyczną. Swoją wizję na gospodarkę wyraził poprzez realizację „Wielkiego Skoku”, który w konsekwencji doprowadził do krachu gospodarczego, wielkiego głodu i pochłonął ponad $30 \mathrm{mln}$ ofiar. Od panowania Denga ideologia ma „praktyczny charakter”. Dziś „ostatni cesarz” Xi znów powrócił do ideologii, ale oczywiście nie w takim zakresie jak Mao.

Deng po śmierci Mao (1976 r.) w 1977 r. objął stanowisko pierwszego wicepremiera, wiceprzewodniczącego KPCh oraz wiceprzewodniczącego Komisji Wojskowej.

W 1978 r. wysunął dwa nowe hasła, które co prawda pochodziły z pism Mao z Yan'an, ale Deng nadał im całkowicie inną interpretację. Chcąc „przepchnąć” hasła zarówno w elicie partyjnej, jak i społeczeństwie przywołuje dla bezpieczeństwa pewne wyrażenia z pism Mao, ale nadaje im sens inny, zgodny ze swoimi intencjami. Bardzo pragmatyczne działania. Pierwsze hasło brzmiało: „szukajcie prawdy w faktach” - a nie w dziełach Marksa, Lenina czy Mao. Drugie hasło brzmiało: „praktyka jest jedynym kryterium prawdy”. Nie szukamy prawdy w wypowiedziach czy dogmatach Marksa, Lenina czy Mao, ale czy dana polityka jest praktycznie skuteczna. Chodzi przede wszystkim czy określona polityka przyczynia się czy też nie do podniesienia produkcji i wydajności pracy ${ }^{7}$.

W Chinach łączenie różnych nurtów filozoficznych czy religijnych jest ugruntowane tradycją. Przywódcy jak i mieszkańcy państwa chińskiego w życiu społecznym są konfucjanistami, a w życiu codziennym, prywatnym mogą być toa-

6 J. Pimpaneanu, Chiny. Kultura i tradycje, Warszawa 2001, s. 191.

7 K. Seitz, Chiny. Powrót olbrzyma, Warszawa 2008, s. 200-201. 
istą, szintoistą, buddystą, muzułmaninem, chrześcijaninem. „Świecki konfucjanizm i panteistyczne religie nie wywołują w odróżnieniu od mahometanizmu czy katolicyzmu - oporu wobec adoptowania materialistycznych wzorców cywilizacji przemysłowej" ${ }^{\text {. }}$

Po trzecie: odpowiednia kontrola elit politycznych przez elitę biurokratyczno-polityczną. Elita polityczna okresu ChRL została „naznaczona” przez biurokrację partyjną w postaci „czerwonej maszyny”. „Pekińskie biura oficjeli szczycących się odpowiednią rangą usiane są »czerwonymi maszynami«. Stoją na biurkach ministrów i wiceministrów, redaktorów naczelnych partyjnych gazet, prezesów i prezesek elity państwowych przedsiębiorstw i szefów niezliczonych instytucji pozostających pod kontrolą partii. Przekazy telefoniczne i faksowe szyfruje się nie tylko po to, by zabezpieczyć partyjne i rządowe wiadomości przed zagranicznymi wywiadami. Zapewniają także ochronę przed wścibstwem tych, którzy do systemu nie należą. Posiadanie »czerwonej maszyny« oznacza, że przyjęto cię do doskonale zintegrowanego klubu, który kieruje krajem - do niewielkiej grupy (głównie mężczyzn) odpowiadających za około jedną piątą ludzkości"9. Z jej czterocyfrowymi numerami można się tylko połączyć z innymi podobnymi aparatami o podobnych numerach, pracującymi w obrębie systemu szyfrowania ${ }^{10}$.

Po czwarte: elita partyjna posiadająca telefon czerwony posiada prestiż i pozycję społeczną, dająca z jednej strony przywileje, z drugiej ograniczenia. Prestiż społeczny biurokracji w Chinach ma swoją tradycję. Według McGregora: mają oni we własnym kraju status „dyplomatów”: mieszkają w chronionych dzielnicach, podróże zagraniczne, kontakty z ludźmi spo-

\footnotetext{
8 Ibidem, s. 257-258.

9 R. McGregor, Partia. Sekretny świat komunistycznych władców Chin, tłum. M. Król, Kraków 2013, s. 33.
}

10 Ibidem. 
za innych kręgów, w tym z członkami własnych rodzin, mają się odbywać według ściśle ustalonego protokołu bezpieczeństwa ${ }^{11}$. „Oskarżeni o przestępstwa kryminalne odpowiadają przede wszystkim przed partią, a nie przed obowiązującym prawem i wymiarem sprawiedliwości” ${ }^{12}$.

Ale cena za przynależność do elitarnego klubu też jest wysoka: stres, zaangażowanie, muszą przyjąć wszelkie obowiązki, jakie są im przydzielane, trudno także opuścić Partię, opuszczenie wiążą się negatywnym konsekwencjami.

Po piąte: Komunistyczna Partia Chin jest instytucją zorganizowaną hierarchicznie.

Tablice rejestracyjne samochodów w mieście jednoznacznie wskazują na obowiązującą hierarchię. Sekretarz partii ma numer 00001, burmistrz i zastępca sekretarza partii - 00002, wiceburmistrz i kolejny w hierarchii członek miejskiego komitetu partii - 00003 itd. W mediach we wszystkich oficjalnych oświadczeniach mówi się o „przywódcach partii i państwa”. Wszystko to pokazuje zasadę zwierzchności KPCh nad państwem ${ }^{13}$.

Pod kierownictwem BP działa ogromny i w znacznej mierze niejawny partyjny system, kontrolujący cały sektor publiczny, wojsko, urzędników państwowych pracujących na pięciu poziomach administracji państwowej. Komitety wydają instrukcje polityczne dla nich. W całym kraju działa 2800 partyjnych szkół, gdzie urzędników poddaje się regularnym szkoleniom, niezbędnym do awansów. Gdy partyjny urzędnik, polityk podejrzany jest o przestępstwo, to Partia prowadzi dochodzenie i tylko za jej zgodą może osobnik partyjny być przekazany wymiarowi sprawiedliwości. Partyjne organy nie tylko kontrolują państwowe przedsiębiorstwa i agencje, ale także ważne think

\footnotetext{
11 Ibidem, s. 35.

12 Ibidem.

13 R. McGregor, op.cit., s. 38-39.
} 
tanki, sądy, media, wszystkie uznane przez państwo religie, uniwersytety, instytucje edukacyjne, wpływają bezpośrednio na organizacje pozarządowe, niektóre przedsiębiorstwa prywatne, kontrolują partie tzw. demokratyczne, mianując ich przywódców i finansując je $\mathrm{e}^{14}$.

Po szóste: przez ponad sześćdziesiąt lat KPCh utrzymuje władzę. Powoli odrzuca ideologiczny gorset, wycofuje się także z prywatnego życia chińskich obywateli. Partii udało się połączyć władzę i umocowanie komunistycznego państwa z dynamiką i wydajnością gospodarki w coraz większym stopniu opartej na indywidualnej przedsiębiorczości. Dzisiaj szkoły partyjne mają nie tylko wpajać lojalność, ale i przekazywać nowoczesne koncepcje i umiejętności z zakresu zarządzania.

Po siódme: KPCh dziś odwołuje się także do swojej rodzimej tradycji sprawowania władzy. Następuje renesans osoby Konfucjusza i innych zasad kulturowych związanych z tradycją chińską. Daje to dzisiejszej władzy politycznej legitymizację jako Partii, która w sposób naturalny kontynuuje najwspanialsze tradycje oświeconych epok w dziejach cesarstwa. Autorytarna dzisiejsza biurokracja partyjna to przecież autorytarna centralna biurokracja cesarstwa.

Po ósme: to Partia wybiera przywódcę, a później to on staje na czele partii i państwa, np. przywódca czwartej generacji Hu Jintao skupił trzy najważniejsze funkcje w Partii i państwa: sekretarza generalnego Komunistycznej Partii Chin, Przewodniczący ChRL, dowódcy armii. Praktyką polityczną stało się, że od Jiang Zemina przywódcy Chin (przywódca trzeciej generacji) obejmują przede wszystkim te trzy stanowiska we władzy politycznej Chin.

Z analizy i przedstawionych faktów widać wyraźnie, że to Partia jest na pierwszym miejscu, przed państwem.

14 Zob. szerzej: ibidem. 


\section{Partia - jej przywódcy i liderzy}

Ostatnia kwestia to rozstrzygnięcie, jaki podmiot polityczny jest najważniejszy w systemie politycznym Chin: Partia czy jej przywódcy? W Chinach współczesnych od 1935 r. wyróżnia się pięć generacji przywódców ChRL ${ }^{15}$. Pierwsza generacja związana była z Mao - on był przywódcą, liderami ${ }^{16}$ byli Zhou Enlai (premier), Liu Shaoqi (Przewodniczący ChRL, przewodniczący KC KPCh (1960-1965) i Deng Xiaoping (sekretarz generalny Sekretariatu KC), Hua Guofeng (Przewodniczący KC KPCh 1976-1981), Jiang Qing (żona Mao, przedstawicielka skrzydła radykałów podczas rewolucji kulturalnej).

Druga generacja związana była Deng Xiaopingiem od 1978 do 1989 r., liderami byli Chen Yun (pierwszy sekretarz Centralnej Komisji Kontroli Dyscyplinarnej, później przewodniczący Centralnej Komisji Doradczej od 1992 r.), Hu Yaobang (przewodniczący KC KPCh), Zhao Ziyang (premier).

Trzecia generacja od 1989-2002 miała dwóch przywódców: do 1994 r. Deng Xiaopinga, później Jiang Zemina, liderem był Li Peng (premier), Qiao Shi (uważany za numer trzy po Jiang i Li), Zhu Rongji (Zhu od 1997 r. numer trzeci po odejściu Qiao), Zeng Qinghong (szef Wydziału Organizacyjnego, określany jako polityczny magik odgrywający przy Jiang rolę „przybocznego” (cardinal-at-the-elbow) ${ }^{17}$, wiceprzewodniczący ChRL).

Czwarta generacja (2002-2012) miała także dwóch przywódców: Jiang Zemina do 2004 r. (do tego roku Jiang kierował

15 Zob. J. Bayer, W.J. Dziak, Historia polityczna Chin 1839-2014. Konspekt analityczny, Warszawa 2016, s. 387.

16 Dla mnie przywódca w państwie jest z reguły jeden, a liderów jest zawsze więcej. Zob. J. Sielski, Teoretyczne aspekty przywództwa politycznego. Casus Polski, Toruń 2013.

17 R. McGregor, op.cit., s. 100. 
Centralną Komisją Wojskową), później od 2004 r. - Hu Jintao (sekretarz generalny w latach 2002-2012, Przewodniczący ChRL od 2003 r., od 2004 r. przejął kierownictwo Centralnej Komisji Wojskowej), liderami są: Wu Bangguo (numer 2, szef legislatury - OZPL, funkcjonariusz z Szanghaju), Wen Jaibao (numer 3, premier) ${ }^{18}$.

Piąta generacja ( od 2012 r. - do dziś) ma silnego przywódcę - Xi Jinpinga, który skupił od razu trzy najważniejsze stanowiska (sekretarza generalnego, Przewodniczącego ChRL, dowódcy armii, ale także Centralnej Grupy Kierowniczej ds. Całościowego Pogłębiania Reform), liderzy to: Li Keqiang (numer 2, premier), Li Yuanchao (szef Wydziału Organizacyjnego), Zhang Gaoli (członek Stałego Komitetu BP KC KPCh od spraw wielkich projektów i inicjatyw strategicznych), Zang Dejiang (członek Stałego Komitetu BP KC KPCh od spraw legislacji, Hongkongu, Makao) ${ }^{19}$.

W dalszej części pracy zostaną zarysowane postacie przywódców danej generacji oraz ich stosunek do partii.

\section{Mao Zedong}

Mao Zedong miał wiele twarzy. Przede wszystkim - władcy absolutnego, którego ego potrafiło zmienić prawdę, ludzi dla swojej własnej sławy i wygody. Mao czerpał swoją „aureolę” wodza z historii Chin (syn niebios - cesarz), ze wschodu (Rosji bolszewickiej), ze swojego chłopskiego pochodzenia i umiejętnie manipulując prawdą (wiele wiadomości zatajając, np. działalność w Guomindangu czy wielkie straty w ludziach w okresie „Wielkiego Skoku” czy rewolucji kulturalnej itp.) do-

\footnotetext{
18 Zob. ibidem, s. 31-32.

19 J. Bayer, W.J. Dziak, op.cit., s. 465.
} 
prowadził społeczeństwo chińskie do uwielbienia go, widząc w nim „boga-chłopskiego komunistycznego cesarza” ${ }^{20}$.

Niemniej warto tu nadmienić, że z drugiej strony pozostawił po sobie potęgę atomową, która liczyła się w świecie (pomoc Korei podczas konfliktu). Maoizm stał się inną wersją komunizmu, która był wzorem dla przedstawicieli lewicy na całym świecie. Która z tych „twarzy” jest prawdziwa. Współczesne władze chińskie mówią, że stosując chińskie kryterium oceny, w przypadku Mao wynosi ona trzydzieści do siedemdziesięciu procent. Trzydzieści procent za błędy, siedemdziesiąt za zasługi.

W prowadzonej przez siebie polityce nie było miejsca na moralność. Identyfikował się z najbardziej okrutnymi cesarzami Chin, odczuwał największy podziw wobec najbardziej bezwzględnych i okrutnych tyranów. Był gotów się posłużyć najbardziej brutalnymi metodami, by zrealizować swoje zamierzenia ${ }^{21}$. „Królował” nad Partią, w czasie rewolucji kulturalnej chciał rozbić partię, twierdząc, że jest zbyt konserwatywna.

\section{Deng Xiaoping}

Deng wraz z Mao są rewolucjonistami, „przechodząc” „Wielki Marsz". Pierwszy okres to dominacja Mao, ale po błędach „Wielkiego Skoku” i rewolucji kulturalnej, przyszedł czas Denga.

Punktem zwrotnym w karierze politycznym Denga była śmierć Mao (9 września1976 r.). Wkrótce aresztowano grupę radykałów maoistowskich tzw. „bandę czworga” na czele z Jiang Qing (żoną Mao). Chwilowym sukcesorem został $\mathrm{Hu}$

20 Szerzej zob. J. Sielski, Mao Zedong - „chtopski komunistyczny cesarz Chin", [w:] W kręgu historii, politologii i emigracji, red. K. Leszczyńska, Toruń 2018.

21 Li Zhisui, Prywatne życie przewodniczacego Mao, tłum. Z. Zaczyn, Warszawa 1996, s. 118. 
Guofeng (premier i przewodniczący partii). Deng został zrehabilitowany po raz trzeci i odzyskał swoje stanowiska. W 1977 r. na III Plenum KC KPCh (16-21 lipca) Deng faktycznie przejął nadzór nad rozwojem kraju ${ }^{22} .1978 \mathrm{r}$. Deng ogłosił program modernizacji kraju, kładący nacisk na rynkowe mechanizmy w gospodarce (polityka czterech modernizacji). Dziś przyjmuje się, że 1978 r. był trzecim przełomem rewolucyjnym w XX w. w dziejach Chin (I - 1911 r. obalenie monarchii i proklamowanie republiki; II - 1949 r. utworzenie ChRL). Kierował partią, wojskiem, państwem aż do 1994 r. piastował stanowiska drugorzędne, ale swoją charyzmatycznością i siłą polityczną faktycznie kierował Chinami. Naczelny przywódca (ang. paramont leader $)^{23}$. Decydent strategiczny. Twierdził, że decyzje w Chinach są podejmowane za jego czasu - kolektywnie ${ }^{24}$.

Podobnie jak Mao swoją charyzmatycznością i siłą „królował nad Partią, ale inaczej. Patriarcha nad kolektywem kierowniczym (oprócz Denga w 1981 do kolektywu kierowniczego należał Hu Yaobang - przewodniczący KC KPCh, Zhao Ziyang - premier). Jego zdecydowaniu i silnej osobowości Chiny zawdzięczają dalsze wdrożenie reform po krwawej i tragicznej demonstracji na placu Tianemann w 1989 r., Deng, chcąc zneutralizować przeciwników reform (tzw. neomarksistów), wybrał się na propagandową wyprawę do południowych Chin.

\section{Jiang Zemin}

Kompromisowy kandydat dla frakcji konserwatywnej i reformatorskiej, sam nie należał do żadnej. Dobrze wykształcony,

\footnotetext{
22 J. Bayer, W.J. Dziak, op.cit., s. 253.

23 Ibidem, s. 389.

24 Szerzej zob. Hu Angang, Chińska prezydencja kolektywna, tłum.
} M. Pieczatowska-Mysiak, Toruń 2017. 
znający świetnie angielski i dobrze rosyjski, utalentowany muzycznie i technicznie. Pochodzi z rodziny prozachodniej lewicowej. W 1947 r. wstąpił do nielegalnej KPCh. Najpierw robił karierę na stanowiskach technicznych. Po śmierci Mao został wysłany Szanghaju, aby ożywić miasto, przywracając kadrę techniczną do pracy. W tym momencie rozpoczął karierę polityczną. Jego zadaniem m.in. było uruchomienie pierwszych Specjalnych Stref Ekonomicznych.

W 1982 r. został wiceministrem w Państwowej Komisji Planowania, aby stworzyć „cywilizację informatyczną” w Chinach. Został członkiem KC. W 1984 r. Chiny umieszczają $\mathrm{w}$ kosmosie satelitę geostrategiczną - programem kierował Jiang. W 1985 r. został merem Szanghaju, potem zaś w 1987 r. sekretarzem partyjnym tegoż miasta. W tym samym roku został także członkiem Stałego Komitetu BP. Wyróżniał się umiejętnością rozwiązywania trudnych konfliktowych problemów w Szanghaju, gdy w 1986 r. doszło do demonstracji studenckich w mieście. Zastosował wszystkie środki polityczne, jak i administracyjne. Nie było ofiar, a jego zdecydowanie w działaniu ocenione zostało w Pekinie wysoko. Dlatego też w 1989 r. objął stanowisko kierownictwa partii po zbyt liberalnym Zhao Ziyangu (sekretarzem generalnym KC). Gdy Deng zrezygnował z patronatu nad wojskiem, to właśnie on objął te stanowiska. W 1993 r. został także szefem państwa - największa kumulacja władzy. Przejmuje po śmierci Denga jego sukcesję, wprowadzając Chiny na salony światowe. Propaganda partyjna i państwowa przedstawia go jako przywódcę po Mao i Dengu. Stara się prowadzić Chiny specyficzną trzecią drogą.

Jiang najpierw uzależniony od Denga (do 1994 r.), potem powoli zdobywa autorytet, niemniej to Partia tutaj ma nad nim przewagę. Przywództwo kolektywne - primus inter pares. 


\section{Hu Jintao}

Hu jest przedstawicielem czwartej generacji przywódców ChRL. Pochodzi z Jixi w prowincji Anhui. Urodził się w grudniu 1942 r. Hu wstąpił w kwietniu 1964 r. do KPCh. Ukończył Wydział Inżynierii Wodnej Uniwersytetu Tsinghua w 1964 r., gdzie specjalizował się w badaniach węzłów wodnych. Jako absolwent uniwersytetu posiada tytuł inżyniera. W latach siedemdziesiątych $\mathrm{Hu}$ zajmował odpowiedzialne stanowiska w prowincji Gansu, a następnie w Tybetańskim Regionie Autonomicznym. W 1982 r. został przewodniczący Ogólnochińskiej Federacji Młodzieży. Po przeprowadzce do Pekinu w latach 90. został prezesem Centralnej Szkoły Partyjnej. Później szczebel po szczeblu zajmował coraz wyższe stanowiska partyjne i państwowe, aż od 2002 r. kiedy to został wybrany na sekretarza generalnego KPCh. W 2004 r. objął trzy najważniejsze stanowiska w Partii i państwie (sekretarz generalny KC, Przewodniczący KPCh, przewodniczący Komisji Wojskowej) ${ }^{25}$. W porównaniu do swoich poprzedników prezentowany przywódca był bezbarwny, był wcieleniem zawodowego partyjnego biurokraty. Grzeczny, skromny, unikał rozgłosu. R. McGregor twierdzi, że jego postawa w dużej mierze uczyniła go właściwym człowiekiem na ówczesne czasy. „Złożoność chińskiej rzeczywistości sprawia, że partia, ludzie równi mu rangą, a nawet zwykli ludzie nie byliby dziś w stanie znieść rządów silnej ręki, podobnych do rządów Mao czy Denga. W ich czasach przywódcy wyraźnie górowali nad partią. Hu, mimo całej posiadanej władzy, żył w cieniu partii, zamiast rzucać na nią własny cień"26. W pierwszym okresie sprawowania najwyższej władzy, kreował wizeru-

25 http://www.chinavitae.com/biography/Hu_Jintao/full [dostęp: 13.05.2019].

26 R. McGregor, op.cit., s. 31. 
nek samego siebie jako „łaskawego cesarza”, który interweniuje w politykę mądrze, ale rzadko ${ }^{27}$.

Wiedział, gdzie jego miejsce, nie miał silnego zaplecza politycznego, dlatego też postanowił być w cieniu, rządzić i oprzeć się na kolektywie kierowniczym.

\section{Xi Jinping}

W odróżnieniu od Hu Xi jest postacią wielobarwną, silną i charyzmatyczną. Od razu zgromadził najwięcej władzy, odchodząc od wprowadzonego przez Denga modelu „kolektywnego kierownictwa”. Za czasów Hu był „żołnierzem od specjalnych zadań” (spacyfikowanie „grupy szanghajskiej”, szykował Expo 2010, odpowiadał za organizację olimpiady w Pekinie i obchodów 60-lecia ChRL, usuwania skutków trzęsienia ziemi w Syczuanie itd.).

Xi reprezentuje piątą generację chińskich przywódców, zaliczany jest do tzw. Partii Książąt (syn Xi Zhongxuna - weterana walk rewolucyjnych z lat 30., późniejszego wicepremiera, po śmierci Mao - gubernator prowincji, był w awangardzie reform). W odróżnieniu od poprzednich generacji przywódców (Jiang inżynierów, Hu technokratów) ekipa dzisiejsza to liberałowie, prawnicy, menadżerowie.

Naczelnym hasłem Xi w polityce to hasło „chiński sen” Chiny mają się stać hegemonem a społeczeństwo chińskie będzie - bogate, ekologiczne i silne. On sam natomiast będzie walczył z korupcją i tworzył Nowe Chiny - w marcu 2018 r. parlament zmienił konstytucję i „usunął” przepis o dwukadencyjności władz chińskich. Xi może rządzić długo... Bardzo dba o swój wizerunek w społeczeństwie, ma twarz „brata łata”, przyjaciela i opiekuna ludu, „wujaszka”, z którym każdy może

27 Ibidem, s. 29. 
porozmawiać (zestaw wujka Xi, zestaw przewodniczącego) ${ }^{28}$. Ale także twardego przywódcy, który ukarze każdego urzędnika, gdy zajdzie potrzeba. Tygodnik „The Economist” widzi w nim najpotężniejszego człowieka na świecie ${ }^{29}$.

Jego działania antykorupcyjne okazały się największą czystką w partii od czasu rewolucji kulturalnej (2014 r. - 200 tys. osób na wszystkich szczeblach władzy). Niektórzy badacze i media porównują go do Mao. Nic mylnego. Xi jest bardzo tradycyjnym władcą w porównaniu do Mao, który opierał się w swoich działaniach na legistach, Xi na konfucjanizmie. Wizerunek taki propaguje jego partia. Często nazywa się go poufale „Xi Dada”, co w swobodnym tłumaczeniu oznacza: „Ojczulek Xi”. W Internecie można znaleźć film w stylu gry komputerowej, pokazujący drogę Xi na szczyt władzy. Bohater musi zdobyć poszczególne poziomy, aby osiągnąć poziom „Szefa państwa jako Super Mario”30.

Xi Jinping „króluje” nad Partią, ale inaczej niż Mao czy Deng, umiejętnie rozgrywa partyjne „gierki”(zresetowanie dwukadencyjności), świetny wizerunek zarówno w kraju (sukcesy w walce antykorupcyjnej, obraz „Ojczulka Xi”), jak i na świecie (wizerunek najpotężniejszego człowieka w „The Economist”). Wszystko to powoduje, że jego obraz daje mu „wizerunek silnego przywódcy" z zadatkiem na charyzmatyczność.

\section{Zakończenie}

Celem artykułu było zaprezentowanie i interpretacja, jakie podmioty polityki we współczesnych Chinach pełnią najwyż-

28 W. Kruczkowska, Pierożki w stużbie ChRL, „Gazeta Wyborcza”, 11.02.2014.

29 Xi chińskim Putinem?, „Polityka”, 18.10-25.10.2017, nr 42.

30 Ostatni cesarz, „Forum”, 2014, nr 24, s. 28-31. 
szą funkcję w państwie: przywódca, partia $\mathrm{KPCh}$, państwo i społeczeństwo?

Z analizy stanu faktycznego wynika, że dziś na pewno ani państwo, ani społeczeństwo nie są na tyle silne i zorganizowane, aby w sposób istotny wpływać na władzę polityczną. System polityczny autorytaryzmu oświeconego na pierwszym miejscu stawia silną władzę, dlatego też podmiotami prymarnymi, które liczą się w chińskim układzie politycznym jest Partia i jej przywódca. Gdy na czele KPCh stała/stoi silna osobowość polityczna (Mao, Deng, Xi), wtedy to on rządził i władał partią, państwem i społeczeństwem. Gdy zaś na czele KPCh stała „niezbyt silna” osobowość (Jiang i Hu), to Partia wtedy miała przewagę nad swoimi przywódcami.

Trzej (Mao, Deng, Xi) silni i charyzmatyczni przywódcy mieli osobowości różnorodne, przeto inaczej potrafili „zbudować" swoją przewagę nad Partią.

Mao był władcą absolutnym, Deng był naczelnym przywódcą (paramont leader), to on był decydentem strategicznym, on narzucał swoją wizję "nowych silnych Chin”.

Innym przywódcą jest Xi, odmiennie od Mao i Denga panuje nad Partią innymi metodami - odpowiednią "grą partyjną", świetnym wizerunkiem w kraju i na świecie. Można powiedzieć, że umiał połączyć zalety Mao i Denga, tworząc własny wizerunek silnego i charyzmatycznego przywódcy.

\section{Bibliografia}

Bayer J., Dziak J.W., Historia polityczna Chin 1839-2014. Konspekt analityczny, Warszawa 2016.

Bolesta A., Chiny w okresie transformacji, Warszawa 2006.

$\mathrm{Hu}$ Angang, Chińska prezydencja kolektywna, tłum. M. Pieczatowska-Mysiak, Torun 2017. 
http://www.chinavitae.com/biography/Hu_Jintao/full.

Kruczkowska W., Pierożki w stużbie ChRL, „Gazeta Wyborcza”, 11.02.2014.

McGregor R., Partia. Sekretny świat komunistycznych władców Chin, tłum. M. Król, Kraków 2013.

Li Zhisui, Prywatne życie przewodniczacego Mao, tłum. Z. Zaczyn, Warszawa 1996.

Liu Houbin, Korzenie historyczne i wktad kulturowy odrodzenia narodu chińskiego, tłum. A. Kowalska, Toruń 2017.

Ostatni cesarz, „Forum” 2014, nr 24.

Pimpaneanu J., Chiny. Kultura i tradycje, Warszawa 2001.

Saich T., Governance and Politics of China, London 2015.

Seitz K., Chiny. Powrót olbrzyma, Warszawa 2008.

Sielski J., Teoretyczne aspekty przywództwa politycznego. Casus Polski, Toruń 2013.

Sielski J., Mao Zedong - „chłopski komunistyczny cesarz Chin”, [w:] W kręgu historii, politologii i emigracji, red. K. Leszczyńska, Toruń 2018.

Zhao Ch., Rational Authoritarianism and Chinese Economic Reform, [w:] Contemporary China: The Dynamics of Change at the Start of New Millennium, red. W.P. Preston, J. Haacke, New York 2018.

Xi chińskim Putinem?, „Polityka”, 18.10-25.10.2017, nr 42.

\section{Abstrakt}

W artykule mam zamiar zaprezentować i zinterpretować, jakie podmioty polityki we współczesnych Chinach pełnią najwyższą funkcję w państwie: przywódca, partia KPCh, państwo i społeczeństwo?

$\mathrm{Z}$ analizy stanu faktycznego wynika, że dziś na pewno zarówno państwo, jak i społeczeństwo nie są na tyle silne i zorganizowane, aby w sposób istotny wpływać na władzę polityczną. System polityczny autorytaryzmu oświeconego na pierwszym miejscu stawia silną władzę, dlatego też podmiotami prymarnymi, które liczą się w chińskim ukła- 
dzie politycznym jest Partia i jej przywódca. Gdy na czele KPCh stała/ stoi silna osobowość polityczna (Mao, Deng, Xi), wtedy to on rządził i władał partią, państwem i społeczeństwem. Gdy zaś na czele KPCh stała „niezbyt silna” osobowość (Jiang i Hu), to Partia wtedy miała przewagę nad swoimi przywódcami.

Słowa kluczowe: władza polityczna Chin, KPCh, przywódcy

\begin{abstract}
In the article I present and interpret what subjects have the highest functions in the contemporary China: a leader, Communist Party of China, administration or the society?

The analysis proves that nowadays neither the administration nor the society are strong enough to significantly influence on the political power. The political system of enlightened authoritarianism puts on the first place strong authority. That is why subjects that primarily count in the Chinese political power arrangement are the party and its leader. When the party is led by a charismatic and politically strong persona (Mao, Deng, Xi), then that person rules the party, the society, and the state. If the party is led by a leader that lacks this trait (Jiang, $\mathrm{Hu}$ ), then the party becomes superior.
\end{abstract}

Keywords: political power in China, the CPC, leaders, leadership 


\section{Chiny wobec decyzji traktatu wersalskiego - Ruch 4 Maja}

Decyzje podjęte po zakończeniu I wojny światowej podczas konferencji pokojowej w Paryżu przyniosły poważne skutki polityczne o skali globalnej. W Europie rozpadały się i tworzyły nowe podmioty państwowe, zmienił się układ sił głównych mocarstw, wśród których na pierwszą pozycje wysunęły się Stany Zjednoczone Ameryki. Stopniowo wykształcał się bipolarny system stosunków międzynarodowych, który ostateczną formę osiągnął po II wojnie światowej. Pod wpływem idealistycznej wizji świata amerykańskiego prezydenta Woodrow Wilsona powstała Liga Narodów, powszechna międzynarodowa organizacja, której głównym zadaniem miało być zapewnienie „terytorialnej integralności i politycznej niezawisłości”' jej członków oraz nadzór nad realizacją postanowień traktatu wersalskiego, regulującego globalne zasady międzynarodowych stosunków politycznych i gospodarczych, wyrażonych przez W. Wilsona w programie tzw. „14 punktów”, ogłoszonych w Kongresie 8 stycznia 1918 r. Jednak wśród be-

1 W. Wilson, Ksztattowanie losów świata. Pamiętniki i dokumenty, t. I, tłum. A. Tretiak, Warszawa 1924, s. 211.

2 S. Jones, The Fourteen Points of Woodrow Wilson's Plan for Peace (7.07.2019), https://www.thoughtco.com/the-fourteen-points-3310117 [dostęp: 5.08.2019]; R. Wilde, Woodrow Wilson's Fourteen Points (29.03.2019), https://www.thoughtco.com/woodrow-wilsons-fourteen-points-1222054 [dostęp: 5.08.2019]. 
neficjentów „nowego porządku światowego” nie znalazły się Chiny, pomimo że Państwo Środka wzięło udział w wojnie po stronie państw ententy. Decyzje, które zapadły podczas konferencji w Paryżu godziły w chińską rację stanu, utrzymując ten kraj w roli gospodarczego zaplecza umacniających swoje pozycje mocarstw, zwłaszcza Japonii, której przyznano prawa do niemieckich koncesji w Chinach. Ogólnospołeczny protest znalazł upust w rewolucyjnym Ruchu 4 Maja, który z Pekinu rozprzestrzenił się na wszystkie główne miasta Republiki Chin, ujawniając nowe oblicze chińskiego społeczeństwa.

100-letnia rocznica tych wydarzeń daje asumpt do podjęcia rozważań mających na celu ustalenie właściwych przyczyn wybuchu Ruchu 4 Maja i jego wpływu na kształtowanie wewnętrznych stosunków społecznych i zmiany zachodzące w chińskiej przestrzeni społeczno-politycznej. Rozważania przedstawione w niniejszym artykule skoncentrowano głównie na syntetycznym ujęciu problematyki zmian zachodzących w środowisku międzynarodowym, zwłaszcza polityki mocarstw wobec Chin oraz zjawiskach zachodzących w chińskim społeczeństwie, których Ruch 4 Maja był konsekwencją.

\section{Stan środowiska międzynarodowego Chin i zmiany systemu stosunków międzynarodowych $\mathrm{w}$ regionie Dalekiego Wschodu}

Wybuch I wojny światowej wywołał istotne zmiany w przestrzeni stosunków międzynarodowych na Dalekim Wschodzie. Znacznie spadła aktywność polityczna i gospodarcza głównych mocarstw europejskich, zwłaszcza Wielkiej Brytanii, Francji i Rosji, zaś Niemcy, z uwagi na zaangażowanie w działaniach wojennych w Europie, całkowicie zrezygnowały z rozwoju i ochrony swoich wpływów na tym obszarze. Jedynymi aktyw- 
nymi aktorami pozostali Stany Zjednoczone i Japonia, która wykorzystując położenie geograficzne i warunki geopolityczne będące konsekwencją wcześniejszych zdobyczy terytorialnych w Mandżurii, Riukiu, Tajwanu i Peskadorów³ ${ }^{3}$ osiągnęła korzystniejszą pozycję niż Stany Zjednoczone, które nie dysponowały stałymi bazami militarnymi w Chinach.

Niezależnie od sytuacji w Europie, zarówno Wielka Brytania, jak też Francja i Rosja, dysponując znacznymi siłami zbrojnymi, utrzymywały zdobyte wcześniej strefy wpływów na Dalekim Wschodzie i Państwie Środka, zaś relacje między mocarstwami były konsekwencją poziomu zaangażowania w wojnie światowej i grożących konsekwencji. Wielka Brytania i Francja uznawały Japonię za sojusznika i liczyły na pomoc w działaniach militarnych przeciwko Niemcom na Morzu Śródziemnym, Rosja także Rosja radziecka, pamiętając porażkę w wojnie z Japonią w 1905 r. raczej prowadziła wobec Japonii politykę układową ${ }^{4}$. Stany Zjednoczone wykazywały chwiejne stanowisko wobec ekspansji japońskiego imperializmu w Azji Wschodniej: z jednej strony czynnik japoński uznawano za istotny element ograniczania ekspansji Rosji carskiej, a następnie Rosji radzieckiej, z drugiej zaś Waszyngton dostrzegał japońską presję ekspansjonistyczną w regionie jako zagrożenie dla głównie gospodarczych interesów USA. W owym czasie Stany Zjednoczone, pomimo znacznego potencjału ekonomicznego, nie dysponowały jeszcze na tyle istotnym wsparciem militarnym, by wchodzić w otwarty konflikt z którymkolwiek z konkurentów. Wyrazem tego była ogłoszona we wrześniu 1899 r. przez sekretarza stanu Johna Haya doktryna „otwar-

3 Szerzej: T. Halik, Stosunki Chin z obcymi mocarstwami od połowy XIX w. do lat 30. XX w., [w:] Nowożytna historia Chin, red. R. Sławiński, Kraków 2005, s. 83-94.

4 Szerzej: J. Osterhammel, British business ich China, 1860s-1950s, Cambridge 1989, s. 189-216. 
tych drzwi" w stosunkach z Chinami i relacjach z innymi mocarstwami w związku z ich presją gospodarczą wobec Chin. Głównym jej założeniem było sankcjonowanie przez Stany Zjednoczone zasady podziału Chin na strefy wpływów Wielkiej Brytanii, Japonii, Niemiec, Francji, Rosji $i^{5}$, przy jednoczesnym zabezpieczeniu prawa Amerykanów do swobodnego prowadzenia działalności w każdej ze stref na zasadach „równych możliwości” i „równych praw innych narodów”, zwłaszcza w obszarach handlu i żeglugi, przy zachowaniu terytorialnej integralności terytorialnej Chin ${ }^{6}$. Stosunki między mocarstwami regulowały dwustronne porozumienia gwarantujące nienaruszalność interesów w regionie. Już w 1907 r. zostały zawarte porozumienia między Japonią i Francją, Rosją i Japonią oraz Rosją i Wielką Brytanią, Japonią i Wielką Brytanią, w 1908 r. między Stanami Zjednoczonymi i Japonią. Kolejne porozumienie rosyjsko-japońskie zostało zawarte w 1910 r., uszczegółowione w 1912 r. Poza zapisami dotyczącymi podziału wpływów w Mandżurii zawierało zobowiązanie obu stron do „nienaruszania specjalnych interesów każdej z nich, wzajemną swobodę działań mających na celu obronę i dalsze umocnienie swoich interesów, powstrzymywanie się od jakiejkolwiek politycznej aktywności w sferze specjalnych interesów każdej ze stron". Porozumienie miało jednoznacznie antyamerykański charakter, skierowany przeciwko wzmocnieniu pozycji Stanów Zjednoczonych w regionie. Rosja liczyła na neutralizację działań Japonii, zaś Japonia na poparcie Rosji w związku

5 Do głównych stref wpływów mocarstw w Chinach zaliczyć należy: Wielka Brytania - Hongkong i dorzecze Yangze; Japonia - Tajwan, Wyspy Riukiu i prowincja Fujian; Francja - prowincja Yunnan; Niemcy - prowincja Shandong; Rosja - Mandżuria. Por. A. Malicka (red.), Najnowsza historia Chin, tłum. M. Derenicz, Warszawa 1954, s. 17-18.

6 Z. Góralczyk, Komunistyczna Partia Chin a Stany Zjednoczone (lipiec 1921-czerwiec 1950), Warszawa 1981, s. 42-43. 
z zamiarami dalszej aneksji Chin 7 . W 1911 r., pod naciskiem dyplomacji waszyngtońskiej, miała miejsce rewizja brytyjsko-japońskiego traktatu sojuszniczego, zgodnie z którym Wielka Brytania zwolniona została z obowiązku występowania po stronie Japonii w przypadku konfliktu zbrojnego ze Stanami Zjednoczonymi ${ }^{8}$.

Do układów tych nie zostały włączone Niemcy, których formalną działalność sankcjonował jedynie traktat zawarty z Chinami 6 marca 1898 r. ${ }^{9}$, na mocy którego Niemcy uzyskały prawo monopolu na budowę kolei i eksploatację bogactw naturalnych półwyspu Shandong, utworzenie w Quingdao (Cz'ingtao) bazy wojskowej i 99-letnią dzierżawę terytorium leżącego nad Zatoką Jiaozhou (Cziaoczou). Początkowo Niemcy prowadzili działalność eksploatacyjno-inwestycyjną w prowincji Shandong wspólnie z Brytyjczykami, lecz ujawniające się sprzeczności w relacjach brytyjsko-niemieckich sprawiły, iż początkowa współpraca ustąpiła miejsce zaciętej rywalizacji o chiński rynek ${ }^{10}$, niemniej nic nie ograniczało Niemcom swobodnej działalności, przy czym wykazywali wobec chińskiej ludności niepohamowaną brutalność i zachłanność, „wzburza-

7 I.R. Saveliev, Y.S. Pestushko, Dangerous Rapprochement Russia and Japan in the First World War, 1914-1916, http://src-h.slav.hokudai.ac.jp/ publictn/acta/18/igor-yuri.pdf [dostęp: 7.07.2019].

8 Szerzej: I. Burlingas, Stosunki międzynarodowe na Dalekim Wschodzie w latach 1904-1914, [w:] Historia polityczna Dalekiego Wschodu od końca XVI w do 1945 r., red. J. Żukow, M. Sładkowski, A. Dubinski, tłum. H. Jaźwińska, Warszawa 1981, s. 261-289.

9 Siły zbrojne Niemiec miały wiodące znaczenie w tłumieniu tzw. „powstania bokserów" w Chinach i udziale w ekspedycji zbrojnej przeciwko władzom Mandżurskim w Xi’anie. 7 września 1901 r. przedstawiciel rządu chińskiego podpisał tzw. „Protokół końcowy” z przedstawicielami jedenastu państw sprzymierzonych, w tym Niemiec. Szerzej: T. Halik, Powstanie „Yihetuan” (1898-1901), [w:] Nowożytna historia Chin, red. R. Sławiński, Kraków 2005, s. 95-105.

10 S.L. Tychwinski (red.), Historia nowożytna Chin, tłum. M. Wolska, Warszawa 1979, s. 348. 
jąc Chińczyków do ostateczności”11. Oddziały kierowane przez feldmarszałka hr. Von Waldersee do pacyfikacji buntowników działały wyjątkowo brutalnie paląc wsie i zabijając wszystkich odmawiających posłuszeństwa ${ }^{12}$.

Wybuch I wojny światowej zaktywizował działalność Japończyków, którzy wykorzystali zmianę uwarunkowań geopolitycznych do przejęcia kontroli nad terenami wchodzącymi w skład koncesji niemieckich. Działań Tokio nie powstrzymała deklaracja chińskiego rządu o zachowaniu neutralności i propozycja Waszyngtonu zachowania status quo na Dalekim Wschodzie. 15 sierpnia 1914 r. rząd japoński wystosował do Niemiec ultimatum z żądaniem, aby Niemcy „bez jakichkolwiek warunków i bez jakiejkolwiek rekompensaty" przekazały Japonii terytoria nad Zatoką Jiaozhou, które miałyby zostać przekazane Chinom. Rząd Niemiec pozostawił ultimatum bez odpowiedzi, wobec czego 23 sierpnia Japonia wypowiedziała Niemcom wojnę i skutecznie zaanektowała niemiecką koncesję w Chinach oraz szereg wysp na Pacyfiku pozostających dotychczas we władaniu Niemiec ${ }^{13}$. Operacje sił zbrojnych Japonii odbywały się przy niemrawym proteście Stanów Zjednoczonych i Wielkiej Brytanii. Kolejne wydarzenia potwierdziły, iż japońska deklaracja zwrotu Chinom zajętych terenów okazała się wyłącznie pretekstem w potyczce dyplomatycznej. 7 stycznia 1915 r. rząd japoński odrzucił memorandum rządu chińskiego wzywające do wycofania wojsk z Shandongu w związku z ustaniem oporu wojsk niemieckich i zakończenia działań wojennych, zaś 18 stycznia przedstawiciel Tokio w Pekinie przedstawił rządowi

11 G. Jefimow, Zarys nowożytnej $i$ wspótczesnej historii Chin, tłum. M. Derenicz, Warszawa 1953, s. 142.

12 I. Epstein, Rewolucja w Chinach trwa, Warszawa 1949, s. 33.

13 W.M. Chwostow, Walka dyplomatyczna w okresie pierwszej wojny światowej, [w:] Historia dyplomacji 1914-1939, t. III, red. A.A. Gromyko et al.), Warszawa 1973, s. 6. 
Chin tzw. „21 żądań”, których akceptacja równałaby się z całkowitym pozbawieniem suwerenności i przekształceniem Chin w japońską kolonię ${ }^{14}$. Miał być to kolejny po traktacie z Shimonosheki ${ }^{15}$ upokarzający układ chińsko-japoński, dający Tokio pełne zwierzchnictwo i nieograniczone wpływy na politykę wewnętrzną i zagraniczną Chin, a zwłaszcza w obszarach gospodarki i sił zbrojnych.

Po nieudanych próbach przeciwdziałania aneksji przez Japonię prowincji Shandong, z obawy przed „zamknięciem drzwi" do Chin, dyplomacja amerykańskiego prezydenta Woodrow Wilsona podjęła próbę przejęcia kontroli nad rządem Chin i zmotywowania chińskich władz do popierania „pokojowej” polityki. We wrześniu 1914 r. został podpisany chińsko-amerykański układ o współdziałaniu na rzecz powszechnego pokoju ${ }^{16}$, zgodnie z którym wszelkie spory o charakterze międzynarodowym podlegać miały rozstrzyganiu przez arbitraż międzynarodowy, który de facto nigdy nie został powołany i nie podjął rozstrzygania żadnych spraw. Zawarcie układu dało Pekinowi podstawę do oczekiwania wsparcia w związku z japońskimi „21 żądaniami”. Chiny liczyły także na pomoc

14 Szerzej: M. Sładkowski, Chiny i Japonia, Warszawa 1975, s. 157; I. Burlingas, op.cit., s. 302-303.

15 Traktat z Shimonoseki został zawarty po przegranej wojnie Chin z Japonią 17 kwietnia 1895 r. Ustalał niezależność Korei od Chin, dzięki czemu mogła rozwinąć się japońska ekspansja w tym kraju. Chiny utraciły na korzyść Japonii Peskadory, Tajwan oraz półwysep Liaodong z twierdzą Port Arthur oraz otwierał chińskie porty dla nieograniczonego japońskiego handlu i przemysłu, także w innych otwartych miastach i portach. Pod naciskiem Rosji, Francji i Niemiec punkt o przejęciu Liaodongu usunięto i w jego miejsce wprowadzono postanowienie o chińskiej kontrybucji dla Japonii w wysokości 30 mln liangów. Pełny tekst traktatu: Treaty of Shimonoseki, http://www.taiwandocuments.org/shimonoseki01.htm [dostęp: 5.04.2019]. Szerzej: A. Skřivan Jr., A. Skřivan Sr., Great Powers and the Sino-Japanese War 1894-1895, http://cejsh.icm.edu.pl/cejsh/contributor/9166dddb9ad73f6de6e47e7d2f444b0d [dostęp: 5.04.2019]; S.L. Tychwinski (red.), op.cit., s. 306-307.

16 I. Burlingas, op.cit., s. 301. 
europejskich państw i zdecydowanie odrzuciły japońskie żądania, wyrażając zgodę na podjęcie negocjacji w sprawach dotyczących relacji dwustronnych w zakresie działalności Japonii w Shandongu, Mandżurii i Mongolii Wewnętrznej. Jednocześnie wyraził zgodę na przedłużenie terminu dzierżawy Port Arthur, portu Dalian i Kolei Południowomandżurskiej oraz przedstawił własną propozycję regulacji działalności chińsko-japońskiego towarzystwa gospodarczego, prowincji Shandong i rozwoju kolejnictwa w Mandżurii. Japońskie żądania zorientowane w obszarze politycznego ubezwłasnowolnienia Chin, tzw. pakiet piąty ${ }^{17}$, Pekin odrzucił w całości, odmawiając przy tym jakichkolwiek negocjacji18.

Wobec braku aktywnego przeciwdziałania ze strony Rosji, Wielkiej Brytanii i Stanów Zjednoczonych 26 kwietnia 1915 r. rząd japoński, dostrzegając wzrost nastrojów antyjapońskich w Chinach, przedstawił ponownie Pekinowi zmodyfikowane i złagodzone nieco żądania, podejmując jednocześnie dyplomatyczne naciski na jak najszybsze zawarcie porozumienia. 7 maja Japonia wystosowała do rządu chińskiego ultimatum, w którym wyznaczono 9 maja jako nieprzekraczalny termin wydania zadowalającej odpowiedzi. Do 25 maja rząd Iwana Shikaia prowadził dyplomatyczne zabiegi, w końcu jednak uległ; podpisano chińsko-japońskie traktaty i porozumienia, uwzględniające wszystkie najważniejsze żądania Japonii, z wyjątkiem roszczeń piątej grupy ${ }^{19}$.

17 Pakiet piąty „21 żądan” zorientowany był na żądaniach ogólnopolitycznych, zgodnie z którymi „Rząd chiński ma »zapraszać« Japończyków na doradców w sprawach politycznych, finansowych i wojskowych; organa policji w najważniejszych ośrodkach Chin mają być kierowane wspólnie przez Japończyków i Chińczyków. Chiny mają nabywać w Japonii około 50\% uzbrojenia, tworzyć arsenały japońsko-chińskie, przyznać Japonii prawo budowy linii kolejowych w Chinach Środkowych, nie budować linii kolejowych i portów bez wiedzy Japonii w prowincji Fujian i innych". Ibidem, s. 303.

18 Ibidem, s. 304.

19 Ibidem, s. 305-306. 
Rysunek 1. Karykatura z końca XIX w. przedstawiająca „dzielenie” Chin między obce mocarstwa: Wielką Brytanię, Niemcy, Rosję, Francję i Japonię

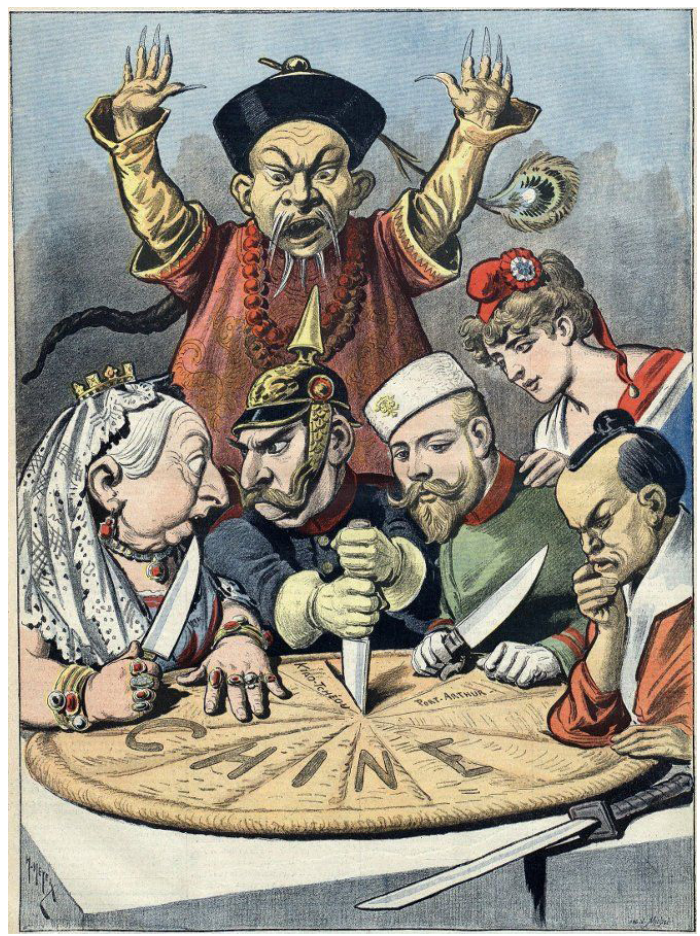

Źródło: https://histmag.org/grafika/articles4/xinhai/karykatura.jpg [dostęp: 6.04.2019].

Sytuacja na froncie europejskim I wojny światowej była szczególnie wyczerpująca dla Rosji i wymagała znacznego zaangażowania sił i środków. Z tego też powodu rząd carski był dalece zainteresowany dostawami broni z Japonii i utrzymaniem poprawnych stosunków na dalekowschodnich granicach. W końcu 1915 r. rządy Rosji i Japonii rozpoczęły rokowania w sprawie zawarcia traktatu sojuszniczego. Po długich negocjacjach, 3 lipca 1916 r. podpisano układ, zgodnie z którym 
strony zobowiązywały się do nieprzystępowania do jakichkolwiek sojuszów, które skierowane byłyby przeciwko interesom strony układającej się, a w wypadku niebezpieczeństwa ze strony innych państw do uzgadniania i podejmowania kroków w celu wspólnej obrony interesów na Dalekim Wschodzie. Tajna część traktatu stanowiła: „Obie wysokie układające się strony, uznając, że ich żywotne interesy wymagają, aby Chiny nie dostały się pod władzę jakiegokolwiek bądź innego, wrogiego Rosji lub Japonii państwa, ustanowią szczere i przyjacielskie stosunki za każdym razem, gdy sytuacja będzie tego wymagała, i uzgodnią odpowiednio kroki, aby zapobiec podobnej sytuacji”20. Aby zneutralizować ewentualne sprzeciwy Wielkiej Brytanii i Stanów Zjednoczonych, dyplomacja Rosji i Japonii dała gwarancje utrzymania zasady "otwartych drzwi” w Chinach. Japonia osiągnęła założony cel: niezaangażowana aktywnie w wojnę światową mogła rozszerzać swą agresję w Chinach, nie obawiając się zagrożenia ze strony północnego sąsiada, który stał się jej sojusznikiem.

Umocnienie pozycji Japonii w Chinach wspierać miała ofensywa dyplomatyczna Tokio wobec Wielkiej Brytanii, Francji i Rosji prowadzona w okresie od 16 lutego do 1 marca 1917 r., w wyniku której państwa te zobowiązały się do udzielenia poparcia podczas konferencji pokojowej dla japońskich roszczeń „w sprawie rozporządzania prawami Niemiec w Shandongu i na byłych niemieckich wyspach na północ od równika"21. Także Sta-

20 Ibidem.

21 M. Sładkowski, op.cit., s. 161. W tekście tajnego memorandum skierowanego przez brytyjskiego ambasadora w Tokio do wicehrabiego Ichiro Motono ministra spraw zagranicznych Japonii stwierdzano m.in.: „Rząd Jego Królewskiej Mości przychyla się z przyjemnością do życzenia Japońskiego Rządu co do dania zapewnienia, iż będzie popierał żądania Japonii w przedmiocie rozporządzenia niemieckiemi prawami do Szantungu i posiadłościami w wyspach na północ od równika przy sposobności konferencji pokojowej, rozumiejąc, że Japoński Rząd przy ewentualnych pokojowych układach traktować będzie w tym samym duchu żądania Wielkiej Brytanii 
ny Zjednoczone, po wypowiedzeniu wojny Niemcom 6 kwietnia 1917 r. ${ }^{22}$ zmieniły zdecydowanie oficjalne stanowisko wobec polityki Japonii w Chinach. 2 listopada 1917 r. za cenę utrzymania przez Japonię polityki „otwartych drzwi” zawarte zostało porozumienie Lansing-Ishi, w którym doktryna ta została potwierdzona wraz z klauzulą konieczności zachowania „niepodległości i terytorialnej integralności Chin”. Japonia zobowiązała się respektować prawa handlu innych państw z Chinami oraz nie naruszać praw handlowych przyznanych przez rząd chiński. W zamian Waszyngton zaakceptował oświadczenie: „Rządy Stanów Zjednoczonych i Japonii stoją na stanowisku, że sąsiedztwo terytorialne stwarza specjalne stosunki pomiędzy państwami, wobec czego rząd Stanów Zjednoczonych uznaje specjalne interesy Japonii w Chinach, szczególnie w tej części, z którą graniczą posiadłości japońskie"23.

Sytuacja polityczna na Dalekim Wschodzie zmieniła się nie tylko w wyniku przystąpienia USA do wojny, lecz przede wszystkim w związku z wybuchem rewolucji w Rosji ${ }^{24}$, upadkiem władzy carskiej i przejęciu władzy przez bolszewików oraz przystąpieniem Chin do wojny po stronie ententy ${ }^{25}$. W grudniu 1917 r. wojska chińskie rozpoczęły przejmowanie Kolei

co do niemieckich wysp na południe od równika”. Szerzej: W. Wilson, op.cit., s. 76-77.

22 Udział USA w I wojnie światowej szeroko opisano w: G.C. Marshall, Memoirs of My Services in the World War 1917-1918, Boston 1976, s. 268; J.S. Levy, The first Word War: causes, concequences, and controversies, https://fas-polisci.rutgers.edu [dostęp: 5.07.2019]; H. Kissinger, Dyplomacja, Warszawa 2002, s. 177-284.

23 Z. Góralczyk, Komunistyczna Partia Chin a Stany Zjednoczone (lipiec 1921-czerwiec 1950), Warszawa 1981, s. 50-51.

24 Por. I.R. Saveliev, Y.S. Pestushko, op.cit.

2514 marca 1917 r. pekiński rząd Duan Qirui zerwał stosunki dyplomatyczne z Niemcami, lecz wypowiedzenie przez Chiny wojny Niemcom nastąpiło dopiero 14 sierpnia tego roku po wielu wewnętrznych perturbacjach będących konsekwencją ówczesnego układu sił politycznych w Chinach. Szerzej w: G. Jefimow, op.cit., s. 194-195. 
Wschodniochińskiej, a w styczniu 1918 r. rząd chiński przejął kontrolę nad jej wschodnim odcinkiem. 16 stycznia 1918 r. rząd Duan Qirui’a podpisał konwencję o wysłaniu chińskich oddziałów wojskowych pod dowództwem japońskim ${ }^{26}$ do walki na obszarach Syberii, w ramach koalicji aliantów, której głównym zadaniem była ochrona zaopatrzenia armii carskiej - sprzymierzeńca $w$ wojnie przeciwko Niemcom ${ }^{27}$ i rozprzestrzeniającemu się bolszewizmowi. 24 czerwca 1918 r. została także podpisana deklaracja wysłania chińskiego wojska do Władywostoku w ramach 12. dywizji japońskiej ${ }^{28}$. W przekazanej opinii publicznej informacji podano, że powodem działań chińskiego rządu miała być pomoc Rosji w walce $\mathrm{z}$ zagrożeniem niemieckim i obrona korpusu czechosłowackiego. Konwencja z września 1918 r. precyzowała warunki działań wojsk chińskich na terytorium Zabajkala i obwodzie amurskim. Jednak zobowiązania rządu Duan Qirui spotkały się ze społecznym sprzeciwem, zaś chińskie wojska nie otrzymały właściwego wsparcia logistycznego i zbrojeniowego, co wpłynęło w 1919 r. na decyzję chińskiego rządu o wycofaniu się z dalszego udziału w syberyjskiej kampanii ${ }^{29}$.

Przystąpienie do wojny po stronie ententy nie przyniosło Chinom istotnych korzyści. Chiński rząd uzyskał jedynie od-

26 Szerzej w: W. Materski, Bolszewicy i samuraje. Walka dyplomatyczna i zbrojna o rosyjski Daleki Wschód (1917-1925), Warszawa 1990, s. 257.

27 Por. T. Dmochowski, Interwencja mocarstw na Syberii i Dalekim Wschodzie (1918-1922), Toruń 2000, s. 346; I. Plesiewicz-Świerczyńska, Wyktadnie ideologiczne stosunków japońsko-amerykańskich w latach 1853-1941 oraz ich implementacja polityczna, praca doktorska, Łódź 2017, https://kipdf.com/queue/uniwersytet-odzki-wydzia-studiow-midzynarodowych-i-politologicznych-izabela-ples_5b35197b097c47886d8b4b18.html [dostęp: 20.08.2019].

28 Szerzej w: J. Polit, Japonia wobec rewolucji bolszewickiej $w$ Rosji, 1917-1922, „Dzieje Najnowsze” 2007, r. XLIX, nr 4, s. 51-73; T. Dmochowski, Rewolucja 1917 r. w strefie wywtaszczonej kolei wschodniochińskiej w Harbinie, „Gdańskie Studia Azji Wschodniej” 2015, nr 8, s. 101-102.

29 M. Pietraszak, W. Dacyszen, Regionalny aspekt historii stosunków rosyjsko-chińskich, Łódź 2012, s. 61-62. 
roczenie na pięć lat spłatę części kontrybucji „bokserskiej”30, narzuconej Chinom w 1901 r., podniesienie do 5\% opłat celnych. W zamian Chiny wyekspediowały do Europy i na Bliski Wschód ok. 100 tys. robotników przeznaczonych do budowy i utrzymania frontowej infrastruktury - głównie okopów i umocnień (wskazuje się, że ok. 2 tys. z nich poległo, zaś ok. 500 zginęło w trakcie podróży morskiej do Europy ${ }^{31}$ ) oraz dostarczania rekruta dla japońskich wojsk operujących na Syberii ${ }^{32}$, przy czym liczebność zorganizowanego korpusu chińskich oddziałów szacuje się na 100 tys. żołnierzy ${ }^{33}$.

Ogłoszone przez prezydenta Stanów Zjednoczonych Woodrow Wilsona „14 punktów” stanowiące podstawę konstrukcji nowego systemu i stosunków politycznych w międzynarodowym oraz deklaracje dotyczące przyszłości Chin odebrano w Chinach z wielką nadzieją na uregulowanie problemów związanych z autonomią terytorialną Państwa Środka ${ }^{34}$. Wśród 14 punktów emocje Chińczyków budziły następujące: „5. Swobodne, szczere i zupełnie bezstronne załatwienie wszystkich pretensji kolonialnych, oparte na ścisłym przestrzeganiu zasady, że przy rozstrzyganiu wszystkich tych problemów zwierzchnictwa interesy ludności miejscowej będą ważyły tyleż, co słusz-

30 Szerzej: S.L. Tychwinski (red.), op.cit., s. 385-412.

31 J. Polit, Wojny chińskich warlordów 1916-1928, Zabrze-Tarnowskie Góry 2017, s. 58.

32 Por. M.T. Mencel, Chińska Republika Ludowa jako wspótczesny podmiot środowiska międzynarodowego, t. I: Uwarunkowania, Toruń 2016, s. $275-276$.

33 M. Sładkowski, Pierwsza wojna światowa i Daleki Wschód (1914-1918), [w:] Historia polityczna Dalekiego Wschodu od końca XVI $w$ do 1945 r., red. J. Żukow, M. Sładkowski, A. Dubinski, tłum. H. Jaźwińska, Warszawa 1981, s. 319.

34 Por. P. Sokala, Liga Narodów - globalny diler zasad i wyjątków? Historyczne znaczenie organizacji w perspektywie historii Chin, [w:] Liga narodów wybranych, red. M. Florian Gawrycki, A. Bógdał-Brzezińska, Warszawa 2010, s. 51-52. 
ne pretensje rządu, którego tytuł ma być przedmiotem decyzji” oraz „14. Utworzenie Ligi Narodów o specjalnym statusie, w celu udzielenia wszystkim państwom, zarówno wielkim, jak i małym, wzajemnych gwarancji niezależności politycznej i integralności terytorialnej”35. Budujące pozytywne reakcje były także inne spontaniczne wypowiedzi amerykańskiego prezydenta, w których jednoznacznie wskazywał, iż Japonia winna oddać prawa do Shandongu, z zachowaniem praw do prowadzenia przedsięwzięć gospodarczych ${ }^{36}$. Jeszcze w styczniu 1918 r. podczas kongresu Związków Zawodowych twierdził: „Co się tyczy niemieckich kolonii, oświadczyłem kilkakrotnie, że zostały one do dyspozycji konferencji, której decyzje muszą uwzględniać przede wszystkim życzenia i interesy tubylczych mieszkańców tych kolonii" ${ }^{37}$. Wilson wielokrotnie deklarował chęć amerykańskiej pomocy Chinom jako „przyjaciel i wzorzec”, wyrażając także obawy jakie może nieść nadmierny rozwój potencjału Japonii dla utrzymania porządku i pokoju na Dalekim Wschodzie ${ }^{38}$.

Także deklaracje Brytyjczyków wzbudzały niekiedy pozytywne reakcje chińskiego społeczeństwa, nieświadomego wówczas politycznych uzgodnień zawartych w tajnych traktatach z Japonią mających zapewnić bezpieczeństwo ich ekonomicznych interesów, zwłaszcza w stylu: „My pragniemy widzieć Chiny zjednoczone i kwitnące oraz nabywające maksymalną ilość brytyjskich towarów wysokiej jakości; Japonia

35 I.I. Minc, Zwycięstwo koalicji nad Niemcami i ich sprzymierzeńcami, [w:] Historia dyplomacji 1914-1939, t. III, red. A.A. Gromyko et al., Warszawa 1973, s. 132-133; E. Bendiner, Czas aniołów. Tragikomiczna historia Ligi Narodów, tłum. J. Okopień, Warszawa 1981, s. 82, 87.

36 D. Mierzejewski, Wyzwania chińskiej dyplomacji u progu ery republikańskiej, „Azja-Pacyfik” 2011, t. XIV, s. 147.

37 W. Wilson, op.cit., s. 242.

38 M. MacMillan, Paryż 1919. Sześć miesięcy, które zmienity świat: konferencja pokojowa w Paryżu w 1919 roku i próba zakończenia wojny, Oświęcim 2018, s. 323-324. 
nie pragnie zbyt zjednoczonych oraz zbyt kwitnących Chin"39. Zagrożenia integralności Republiki Chin dostrzegano głównie ze strony agresywnie nastawionej Japonii.

W warunkach skomplikowanych stosunków międzynarodowych na obrady konferencji pokojowej w Paryżu udała się chińska delegacja reprezentująca zwaśnione rządy Chin Północnych i Południowych. Na jej czele stanął ówczesny minister spraw zagranicznych rządu pekińskiego Lu Zhengxiang, który w 1915 r. podpisał w imieniu chińskiego rządu układ z Japonią osadzony na założeniach „21 żądań” i układał się w Tokio jeszcze przed wyjazdem delegacji do Paryża ${ }^{40}$. Jednak główną postacią chińskiej delegacji był Wellington $\mathrm{Ku}$, poseł Chin w Stanach Zjednoczonych, blisko współpracujący z prezydentem Woodrow Wilsonem. Zespół uzupełniali jeszcze ambasadorzy Chin w Wielkiej Brytanii i Belgii oraz dwaj przedstawiciele rządu południowego. Podczas konferencji wersalskiej chińska delegacja miała przedstawić następujące sprawy: 1. Zwrot Chinom Shandongu i unieważnienie traktatów z 1915 r. zawartych z Japonią na podstawie „21 żądań”; 2. Likwidacja wszelkich specjalnych praw i przywilejów państw imperialistycznych w Chinach: a) likwidację stref wpływów, b) ewakuację z terytorium chińskiego wojsk obcych i policji, c) likwidację urzędów pocztowych i stacji radiowych państw obcych, d) zrzeczenie się mocarstw jurysdykcji konsularnej, e) zwrot Chinom „dzierżawionych” terytoriów i wydzielonych osiedli, f) przywrócenie Chinom autonomii celnej; 3. Likwidacja wszystkich praw politycznych i ekonomicznych Niemiec i Austro-Węgier w Chinach $^{41}$. s. 105.

39 J. Polit, Mocarstwa wobec rewolucji Xinhai, „Azja-Pacyfik” 2011, t. XIV,

40 Margaret MacMillan, op.cit., s. 325.

41 G. Jefimow, Wielka Socjalistyczna Rewolucja Październikowa a Daleki Wschód. Konferencja waszyngtońska, [w:] Historia polityczna Dalekiego 
Chińczycy nie uzyskali zgody na wprowadzenie przygotowanych zagadnień pod obrady konferencji. 27 stycznia $1919 \mathrm{r}$. do programu włączono jedynie kwestię Shandongu, lecz ostateczne rozstrzygnięcie zapadło dopiero w kwietniu. Do tego czasu Japończycy prowadzili szereg zakulisowych rozmów, zwłaszcza z Lloydem George’em, Balfourem, Clemenceau i Pichonem, przekonując ich do swoich racji. 21 kwietnia szef japońskiej delegacji postawił Wilsonowi i Lansingowi żądanie zamknięcia kwestii Shandongu jeszcze przed przyjęciem traktatu pokojowego z Niemcami, ostrzegając przed ewentualnymi działaniami odwetowymi w przypadku gdyby decyzje nie były korzystne dla strony chińskiej. 22 kwietnia szef japońskiej delegacji Nobuaki Makino (1861-1949) ${ }^{42}$ powtórzył listę japońskich roszczeń i przypomniał treść tajnych układów. Przez kolejnych kilka dni trwały dyplomatyczne „szachy”, zakończone całkowitą porażką chińskiej delegacji, którą zapoznano ze szczegółami układu 30 kwietnia. Chiny straciły Shandong kolebkę chińskiej cywilizacji, miejsce urodzenia Konfucjusza i Mencjusza, chińską „Ziemię Świętą" liczącą wówczas $36 \mathrm{mln}$ mieszkańców ${ }^{43}$. Decyzją Stanów Zjednoczonych, Wielkiej Brytanii i Francji w artykułach 156-158 traktatu wersalskiego ustalono prawa Japonii do Shandongu, linii kolejowych i kopalin w tym regionie oraz wszelkie prawa i przywileje, które wcześniej otrzymały Niemcy od Chin, a także wszelkie poniemieckie mienie ruchome i nieruchome, uprawnienia dotyczące dzierżawy gruntów, funduszy itp., przy czym Japonia utrzymywała wszelkie prawa wcześniej uzgodnione z Chinami. Jakby

Wschodu od końca XVI w do 1945 r., red. J. Żukow, M. Sładkowski, A. Dubinski, tłum. H. Jaźwińska, Warszawa 1981, s. 334.

42 Nominalnie szefem japońskiej delegacji uczestniczącej w pokojowej konferencji paryskiej był Kinmochi Saionji (1849-1940), doradca cesarza, który prawdopodobnie ze względu na stan zdrowia usunął się na drugi plan. https://pl.wikipedia.org/wiki/Kinmochi_Saionji [dostęp: 15.08.2019].

43 Margaret MacMillan, op.cit., s. 327-332. 
ironicznie, w art. 131 traktatu nałożono na Niemcy obowiązek zwrotu Chinom przyrządów astronomicznych zagrabionych w 1900 r. w Pekinie $^{44}$.

Chiny nigdy nie zaakceptowały postanowień traktatu wersalskiego; pod naciskiem chińskiego społeczeństwa rząd w Pekinie wydał chińskiej delegacji polecenie odmowy jego podpisania i opuszczenia konferencji, lecz mimo tego zostały członkiem Ligi Narodów, a to za sprawą podpisania i ratyfikowania traktatu z Saint Germain, który zawierał w swej treści postanowienia Paktu Ligi Narodów, zaś Japonii przyznano ważne miejsce jako stałego członka Rady Ligi ${ }^{45}$. Słuszna wydaje się ocena zachowania mocarstw wobec ówczesnych Chin: „Pomiędzy państwami alianckimi (...) obowiązywało niewypowiedziane porozumienie co do faktu, że zasada samostanowienia, jak zresztą każda inna z zasad dyskutowanych na paryskiej konferencji pokojowej, będzie odczytywana w określonym kontekście, że jej »uniwersalne « zastosowanie będzie się ograniczać jedynie do ram zakreślonych przez wielkie mocarstwa decydujące o zasadach gry. Prawo samostanowienia miało więc dotyczyć narodów podległych imperiom pokonanym, wielkim przegranym I wojny światowej, i to tylko na obszarze kontynentu europejskiego. Niemieckie kolonie stanowiły już pulę łupów do podziału. (...) Woodrow Wilson był zdeklarowanym rasistą (...). W jego intencji sformułowanie zasady samostanowienia nie miało zmierzać do rzeczywistego przyznania wolności narodom kolonialny, ale do darowania jej zniewolonym białym nacjom europejskim i osłabienia pozycji starych imperiów kolonialnych"46. Hipokryzja ówczesnych mocarstw, zwłaszcza Stanów Zjednoczonych, wyrażała

44 G. Jefimow, Wielka Socjalistyczna..., op.cit., s. 338.

45 S. Sierpowski, Narodziny Ligi Narodów. Powstanie, organizacja i zasady działania, Poznań 1984, s. 140.

46 Por. P. Sokala, op.cit., s. 62. 
się w tworzeniu reżimów prawnych wyłącznie dla własnego interesu, powstających w idealistycznych wizjach powszechnego ładu, pokoju i samostanowienia społeczeństw. Przypadek Chin wyraźnie ujawnia słuszność tej tezy i nie zmienia tego fakt, iż Stany Zjednoczone nie przyjęły paktu Ligi Narodów, przyczyniając się w istotnej mierze do politycznych następstw tej decyzji skutkujących w środowisku międzynarodowym ${ }^{47}$.

Kwestia Shandongu znalazła swój finał podczas konferencji waszyngtońskiej w 1922 r., poświęconej regulacji zbrojeń morskich $^{48}$. Chiny uzyskały autonomię nad utraconą prowincją, zaś linia kolejowa eksploatowana przez Japończyków miała być Chinom odsprzedana ${ }^{49} .4$ lutego $1922 \mathrm{r}$. podpisane zostało dwustronne chińsko-japońskie porozumienie, zgodnie z którym Japonia zobowiązała się do zwrotu w terminie 6 miesięcy terytorium Shandongu i ewakuowania wojska. Jako rekompensatę za majątek kolei Jiaozhou-Cinan Chiny w ciągu 15 lat miały wypłacać Japonii $32 \mathrm{mln}$ jenów w srebrze. Kopaliny miały być wydobywane przez japońsko-chińskie konsorcjum, zaś Jiaozhou miał zostać otwarty jako port traktatowy dla handlu zagranicznego. Postanowiono także, iż do czasu spłaty całości zobowiązań szereg ważnych stanowisk zajmować będą Japończycy. Chińsko-japońska ugoda umożliwiała wejście do Shandongu amerykańskiego kapitału, wzmacniając ekonomiczną pozycję w regionie, zaś w kategoriach politycznych, Stany Zjednoczone doprowadziły do osłabienia wpływów Japonii na kontynencie ${ }^{50}$. Jednak w dalszej perspektywie, rozbudziła

47 Ocenę działalności Woodrow Wilsona przedstawiono w: P. Łukasik, Impuls Wilsona - Stany Zjednoczone w I wojnie światowej, „Ante Portas Studia nad Bezpieczeństwem" 2015, nr 1, s. 45-67.

48 Szerzej: W. Rojek, Spory o wtadanie morzem. Polityczno-dyplomatyczne aspekty zbrojeń morskich w okresie międzywojennym 1919-1939, Kraków 1994, s. 55-91.
49 Margaret MacMillan, op.cit., s. 327-335.
50 G. Jefimow, Wielka Socjalistyczna..., op.cit., s. 364-370. 
w Japonii nastroje, których upust zorientował się na podjęciu działań wojennych przeciwko Chinom w 1937 r. ${ }^{51}$

\section{Sytuacja polityczna Republiki Chin po obaleniu rządów cesarskich}

Wraz z pierwszą wojną opiumową w latach 1839-1842 rozpoczął się okres upadku mandżurskiej dynastii Qing rządzącej Chinami nieprzerwanie od 1644 r. ${ }^{52}$ Upadkowi rządów feudalnych towarzyszył rozkład systemu stosunków społecznych osadzonych na tradycji konfucjańskiej - eklektycznego połączenia taoizmu, buddyzmu i ortodoksyjnego konfucjani$\mathrm{zmu}^{53}$ - ukształtowanej na przełomie wieków starej i nowej ery. Feudalny system Chin wykazywał znaczne opóźnienie rozwojowe w stosunku do Zachodu we wszystkich dziedzinach: gospodarce narodowej, technologii produkcyjnej, a zwłaszcza wojskowej, postępu w obszarach ideologii oddziałujących na postęp społeczno-gospodarczy państwa. Paradoksalnie jednak wraz z rozwojem wymuszonych stosunków gospodarczych Chin z Zachodem, dla części chińskiego społeczeństwa otwierały się szerokie przestrzenie do przejmowania zachodnich wzorców. Konsekwencją wszystkich negatywnych zjawisk społeczno-politycznych i gospodarczych był wybuch rewolucji o cechach: (I) rewolucji narodowej o podłożu antymadżurskim; (II) rewolucji demokratycznej, dążącej do zmian

51 Szerzej: M.T. Mencel, Chińska Republika Ludowa jako współczesny podmiot środowiska międzynarodowego, t. II: Wektory, Toruń 2016, s. 573-587 .

52 Szerzej: idem, Chińska Republika Ludowa jako współczesny podmiot środowiska międzynarodowego, t. I: Uwarunkowania..., s. 100-110.

53 Idem, Chińska Republika Ludowa jako wspótczesny podmiot środowiska międzynarodowego, t. III: Rozważania o rzeczywistości, Toruń 2016, s. 863-894. 
systemowych osadzonych na zachodnich wzorcach demokratycznych; (III) rewolucji społecznej, której celem było wyrównanie powszechnych praw do ziemi i obrona praw pracowni$\mathrm{Czych}^{54}$; (IV) powstawanie organizacji politycznych.

Jednak rewolucja Xinhai ${ }^{55}$, która w 1912 r. zmusiła do abdykacji ostatniego cesarza Qing ${ }^{56}$ i doprowadziła do proklamowania Republiki Chińskiej ${ }^{57}$, wyboru pierwszego (tymczasowego) prezydenta Sun Yat-sena ${ }^{58}$, utworzenia pierwszego parlamentu ${ }^{59}$, ustanowienia pierwszej konstytucji ${ }^{60}$, nie była na tyle zorganizowanym ruchem, by zaprowadzić trwałe zmiany społeczno-polityczne w państwie. System gospodarczy państwa pozostał bez zmian, dominujące pozycje $\mathrm{w}$ dalszym ciągu zajmowała stara arystokracja i silna burżuazja. Pogłębił się podział oficjalnego ośrodka władzy między północą i południem Chin, a faktyczną władzę polityczną i gospodarczą przejęli militaryści dysponujący znaczącym potencjałem wojskowym w poszczególnych prowincjach kraju ${ }^{61}$. W Pekinie podejmowano kontrrewolucyjne próby

54 J. Bayer, W.J. Dziak, Historia polityczna Chin 1839-2014. Konspekt analityczny, Warszawa 2016, s. 107.

551911 r. w tradycyjnym chińskim kalendarzu nazywał się xinhai, zatem wydarzenia, które wówczas miały miejsce przeszły do historii jako Rewolucja Xinhai.

56 Cesarz Puyi abdykował 12 lutego 1912 r. J. Bayer, W. Dziak, Historia polityczna Chin 1839-2014. Kronika najważniejszych wydarzeń, Warszawa 2015, s. 84 .

57 Republikę Chin proklamowano 1 stycznia 1912 r. w Nankinie na mocy Deklaracji Tymczasowego Prezydenta Republiki Chin, lecz obejmowała jedynie południowe obszary kraju. Ibidem, s. 82.

58 Sun Yat-sen został wybrany na tymczasowego prezydenta Chin 29 grudnia 1911 r. podczas kongresu delegatów 17 prowincji w Nankinie. Ibidem, s. 81.

59 Pierwszy chiński parlament został powołany 28 stycznia $1912 \mathrm{r}$. Ibidem, s. 84.

60 Tymczasową Konstytucję Republiki Chin uchwalono 11 marca 1912 r. Ibidem, s. 85.

61 Szerzej: Jakub Polit, Wojny chińskich warlordów..., op.cit., s. 17-85. 
restauracji władzy cesarskiej ${ }^{62}$. Krajem wstrząsały bunty i rewolty. Militaryści, niczym w Epoce Walczących Królestw, prowadzili bezustanne ze sobą walki, wzmagające zapotrzebowanie na broń i rekruta ${ }^{63}$, eskalujące zatem rosnącymi roszczeniami podatkowymi wobec chińskiego społeczeństwa. Poszczególne ugrupowania militarystyczne wspierane były przez państwa imperialne, zwłaszcza Japonię, upatrujące w narastającym chaosie większych perspektyw na korzyści gospodarcze, łatwiejszego dostępu do chińskich zasobów i rynku. Sytuacja wewnętrzna Chin nie uległa zmianie po fiasku rządów Yuan Shikaia, zakończonych jego śmiercią w 1916 r. Nastąpił okres zażartej walki o przejęcie kontroli nad rządem centralnym w Pekinie, uznawanym przez obce mocarstwa, co pozwalało na zaciąganie pożyczek, chętnie udzielanych chińskim przywódcom w zamian za utrzymanie odpowiedniej koniunktury dla interesów politycznych i gospodarczych.

Pierwsze społeczne organizacje polityczne w Chinach zaczęły powstawać jeszcze w XIX w. i wiążą się z osobą Kang Youwei'a, który w kwietniu 1898 r. powołał pierwszą partię polityczną o charakterze europejskim - Stowarzyszenie Obrony Ojczyzny, zrzeszające zwolenników reform politycznych. Status nowej organizacji wskazywał na konieczność walki o integralność terytorialną Chin i bezpieczeństwo narodu, propagowania działalności reformatorskiej w dziedzinie polityki wewnętrznej i zagranicznej, upowszechniania wiedzy ekonomicznej oraz udzielania pomocy władzom cesarskim w sprawach administracyjnych. Pomimo przyjęcia wzorców

62 Próbę przewrotu monarchicznego podjął w 1915 r. Yuan Shikai, tymczasowy prezydent Chin, który przejął władzę po ustąpieniu Sun Yat-sena. Szerzej: S.L. Tychwinski (red.), op.cit., s. 628-634.

63 Ocenia się, że między 1912 a 1928 r. liczba żołnierzy w armiach chińskich wzrosła z pół miliona do dwóch milionów. Por. R. Sławiński, Yuan Shikai i rządy militarystów. Wyprawa północna i zjednoczenie kraju, [w:] Nowożytna historia Chin, red. idem, Kraków 2005, s. 126. 
zachodnich organizacji, Stowarzyszenie Kang Youwei’a wyrażało opinię o nadrzędnej roli konfucjańskich wzorców stosunków społeczno-politycznych, idealizując przy tym władzę cesarza, zaś działalność organizacji skierowana była głównie do gentry - wyższej warstwy społecznej ${ }^{64}$. Dostrzegając konieczność wprowadzenia zmian jako element polityki wewnętrznej ukierunkowanej na umacnianie władzy dynastii mandżurskiej, cesarz Guangxu zatwierdził program „Sto dni odnowy", którego realizacja trwała od 11 czerwca do 21 września 1898 r., wzorowany na japońskim programie „restauracji Meiji". W tym czasie ogłoszono czterdzieści cesarskich edyktów reformujących system społeczny i instytucjonalny Państwa Środka ${ }^{65}$. Najważniejsze z reform dotyczyły utworzenia rządowych resortów kierujących przemysłem górniczym, rolnictwem, przemysłem i handlem, koleją, produkcją maszyn parowych i obrabiarek, działalnością marketingową w obszarze handlu herbatą i jedwabiem, zarządzania i struktury wojska oraz systemu policyjnego ${ }^{66}$. Zmiany wprowadzono także w oświacie: odstąpiono od egzaminu polegającym na pisaniu wypracowań w stylu konfucjańskim, popieraniu włączania do programów szkolnych nauk „zachodnich”, propagowano szkolnictwo prywatne, popierano nauki techniczne i metodologię upraw rolnych i europejskiej agrotechniki, modernizacji sił zbrojnych. Obszar "nowych nauk” (współczesna problematyka polityczna i ekonomiczna) został zwolniony z systemu egzaminów państwowych. Powołano w Pekinie akademię medyczną. Obszarem reform była także komunikacja społeczna w zakresie propagowania wydawnictw prasy codziennej, czasopism,

\footnotetext{
64 S.L. Tychwinski (red.), op.cit., s. 350-352.

65 J. Bayer, W.J. Dziak, Historia polityczna Chin 1839-2014. Konspekt analityczny..., op.cit., s. 49-50.

66 J.K. Fairbank, Historia Chin. Nowe spojrzenie, tłum. T. Lechowska, Z. Słupski, Warszawa-Gdańsk 2003, s. 210.
} 
przekładów publikacji zagranicznych i utworzenie pierwszego organu prasowego administracji rządowej w Szanghaju. Podjęto decyzję o zniesieniu niektórych zbędnych instytucji administracyjnych i wojskowych oraz redukcji etatów urzędniczych, zaś urzędnikom wszystkich stopni zezwolono na bezpośrednie zwracanie się do cesarza z memoriałami lub skargami ${ }^{67}$.

We wrześniu 1898 r. proces reform został zahamowany w wyniku przewrotu zorganizowanego przez reakcyjne ugrupowanie Ci Xi - matki cesarza Guangxi, wspierane przez Yuan Shikai’a stojącego na czele Gwardii Cesarskiej. Główni inspiratorzy ruchu reform zostali aresztowani i straceni, cesarz Guangxi został uwięziony, zaś Kang Youwei zdołał uciec do Japonii $^{68}$. Ogłoszone cesarskimi edyktami reformy zostały zniesione; pierwszy ruch reformatorski w Chinach poniósł całkowitą klęskę, pozostawiając jedynie ideowe wzorce dla następców, których aktywność zaczęła ujawniać się po upływie kolejnej dekady.

Z krytyką polityki „samoumocnienia” propagowaną przez promandżurskie lobby, wystąpił Sun Yat-sen, który w środowisku emigracji chińskiej na Hawajach zorganizował w $1894 \mathrm{r}$. Związek Odrodzenia Chin, działającym pod hasłem „Wygnać barbarzyńskich Mandżurów, odrodzić Chiny, utworzyć zjednoczony rząd"69. Do Związku Odrodzenia Chin wstąpiło na Hawajach w ciągu dwóch miesięcy 126 osób - głównie drobni i średni kupcy, pracownicy biur prywatnych, subiekci handlowi, a w znacznej mniejszości przedstawiciele zamożnej burżuazji emigracyjnej. 27 stycznia 1895 r. powstał w Hongkongu główny Oddział Związku, kolejny w Kantonie, zrzeszając przedstawicieli stanu kupieckiego, a także lokalnej inteligencji. Latem

\footnotetext{
67 S.L. Tychwinski (red.), op.cit., s. 354-355.

68 W. Rodziński, Historia Chin, Wrocław-Warszawa-Kraków 1992, S. 510 .

69 M. Ławacz, Sun Yat-sen - życie i działalność, [w:] Sun Yat-sesn, Trzy zasady ludu, tłum. A. Łobacz, Warszawa 1914, s. 14.
} 
1895 r. oba oddziały skupiały kilkaset osób. Wśród głównych postulatów politycznych związku pierwszeństwo przyznawano konieczności likwidacji zasad powoływania na stanowiska państwowe, reformy systemu szkolenia wojska i oświaty publicznej oraz obowiązującego qingowskiego kodeksu praw. Zakładano, że osiągnięcie założonych celów, zwłaszcza obalenie dynastii mandżurskiej, możliwe jest jedynie na drodze rewolucji, w związku z czym przygotowywano w 1895 r. zbrojne wystąpienie w Kantonie. Jednak misternie przygotowywaną akcję udaremniły służby cesarskie. 70 osób aresztowano, kilku przywódców stracono, pozostali, w tym Sun Yat-sen, zmuszeni zostali do ucieczki zagranicę ${ }^{70}$.

Rozbicie przez obóz władzy mandżurskiej obu frakcji politycznych: „reformatorów” $\mathrm{i}$ „rewolucjonistów” "11, propagujących odmienne koncepcje przemian społeczno-politycznych w Chinach, nie doprowadziło do poprawy sytuacji w kraju. Ponownie wyzwoliły się siły rewolucyjne, tym razem na scenę wystąpiła tradycyjna organizacja Yihetuan ${ }^{72}$, tajne stowarzyszenie stanowiące odłam Białego Lotosu ${ }^{73}$, której główne siły stanowili chińscy chłopi, doprowadzeni uciskiem lokalnych warlordów i powodziami do rozpaczy z powodu głębokiego ubóstwa i głodu. Powstanie bokserów rozpoczęło się w 1898 r. w dwóch prowincjach Chin Północnych: Shandongu i Zhili i skierowane było głównie przeciwko agresywnej polityce państw imperialnych,

70 S.L. Tychwinski (red.), Historia nowożytna Chin, op.cit., s. 368-371.

71 T. Halik, Reformatorzy i rewolucjoniści, [w:] Nowożytna historia Chin, red. R. Sławiński, Kraków 2005, s. 107-115.

72 Yihetuan tłumaczy się jako Stowarzyszenie w imię Prawości i Harmonii. Praktyki z obszaru czarnej magii, rytuały religijne i uprawiane ćwiczenia sprawności ciała jako element samodoskonalenia członków tego stowarzyszenia przyczyniły się do upowszechnienia nazwy ruchu - powstanie bokserów. J. Bayer, W.J. Dziak, Historia polityczna Chin 1839-2014. Kronika..., op.cit., s. 57.

73 W. Rodziński, op.cit., s. 513. 
przejawiającej się ekspansją zagranicznego kapitału, zwłaszcza w obszarze budowy linii kolejowych w oparciu o udzielane kredyty i pod kierownictwem cudzoziemskich inżynierów. Na obszarach, przez które przechodziły budowane linie kolejowe następował upadek tradycyjnych dróg komunikacyjnych i środków transportu, pozbawiając źródeł dochodu właścicieli łodzi, ładowaczy, tragarzy, woźniców. Grunty przeznaczone pod budowę kolei zabierano chłopom, a nawet obszarnikom bez należnej rekompensaty ${ }^{74}$. Strach, że budowa kolei i telegrafów obraża lokalne bóstwa i duchy motywowały chłopów do wystąpień ${ }^{75}$. Do całokształtu przyczyn wybuchu rewolty Yihetuan przyczyniły się także nałożone na ludność dodatkowe podatki związane ze spłatą odszkodowań wojennych, zalew chińskiego rynku konkurencyjnymi towarami zagranicznymi eliminującymi lokalnych producentów, a zwłaszcza działalność zachodnich misjonarzy i chińskich chrześcijan ${ }^{76}$. Księżom katolickim zarzucano ingerencję w lokalny wymiar sprawiedliwości i narzucanie metod zarządzania państwem, realizując swoje cele polityczne przy wsparciu armii państw zachodnich. Chińczycy postrzegali intensywne działania związane z chrystianizacją jako ogromne zagrożenie dla wielowiekowej kultury konfucjańskiej oraz hierarchicznemu systemowi społeczno-politycznemu państwa. Nawracanie na chrześcijaństwo uznawano za naruszenie harmonii chińskiego społeczeństwa, zaś misje traktowano jako element polityki państw imperialistycznych ${ }^{77}$, wobec czego oddziały bokserów w pierwszej kolejności napadały na kościoły i burzyły domy Chińczyków chrześcijan, w następnej zaś niszczyły infra-

74 S.L. Tychwinski (red.), op.cit., s. 385-386.

75 W.S. Morton, Ch.M. Lewis, Chiny. Historia i kultura, tłum. B.S. Zemanek, Kraków 2007, s. 197.

76 T. Halik, Powstanie Yihetuan..., op.cit., s. 95.

77 Por. J. Konior SJ, Historia Kościoła w Chinach. Wyzwania, obawy i nadzieje (od nestorianizmu do czasów wspótczesnych, Kraków 2019, s. 83-93. 
strukturę kolejową i sieci telegraficzne. W trakcie rebelii zginęło ok. 250 misjonarzy i niemal 30 tys. chrześcijan ${ }^{78}$.

W maju $1900 \mathrm{r}$. oddziały Yihetuan zbliżyły się znacznie do Pekinu, zatem w obawie przed zagrożeniem dla zagranicznych przedstawicielstw państwa sojusznicze: Wielka Brytania, Francja, Włochy, Stany Zjednoczone, Rosja i Japonia przystąpiły do koncentrowania sił zbrojnych w okolicy Tianjinu ${ }^{79}$. 13-14 czerwca oddziały Yihetuan zajęły Pekin, wobec czego czy to z powodu obawy o własną skórę, czy też dostrzegając szansę wykorzystania ruchu bokserów do celów własnych wobec mocarstw imperialnych, 21 czerwca 1900 r. ogłoszono edykt cesarzowej Cixi wypowiadający im wojnę, w którym domagano się, by w ciągu 24 godzin ich przedstawiciele opuścili Pekin. W edykcie cesarskim zaakceptowano i poparto działalność Yihetuan, wzywając powstańców do udziału w odparciu zewnętrznego nieprzyjaciela. Bokserzy uzyskali legalny status i wsparcie w postaci zaprowiantowania, pieniędzy i starej broni, a wojska rządowe zostały zobowiązane do prowadzenia operacji wojennych wspólnie z bokserami ${ }^{80}$.

Jednak rewolucja nie miała żadnych szans wobec potęgi wojsk państw zachodnich, do których dołączyły jednostki Niemiec i Austro-Węgier. Dowodzenie wspólną armią interwencyjną powierzono niemieckiemu feldmarszałkowi Alfredowi von Waldersee. Już 13 sierpnia 1900 r. armia dotarła do Pekinu i następnego dnia padła stolica Chin. Kolejnego dnia cesarzowa Cixi potajemnie opuściła Pekin, z którego wcześniej uciekła większość przedstawicieli władz qingowskich. W wyższych dostojników dworu pozostał jedynie Li Hongzhang, któremu cesarzowa powierzyła zadanie ułożenia się z cudzoziemcami ${ }^{81}$.

\footnotetext{
78 Ibidem, s. 93.

79 T. Halik, Powstanie Yihetuan..., op.cit., s. 101-102.

80 S.L. Tychwinski (red.), op.cit., s. 403.

81 Witold Rodziński, op.cit., s. 524-525.
} 
7 września 1901 r. w siedzibie hiszpańskiego poselstwa w Pekinie został podpisany przez Li Hongzhanga oraz jedenaście państw (poza wymienionymi wyżej, także Belgię, Hiszpanię i Holandię) tzw. Protokół końcowy ${ }^{82}$, którego treść podważała suwerenność Chin, nakładając przy tym ogromną kontrybucję szacowaną na 333 mln USD, spłacaną przez czterdzieści lat z odsetkami równymi niemal kwocie głównej ${ }^{83}$. Wśród konsekwencji powstania Yihetuan dostrzega się, poza skutkami w wymiarze ekonomicznym, polityce międzynarodowej i całkowitej kompromitacji rządów dynastii mandżurskiej, także dalekosiężne skutki społeczne, zwłaszcza powszechną zmianę postawy chińskiego społeczeństwa wobec cudzoziemców z niechęci w nienawiść i wrogość, które wraz z rozwojem stosunków społeczno-politycznych, wzrostem świadomości ogólnospołecznej zaczęły kształtować postawy patriotyczne i nacjonalistyczne, a także wzrost orientacji prosowieckiej po $1917 \mathrm{r}$.

Kolejne dziesięć lat historii Chin, do upadku rządów dynastii Qing to „swoiste apogeum aktywności mocarstw obcych w Chinach", zaś w stosunkach wewnętrznych, można zdefiniować je jako okres chaosu, braku władzy centralnej i kształtowania pod wpływem czynników zewnętrznych nowych stosunków społeczno-gospodarczych. Rząd centralny w Pekinie całkowicie uzależnił się od wpływów zewnętrznych i zmuszony został do wprowadzenia reform zaniechanych przez cesarzową Cixi. W miejsce sinocentrycznego systemu trybutarnego regulującego relacje zewnętrzne Chin cesarskich wprowadzono instytucje dotychczas obce, wzorowane na modelu zachodnim, zwłaszcza japońskim. Podjęto próbę reorganizacji armii, oświaty, koncepcję trójpodziału władzy, utworzono Ministerstwo Spraw Zagranicznych, zmniejszono liczebność aparatu centralnego i tereno-

82 Tekst Protokołu końcowego czytaj w: J. Bayer, W.J. Dziak, Historia polityczna Chin 1839-2014. Konspekt analityczny..., op.cit., s. 61-63.

83 J.K. Fairbank, op.cit., s. 212. 
wego, zlikwidowano Wydział ds. Następcy Tronu oraz specjalne biuro rejestrujące notatki i inne materiały nadsyłane na ręce cesarza $^{84}$. Powstawały organizacje o charakterze zawodowym i branżowym, m.in. pierwsze izby handlowe, stowarzyszenia oświatowe, towarzystwa rolnicze, stowarzyszenia prawnicze i bankowe ${ }^{85}$. W wyniku reformy oświaty nastąpił znaczny wzrost liczby chińskich studentów podejmujących studia na uczelniach zagranicznych, zwłaszcza japońskich, gdzie w 1904 r. było ich 1,3 tys., w 1905 r. -8 tys. $^{86}$

Reformom towarzyszył wzrost korupcji aparatu biurokratycznego, którego przedstawiciele wykorzystywali wewnętrznych chaos do nielegalnego powiększania własnych dochodów, niejednokrotnie sabotując wykonywanie zarządzeń ministerstw oraz rządowego Komitetu Administracyjnego powołanego do wprowadzania reform. Na czele instytucji wdrażających reformy stanęły osoby wywodzące się z konserwatywnego środowiska cesarzowej, m.in. wielki książę Zheng mianowany został szefem nowo utworzonego Ministerstwa Spraw Zagranicznych i przewodniczącym Komitetu Reorganizacji Armii (Yuan Shikai został jego zastępcą), przy czym utrzymano w strukturach politycznych znaczenie cesarskiej Rady Wojennej, krewniak cesarzowej Cixi, Mandżur Cizhen trzymał tekę ministra handlu ${ }^{87}$. Projekt reformowania państwa przez konserwatywnych urzędników mandżurskich skazany był na niepowodzenie, zwłaszcza w związku z wzrostem niezadowolenia chińskiego społeczeństwa jakością rządów cesarskich oraz intensyfikacją polityki obozu rewolucjonistów. Władza dynastii Qing tak dalece straciła „mandat niebios", że nie pomogły jej nawet obietnice wprowadzenia, wzorem

\footnotetext{
84 S.L. Tychwinski, op.cit., s. 413-415.

85 J. Bayer, W.J. Dziak, Historia polityczna Chin 1839-2014. Konspekt analityczny..., op.cit., s. 73.

86 S.L. Tychwinski (red.), op.cit., s. 419.

87 Ibidem, s. 419.
} 
reform w Japonii, systemu monarchii konstytucyjnej i samorządów lokalnych oraz podjęte w latach 1906-1908 działania przygotowawcze. Reformy wymagały dodatkowego finansowania, których źródłem miały być nowe podatki handlowe i gruntowe, niezależnie od obowiązujących na podstawie dotychczasowych zasad feudalnych ${ }^{88}$.

Pod wpływem idei Sun Yat-sena, 18 września 1905 r. w Tokio odbył się zjazd założycielski rewolucyjnej organizacji politycznej, której nadano nazwę Zjednoczonej Rewolucyjnej Ligi Chińskiej. Przyjęto statut partii, wybrano Sun Yat-sena jej przewodniczącym, a w końcu roku rozpoczęto wydawanie „Gazety Ludowej”, propagującej polityczne cele ligi, osadzone na koncepcji Suna znanej jako „trzy zasady ludu”: nacjonalizm, władza ludu i dobrobyt ludu ${ }^{89}$. Zasada władzy ludu zorientowana była głównie na obalenie monarchii i utworzenie ustroju republikańsko-parlamentarnego. Zasada władzy ludu postulowała równoprawne uczestnictwo w sprawowaniu władzy wszystkich obywateli i ustanowienie instytucji Prezydenta wybieranego przez cały naród oraz wybór parlamentu w wyborach powszechnych, którego uprawnieniem byłoby stanowienie konstytucji, zgodnie z którą miałaby nastąpić znacząca decentralizacja władzy. Zasada dobrobytu ludu przewidywała głównie równe prawa do ziemi poprzez jej nacjonalizację oraz ograniczanie koncentracji własności ziemi. Sun opracował także szczegółowo zasady przyszłej konstytucji, w której monteskiuszowski trójpodział władzy uzupełniał instytucjami: kontrolującą i egzaminującą, wzorowanymi na organach funkcjonujących w Chinach feudalnych ${ }^{90}$.

88 Szerzej: J.K. Fairbank, op.cit., s. 226-228.

89 Szerzej w: Sun Yat-sen, Trzy zasady ludu, red. K. Gawlikowski, M. Ławacz, tłum. A. Łobacz, Warszawa 2014, s. 65-286; B. Góralczyk, Sun Yat-sen. Misjonarz rewolucji, Warszawa 2013, s. 112-115.

90 T. Halik, Reformatorzy i rewolucjoniści, [w:] Nowożytna historia Chin, red. R. Sławiński, Kraków 2005, s. 109. 
W listopadzie 1908 r. zmarł w niewyjaśnionych okolicznościach cesarz Kuang Su, zaś następnego dnia cesarzowa Cixi. Zgodnie z jej wola tron przypadł 2,5-letniemu Puyi - synowi księcia Zaifenga i wnukowi jej faworyta Ronglu ${ }^{91}$.

Nastroje rewolucyjne rozwijały się nie tylko wśród chłopskich mas. Objęły również chińską burżuazję, której potencjał wzrastał wraz z rozwojem przemysłowo-ekonomicznym rozwiniętych regionów nadmorskich i południowych, a także rozwijały się wewnątrz cesarskiej armii. Gdy w 1911 r. rząd Qingów, pod presją mocarstw zachodnich i Japonii, wydał dekret o nacjonalizacji kolei, który umożliwić miał rozwój inwestycji obcego kapitału w tym sektorze gospodarki oraz uzyskanie znacznych pożyczek dla rządu cesarskiego, całe Chiny ogarnęła fala sprzeciwu, ludność odmawiała płacenia podatków. W wielu miejscowościach kupcy przerwali handel, strajkowali studenci i robotnicy. Na 16 października 1911 r. przedstawiciele Zjednoczonej Ligi zaplanowali wybuch powstania w Wuhanie, które jednak zdemaskowano, wobec czego rozpoczęto działania już 10 października w Wuchangu. Dwa dni później w rękach powstańców był zarówno Wuchang, jak też Hanyang i Hankou ${ }^{92}$, głównie dzięki włączeniu się do działań zrewolucjonizowanej części armii qingowskiej. W końcu października rewolucja rozprzestrzeniła się na siedmiu prowincjach ${ }^{93}$. W ciągu dwóch miesięcy prowincje i miasta centralnych, południowych i północno-zachodnich Chin ogłosiły niezależność od Qingów i utworzyły luźną organizację pod wodzą oficerów wojskowych, członków Zjednoczonej Ligi i przywódców zgromadzeń prowincjonalnych, stworzonych przez Mandżu-

91 https://www.britannica.com/biography/Ronglu [dostęp: 17.09.2019].

92 Hankou, Wuchang i Hanyang do 1949 r. stanowiły odrębne miasta, które połączono w jedną aglomerację trójmiejską - Wuhan.

93 B. Góralczyk, Rewolucja Xinhai w chińskich dziejach, „Azja-Pacyfik” 2011, t. XIV, s. 18-20. 
rów w 1909 r., w ramach eksperymentu rządów konstytucyjnych ${ }^{94}$. Działania rewolucyjne odbywały się bez udziału Sun Yat-sena, który w tym czasie przebywał zagranicą (powrócił do Chin 25 grudnia 1911 r.), co nie przeszkodziło przedstawicielom piętnastu prowincji, które ogłosiły niezależność od władz cesarskich, dokonać 29 grudnia 1911 r. wyboru Suna na tymczasowego prezydenta Chin ${ }^{95}$.

Sytuację polityczną w Chinach wykorzystał Yuan Shikai stojący wówczas na czele cesarskiego rządu i qingowskich sił zbrojnych, który wynegocjował z rewolucjonistami abdykację cesarza w zamian za funkcję prezydenta Republiki Chińskiej do czasu ustanowienia konstytucji i powszechnych wyborów. Dzięki jego politycznemu sprytowi oraz dalekowzroczności i odpowiedzialności Sun Yat-sena, Chinom udało się uniknąć długiej i krwawej wojny domowej, chłopskich powstań i obcej interwencji ${ }^{96} .20$ grudnia 1911 r. przedstawiciele sześciu mocarstw wystąpiły z notami zarówno do strony rządowej, jak i do rewolucjonistów, w których wzywano do niezwłocznego zawarcia porozumienia, zwracając przy tym uwagę na zagrożenie własnych interesów. Działania dyplomatyczne wzmocniono koncentracją sił lądowych i morskich w rejonach Hankou, Nankinu, Szanghaju, Yantai (Czyfu), Kantonu i Inczon (Czemulpo). Do października 1912 r. stan liczebny obcych wojsk wzrósł do 10 tys. żołnierzy ${ }^{97}$. Kolejno następowały wydarzenia: 1 stycznia 1912 r. proklamowano powstanie Republiki Chińskiej, 12 lutego abdykację ogłosił cesarz Puyi, 13 lutego rezygnację złożył Sun Yat-sen, a 15 lutego Yuan Shikai został wybrany na tymczasowego prezydenta. 10 marca 1912 r. w Nankinie zwołano

94 W.S., Ch.M. Lewis, op.cit., s. 206.

95 T. Halik, Reformatorzy i rewolucjoniści..., op.cit., s. 110.

96 J.K. Fairbank, op.cit., s. 231.

97 G. Jefimow, Zarys nowożytnej i wspótczesnej historii Chin..., op.cit., s. $173-175$. 
Zgromadzenie Narodowe, które uchwaliło tymczasową konstytucję i powołało Yuan Shikaia na prezydenta republiki ${ }^{98}$.

Dalsza działalność Yuan Shikaia ujawniła jego faktyczne ambicje polityczne. Korzystając z wsparcia obcych mocarstw, opierając się na znacznych siłach militarnych przystąpił do wprowadzania rządów autorytarnych zmierzających do restauracji cesarstwa i systemu stosunków feudalnych. Rozpoczął od sukcesywnego odsuwania od władzy Guomindangu - Chińskiej Partii Narodowej, przemianowanej 25 sierpnia 1912 r. Ligi Związkowej ${ }^{99}$.

Wzmocnieniu pozycji Yuana sprzyjało zacieśnianie relacji z mocarstwami, głównie Japonią, a przyjęcie przez jego rząd zagranicznej pożyczki pomimo sprzeciwu parlamentu, doprowadziło do rozpoczęcia przez Guomindang wojny, która rozpoczęła się 12 lipca $1913 \mathrm{r}$. Do połowy grudnia siły Guomindangu zostały niemal całkowicie zlikwidowane, a przywódcy partii zbiegli z Chin do Japonii. 4 listopada Yuan Shikai zdelegalizował Guomindang, usuwając przy tym jego przedstawicieli z parlamentu, który z powodu utraty quorum utracił zdolność procedowania i przyjmowania ustaw. 1 stycznia 1914 r. Yuan Shikai rozwiązał parlament, a 26 stycznia powołał Radę Polityczną, której powierzył przygotowanie nowej konstytucji. Ogłoszona 1 maja 1914 r. wraz z ustawą o wyborze i sprawowaniu urzędu prezydenta dawała Yuan Shikaiowi szerokie uprawnienia polityczne, dożywotniego dyktatora. We wrześniu 1914 r. Yuan przywrócił kult konfucjański, a w listopadzie i grudniu 1915 r. przeprowadzono zebrania ludności ośrodków prowincjonalnych, celem przeprowadzenia konsultacji na temat systemu politycznego państwa. Większość miała wypowiedzieć się za ustanowieniem monarchii, wobec czego w grudniu władze oficjalnie zapowiedziały jej

\footnotetext{
98 T. Halik, Reformatorzy i rewolucjoniści..., op.cit., s. 111.

99 Ibidem.
} 
przywrócenie $^{100} .11$ grudnia Yuan Shikai wydał dekret o swoim wstąpieniu na tron i zmienił kolejny (1916) rok na pierwszy rok panowania Hungxien ${ }^{101}$. 23 grudnia, w Świątyni Nieba, Yuan w stroju wzorowanym na szatach cesarskich dokonał rytualnych ceremonii gwarantowanych wyłącznie chińskim cesarzom, lecz do koronacji nie doszło pod wpływem ruchów antymonarchistycznych wśród militarystów południowych, których prawdopodobieństwo poparcia zasugerowali politycy japońscy ${ }^{102}$.

Presja ruchu antymonarchistycznego przyczyniła się do zwołania przez Yuana Izby Ustawodawczej, która 22 marca 1916 r. podjęła uchwałę o zniesieniu monarchii i przywróceniu republiki. Mimo tego militaryści prowincji południowych domagali się ustąpienia Yuana ze wszystkich stanowisk i postawienia go poza prawem. Utworzyli Radę Wojenną, pełniącą funkcję rządu wojskowego Chin Południowych. Konflikt nie został rozwiązany pomimo nagłej śmierci Yuan Shikaia 6 czerwca 1916 r. ${ }^{103}$

Z poparciem wojskowej kliki Beiyang z Duan Qirui na czele, następcą Yuan Shikaia na stanowisku prezydenta Republiki Chińskiej został dotychczasowy wiceprezydent, najpierw przy Sun Yat-senie, następnie przy Yuanie, Li Yuanhong - persona bez zaplecza politycznego, lecz ze znanym nazwiskiem postrzeganym jako „przedstawiciel Południa”104. Wiceprezydentem został generał Feng Guozhang - numer 2 w klice Beiyang, lecz praktycznie całą władzę przejął Duan Qirui - despota i intrygant, wykształcony na Zachodzie, pod dowództwem Yuan Shikaia masakrował w Shandongu zbuntowanych bokserów,

100 G. Jefimow, Zarys nowożytnej i współczesnej historii Chin..., op.cit., s. 195.

\footnotetext{
101 A. Malicka (red.), op.cit., s. 33.

102 S.L. Tychwinski (red.), op.cit., s. 633.

103 Ibidem, s. 634-635.

104 J. Polit, Wojny chińskich warlordów..., op.cit., s. 47.
} 
w 1913 r. premier z powołania Yuana, a w latach 1912-1915 minister wojny ${ }^{105}$. Takiego układu warlordowie Południowych Chin i Sun Yat-sen nie mogli zaakceptować, zwłaszcza że Duan brutalnie występował przeciwko republikanom, stosując wobec nich przemoc i represje.

W wyniku sporu pomiędzy prezydentem a Duanem dotyczącego udziału Chin w I wojnie światowej, 23 maja Li Yuanhong zatwierdził dekret dymisjonujący Duana Qirui, lecz pod wpływem nacisków militarystów z wielu prowincji prezydent zmuszony został do podjęcia negocjacji z Duanem, zaś pośrednikiem w rokowaniach miał być generał Zhang Xun, zagorzały monarchista, zwolennik absolutystycznej władzy dynastycznej, wspierany przez imperialistów niemieckich dostawami broni i amunicji. W jego armii służyli w charakterze doradców niemieccy oficerowie. W związku z konfliktem między Li i Duanem imperialiści japońscy podjęli działania zmierzające do przeciągnięcia Zhanga na swoją stronę i wykorzystać go do wsparcia popieranego Duana. Zhang Xun wraz ze swoją armią przybył 8 czerwca 1917 r. na zaproszenie prezydenta do Tianjinu, po tym jak zadeklarował jego poparcie w zamian za wprowadzenie do konstytucji tzw. warunków abdykacji dworu qingowwskiego, uznanie konfucjanizmu za religię państwową oraz zgodę na zwiększenie liczebności jego armii o dwadzieścia batalionów. Li Yuanhong wyraził gotowość aprobaty tych warunków, żądając w zamian pomocy w pacyfikacji renegackich prowincji i podporządkowania wojsk zbuntowanych warlordów władzy centralnej. Pod presją Zhanga Li podjął decyzję o rozwiązaniu parlamentu ${ }^{106}$.

14 czerwca 1917 r. wojska Zhang Xuna wkroczyły do Peki$n u^{107}$, dokąd na zaproszenie Zhanga potajemnie powrócił tak-

\footnotetext{
105 Ibidem.

106 S.L. Tychwinski (red.), op.cit., s. 643-644.

107 J. Polit, Wojny chińskich warlordów..., op.cit., s. 55.
} 
że Kang Youwei oraz wielu starych dostojników qingowskich, a 1 lipca 11-letni Puyi został przez nich wezwany do objęcia cesarskiego tronu. Li Yuanhong odmówił akceptacji restauracji monarchii i schronił się przed rebeliantami w japońskim przedstawicielstwie, skąd prośbę o pomoc skierował do zdymisjonowanego wcześniej Duana Qirui, który wykorzystując sytuację, zwłaszcza dezaprobatę działań Zhanga ze strony innych generałów, niezwłocznie ogłosił się dowódcą Armii Ratowania Republiki, wydając rozkaz swoim wojskom marszu na Pekin ${ }^{108}$. Przez dwanaście dni „panowania” cesarskiej dynastii Qing spod pióra Kang Yuoweia wyszło dziewiętnaście cesarskich edyktów, w tym mianowanie Zhang Xuna „księciem Zhongyong”, gubernatorem generalnym stołecznej prowincji Zhili, naczelnym wodzem sił zbrojnych na całej Północy i jednym z sześciu oficjalnych doradców cesarza. Przywrócono także dynastyczny kalendarz, zaś systemowi politycznemu Chin zamierzano nadać charakter monarchii konstytucyjnej ${ }^{109}$.

12 lipca wojska Zhanga poddały się bez większego oporu, sam Zhang Xun schronił się w ambasadzie holenderskiej, Kang Youwei zbiegł do poselstwa amerykańskiego, młody Puyi powrócił do swych zajęć szkolnych, a przedstawiciele qingowskiego dworu wycofali się z całej afery. Duan Qirui ponownie objął tekę premiera, a obalonego prezydenta Li Yuanhonga zastąpił Feng Guozhang, także skonfliktowany z Duanem, zwłaszcza w kwestii siłowego zaprowadzenia centralizacji władzy, której zwolennikiem był premier. Tym razem sprzymierzeńcem Duana został inny warlord - Zhang Zuolin stojący na czele kliki z Fengtien (miastem zwanym także Mukden, a obecnie Shenyang) w Mandżurii. Do konfrontacji doszło w lutym 1918 r., w wyniku której

\footnotetext{
108 Witold Rodziński, op.cit., s. 582.

109 J. Polit, Wojny chińskich warlordów..., op.cit., s. 56.
} 
Feng Guozhang zmuszony został do ustąpienia z fotela prezydenckiego ${ }^{110}$.

Powrót Duana do władzy pogłębił konflikt między północą a południem. Południowi republikanie żądali przywrócenia porządku konstytucyjnego: przywrócenia parlamentu i powrotu prezydenta Li Yuanhonga oraz bezzwłocznej dymisji Duana. 14 sierpnia 1917 r. rząd Duana, wypełniając żądania państw ententy, wypowiedział Niemcom wojnę ${ }^{111}$, czego marnym efektem było jedynie uzyskanie pięcioletniego odroczenia spłaty bokserskiej kontrybucji.

6 września 1917 r. w Kantonie powstał konkurencyjny wobec Pekinu rząd z Sun Yat-senem, na czele którego głównym celem była obrona zasad ustalonych w republikańskiej konstytucji. Jednak związki Suna z południowymi warlordami znacznie ograniczały jego możliwości i swobodę działania. Utworzenie rządu Chin Południowych oznaczało całkowity rozłam kraju na dwa obozy i zapoczątkowało wojnę między nimi, której skutki dotknęły zwłaszcza prosty lud, w większości tkwiący jeszcze w feudalnych stosunkach społecznych, a zwłaszcza mentalnych. Kulminacyjny punkt defragmentacji politycznej Chin miał miejsce w 1924 r., co było efektem słabej władzy państwowej i braku ideologicznych podstaw funkcjonowania republiki. Od momentu jej proklamowania przez niespełna dziesięć lat fotel prezydenta Chin obsadzano 14-krotnie, powoływano 24 rządy, zwołano pięćparlamentów lub legislatur uzurpujących sobie ich funkcję, przy tym tylko jeden wybrany zgodnie z konstytucją, przyjęto cztery ustawy, którym usiłowano nadać uprawnienia ustawy zasadniczej ${ }^{112}$.

110 J. Fenby, Chiny. Upadek i narodziny wielkiej potęgi, tłum. J. Wąsiński, J. Wołk-Łaniewski, Kraków 2009, s. 223-224.

111 G. Jefimow, Zarys nowożytnej i wspótczesnej historii Chin..., op.cit., S. 200 .

112 J. Bayer, W.J. Dziak, Historia polityczna Chin 1839-2014. Konspekt analityczny..., s. 122. 


\section{Stan chińskiej gospodarki na początku XX wieku}

Chiny końca XIX i początku XX w. jako państwo półkolonialne pozostawały pod wpływem rosnącej penetracji obcych mocarstw. Pomimo przyjęcia po obaleniu feudalnych rządów dynastii mandżurskiej porządku politycznego opartego na republikańskiej konstytucji, w znakomitej większości nadal głęboko tkwiły w wielowiekowej tradycji feudalnej. Rozwój gospodarczy i wpływ zachodnich technologii zaznaczył się jedynie w portach traktatowych i ich okolicy oraz na terenach przybrzeżnych prowincji. Główną przyczyną takiego stanu rzeczy była słabo rozwinięta sieć dróg kolejowych. Pomimo że w 1910 r. wynosiła 7,5 tys. km, a w 1920 r. blisko 15 tys. km, to w dalszym ciągu nie odpowiadała na rosnące zapotrzebowanie chińskiej gospodarki. Znajdowała się głównie w Chinach Północnych i Północno-Wschodnich. Do chińskiego interioru nie docierały żadne bodźce gospodarki kapitalistycznej, pozostając olbrzymim i ludnym regionem zdominowanym prawie w $100 \%$ przez rolnictwo z jego feudalnymi stosunkami produkcji i półnaturalną autarkiczną gospodarką. Większość społeczeństwa pogrążona była w biedzie, pogłębianej wraz z presją wzrostu różnego rodzaju danin wprowadzanych przez władze centralne, jak również (a raczej przede wszystkim) przez lokalnych władców-warlordów, których utrzymanie licznych oddziałów wojsk wymagało ogromnych budżetów ${ }^{113}$. Konsekwencją było pogłębianie kryzysu agrarnego, spotęgowanie ucisku feudalno-obszarniczego i wzmożone zjawisko pauperyzacji chłopstwa. Coraz większe połacie ziemi leżały odłogiem: w 1914 r. wynosiły one 358 mln mu ${ }^{114}$; w 1915 r. - 404 mln mu; w 1916 r.

\footnotetext{
113 W. Rodziński, op.cit., s. 536-537.

114 Miara powierzchni $1 \mathrm{mu}=0,06 \mathrm{ha}$.
} 
- 390 mln mu; w 1917 r. -825 mln mu; w 1918 r. -849 mln mu. Znacznie obniżała się wydajność plonów ${ }^{115}$.

Ogromna powódź, która nawiedziła w 1917 r. kilka powiatów w prowincji Hunan pozbawiła miliony ludzi dachu nad głową i środków do życia. Całkowitemu zniszczeniu uległy zasiewy, padło bydło. W okresie od lipca 1917 r. do kwietnia następnego roku powodzie ogarnęły 103 powiaty, zatapiając obszar ponad 10 tys. $\mathrm{km}^{2}$. Zasiewy zniszczone zostały na obszarze 25 tys. mu, a 6,35 mln ludzi utraciło swe domostwa. Szereg prowincji ucierpiało wskutek inwazji szarańczy, suszy i innych klęsk żywiołowych. Ofiary katastrof pozostawały bez jakiegokolwiek wsparcia ze strony władz, które wykorzystywały sytuację do własnych haniebnych celów ${ }^{116}$.

Niemniej jednak w niektórych regionach Chin ujawniły się bodźce inicjujące rozwój kapitalistycznych form gospodarczych, przyczyniając się do wzrostu aktywności chińskiej burżuazji w inwestowaniu swoich kapitałów w różnego typu przedsiębiorstwach, zwłaszcza przemysłu lekkiego, głównie w tekstylnej jego gałęzi. Odnotowano także wzrost zaangażowania rodzimego kapitału w takich dziedzinach, jak młynarstwo, przemysł tytoniowy i zapałczany.

Wojna światowa zmusiła mocarstwa europejskie do znacznego ograniczenia aktywności gospodarczej w Chinach, ustępując miejsca i wzmocnienia pozycji Japonii i Stanów Zjednoczonych. Zmniejszenie importu towarów z Europy poprawiło bilans handlu zagranicznego Chin, który w 1914 r. wynosił 213 mln liangów srebra ${ }^{117}$, a w 1919 r. tylko 16,2 mln liangów. W 1900 r. istniały w Chinach tylko dwa zakłady przemysłu młynarskiego, w 1918 r. było ich już 86. W 1914 r. import mąki

\footnotetext{
115 S.L. Tychwinski (red.), op.cit., s. 656.

116 Szerzej: ibidem, s. 656-657.

1171 liang $=37,301 \mathrm{~g}$ srebra.
} 
pszennej przewyższał eksport o 2030 tys. tanów ${ }^{118}$, a w 1918 r. jej eksport przewyższał import o prawie 2 mln tanów ${ }^{119}$.

Największy wzrost zanotowano w obszarze przemysłu lekkiego. W latach 1913-1920 dzięki wsparciu kapitału narodowego zbudowano 675 zakładów w 23 gałęziach przemysłu lekkiego; najwyższe tempo rozwoju wykazywało włókiennictwo, co związane było ze znacznym zmniejszeniem importu przędzy bawełnianej. W 1913 r. w przemyśle włókienniczym było 484,19 tys. wrzecion, a w 1919 r. - 658,75 wrzecion. W 1913 r. eksport surowego jedwabiu wynosił 70150 tanów, a w 1919 r. wzrósł do 118028 tanów ${ }^{120}$. Cały przemysł bawełniany Chin w 1920 r. liczył 54 fabryki, z których 42\% znajdowało się w rękach kapitału obcego. W 1928 r. liczba fabryk wzrosła do 120, przy podobnym udziale własności zagranicznej ${ }^{121}$. Do głównych ośrodków przemysłu włókienniczego zaliczyć należy: Szanghaj, Qingdao, Wuhan, Tianjian i Wuhu ${ }^{122}$.

Znacznie gorzej rozwijały się inne gałęzie chińskiego przemysłu. Wydobycie węgla wzrosło z 13,6 mln ton w 1914 r. do 20,1 mln ton w 1919 r. Z tego na kapitał chiński przypadało w 1913 r. 50,7\%, a w 1919 r. - 55,2\%. Produkcja surówki stali wzrosła z 300 tys. ton w 1914 r. do 448 tys. ton w 1919 r.; wydobycie rudy żelaza wzrosło w tym czasie z 1005 tys. ton do 1861 tys. ton. Chiny nie dysponowały żadnymi zakładami produkującymi środki produkcji, które dostarczano wyłącznie przez ich import $^{123}$.

118 Miara objętości 1 tan = 103,647 1 .

119 S.L. Tychwinski (red.), op.cit., s. 651.

120 Ibidem, s. 651.

121 W. Rodziński, Chiny w ogniu. Rewolucja w latach 1925-1927, Wrocław-Warszawa-Kraków-Gdańsk-Łódź 1983, s. 8.

122 G. Jefimow, Zarys nowożytnej i wspótczesnej historii Chin..., op.cit., s. 203.

123 S.L. Tychwinski (red.), op.cit., s. 651. 
Najbardziej znamienną cechą chińskiej industrializacji był wysoki stopień i zasięg penetracji obcego kapitału. W 1914 r. wartość inwestycji zagranicznych szacuje się na ok. 1,6 mld, z czego 83,1\% ulokowano w handlu, zwłaszcza zagranicznym, 16,9\% w przemyśle i górnictwie. Obcy kapitał kontrolował chińską gospodarkę posiadając monopolistyczną pozycję w zakresie dostaw sprzętu dla wszystkich gałęzi gospodarki narodowej. Kontrolował także sektor bankowy i jego działalność kredytową ${ }^{124}$. Latem 1918 r. w Stanach Zjednoczonych powstała korporacja bankowa, której udziałowcami było początkowo 36, a w późniejszym okresie 43 banki. Jej zadaniem było utworzenie międzynarodowego konsorcjum bankowego, które przejęłoby kontrolę nad całą działalnością finansową na obszarze Chin, umożliwiając tym samym nieograniczoną eksploatację Państwa Środka ${ }^{125}$. Działalność ekonomiczna Amerykanów skierowana była przeciwko Japończykom, w związku $\mathrm{z}$ narastającym po I wojnie światowej antagonizmem między tymi mocarstwami w kwestii panowania w obszarze Azji i Pacyfiku oraz wzrostem sprzeczności między Wielką Brytanią i Japonią w obszarach ekspansji gospodarczej w Azji Wschodniej ${ }^{126}$. Japonia od 1916 r. zdominowała przestrzeń handlu zagranicznego Chin (tabela 1).

Tabela 1. Zmiany wielkości obrotu towarowego między Chinami i ważniejszymi państwami imperialistycznymi w latach 1913-1918

\begin{tabular}{|l|c|c|c|c|c|c|}
\hline \multirow{2}{*}{\multicolumn{1}{|c|}{ Państwo }} & \multicolumn{7}{|c|}{ Obroty handlowe w mln liangów } \\
\cline { 2 - 7 } & 1913 & 1914 & 1915 & 1916 & 1917 & 1918 \\
\hline Wielka Brytania & 125 & 141 & 114 & 116 & 86 & 83 \\
\hline Rosja & 101 & 99 & 115 & 137 & 92 & 32 \\
\hline
\end{tabular}

124 W. Rodziński, Chiny w ogniu..., op.cit., s. 8-9.

125 G. Jefimow, Zarys nowożytnej $i$ współczesnej historii Chin..., op.cit., s. 204.

126 J. Pajor, Chiny w polityce zagranicznej Stanów Zjednoczonych w latach 1911-1918, Łódź 2019, s. 298-299. 
cd. tabeli 1

\begin{tabular}{|l|r|r|r|r|r|r|}
\hline Niemcy & 128 & 81 & 45 & 6 & - & - \\
\hline Stany Zjednoczone & 103 & 114 & 136 & 176 & 219 & 190 \\
\hline Japonia & 126 & 131 & 135 & 181 & 224 & 275 \\
\hline
\end{tabular}

Źródło: S.L. Tychwinski (red.), Historia nowożytna Chin, tłum. M. Wolska, Warszawa 1979, s. 652.

\section{Wzrost społecznej świadomości politycznej oraz społecznego zainteresowania socjalizmem i komunizmem, kształtujące narodowy nacjonalizm, zręby społeczeństwa obywatelskiego i odrzucenie tradycji konfucjańskiej}

Wraz z końcem Chin dynastycznych ujawniły się nowe tendencje ukierunkowane na tworzenie instytucji pozarządowych w obszarach politycznym i gospodarczym oraz wielu innych pozostających poza kontrolą państwa. Impuls pojawił się wraz z pogłębianiem relacji Chin ze światem zachodnim i rozwoju aktywności chińskiej gentry w publicznej sferze życia społecznego, wspieranych przez rozwój chińskiej przedsiębiorczości, oświaty i prasy. Tworzyły się zręby społeczeństwa obywatelskiego nierozłącznie związane z ekspansją wiedzy i podziału pracy, który umożliwiał specjalistom proklamowanie autonomii w sferze swoich specjalnych kompetencji, stojąc w sprzeczności z dotychczasowym tradycyjnym porządkiem społecznym, w którym władza stanowi wszechstronny nadzór nad życiem ludzi. Przemiany te zachodziły wolno i nie zostały ukończone do czasów najnowszych. Znamiona demokracji jakie ujawniał system parlamentarny wyczerpywały się w konfrontacji stanowionego prawa $\mathrm{z}$ instytucjami państwowymi, które nie zdołały wyrwać się z wpływów feudalnego systemu stosunków społecznych. Prawo ustępowało miejsca autorytetowi urzędnika, jednostka nadal podporządkowana była in- 
teresowi grupy. Pomimo wdrażania procesów modernizacji i Nowej Nauki, całkowite odrzucenie konfucjanizmu okazało się przekraczać możliwości chińskich reformatorów niezdolnych do odrzucenia odziedziczonych chińskich wartości. Wyrazem takiego stosunku do rzeczywistości była teza ówczesnego ideologa Zhang Zhidonga: „Chińska nauka to fundament, a zachodnia wiedza służy celom praktycznym”, która uzyskała powszechną akceptację jako wyraz pierwszeństwa chińskiej nauki przed zachodnim zestawem "narzędzi praktycznych"127.

Pogłębianie „wszczepiania” europejskich wzorców spotkało istotne ograniczenie jakim była defragmentacja państwa pod wpływem plądrujących Chiny warlordów, działających przy wydatnym wsparciu zagranicy. Ich aktywności towarzyszyło wsparcie obcych armii, operujących na wodach i lądzie w związku z zagrożeniem pochodzącym ze strony wspieranych awanturników. W tych warunkach kształtował się chiński nacjonalizm ukierunkowany przeciwko siłom zewnętrznym oraz wewnętrznym oprawcom, poszukujący koncepcji społecznych między autorytarnym kolektywizmem a liberalnym indywidualizmem $^{128}$.

Wraz z rozwojem gospodarczym rosła liczba chińskich robotników. W $1913 \mathrm{r}$. w chińskim przemyśle zatrudnionych było ok. 650 tys., w 1918 r. 1,75 mln, a w 1919 r. 2,35 mln. Ponad $10 \mathrm{mln}$ robotników najemnych zatrudnienie znalazło w handlu, także w rolnictwie pracowało wiele milionów robotników rolnych ${ }^{129}$. W 1920 r. 870 tys. robotników zatrudnionych było w górnictwie, 1100 tys. w przemyśle, 200 tys. w transporcie, 150 tys. w portach. Ogólna ich liczba stanowiła zaledwie

127 Por. J.K. Fairbank, op.cit., s. 237-240.

128 Szerzej: J. Haapanen, Adaptation to World Trends. A Rereading of the May Fourth Movement Radicalization, Juvaskyla 2013, s. 236.

129 S.L. Tychwinski (red.), op.cit., s. 654. 
$1 \%$ całego społeczeństwa ${ }^{130}$. Ogromna rezerwa siły roboczej przyczyniała się do bardzo złej sytuacji materialnej tej grupy społecznej, wynikająca zwłaszcza z braku właściwego ustawodawstwa i ubezpieczeń społecznych oraz braku instytucji odpowiedzialnych za ochronę ich interesów. Robotnicy, którymi kierowały głównie różne tajne stowarzyszenia, bractwa, ziomkostwa i zrzeszenia cechowe, pozostawali pod wpływami przedsiębiorczych pośredników, kupców, a nawet przywódców band. Jedynie fakt znacznego stopnia koncentracji robotników $\mathrm{w}$ uprzemysłowionych regionach pomagał $\mathrm{w}$ uwalnianiu zjawisk sprzeciwu, na początku żywiołowego i stopniowo coraz bardziej zorganizowanego.

Pomimo że Zachód ostro krytykowany był przez konserwatywną część chińskiego społeczeństwa, to jednak zachodni model stosunków społecznych oddziaływał na poglądy chińskiej inteligencji. Chiny przeprowadziły zmiany systemu kształcenia, wprowadzając trójstopniowy system kształcenia. Kontakty z zagranicą umożliwiły podjęcie studiów na uczelniach zachodnich, zwłaszcza w Japonii. Na początku XX w. liczba studentów chińskich w Japonii szybko wzrastała: w 1904 r. było ich 130 , a w 1905 r. -8 tys. ${ }^{131}$, a w 1907 r. było ich już około 15 tys. ${ }^{132} \mathrm{~W}$ tym czasie w Europie studiowało ok. 400 Chińczyków, a w USA ok. $800^{133}$. Rozwój szkolnictwa w Chinach przyczyniał się do zmniejszania poziomu analfabetyzmu; w 1910 r. r. na terenie Chin działało ok. 57 tys. szkół zatrudniających ok. 89 tys. nauczycieli. Liczbę uczniów szacowano w tym czasie na ok. 1,6 $\mathrm{mln}^{134}$. Dziesiątki tysięcy młodych ludzi studiowało filozofię zachodnią od liberalizmu począwszy,

\footnotetext{
130 W. Rodziński, Chiny w ogniu..., op.cit., s. 9.

131 S.L. Tychwinski (red.), op.cit., s. 419.

132 W. Rodziński, Historia Chin..., op.cit., s. 538.

133 Ibidem.

134 Ibidem.
} 
a skończywszy na Marksie. Rynek księgarski wypełniały przekłady literatury zachodniej. Rezygnując z przyjęcia kontrybucji „bokserskiej” Stany Zjednoczone przekazały swoją część (12 mln USD, tj. 50\% odszkodowania ustalonego w protokole bokserskim) na wsparcie chińskiej edukacji, finansując zarów no uczelnie tworzone przez misję amerykańskiego Kościoła episkopalnego w Chinach, jak również fundując stypendia dla chińskich studentów w USA. Często językiem wykładowym był angielski ${ }^{135}$.

Wzorem Zachodu, w Chinach rozpowszechniało się dziennikarstwo i wydawnictwo prasy, rosła także liczba czytelników, szacowanych w latach 30. XX w. na 20-30 mln. W 1912 r. wydawano w Chinach ok. 500 dzienników, a w 1928 ok. 600. Tylko w Szanghaju i Pekinie ukazywało się 40-50 gazet o nakładach dochodzących do 150 tys. egzemplarzy ${ }^{136}$. Na znaczną skalę publikowano czasopisma i podręczniki oraz masową beletrystykę. Dziennikarstwo polityczne miało charakter głównie polemiczny, koncentrowało się na krytyce i obronie, rzadziej na informowaniu o faktach. Stopniowo prasa stawała się ważnym narzędziem agitacji i walki politycznej ${ }^{137}$.

Geograficznym i duchowym centrum Nowej Kultury był założony w 1898 r. Uniwersytet Pekiński, zwany na początku Uniwersytetem Cesarskim - ośrodkiem kształcącym i dokształcającym pracowników cesarskiej administracji rządowej. Po rewolucji w $1911 \mathrm{r}$. rektorem uniwersytetu został reformator Yan Fu, pierwszy tłumacz Milla i Spencera na język chiński. Pomimo że piastował stanowisko zaledwie kilka miesięcy, podniósł on znacznie poziom kształcenia zatrudniając wybitnych wykładowców. Wśród tych, którzy dołączyli do kadry uniwer-

135 Por. J.K. Fairbank, op.cit., s. 244-245.

136 R. Mitter, Gorzka rewolucja. Zmagania Chin z nowoczesnym światem, tłum. T. Białogórska, Warszawa 2008, s. 84-85.

137 Por. J.K. Fairbank, op.cit., s. 242-243. 
sytetu byli m.in. Chen Duxiu i Li Dazhao, późniejsi założyciele Komunistycznej Partii Chin, oraz Hu Shi - jeden z najwybitniejszych literatów współczesnych Chin. W 1916 r. stanowisko rektora objął Cai Yuanpei. Był znakomitym uczonym, orędownikiem nowoczesnej edukacji, wyedukowanym na uczelni w Niemczech. Propagował „wolność akademicką", której efektem były publikacje krytykujące moralność konfucjańską i konfucjański system wartości na rzecz swobody jednostki i rozwoju indywidualnego oraz budowania nowego światopoglądu ${ }^{138}$.

Drugim wielkim ośrodkiem Nowej Kultury był Szanghaj otwarte miasto kolonialne liczące ok. 1,2 mln mieszkańców, aspirujące do rangi metropolii na miarę Tokio, Paryża czy Nowego Jorku, w którym koncentrował się wielki biznes i najważniejsze centrale bankowe, m.in. Hongkong and Shanghai Bank. Architektura ówczesnego miasta nawiązywała stylem do budownictwa europejskiego i amerykańskiego z dużym udziałem kilkunastopiętrowych wysokościowców. W mieście panowała stosunkowo duża swoboda polityczna i tolerancja dla zachodniego stylu życia. Nie wyeliminowano tu jednak postaw ksenofobicznych i rasistowskich. Chińczycy często byli narażeni na rasistowskie traktowanie przez Brytyjczyków, Francuzów, Amerykanów i Japończyków. Niektóre miejsca publiczne były dla nich niedostępne. $Z$ pozoru kosmopolityczne miasto było miejscem rozwoju chińskiego nacjonalizmu ${ }^{139}$.

Pomimo że Uniwersytet Pekiński cieszył się największym prestiżem spośród chińskich uczelni, to Szanghaj zapewniał możliwość kształcenia na wszystkich poziomach i dla wszystkich warstw. Uniwersytet Świętego Jana, założony tam w 1879 r., kształcił dzieci lokalnej elity i stał się w latach 20. XX w. najwybitniejsza uczelnią chrześcijańską. Natomiast Uniwersytet

\footnotetext{
138 R. Mitter, op.cit., s. 59.

139 Ibidem, s. 63-64.
} 
Szanghajski, założony w 1922 r., miał opinię bardziej radykalnego, wśród wykładowców byli komunistyczni luminarze, tacy jak Qu Qiubai (przyszły przywódca KPCh) i Deng Zongxia. Istotnym elementem nauki był język angielski, w którym publikowano większość podręczników do nauki nowych zachodnich przedmiotów ${ }^{140}$.

Wraz z Ruchem Nowej Kultury w Chinach przyjmować się zaczął nowy sposób myślenia o społecznej roli jednostki, czemu sprzyjał wzrost poczytności literatury popularnej, zwłaszcza w upowszechnianiem potocznego języka, zastępującego skostniały język konfucjański ${ }^{141}$. Odrzucono konfucjańskie dogmaty skromności i kolektywnego dobra, na rzecz zachodnich wzorców samorealizacji i rozwijania własnej indywidualności, których beneficjentem stały się także chińskie kobiety, które uzyskały powszechny dostęp do nauki i edukacji, podejmując zastrzeżoną wyłącznie dla mężczyzn działalność w zawodach robotniczych oraz w wolnych grupach zawodowych lekarzy, nauczycieli, prawników, literatów itp. Pod wpływem aktywności tworzącej się kultury konsumpcyjnej w wielkich ośrodkach miejskich rozwijał się ruch na rzecz praw kobiet, czego wyrazem było wywalczenie przez chińskie kobiety (jedynie nominalnie) w $1927 \mathrm{r}$. konstytucyjnych praw wyborczych i obywatelskich ${ }^{142}$. Jednak kwestia feminizmu napotkała silny opór konserwatystów, to jednak w okresie Ruchu na rzecz Nowej Kultury była stawiana najbardziej otwarcie, znajdując najszersze poparcie społeczne ${ }^{143}$.

140 Ibidem, s. 65.

141 Szerzej: Ch.W. Hayford, Literacy Movemoment in Modern China, (1987), https://www.researchgate.net/publication/300450509_Literacy_ Movements_in_Modern_China [dostęp: 6.08.2019].

142 M. Koetse, Gendered Nationalism and May Fourth: China's „New Woman" (8.12.2012), https://www.manyakoetse.com/gendered-nationalismand-may-fourth-chinas-new-woman/ [dostęp: 23.08.2019].

143 Szerzej: M. Mencel, Kobieta w Chinach: kulturowa przeszłość $i$ te- 
Wpływy kultury zachodniej na Ruch Nowej Kultury w Chinach, poza obszarem politycznym i ogólnospołecznym ujawniły się także w wymiarze sztuki i literatury. Chińska sztuka skorzystała z wpływów obrazoburczych nastrojów antykonfucjańskich, przejmując wzorce zachodnie. Wielu artystów wyjeżdżało do Europy, głównie do Francji i Wielkiej Brytanii, inni udawali się na studia do Japonii. Niektórzy z nich uzyskiwali rządowe wsparcie stypendialne przez utworzoną Akademię Narodową w Pekinie, która przeznaczała część środków na studia sztuk pięknych w Europie ${ }^{144}$. Szybko rosła liczba w Chinach liczba szkół pięknych, wnoszących do chińskiej sztuki pierwiastek zachodniej kultury. Skupieni wokół szkół w Sznaghaju, Nankinu, Hangzhou, Pekinu i Kantonu zwolennicy nowej sztuki skupili swe wysiłki na tworzeniu towarzystw sztuki i organizowaniu wystaw, otwierając tym samym nowe możliwości wymiany idei. Czasopisma powstające w wyniku Ruchu 4 Maja stały się najlepszym środkiem prezentowania nowych stylów i teorii szerszemu gronu odbiorców, stając się wyzwaniem dla autorytetów chińskiej sztuki tradycyjnej, a wyrazem aktywności chińskich artystów było zorganizowanie w 1924 r. pierwszej w Europie wystawy chińskiej sztuki nowoczesnej, często łączącej techniki wyuczone na europejskich studiach z tradycyjnymi chińskimi metodami wyrazu artystycznego ${ }^{145}$.

Przedstawiony obraz fragmentu Chin "nowoczesnych" nie może zdominować faktycznego stanu chińskiej rzeczywistości: powszechna nędza, życie na pograniczu ubóstwa i głodu, codziennej walki o byt zdecydowanej większości mieszkańców tych dwóch (i in.) ogromnych metropolii, wypchniętych na

raźniejszość, [w:] Kobiety w życiu kulturowym Polski i świata, red. A. Chodubski, A. Frączek, B. Słobodzian, Gdańsk 2012, s. 208-227.

144 A.I. Król, Chiny w latach 1898-1937 - między artystyczną tradycją a sztukq Zachodu, Warszawa-Toruń 2016, s. 71.

145 Ibidem, s. 68-75. 
peryferia miast, dostarczających taniej siły roboczej zarówno imperialistycznym przedsiębiorcom, jak również rodzimej burżuazji, źródeł wyzysku dla centralnych i lokalnych przywódców. Równie dramatycznie przedstawiała się sytuacja mieszkańców chińskiej wsi, której populacja stanowiła ponad $80 \%$ ogólnej liczby ludności Chin liczącej w latach 20. XX w. 430-480 mln ludności, pozostającej w głęboko osadzonych feudalnych stosunkach społecznych. Pomimo niepodważalnej pracowitości chińskich chłopów, poziom chińskiego rolnictwa był zacofany pod względem technicznym, zwłaszcza w porównaniu z wielkotowarowymi gospodarkami rolnymi państw zachodnich. $\mathrm{Na}$ większości obszarów rolniczych dominowały zasady gospodarki naturalnej lub półnaturalnej wyrażające się w autarkicznej samowystarczalności, bez istotnych powiązań z gospodarką rynkową, ograniczającą się przede wszystkim do prowincji nadbrzeżnych i terenów podmiejskich. Ówczesne rolnictwo chińskie cechowało nadmierne wykorzystanie nieograniczonej ludzkiej siły roboczej, intensywne metody kultywacji, całkowity prymat produkcji roślinnej i minimalne znaczenie hodowli zwierząt. Utrzymanie systemów irygacji spoczywało na lokalnej i centralnej władzy, niezainteresowanej kierowaniem nakładów inwestycyjnych na ich modernizację, co w wielu regionach prowadziło do zmniejszania uzyskiwanych plonów wywoływanych zjawiskami suszy lub powodzi. Strażnikiem niezmienności systemowej była ukształtowana przez wieki specyficzna dla Chin biurokracja i jej przedstawiciele, którzy z jednej strony doprowadzili do olbrzymiego postępu cywilizacyjnego Chin dynastycznych, gwarantowali także stabilizację systemowo-kulturową w cesarstwie, z drugiej zaś przyczynili się do społeczno-gospodarczej stagnacji, która doprowadziła Chiny do zacofania i opóźnienia cywilizacyjnego w stosunku do Zachodu i Japonii, w których przeobrażenia kreowane były przez rewolucję przemysłową, kapitalizm, a następnie demokratyczne systemy 
państwowe. Od XIX w. poważnym ciężarem dla Chin stał się problem przeludnienia wsi i brak proporcji pomiędzy ogólnym wzrostem liczby ludności do wzrostu produkcji, w konsekwencji którego postępował proces ubożenia mieszkańców, zwłaszcza na obszarach wiejskich. Malał stosunek powierzchni ziemi rolnej do liczby mieszkańców ${ }^{146}$. W okresie od 1901 do 1928 r. liczba ludności wzrosła o $50 \mathrm{mln}$, akumulując się głównie na wiejskich terenach kraju, gdzie nie docierały tendencje i trendy niesione przez Ruch Nowej Kultury. Na radykalny wzrost liczby ludności wsi wpływał czynnik tradycyjny, wywodzący się z kultury konfucjańskiej, zgodnie z którym zawód rolnika otaczano szczególnym szacunkiem, a przywiązanie do licznego potomstwa wynikało z patriarchalnych obyczajów społecznych. Także administracja centralna i lokalna koncentrowała na obszarach wiejskich wysiłki wspierające tradycyjny system wartości. Wieś była głównym płatnikiem podatków, dostarczała siły roboczej i rekruta dla armii rządowej i lokalnych warlordów ${ }^{147}$. Przytłaczająca większość chłopów nie posiadała żadnych zasobów finansowych, zaciągała zatem często pożyczki, których na lichwiarskich warunkach udzielali wielcy obszarnicy lub lokalni przedstawiciele administracji. Zwrot pożyczki wraz z obowiązkowymi daninami często był ciężarem nie do udźwignięcia przez chińskich chłopów, w konsekwencji tracili swoje ziemie i popadali w niewyobrażalną nędzę. Rewolucja kultural-

146 Ocenia się, że 50\% gruntów rolnych należało do obszarników, 33\% do bogatych i średnich chłopów, a tylko 17\% pozostawało w rękach najbiedniejszych chłopów. Chińską wieś charakteryzował także wysoko poziom rozwarstwienia: 70\% stanowili biedni chłopi i robotnicy rolni, 20\% chłopi średniozamożni, zaś 10\% obszarnicy i bogaci chłopi. Zatem 10\% ludności chińskiej wsi osiągało dochody z $88 \%$ areału. W. Rodziński, Chiny w ogniu..., op.cit., s. 4-5.

147 Szerzej: M.T. Mencel, Wiejski charakter chińskiego społeczeństwa, [w:] idem, Chińska Republika Ludowa jako wspótczesny podmiot środowiska międzynarodowego, t. III: Rozważania o rzeczywistości, Torun 2016, s. 894-960. 
na, która opanowała zurbanizowane obszary chińskich miast i nadmorskich prowincji, w żaden sposób nie oddziaływała na chińską wieś, przyczyniając się do wytworzenia swoistego dualizmu społecznego, dzielącego społeczeństwo na rewolucyjne, reformatorskie, pronowoczesne (ok. 10-15\% ludności) i prodemokratyczne oraz tradycyjne i konserwacyjne. $Z$ perspektywy czasu uznać należy, że szanse na zwycięstwo Ruchu 4 Maja równe były zeru.

W tych warunkach atrakcyjną wydała się wielu Chińczykom oferta z jaką wyszli przedstawiciele Związku Sowieckiego po zwycięstwie rewolucji październikowej. W odezwie z 3 grudnia 1917 r. rząd radziecki oświadczył, że wyrzeka się wszystkich nierówno prawnych układów rządu carskiego z narodami wschodnimi i unieważnia tajne umowy z innymi mocarstwami, ograniczające suwerenne prawa narodów wschodnich. Do Chin zaczęły docierać wiadomości o zasadach ustroju politycznym radzieckiego państwa, marksistowsko-leninowskiej ideologii i ich wpływu na „oswobodzenie” narodu Rosji z władzy samodzierżawia oraz kolonialnego ucisku ${ }^{148}$. Chińska prasa publikowała doniesienia o wydarzeniach w Rosji, zwłaszcza w kontekście propozycji Rady Delegatów Robotniczych i Żołnierskich dotyczącego „zawarcia demokratycznego pokoju”, „zniesienia obszarniczej własności ziemi i przekazanie jej chłopom". Wiadomości, że w Rosji władzę zdobyli robotnicy i chłopi, szerokim echem przeszły przez Chiny, a wymiar jakościowy podniosła deklaracja radzieckich władz z 10 lutego 1918 r. o anulowaniu Chinom długu z tytułu udzielonych pożyczek oraz anulowaniu chińsko-rosyjskiego traktatu z $1896 \mathrm{r}$. i protokołu bokserskiego z 1901 r. Zgodnie z radziecką deklaracją z 25 lipca 1919 r. stosunki chińsko-radzieckie winny opierać się na zasadzie nieingerencji w wewnętrzne sprawy Chin. W 1920 r. Kolej Da-

148 Por. G. Jefimow, Zarys nowożytnej $i$ wspótczesnej historii Chin..., op.cit., s. 206-207. 
lekowschodnia zarządzana i nadzorowana przez Rosjan został przejęta przez mandżurskiego warlorda Zhang Zuolina ${ }^{149}$. Od tego czasu radzieccy komuniści wykazywali znaczne zaangażowanie w nawiązaniu stosunków z Chinami, wysyłając do Pekinu oficjalne delegacje, których zadaniem było głównie budowanie pozytywnych relacji i zaufania. W związku z brakiem zrozumienia ze strony państw zachodnich, z sowieckiej propozycji skorzystał Sun Yat-sen, który w liście do Gieorgija Cziczerina (24.11.1872-7.07.1936) miał pisać: „Jestem bardzo zainteresowany waszą sprawą, zwłaszcza organizacją waszych Rad, waszej armii i oświaty [...]. Podobnie jak Moskwa, chciałbym wszczepić zasady Republiki Chińskiej głęboko w umysły młodego pokolenia - ludzi pracy dnia jutrzejszego"150. Po kilkuletnich kontaktach z przedstawicielami Kominternu, obie strony ustaliły zasady wzajemnej współpracy: 7 stycznia $1923 \mathrm{r}$. Sun Yat-sen zaakceptował zasady polityki Moskwy wobec Chin, a 31 maja 1924 r. zawarto chińsko-radziecki traktat współpracy ${ }^{151}$. Intensyfikacji uległy relacje Guomindangu z Kominternem, którego doradcy uczestniczyli w reorganizacji Narodowej Partii Chin wg radzieckich wzorców.

W literaturze przedmiotu podkreśla się znaczenie Ruchu 4 Maja na rzecz kształtowania zrębów Komunistycznej Partii Chin $^{152}$. Trudno jednak dostrzec bezpośrednie związki między ogólnospołecznym ruchem sprzeciwu wobec antyspołecznych feudalnych stosunków wewnętrznych i ucisku warlordowskich ciemiężycieli oraz upokarzającej dominacji imperializmu obcych

149 W. Rodziński, Chiny w ogniu..., op.cit., s. 37-38.

150 W.I. Głunin, Przypływ ruchu narodowowyzwoleńczego w Chinach (1917-1924), [w:] Najnowsza historia Chin (1917-1976), red. G.W. Astafiew, W.N. Nikiforow, M.I. Sładkowskij, Warszawa 1976, s. 108.

151 Ibidem, s. 39-42.

152 Por. K. Gawlikowski, Nowa batalia o Konfucjusza, Warszawa 1976, s. 50-51. 
mocarstw, z kształtowaniem postaw komunistycznych. Niemniej główni twórcy KPCh byli również w ariergardzie Ruchu 4 Maja i tym związkom trudno zaprzeczać, chociaż właściwym jest podkreślenie związków pierwszych teorii chińskich komunistów z europejskim i rosyjskim anarchizmem, niemających wiele wspólnego z ortodoksyjnym marksizmem. Protoplaści chińskiego komunizmu sięgali raczej do teorii Proudhona, Bakunina i Kropotkina, dostrzegając w nich wzorce kontestacji wszelkich autorytetów, zwłaszcza wywodzących się ze środowiska władzy i aparatu przymusu, sięgających nawet podstaw społecznych jakim jest rodzina, na rzecz egalitarnej utopijnej wspólnoty ${ }^{153}$.

Nie ulega wątpliwości, że na fali Ruchu na rzecz Nowej Kultury wzrosło w Chinach zainteresowanie teorią i praktyką socjalistyczną socjalizmu i komunizmu, zwłaszcza w wyniku rozczarowań relacjami z Zachodem ${ }^{154}$, zaś do protoplastów chińskiego komunizmu zaliczyć należy m.in. Li Dazhao (1888-1927), Zhen Duxiu (1879-1942), jednych z głównych działaczy Ruchu 4 Maja.

Li Dazhao był profesorem Uniwersytety Pekińskiego, głównego wówczas ośrodka ruchu intelektualnego w Chinach. Już w 1918 r. opublikował on w postępowym czasopiśmie „Nowa Młodzież" (Xin Qingnian) artykuł gloryfikujący idee rewolucji październikowej w Rosji ${ }^{155}$. Podejmując fanatyczną walkę ideologiczną z konfucjanizmem głosił hasło „Rozwalić kram Konfucjusza i jego dziedziców", zachęcając do odrzucenia wszystkiego co stare i reakcyjne, zwłaszcza zasady posłuszeństwa synowskiego, uznawanego za fundament Chin feudalnych ${ }^{156}$. Już w $1918 \mathrm{r}$. Li Dazhao powołał Marksistowskie Towarzystwo Naukowe ${ }^{157}$,

153 Por. J.K. Fairbank, op.cit., s. 255-256.

154 J. Bayer, W.J. Dziak, Historia polityczna Chin 1839-2014. Konspekt analityczny..., op.cit., s. 127.

155 W. Rodziński, Chiny w ogniu..., op.cit., s. 51.

156 Por. K. Gawlikowski, op.cit., s. 51.

157 M. Kukowski, Proces przyjęcia i odrzucenia japońskiego wzoru przez 
które stawiało sobie za cel pogłębianie filozofii marksistowskiej i utworzyło w 1920 r. liczące dziewięć osób kółko komunistyczne w Pekinie ${ }^{158}$. W czasie wydarzeń w 1919 r. Li opublikował własne tłumaczenie pierwszej części Manifestu komunistyczne$g{ }^{159}$. Li Dazhao został aresztowany z rozkazu Zhang Zuolina i 28 kwietnia 1927 r. stracony w Pekinie wraz z dziewiętnastoma innymi komunistami ${ }^{160}$.

W 1919 r. poparcie dla komunistycznej ideologii ogłosił na łamach „Nowej Młodzieży” Zhen Duxiu ${ }^{161}$, dziekan Wydziału Humanistycznego Uniwersytetu Pekińskiego, założyciel pierwszego kółka komunistycznego we wrześniu $1920 \mathrm{r}$. w Szanghaju, liczącego siedem osób ${ }^{162}$. Zhen konstruował poglądy podobne do Li Dazhao, jednak były one zdecydowanie bardziej radykalne. W słynnym apelu do młodych wzywał przedstawiciel młodego pokolenia do niezależności, pozwalającej na kreowanie w większym stopniu własnej osobowości. Krytyczne słowa padły wówczas pod adresem ludzi starszych, którzy w warunkach chińskich mieli przemożny wpływ na kształtowanie postaw. Zdaniem Chena ta formuła wyczerpała się, dlatego należało stworzyć pole do działania dla młodych umysłów. Chen zachęcał, by czerpać z dorobku innych kultur poprzez otwarcie się na nowe rozwiązania. Odrzucał stare mity i wyobrażenia, przywiązując dużą wagę do reformy pi-

Chiny. Od końca XIX wieku do 1937 roku, https://mysl.lazarski.pl/fileadmin/ user_upload/dokumenty/czasopisma/mysl-ekonomiczna-polityczna/2014/ MEiP_1_7_2014_Kukowski.pdf [dostęp: 5.08.2019].

158 W.I. Głunin, op.cit., s. 89.

159 Ł. Gacek, Rola konfucjanizmu w ksztattowaniu ideologii państwowej w Chinach $w$ XX wieku, „Krakowskie Studia Międzynarodowe” 2015, nr 3, s. 29.

160 Li Dazhao, https://pl.wikipedia.org/wiki/Li_Dazhao [dostęp: 5.08.2019].

161 W. Rodziński, Chiny w ogniu..., s. 27.

162 W.I. Głunin, op.cit., s. 89. 
sma. Dzięki doświadczeniom zdobytym podczas studiów w Japonii i Francji, Chen zainteresował się doktryną socjalistyczną. Nawoływał później do przeprowadzenia zmian ustrojowych zgodnie z teoriami socjalistycznymi, odrzucając zdecydowanie spuściznę konfucjańską. Na podkreślenie zasługuje fakt, iż Chen Duxiu został wykształcony na bazie kanonu klasycznych ksiąg konfucjanizmu, co nie przeszkodziło mu później wyrażać diametralnie odmiennych poglądów ${ }^{163}$. Jego hasłem przewodnim w czasie Ruchu 4 Maja było: „Obalić stare idole! Burzyć wszystko!"164, które zdecydowanie wyrażało jego anarchistyczne poglądy. Twierdził on, że konfucjanizm jest produktem epoki feudalnej i nie odpowiada potrzebom czasów nowożytnych, widział w nim jeden z głównych hamulców rozwoju Chin, przyczynę zacofania kraju. Zarzucał konfucjanizmowi uprawianie pustych rytuałów, propagowanie zgody i posłuszeństwa uniemożliwiających walkę i konkurencję, narzucanie postawy pasywnej całemu narodowi. Jego zdaniem czasy nowożytne dążą do rozwoju jednostki, umocnienia jej praw, bez czego demokracja, rozwój gospodarczy i polityczny ani budowa silnego państwa nie są możliwe, zaś konfucjanizm przyjmuje za podstawę rodzinę i klan, jest ideologią niszczącą wszelki indywidualizm. Wskazywał, że przekształcenie konfucjanizmu w religię państwową, wybór tej drogi budowy nowoczesnych Chin jest sprzeczny z racjonalistycznym duchem konfucjanizmu ${ }^{165}$. Zarówno Zhen Duxiu, jak też Li Dazhao krytykowali konfucjański stosunek do kobiet, żądając zdecydowanej zmiany pozycji kobiet w społeczeństwie ${ }^{166}$.

\footnotetext{
163 Ł. Gacek, op.cit., s. 29.

164 Por. K. Gawlikowski, op.cit., s. 51.

165 Ibidem.

166 Por. R. Sławiński, „Nowy” konfucjanizm w krajach Azji Wschodniej, „Krakowskie Studia Międzynarodowe” 2010, nr 1, s. 142-143.
} 
Radykalny stosunek do konfucjanizmu wykazał Lu Xun (1881-1936), wskazywany często jako czołowa postać Ruchu 4 Maja i największy pisarz współczesnych Chin. W 1918 r. opublikował na łamach „Nowej Młodzieży” esej pt. Moje poglady na czystość, w którym potępiał tradycyjne podejście do miejsca i roli kobiet w społeczeństwie ${ }^{167}$. W publikacji Dziennik szalonego wskazywał konfucjanizm jako doktrynę kanibalizmu. Anonimowy bohater opowiadania konstatuje sytuację w Chinach: „Dopiero dzisiaj dotarło do mnie, że, że ja też przez wiele lat żyłem tu, w tym miejscu, gdzie od czterech tysiącleci stale zjada się ludzi”168. „Po czterech tysiącach lat uprawiania kanibalizmu poczułem się tym niespodziewanie zawstydzony. Jeśli są dzieci, które nie praktykowały jeszcze kanibalizmu, uratujcie je"169. Pomimo że praktyki kanibalizmu były w chińskiej rzeczywistości zjawiskiem marginalnym, to jednak przypominanie ich budziło żywe emocje, wzmacniając antykonfucjańskie nastroje. Twierdzono, że moralność konfucjańska zabija człowieczeństwo w człowieku, jest podstawą nieludzkich stosunków społecznych, ucisku przyjmowanego nawet bez buntu, „pożerania ludzi” przez despotów i bogaczy. Lu Xun dowodził, że to właśnie nieludzka tradycja konfucjańska przygniatająca ludzi grozi Chińczykom unicestwieniem. Występował on za przyjmowaniem tylko tego co nowe i postępowe z Zachodu, z Rosji, z dorobku nowych Chin, a za odrzuceniem wszystkiego co stare i konserwatywne ${ }^{170}$.

Pomimo swej nacjonalistycznej wymowy ruch Nowej Kultury przyswajał zachodni system wartości dążąc do zapewnienia Chinom godnego miejsca w międzynarodowym środowisku. Sposób życia ludzi zaczęto postrzegać wraz z kulturowym

\footnotetext{
167 R. Mitter, op.cit., s. 113.

168 Ibidem, s. 114.

169 K. Gawlikowski, op.cit., s. 52.

170 Ibidem, s. 53.
} 
i politycznym kontekstem. Po raz pierwszy w długiej historii Chin zasadnicze miejsce w publicznej debacie zajął status kobiet, charakter nowoczesnego małżeństwa i modelu stosunków rodzinnych. Antyimperialistyczną i antyfeudalną postawę społeczeństwa wyrażała koncepcja radykalnego w swoich poglądach Chen Duxiu, który wskazywał, że Chinom potrzebni byli „Pan Nauka” i „Pan Demokracja”. Rolą pierwszego miało być zastąpienie konfucjańskich klasyków pozytywnym, racjonalnym sposobem rozumowania, zaś drugiego - promocja nowego systemu moralnego oraz wolności politycznej. Obaj „panowie” gwarantować mieli szanse na przetrwanie wpisanej w darwinizm społeczny rywalizacji z Zachodem - zwłaszcza Japonią oraz warlordowskiej pazerności $i^{171}$.

Bezpośredni wpływ na wybuch Rewolucji 4 Maja miały wydarzenia podczas obrad konferencji pokojowej w Paryżu. Poprzedził je sprzeciw chińskiego społeczeństwa wobec decyzji rządu Duana Qirui o udziale chińskich sił zbrojnych w interwencji czternastu państw przeciwko Rosji sowieckiej na Dalekim Wschodzie. Porozumienia z 16 i 19 maja 1918 r. o podporządkowaniu skierowanych oddziałów chińskich dowództwu japońskiemu doprowadziły do organizacji w Tokio przez chińskich studentów strajku protestacyjnego. Podczas wiecu podjęli oni decyzję o masowym opuszczeniu Japonii i powrocie do Chin: do końca 1918 r. Japonię opuściło ok. 3 tys. chińskich studentów, którzy po powrocie do kraju rozpoczęli masową agitację antyimperialistyczną i antymilitarystyczną w Szanghaju, Pekinie i innych miastach. 21 maja 1918 r. studenci wielu uczelni w Pekinie rozpoczęli strajk protestacyjny przeciwko japońsko-chińskim porozumieniom wojskowym i przeprowadzi-

171 J. Fenby, op.cit., s. 227. 
li manifestacje przed siedzibą rządu. Manifestanci protestowali przeciwko agresywnym układom wojskowym, przeciw udziałowi Chin w interwencji antyradzieckiej, przeciw prowadzonej przez rząd Duana polityce zdrady narodowej i domagali się nawiązania przyjaznych stosunków z Rosją sowiecką ${ }^{172}$. Wystąpienia i żądania studentów spotkały się z poparciem różnych warstw chińskiego społeczeństwa, a nawet samego Sun Yat-sena. Opowiedział się on za uznaniem Rosji sowieckiej, a rewolucja październikowa wywarła duży wpływ na poglądy Suna. W telegramie gratulacyjnym wysłanym do Lenina wskazywał, że „Rewolucyjna Partia Chin wyraża głęboki zachwyt dla trudnej walki, jaką wiedzie rewolucyjna partia waszego kraju, i sądzi, że rewolucyjne partie Chin i Rosji zespolą się dla wspólnej walki"173.

Równolegle do zainteresowania wydarzeniami zachodzącymi w Rosji sowieckiej, ogromne nadzieje na wzmocnienie pozycji Chin wobec japońskiego imperializmu wielu światłych obywateli wiązało z porządkiem międzynarodowym zaprowadzanym podczas konferencji pokojowej w Paryżu po zakończeniu I wojny światowej, a zwłaszcza ogłoszonymi przez prezydenta Woodrow Wilsona zasadami zawartymi w jego "14 punktach” oraz deklaracjami składanymi przed konferencją o konieczności przywrócenia suwerenności Chin nad zaanektowanymi terytoriami. Jednak postawa uległości Wilsona wobec japońskich nacisków wspieranych przez Brytyjczyków i Francuzów podczas konferencji rozczarowała chińskich patriotów. Żądania przedstawione przez chińską delegację zostały w całości odrzucone. Podczas konferencji oświadczono, że kwestia japońskich „21 żądań” nie mieści się w obszarze prac konferencji, a chińskie postulaty zdecydowano rozpatrywać

\footnotetext{
172 S.L. Tychwinski (red.), op.cit., s. 665-666.

173 Ibidem, s. 666.
} 
$\mathrm{w}$ trybie przewidzianym przez powołaną instytucję - Ligę Narodów. W sprawie Shandongu traktat pokojowy stanowił, iż prawa i przywileje uzyskane przez Niemcy uzyskane przez Niemcy na podstawie chińsko-niemieckiej umowy z 6 marca 1898 r., jak również na podstawie wszystkich innych umów Szantung oraz terytorium Jiaozhou, koleje, kopalnie, kabel morski itp. w całości przejmuje Japonia. Japonia przejmowała prawa Niemiec do kolei żelaznej Jiaozhou - Jinan i do wszystkich jej bocznic oraz całe mienie tej kolei, jak również wszystkie kopalnie i urządzenia, a także związane z tym prawa i przywileje. Kabel morski ciągnący się z Tsingtao do wyspy Tajwan oraz całe przynależne doń mienie również przechodziły bez odszkodowania we władanie Japonii ${ }^{174}$.

Wiadomość o decyzjach podjętych podczas konferencji pokojowej w Paryżu dotarła w pierwszej kolejności do młodych Chińczyków studiujących na francuskich uczelniach, którzy zainicjowali akcję protestacyjną przed hotelem, w którym zakwaterowana została chińska delegacja rządowa, uniemożliwiając podpisanie przez Chińczyków traktatu pokojowego ${ }^{175}$. Wiadomości z Paryża błyskawicznie dotarły do Pekinu, eskalując oburzenie i sprzeciw studentów, którzy 4 maja 1919 r. zorganizowali na pekińskim placu Tiananmen masowy wiec, z którego ok. 3 tys. osób, wyposażonych w transparenty z hasłami w stylu: Precz ze zdrajcami" ${ }^{176}$, skierowało się do dzielnicy ambasad. Ich celem stał się dom Cao Rulina, ministra komunikacji uznawanego za jednego ze „zdrajców narodu”, który przehandlował Japonii niezależność ekonomiczną i polityczną Chin. Dom został zdemolowany, minister zbiegł do hotelu dla cudzoziemców, a ofiarą tłumu padł japoński gość ministra, którego obrzucono

\footnotetext{
174 A. Malicka (red.), op.cit., s. 38.

175 J. Fenby, op.cit., s. 224.

176 B. Góralczyk, Pekińska wiosna 1989. Poczq̨tki ruchu demokratycznego w Chinach, Warszawa 1999, s. 15-16.
} 
jajami, a całe odium złości tłumu padło na byłego chińskiego posła w Japonii - Zhang Zangxianga, który gościł w domu Cao Rulina. Zhang został dotkliwie pobity przy użyciu metalowych elementów zdemontowanych z żelaznego łóżka. Następnie dom podpalono, po czym do akcji wkroczyła policja aresztując kilkudziesięciu sprawców ${ }^{177}$. Kolejne aresztowania w Pekinie miały miejsce $w$ dniach 2 i 3 czerwca. Protesty i rebelie wybuchły także w innych miastach. Przyłączyli się studenci miast Tianjinu, Szanghaju, Nankinu, Wuhanu, Fuzhou, prowincji Guangdong, Kuangsi, Shanxi, Shaanxi, Zhejiang, Jlangxi.

Na początku czerwca 1919 r. do ruchu studentów przyłączyli się robotnicy podejmując akcje strajkowe. 5 czerwca strajk podjęli kupcy w Szanghaju, a za ich przykładem kupcy w innych portach handlowych. Do strajku przystąpili robotnicy szanghajskich zakładów mechanicznych, obróbki miedzi i cyny, a za ich przykładem strajk podjęli drukarze, włókniarze, kolejarze i tramwajarze. Ruch 4 Maja uaktywnił w jednolitym proteście różne warstwy społeczne, co ostatecznie doprowadziło do ustępstw rządu, który 9 czerwca 1919 r. usunął ze stanowiska Cao Rulina (1876-1966), Lu Zongyu (1876-1941) i Zhang Zongxiang (1876-1962) i wydał posłom w Paryżu zakaz podpisania traktatu pokojowego uwzględniającego niekorzystne dla Chin postanowienia ${ }^{178}$.

W literaturze przedmiotu wskazuje się na szerokie aktywne poparcie dla Ruchu 4 Maja w Chinach, na co wskazuje liczba aresztowanych studentów szacowana na około 1100 osób. Także poparcie robotników wydaje się znaczne, zwłaszcza w porównaniu do niewielkiego liczebnie chińskiego proletariatu.

177 Rana Mitter, op.cit., s. 23-25.

178 Yang Chunmei, The May Fourth Movement in Chinese History. To understand the May Fourth Movement, we must first understand its ideological roots (4.05.2019), https://www.sixthtone.com/news/1003904/the-mayfourth-movement-in-chinese-history [dostęp: 6.08.2019]. 
Tylko w Szanghaju strajk podjęło ok. 60 tys. robotników ${ }^{179}$, a w całych Chinach ok. 100 tys. ${ }^{180}$ Manifestacje i zamieszki trwały od 4 maja do 28 czerwca 1919 r. obejmując zasięgiem wszystkie najważniejsze miasta Chin. W antyjapońskich wystąpieniach uczestniczyli przedstawiciele wszystkich warstw miejskiej ludności: inteligencji, właścicieli przedsiębiorstw handlowo-produkcyjno-usługowych, rzemieślników i robotników ${ }^{181}$, co było pierwszym tego rodzaju przypadkiem w politycznej historii Chin, dając wyraz ogólnospołecznej świadomości politycznej kształtującej społeczeństwo obywatelskie. Do pełnego sukcesu zabrakło masowego poparcia chińskiego chłopstwa, co w ówczesnych warunkach przeważyło o niepowodzeniu ruchu, a przede wszystkim objęcia ruchu przewodnictwem organizacji zdolnej do usystematyzowania spontanicznego ruchu społecznego. Nawet Sun Yat-sen nie wiązał z Ruchem 4 Maja żadnych nadziei: projapońskie poglądy Suna oraz jego kompromisowa polityka w stosunku do obcych mocarstw stały w sprzeczności z wartościami antyjapońskimi, antyimperialistycznymi i antykolonialnymi tworzącymi podstawy ruchu. Nigdy nie był zwolennikiem wielkich, masowych ruchów, opowiadając się za lokalnymi powstaniami, organizowanymi przez starannie dobraną elitę. Uważał demonstrujących studentów za ludzi niedojrzałych, naiwnych o ograniczonej wiedzy na temat rewolucji. W pracy politycznej Sun Yat-sen skoncentrował się na pracy teoretycznej (Trzy zasady ludu) i powrotu na wielką scenę polityczną, powołując 10 października 1919 r. Chińską Partię Narodową (Zhongguo Guomindang), nawiązującej tradycją do partii powołanej w 1912 r. Statut Guomindangu,

179 J. Wasserstrom, Liu Xinyong, Student protest and student life: Shanghai, 1919-49, (1989), https://www.jstor.org/stable/4285735?seq=1\#page_scan_tab_contents [dostęp: 15.07.2019].

180 W.I. Głunin, op.cit., s. 86.

181 Ibidem, s. 85. 
przyjęty 9 listopada 1920 r. ujawniał wpływy partii leninowskiej oddając najważniejsze prerogatywy prezesowi-prezydentowi, zaś ideologię osadzono na Trzech zasadach ludu. Odchodząc od zachodniego modelu trójpodziału władzy, Sun upatrywał najwłaściwszy dla Chin system polityczny dzielący uprawnienia na pięć organów państwowych, tj. wykonawczą, ustawodawczą, sądowniczą, egzaminacyjną - zapewniającą dopływ należycie wydedukowanej, nowoczesnej biurokracji, oraz kontrolną (cenzura) - pełniącą rolę Izby Kontroli ${ }^{182}$.

Rysunek 2. Poster z 1976 r. przedstawiający Ruch 4 Maja - autor Liang Yulong

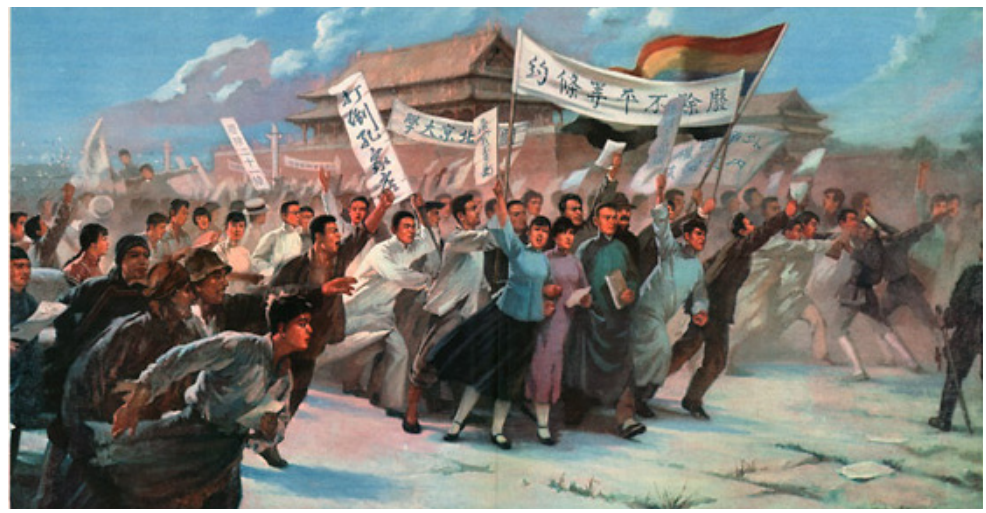

Źródło: https://chineseposters.net/posters/e15-575.php [dostęp: 15.09.2019].

$* * *$

Już dwa lata po wybuchu studenckiej rewolucji patriotyczny ruch odbudowy państwa i odnowy społeczeństwa, walki warlordowskim feudalizmem i imperialną dominacją zaczął stopniowo hamować. Ustępowała także powszechna krytyka konfucjanizmu. Wraz z wzmacnianiem pozycji Guomindangu w ruchu narodowym, pozycje umacniali zwolennicy konfucjańskiej ide-

182 B. Góralczyk, Sun Yat-sen..., op.cit., s. 105-106. 
ologii. Po przejęciu władzy przez Czang Kaj-szeka rozwijano ruch na rzecz kształtowania stosunków społecznych w Chinach nawiązujących do głównych kanonów konfucjańskich cnót, wzorców życia politycznego i społecznego, podejmując wysiłki włączenia do neokonfucjanizmu elementów zachodniego kapitalizmu. Odrodzenie narodu chińskiego utożsamiano z odrodzeniem konfucjańskim; „[...] w toku odnawiania konfucjanizmu nowoczesność i tradycja, nowe i stare, Chińczycy i ludzie Zachodu staną się holistyczną jednością i w ten sposób będą przyszłością Chin i narodu chińskiego"183. W literaturze przedmiotu wskazuje się, że ówczesny konserwatyzm i tradycjonalizm Partii Narodowej znajdował poparcie znacznej części chińskiego spoleczeństwa ${ }^{184}$, zatem reakcjonistyczne postawy wydają się mieć uzasadnienie w chińskiej rzeczywistości. Pomimo że wygasły ogniska wzniecone przez Ruch 4 Maja, to Ruch na rzecz Nowej Kultury pozostawił kolejnym pokoleniom spuściznę - podstawy społeczeństwa obywatelskiego, przejawiające się w wydarzeniach, jakie miały miejsce w kwietniu 1976 r. ${ }^{185} \mathrm{i}$ maju-czerwcu

183 Xinzhong Yao, Konfucjanizm. Wprowadzenie, tłum. Ju. Hunia, Kraków 2009, s. 268.

184 K. Gawlikowski, op.cit., s. 54.

1855 kwietnia 1976 r., podczas chińskiego święta zmarłych i składania kwiatów pod Pomnikiem Bohaterów Ludowych na Placu Tiananmen upamiętniających zmarłego w tym roku Zhou Enlaia (zm. 8.01.1976 r.), uroczystości zorganizowane przez studentów przerodziły się w demonstrację przeciwko radykałom. Uczestniczyło w niej ok. 200 tys. osób. Policja rozpędziła uczestników protestu, a propaganda zaklasyfikowała wydarzenia jako „kontrrewolucyjny incydent polityczny". Dwa lata później, już po śmierci Mao Zedonga i przejęciu władzy przez Deng Xiaopinga, ocenę tę zweryfikowano, określając wydarzenia mianem „działania rewolucyjnego”. Za sprowokowanie incydentu obciążono Deng Xiaopinga, którego kolejny raz pozbawiono wszystkich stanowisk. 7 kwietnia tego roku obowiązki premiera powierzono Hua Guofengowi, który objął także funkcję wiceprzewodniczącego KPCh z rekomendacji Mao Zedonga, a po jego śmierci 9.09.1976 r. - przewodniczącego KPCh. J. Bayer, W.J. Dziak, Historia polityczna Chin 1839-2014. Kronika najważniejszych wydarzeń..., s. 304. 


\section{$1989 \mathrm{r}^{186}$, a w czasach najnowszych w demokratycznych prote-}

18623 kwietnia 1989 r. przed oficjalnymi uroczystościami żałobnymi po śmierci Hu Yaobanga (zm. 15 kwietnia 1989 r.) na placu Tiananmen, grupa studentów rozbiła obóz wznosząc hasła z żądaniami przywrócenia przez partię dobrego imienia odsuniętego dwa lata wcześniej Hu. Spełnienie żądań oznaczałoby przyznanie się do błędu przez kierownictwo KPCh z Deng Xiaopingiem na czele. Równocześnie na pekińskim uniwersytecie pojawiły się dazibao (polityczne plakaty) wzywające do demokratyzacji kraju. 4 maja, w 70. Rocznicę Ruchu 4 Maja z 1919 r. odbył się marsz, w którym uczestniczyło ok. 50 tys. studentów i ok. 250 tys. mieszkańców Pekinu, wysuwających hasła demokratyzacji ustroju Chin: „Przecz z dyktatorskimi rządami”, „Precz ze skorumpowanym rządem”. Postulaty protestujących spotkały się ze zrozumieniem Zhao Ziyanga (1919-2005), ówczesnego sekretarza generalnego KPCh. Z żądaniem bezpardonowego rozprawienia się z demonstrantami występował Li Peng (1928-2019), pełniący obowiązki premiera rządu ChRL. W tym czasie manifestujący żądali ustąpienia Li Penga, eskalując hasła „Zwalczać biurokrację”, „Zwalczać korupcję”. Porównywano budzący się ruch z rewolucją francuską. W związku z wizytą Michaiła Gorbaczowa, chińskie władze nie podjęły wobec protestujących znaczących represji, jednak 9 maja Deng Xiaoping i „grupa starszych weteranów” podjęła decyzję o zdymisjonowaniu Zhao Zyianga. 17 maja podczas zwołanego ad hoc posiedzenia władz KPCh w rezydencji Deng Xiaopinga, podjęto decyzję o użyciu siły w celu rozwiązania demonstracji, której liczebność dochodziła już do ok. 1 mln protestujących. 18 maja Zhao Ziyang w imieniu najwyższych władz osobiście przeprosił demonstrantów za błędy popełnione przez rząd. 20 maja wprowadzono w Pekinie stan wyjątkowy, przy czym grupa generałów zakwestionowała decyzję o skierowaniu do Pekinu sił zbrojnych. 30 maja na Tiananmen pojawiła się kopia nowojorskiej Statui Wolności Bogini Demokracji, mająca symbolizować żądania protestujących. 3 czerwca do Pekinu wkroczyły oddziały 27. Armii ChALW, lecz próba pacyfikacji demonstrantów nie powiodła się. Następnego dnia wprowadzono kolejne oddziały wojska i sił bezpieczeństwa, które na bezpośredni rozkaz Deng Xiaopinga brutalnie spacyfikowały rewoltę, a przez kolejne miesiące prowadzono aresztowania osób uznanych za prowokatorów. J. Bayer, W.J. Dziak, Historia polityczna Chin 1839-2014. Kronika najważniejszych wydarzeń..., op.cit., s. 304, 370-377. Przez wiele lat opinia publiczna informowana była o liczbie ofiar po stronie demonstrantów szacowanej na maksymalnie 2,7 tys. W 2017 r. ujawniono raport ówczesnego brytyjskiego ambasadora Wielkiej Brytanii w Chinach Alana Donalda, w którym informuje o ponad 10 tys. ofiar, powołując się na „zaufane źródło”, którym miał być jeden z członków Rady Państwa. W raporcie ambasador informuje także o niezwykłej brutalności chińskich żołnierzy wobec protestujących, z których wielu zamordowano na miejscu. Szerzej: Odtajniony RAPORT ws. masakry na placu Tiananmen: 10 tysięcy ofiar. DRASTYCZNE OPISY, (23.12.2017 r.), https://wiadomosci.dziennik.pl/swiat/artykuly/565333,chiny-10-tys-ofiar- 
stach antyrządowych w latach2014 i 2019 w Hongkongu, w których nieomal całe społeczeństwo (na ulicę wyszło ok. $2 \mathrm{mln}$ mieszkańców) sprzeciwiło się decyzjom władz zamierzających wprowadzić w życie ustawę chińskiego rządu o ekstradycji do Chin kontynentalnych. Lokalne władze zarzucają manifestantom dążenie do „upadku Hongkongu”, czym usprawiedliwiają użycie uzbrojonych jednostek policji, które brutalnie rozpędzają protestantów. Działania władz wspiera chiński aparat propagandowy, eskalujący wiadomości o rzekomym wspieraniu demonstrantów przez „zachodnich agentów”187.

Fotografia 1. Fotografia opublikowana na całym świecie - protestujący student na placu Tiananmen w Pekinie

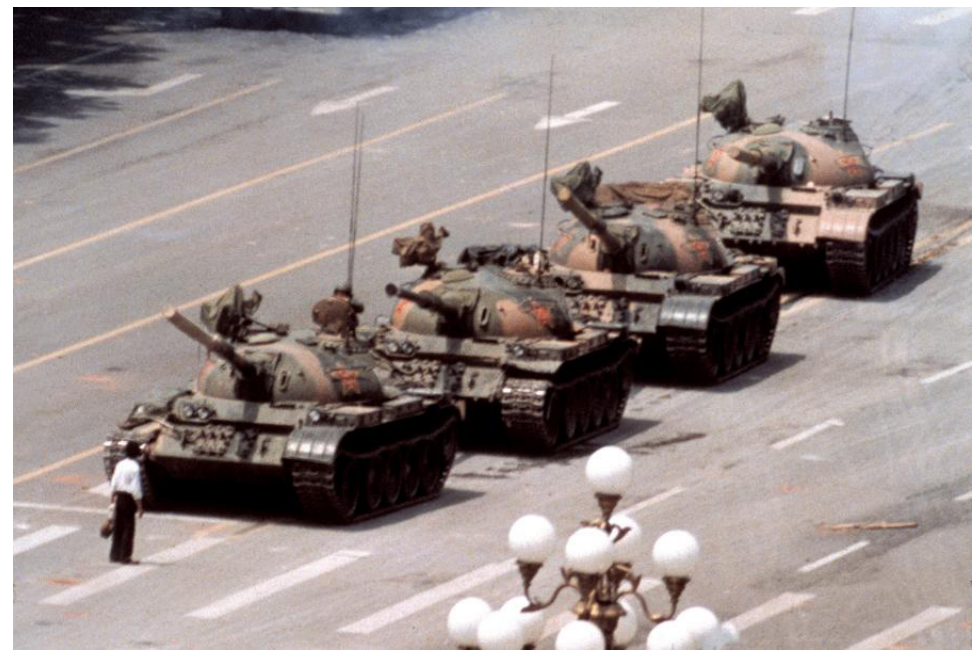

Źródło: https://wiadomosci.dziennik.pl/swiat/zdjecia/galeria/565333,1,chiny-10-tys-ofiar-na-placu-tiananmen-wedlug-odtajnionego-dokumentu.html [dostęp: 4.06.2019].

-na-placu-tiananmen-wedlug-odtajnionego-dokumentu.html [dostęp: 4.06.2019].

187 Wilfred Chan, Demokracja i życie ludzi w Hongkongu? Bogowie globalizacji maja to w nosie, tłum. M. Badziak (21.08.2019 r.), https://krytykapolityczna.pl/hong-kong-protesty-2019/ [dostęp: 17.09.2019]. 
Do dorobku Ruchu 4 Maja odwoływał się Mao Zedong, wszczynając w 1966 r. rewolucję kulturalną w Chinach, uzasadnianą następująco: „po zakończeniu socjalistycznego przekształcenia własności środków produkcji powinna nadejść nowa rewolucja, która raz na zawsze usunie pozostałości kultury burżuazyjnej - od prywatnych myśli po prywatne rynki. Tak samo jak przejście od kapitalizmu do socjalizmu wymagało rewolucji, również przejście od socjalizmu do komunizmu wiązało się z rewolucją", której twarzą i najważniejszym mentorem miał być tylko Mao i jego marksistowsko-leninowsko-maoistowska ideologia ${ }^{188}$.

Wobec osiągnięć Ruchu 4 Maja nie pozostaje bierna obecna władza ChRL. Na kilka dni przed obchodami setnej rocznicy ruchu, obecny przywódca Chin, Przewodniczący ChRL i sekretarz generalny KPCh Xi Jinping podczas spotkania z młodymi aktywistami partii wskazał, że „młodzi ludzie powinni być wdzięczni partii, krajowi i społeczeństwu, zaś patriotyzm jest obowiązkiem", przy czym wyjaśniał, iż obecnie patriotyzm to oddanie socjalizmowi, miłość do kraju oraz partii ${ }^{189}$. Przywódca Chin próbuje kształtować postawy chińskiej młodzieży wykorzystując do tego cały aparat biurokratyczno-propagandowo-oświatowy, uzasadniający: „Żeby kontynuować korzystanie w pełni z ducha Ruchu 4 Maja i by pomóc przedsięwziąć wielkie zadanie odbudowy narodu, [młodzież] musi dogłębnie rozumieć zasadę Sześciu Nadziei opisaną przez przewodniczącego Xi Jinpinga”. Do sześciu zasad należą: formowanie dalekosiężnych ideałów; gorliwa miłość do ojczyzny; branie odpowie-

188 Dzieje Chin w okresie rewolucji kulturalnej przedstawiono w monografii F. Dikottera, Rewolucja kulturalna. Historia narodu 1962-1976, Wołowiec 2018.

189 Jiayang Fan, Xi Jinping Tries to Crash the May Fourth Movement's Centenary (4.05.2019 r.), https://www.newyorker.com/news/daily-comment/ xi-jinping-tries-to-crash-the-may-fourth-movements-centenary [dostęp: 19.07.2019]. 
dzialności w swoim wieku; gotowość do walki; doskonalenie się oraz zdolność do doskonalenia moralności ${ }^{190}$. Jednym słowem nic nie może się dziać bez woli i zgody Xi Jinpinga. W tym kontekście protesty w Hongkongu zdają się nie mieć szans w zderzeniu z radykalizmem władz, które z pewnością nie zawahają się użyć nieproporcjonalnych sił, na co wskazują doniesienia o zwiększaniu liczby wojska w Hongkongu ${ }^{191}$, a zwłaszcza zapowiedzi władz o konieczności „przyjęcia twardszej linii, by przywrócić porządek" ${ }^{192}$. Po stu latach od Ruchu 4 Maja władza w Chinach ponownie występuje przeciwko obywatelom, podejmuje radykalne działania przeciwko apologetom demokracji oraz swobód i praw obywatelskich.

\section{Bibliografia}

Bayer J., Dziak W.J., Historia polityczna Chin 1839-2014. Konspekt analityczny, Warszawa 2016.

Bayer J., Dziak W.J., Historia polityczna Chin 1839-2014. Kronika najważniejszych wydarzeń, Warszawa 2015.

Bendiner E., Czas aniotów. Tragikomiczna historia Ligi Narodów, tłum. J. Okopień, Warszawa 1981.

Burlingas I., Stosunki międzynarodowe na Dalekim Wschodzie w latach 1904-1914, [w:] Historia polityczna Dalekiego Wschodu od końca XVI w do 1945 r., red. J. Żukow, M. Sładkowski, A. Dubinski, tłum. H. Jaźwińska, Warszawa 1981.

190 R. Tomański, Sto lat temu Chiny mogty stać się całkowicie innym państwem. I świat nie bytby taki sam (4.05.2019 r.), https://businessinsider. com.pl/wiadomosci/setna-rocznica-ruchu-4-maja-wybiorcza-pamiec-o-studenckich-protestach/8rrpqtp [dostęp: 19.07.2019].

191 Chińska armia ostrzega protestujących (7.10.2019 r.), https://www. tvn24.pl/wiadomosci-ze-swiata,2/protesty-w-hongkongu-garnizon-chinskiej-armii-ostrzega-demonstrantow,975233.html [dostęp: 10.10.2019].

192 Xi Jinping zabrat głos w sprawie niepokojów w Hongkongu (4.11.2019 r.), https://www.tvn24.pl/protesty-w-hongkongu-xi-jinping-wezwal-do-zakonczenia-przemocy-i-chaosu,982882,s.html [dostęp: 8.11.2019]. 
Chińska armia ostrzega protestujących (7.10.2019 r.), https:// www.tvn24.pl/wiadomosci-ze-swiata,2/protesty-w-hongkongu-garnizon-chinskiej-armii-ostrzega-demonstrantow,975233.html [dostęp: 10.10.2019].

Chwostow W.M., Walka dyplomatyczna w okresie pierwszej wojny światowej, [w:] Historia dyplomacji 1914-1939, t. III, red. A.A. Gromyko et al., Warszawa 1973.

Dikotter F., Rewolucja kulturalna. Historia narodu 1962-1976, Wołowiec 2018.

Dmochowski T., Interwencja mocarstw na Syberii i Dalekim Wschodzie (1918-1922), Toruń 2000.

Dmochowski T., Rewolucja 1917 r. w strefie wywtaszczonej kolei wschodniochińskiej w Harbinie, "Gdańskie Studia Azji Wschodniej" 2015, nr 8.

Epstein I., Rewolucja w Chinach trwa, Warszawa 1949.

Fairbank J.K., Historia Chin. Nowe spokrzenie, tłum. T. Lechowska, Z. Słupski, Warszawa-Gdańsk 2003.

Fenby J., Chiny. Upadek $i$ narodziny wielkiej potęgi, tłum. J. Wąsiński, J. Wołk-Łaniewski, Kraków 2009.

Gacek Ł., Rola konfucjanizmu w kształtowaniu ideologii państwowej w Chinach $w$ XX wieku, „Krakowskie Studia Międzynarodowe" 2015, nr 3.

Gawlikowski Kr., Nowa batalia o Konfucjusza, Warszawa 1976. Głunin W.I., Przypływ ruchu narodowowyzwoleńczego w Chinach (1917-1924), [w:] Najnowsza historia Chin (1917-1976), red. G.W. Astafiew, W.N. Nikiforow, M.I. Sładkowskij, Warszawa 1976.

Góralczyk B., Pekińska wiosna 1989. Poczatki ruchu demokratycznego w Chinach, Warszawa 1999.

Góralczyk B., Rewolucja Xinhai w chińskich dziejach, „Azja-Pacyfik" 2011, t. XIV.

Góralczyk B., Sun Yat-sen. Misjonarz rewolucji, Warszawa 2013. 
Góralczyk Z., Komunistyczna Partia Chin a Stany Zjednoczone (lipiec 1921-czerwiec 1950), Warszawa 1981.

Halik T., Powstanie „Yihetuan” (1898-1901), [w:] Nowożytna historia Chin, red. R. Sławiński, Kraków 2005.

Halik T., Reformatorzy i rewolucjoniści, [w:] Nowożytna historia Chin, red. R. Sławiński, Kraków 2005.

Halik T., Stosunki Chin z obcymi mocarstwami od połowy $X I X$ w. do lat 30. XX w., [w:] Nowożytna historia Chin, red. R. Sławiński, Kraków 2005.

Haapanen J., Adaptation to World Trends. A Rereading of the May Fourth Movement Radicalization, Juvaskyla 2013.

Hayford Charles W., Literacy Movemoment in Modern China (1987), https://www.researchgate.net/publication/300450509_ Literacy_Movements_in_Modern_China.

https://chineseposters.net/posters/e15-575.php. https://pl.wikipedia.org/wiki/Kinmochi_Saionji. https://www.britannica.com/biography/Ronglu.

Jefimow G., Wielka Socjalistyczna Rewolucja Październikowa a Daleki Wschód. Konferencja waszyngtońska, [w:] Historia polityczna Dalekiego Wschodu od końca XVI w do 1945 r., red. J. Żukow, M. Sładkowski, A. Dubinski, tłum. H. Jaźwińska, Warszawa 1981.

Jefimow G., Zarys nowożytnej $i$ wspótczesnej historii Chin, tłum. M. Derenicz, Warszawa 1953.

Jiayang Fan, Xi Jinping Tries to Crash the May Fourth Movement's Centenary (4.05.2019 r.), https://www.newyorker. $\mathrm{com} /$ news/daily-comment/xi-jinping-tries-to-crash-the-may-fourth-movements-centenary.

Jones Steve, The Fourteen Points of Woodrow Wilson's Plan for Peace (7.07.2019), https://www.thoughtco.com/the-fourteen-points-3310117.

Kissinger H., Dyplomacja, Warszawa 2002.

Koetse M., Gendered Nationalism and May Fourth: China's 
„New Woman” (8.12.2012), https://www.manyakoetse.com/ gendered-nationalism-and-may-fourth-chinas-new-woman/. Konior Jan SJ, Historia Kościoła w Chinach. Wyzwania, obawy i nadzieje (od nestorianizmu do czasów współczesnych), Kraków 2019.

Król A.I., Chiny w latach 1898-1937 - między artystyczna tradycją a sztuką Zachodu, Warszawa-Toruń 2016.

Kukowski M., Proces przyjęcia i odrzucenia japońskiego wzoru przez Chiny. Od końca XIX wieku do 1937 roku, https:// mysl.lazarski.pl/fileadmin/user_upload/dokumenty/czasopisma/mysl-ekonomiczna-polityczna/2014/MEiP_1_7_ 2014_Kukowski.pdf.

Levy J.S., The first Word War: causes, concequences, and controversies, https://fas-polisci.rutgers.edu.

Li Dazhao, https://pl.wikipedia.org/wiki/Li_Dazhao.

Ławacz M., Sun Yat-sen - życie i działalność, [w:] Sun Yatsesn, Trzy zasady ludu, tłum. A. Łobacz, Warszawa 1914.

Łukasik P., Impuls Wilsona - Stany Zjednoczone w I wojnie światowej, „Ante Portas - Studia nad Bezpieczeństwem” 2015, nr 1.

Malicka A. (red.), Najnowsza historia Chin, tłum. M. Derenicz, Warszawa 1954.

MacMillan M., Paryż 1919. Sześć miesięcy, które zmienity świat: konferencja pokojowa w Paryżu w 1919 roku i próba zakończenia wojny, Oświęcim 2018.

Marshall G.C., Memoirs of My Services in the World War 1917-1918, Boston 1976.

Materski W., Bolszewicy i samuraje. Walka dyplomatyczna i zbrojna o rosyjski Daleki Wschód (1917-1925), Warszawa 1990.

Mencel M.T., Chińska Republika Ludowa jako współczesny podmiot środowiska międzynarodowego, t. I: Uwarunkowania, Toruń 2016. 
Mencel M.T., Chińska Republika Ludowa jako wspótczesny podmiot środowiska międzynarodowego, t. II: Wektory, Toruń 2016.

Mencel M.T., Chińska Republika Ludowa jako wspótczesny podmiot środowiska międzynarodowego, t. III: Rozważania o rzeczywistości, Toruń 2016.

Mencel M., Kobieta w Chinach: kulturowa przeszłość i teraźniejszość, [w:] Kobiety w życiu kulturowym Polski i świata, red. A. Chodubski, A. Frączek, B. Słobodzian, Gdańsk 2012. Mencel M.T., Wiejski charakter chińskiego społeczeństwa, [w:] M.T. Mencel, Chińska Republika Ludowa jako wspótczesny podmiot środowiska międzynarodowego, t. III: Rozważania o rzeczywistości, Toruń 2016.

Mierzejewski D., Wyzwania chińskiej dyplomacji u progu ery republikańskiej, „Azja-Pacyfik” 2011, t. XIV.

Minc I.I., Zwycięstwo koalicji nad Niemcami i ich sprzymierzeńcami, [w:] Historia dyplomacji 1914-1939, t. III, red. A.A. Gromyko et al., Warszawa 1973.

Mitter R., Gorzka rewolucja. Zmagania Chin z nowoczesnym światem, tłum. T. Białogórska, Warszawa 2008.

Morton W.S, Lewis Ch.M., Chiny. Historia i kultura, tłum. B.S. Zemanek, Kraków2007.

Odtajniony RAPORT ws. masakry na placu Tiananmen: 10 tysięcy ofiar. DRASTYCZNE OPISY (23.12.2017 r.), https:// wiadomosci.dziennik.pl/swiat/artykuly/565333, chiny10-tys-ofiar-na-placu-tiananmen-wedlug-odtajnionego-dokumentu.html.

Osterhammel J., British business ich China, 1860s-1950s, Cambridge 1989.

Pajor J., Chiny w polityce zagranicznej Stanów Zjednoczonych w latach 1911-1918, Łódź 2019.

Pietraszak M., Dacyszen W., Regionalny aspekt historii stosunków rosyjsko-chińskich, Łódź 2012. 
Plesiewicz-Świerczyńska I., Wykładnie ideologiczne stosunków japońsko-amerykańskich $w$ latach 1853-1941 oraz ich implementacja polityczna, praca doktorska, Uniwersytet Łódzki Wydział Studiów Międzynarodowych i Politologicznych, Łódź 2017, https://kipdf.com/queue/uniwersytet-odzki-wydzia-studiow-midzynarodowych-i-politologicznych-izabela-ples_5b35197b097c47886d8b4b18.html.

Polit J., Japonia wobec rewolucji bolszewickiej w Rosji, 1917-1922, „Dzieje Najnowsze” 2007, r. XLIX, nr 4.

Polit J., Mocarstwa wobec rewolucji Xinhai, „Azja-Pacyfik” 2011, t. XIV.

Polit J., Wojny chińskich warlordów 1916-1928, Zabrze-Tarnowskie Góry 2017.

Rodziński W., Chiny w ogniu. Rewolucja w latach 1925-1927, Wrocław-Warszawa-Kraków-Gdańsk-Łódź 1983.

Rodziński W., Historia Chin, Wrocław-Warszawa-Kraków 1992.

Rojek W., Spory o wtadanie morzem. Polityczno-dyplomatyczne aspekty zbrojeń morskich $w$ okresie międzywojennym 1919-1939, Kraków 1994.

Saveliev I.R., Pestushko Yuri S., Dangerous Rapprochement. Russia and Japan in the First World War, 1914-1916, https://www.semanticscholar.org/paper/Dangerous-Rapprochement-\%3A-Russia-and-Japan-in-the-Saveliev-Pestushko/9ce90eb43425cdf9c705a555f4e9db2f32d571e2.

Sierpowski S., Narodziny Ligi Narodów. Powstanie, organizacja i zasady działania, Poznań 1984.

Skřivan A. Jr., Skřivan A. Sr., Great Powers and the Sino-Japanese War 1894-1895, http://cejsh.icm.edu.pl/cejsh/contributor/9166dddb9ad73f6de6e47e7d2f444b0d.

Sładkowski M., Chiny i Japonia, Warszawa 1975.

Sładkowski M., Pierwsza wojna światowa i Daleki Wschód (1914-1918), [w:] Historia polityczna Dalekiego Wschodu 
od końca XVI w do 1945 r., red. J. Żukow, M. Sładkowski, A. Dubinski, tłum. H. Jaźwińska, Warszawa 1981.

Sławiński R., „Nowy” konfucjanizm w krajach Azji Wschodniej, „Krakowskie Studia Międzynarodowe” 2010, nr 1.

Sławiński R., Yuan Shikai i rzady militarystów. Wyprawa pótnocna i zjednoczenie kraju, [w:] Nowożytna historia Chin, red. R. Sławiński, Kraków 2005.

Sokala P., Liga Narodów - globalny diler zasad i wyjatków? Historyczne znaczenie organizacji w perspektywie historii Chin, [w:] Liga narodów wybranych, red. M.F. Gawrycki, A. Bógdał-Brzezińska, Warszawa 2010.

Sun Yat-sen, Trzy zasady ludu, red. K. Gawlikowski, M. Ławacz, tłum. A. Łobacz, Warszawa 2014.

Tomański R., Sto lat temu Chiny mogty stać się catkowicie innym państwem. I świat nie bytby taki sam (4.05.2019 r.), https://businessinsider.com.pl/wiadomosci/setna-rocznica-ruchu-4-maja-wybiorcza-pamiec-o-studenckich-protestach/8rrpqtp.

Treaty of Shimonoseki, http://www.taiwandocuments.org/shimonoseki01.htm.

Tychwinski S.L. (red.), Historia nowożytna Chin, tłum. M. Wolska, Warszawa 1979.

Wasserstrom J., Liu Xinyong, Student protest and student life: Shanghai, 1919-49 (1989), https://www.jstor.org/stable/4285735?seq=1\#page_scan_tab_contents.

Robert W., Woodrow Wilson's Fourteen Points (29.03.2019), https://www.thoughtco.com/woodrow-wilsons-fourteen- points-1222054.

Woodrow W., Kształtowanie losów świata. Pamiętniki i dokumenty, t. 1, tłum. A. Tretiak, Warszawa 1924.

Xi Jinping zabrat głos w sprawie niepokojów w Hongkongu, (4.11.2019 r.), https://www.tvn24.pl/protesty-w-hongkon- 
gu-xi-jinping-wezwal-do-zakonczenia-przemocy-i-chaosu,982882,s.html.

Xinzhong Yao, Konfucjanizm. Wprowadzenie, tłum. J. Hunia, Kraków 2009.

Yang Chunmei, The May Fourth Movement in Chinese History. To understand the May Fourth Movement, we must first understand its ideological roots (4.05.2019), https://www. sixthtone.com/news/1003904/the-may-fourth-movement-in-chinese-history.

\begin{abstract}
Abstrakt
100-letnia rocznica tych wydarzeń daje asumpt do podjęcia rozważań mających na celu ustalenie właściwych przyczyn wybuchu Ruchu 4 Maja i jego wpływu na kształtowanie wewnętrznych stosunków społecznych i zmiany zachodzące w chińskiej przestrzeni społeczno-politycznej. Rozważania przedstawione w niniejszym wykładzie skoncentrowano głównie na syntetycznym ujęciu problematyki zmian zachodzących w środowisku międzynarodowym, zwłaszcza polityki mocarstw wobec Chin oraz zjawiskach zachodzących w chińskim społeczeństwie, których Ruch 4 Maja był konsekwencją. Obszar analizy wyznaczają pola obejmujące ówczesne relacje międzynarodowe Chin, stosunki wewnętrzne i przemiany społeczne zachodzące w Chinach po obaleniu autorytaryzmu feudalnego, uwarunkowania gospodarcze Chin na przełomie XIX i XX w., a także wzrost społecznej świadomości politycznej, społecznego zainteresowania socjalizmem i komunizmem, wzrastanie narodowego nacjonalizmu oraz tworzenie zrębów społeczeństwa obywatelskiego, odrzucenie tradycji konfucjańskiej i powrót do konfucjańskich wzorców.
\end{abstract}

Słowa kluczowe: Chiny, Ruch 4 Maja, Ruch na rzecz Nowej Kultury, rewolucja Xinhai, rewolucja październikowa, konferencja pokojowa w Paryżu, komunizm, społeczeństwo obywatelskie, konfucjanizm, nacjonalizm, emancypacja, feminizm 


\begin{abstract}
The 100-year anniversary of these events gives rise to considerations aimed at determining the proper causes of the outbreak of the May 4 Movement and its impact on shaping internal social relations and changes occurring in the social and political space in China. The considerations presented in this lecture focused mainly on a synthetic approach to the issue of changes occurring in the international environment, especially the policy of the powers towards China and phenomena observed in Chinese society, resulting in the May 4 Movement. The area of analysis is marked by fields covering the then international relations of China, internal relations and social changes occurring in China after the overthrow of feudal authoritarianism, economic conditions of China at the turn of the $19^{\text {th }}$ and the $20^{\text {th }}$ centuries, as well as the increase of social political awareness, social interest in socialism and communism, the growth of national nationalism and building the foundations of civil society, rejecting Confucian tradition and returning to Confucian examples.
\end{abstract}

Keywords: China, May 4 Movement, Movement for New Culture, Xinhai Revolution, October Revolution, Peaceful Conference in Paris, communism, civil society, Confucianism, nationalism, emancipation, feminism 